\title{
A COMParative Grammar OF JUST WAR: CONTRASTING AUguSTINIAN CHRISTIAN AND VEDIC HINDU WORLDVIEWS
}

\author{
by \\ Keith J. Gomes \\ A thesis submitted to the Faculty of Graduate and Postdoctoral Affairs \\ in partial fulfilment of the requirements for the degree of
}

\author{
Doctor of Philosophy \\ in \\ Political Science
}

Carleton University

Ottawa, Ontario

(C) 2014

Keith J. Gomes 


\begin{abstract}
This dissertation examines some of the metaphysical assumptions that inform how people think about warfare. In the Christian West, rules on warfare developed into the just war doctrine, and St. Augustine is often acknowledged as the person who introduced these ideas to Western philosophy. However, all of Augustine's thought is rooted in his understanding of reality through the lens of his Christian faith - a fifth century Roman Catholic worldview (Weltanschauung). As a result, current norms in international law on warfare (such as $R 2 P$ ) also reflect these Christian metaphysical assumptions. This dissertation examines not only how Augustinian metaphysical assumptions impact our ideas of warfare in international law but also how these ideas would change if one did not subscribe to this Augustinian worldview. Since Hinduism is often associated with nonviolence, a Hindu worldview is examined to determine what kind of just war theory, if any, would arise. First, the link between Christian philosophy and modern international law is outlined, tracing the development of thought from Augustine to modern times by examining Bible verses and writings by political theorists and others on just war theory and Christian theology. Then, Christian metaphysical assumptions are examined in order to determine how these assumptions influence Christian ideas of warfare. Psychological impacts of Christian assumptions are also looked at through the lens of Girardian analysis. In the second half, Hindu political writings, scriptures and religious texts as well as books about Hinduism are examined to discover how Hindus have thought about war. Hindu metaphysical assumptions are examined and inferences are made to show the connection between these assumptions and Hindu ideas of non-violence. The following aspects are examined in order to see how they generate ideas about war: ontology, creation myths and conceptions about God, the afterlife and end of the world, axiology, praxeology and epistemology. The research shows that Christian metaphysical assumptions (which many Christians now consider outdated) continue to influence modern ideas about war idea while Hindu metaphysical assumptions tend to influence the kind of non-aggression associated with Gandhi.
\end{abstract}




\section{ACKNOWLEDGMENTS}

I would like to thank my adviser, Peter Emberley, for piquing my interest in Political Theory and the connection between religion and political science. Also, many thanks to Noel Salmond for his extensive comments, insightful feedback and meticulous editing. I am also grateful to Farhang Rajaee and Rajesh Shukla, who at short notice graciously agreed to be part of my committee and provided valuable feedback and suggestions to further focus my research. Finally, my sincere gratitude to Marc Tyrrell for his interest in this dissertation and for being invaluable in the publishing of a paper which would later form the basis of the first chapter. The numerous hours of conversation, feedback and constant efforts to get me to think more clearly about aspects such as methodology and application of this research were instrumental in completing this dissertation.

Also a big thank-you goes out to everyone who kept me sane throughout this programme. Amongst others, the large number people who have become part of my closest circle of friends since starting this programme who are connected to the Christ Church Cathedral Choir of Men and Boys. Thanks to Matthew Larkin, I was able to enjoy many wonderful musical opportunities that were a welcome distraction from school. Choir trips to the UK made it possible for me to find some interesting books (like Beier's A Violent GodImage: An Introduction to the Work of Eugen Drewermann) while searching through the shelves at the Cambridge University bookstore, and enabled me to be able to proofread much of the dissertation in Edinburgh and London. A special mention to the clergy at Christ Church Cathedral, Ottawa, namely, Shane Parker (who read the first version of Chapter 1), Dawna Wall, Catherine Ascah and Robert Graham, who provided me with many opportunities for discussions on religion and my thesis. Finally, special thanks to Catharine Marceau for her comments and for being so willing to help with final proofreading, and to Larry Kempffer for lending me some books on the Christian just war.

And lastly, to my parents, for their love and support, and especially their financial sacrifices that allowed me to continue with my education to this extent.

This dissertation is dedicated to all my friends and acquaintances, past, present, and future, whose lives have been irrevocably changed by the horror of war. Even at its best, war can result in loss of country or national identity, reluctance to return to one's homeland, cynicism in the unity of people, and the belief in an uncertain future. At its worst, war causes unimaginable bodily harm, stress and mental trauma, the loss of or separation from friends and loved ones, the loss of income and hard-earned savings, and the loss of a life once cherished. 


\section{CONTENTS}

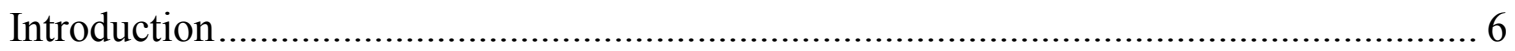

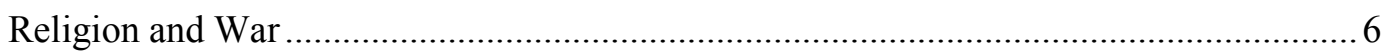

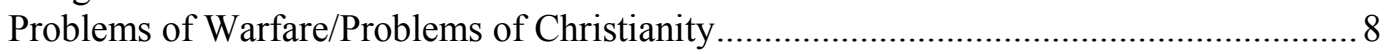

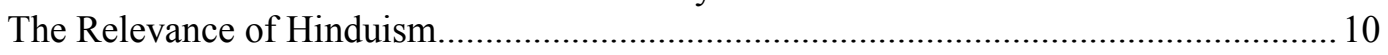

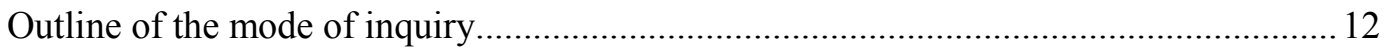

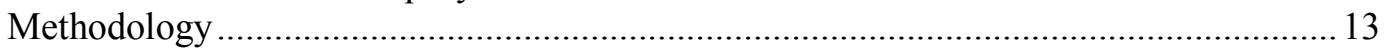

The Connection between Religion and International Relations..................................... 15

Embracing International Political Theology (IPT) ....................................................... 16

Chapter 1 - A Genealogy of the Just War: A Survey of Christian Political Thought on the

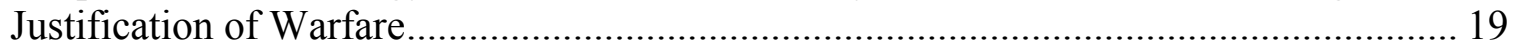

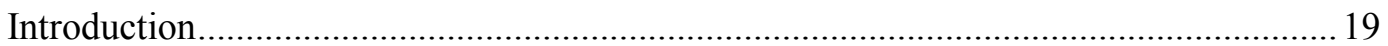

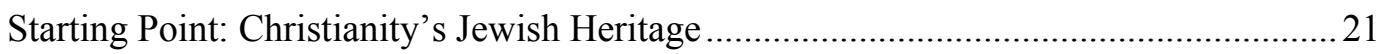

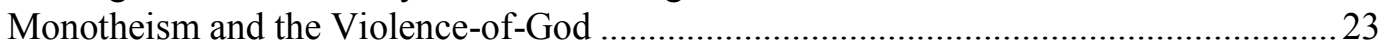

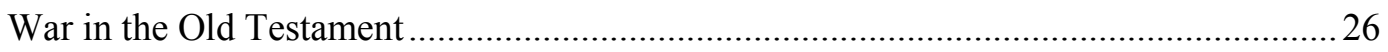

Explanations for the Old Testament Images of War....................................................28

The New Testament and War: From Pacifism to Just War.............................................. 30

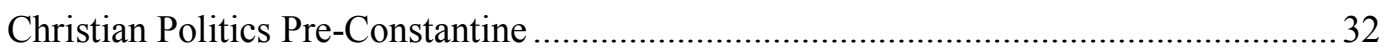

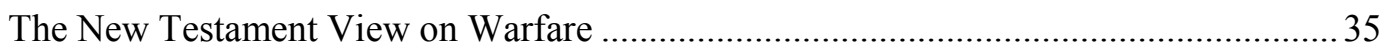

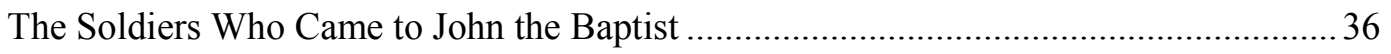

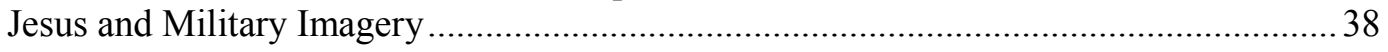

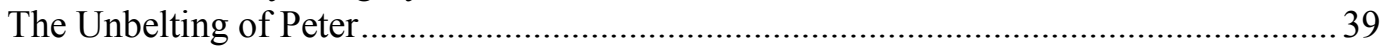

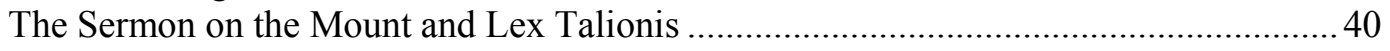

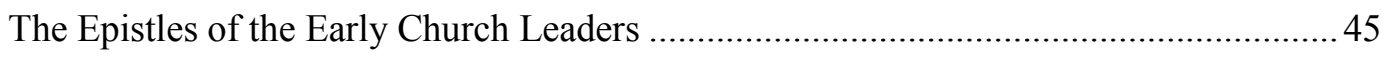

Pacifism or Just War? The Choice of Early Church Leaders............................................ 48

St. Ambrose of Milan - the Precursor to Augustine ....................................................... 51

Christian Attitudes towards War during the time of Augustine .........................................54

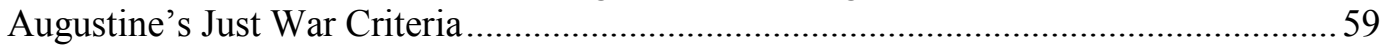

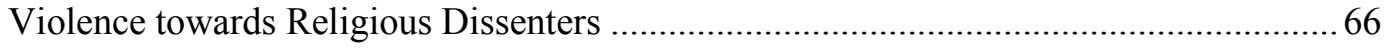

Christianity and the Law: Christian Influences on the Law...........................................67

Thomas Aquinas: Creating a Manual of Christian Theology ……................................... 71

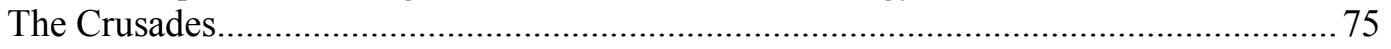

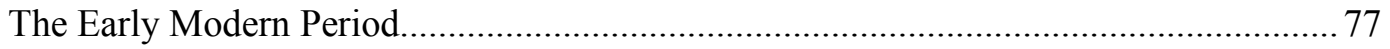

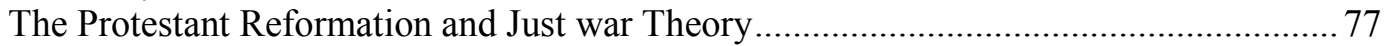

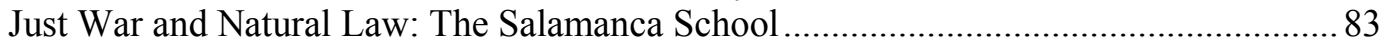

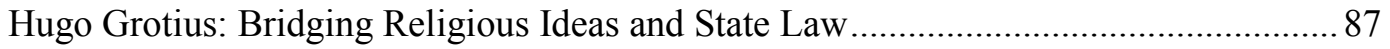

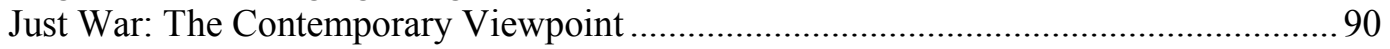

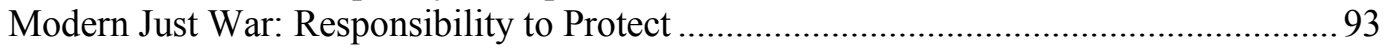

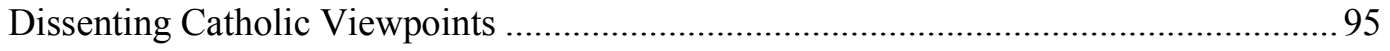

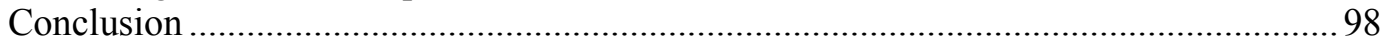


Chapter 2 - The Theological Basis for the Christian Just War...................................... 100

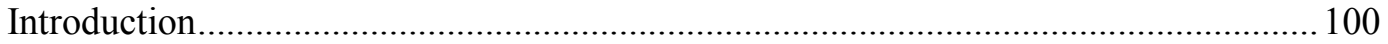

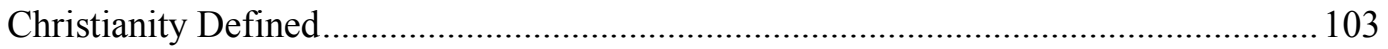

The Beginning: The Extent of the Augustinian Contribution ........................................... 105

Augustine on War and Peace ................................................................................... 106

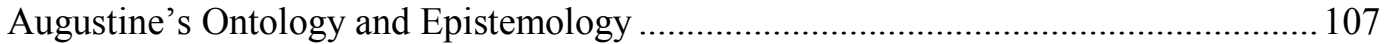

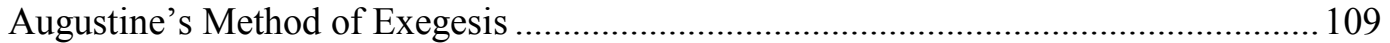

Creation, Human Nature, Politics and Augustine's Attitude to War ................................111

The Failures of Augustine............................................................................................ 118

Violence Unveiled: Counteracting Victimhood as a Cause of War.................................124

The West, Victimhood and Failure of the Scapegoat Mechanism...................................127

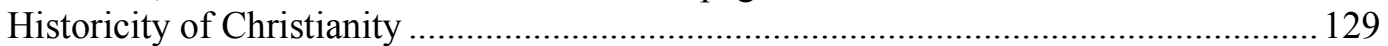

Bailie's Look at the Hebrew Bible - The Fall and Mimetic Desire …………………..... 130

The Evolution of the Anti-Sacrificial Impulse: Jesus and the New Anthropos ...............132

Eugen Drewermann and the Role of Fear in Christianity ..............................................136

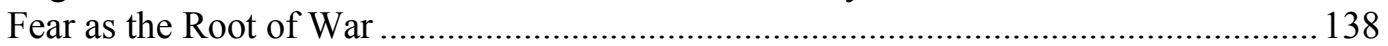

The Fall: The Origin of a Violent God-Image ........................................................... 139

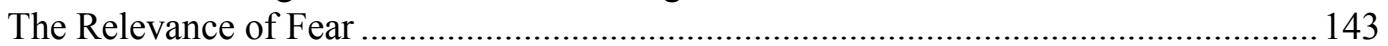

Other Psychological Motivations for War: Gender and Sexuality.................................... 146

The Consequences of Fear in Fostering War ................................................................. 148

Anthropomorphism, One Sided Rationalism and Radical Anthropocentrism ................. 149

Hostility Toward Myths, the War on Nature, Atheism, and the Secularizing Effects of

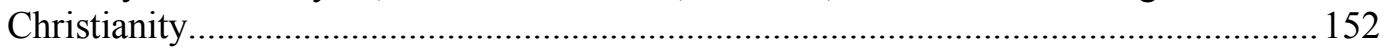

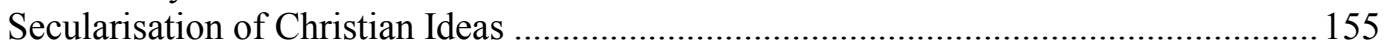

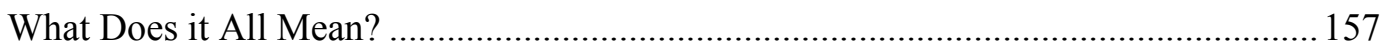

Chapter 3 - Sanātana Dharma and War: Examining the Hindu Political Thought on Warfare

The Starting Point of Hindu Political Ideas - From the Vedic to the Upanișadic Periods

The Hindu Practice of War

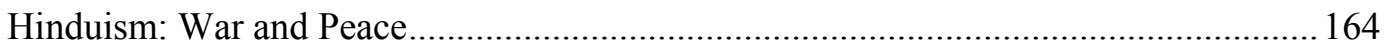

Kauṭilya's Arthaśāstra and the Mauryan Empire ........................................................... 167

The End of the Mauryan Empire and the Laws of Manu............................................... 172

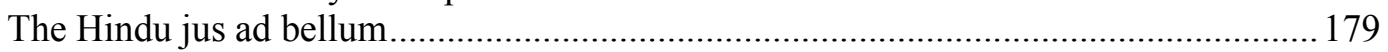

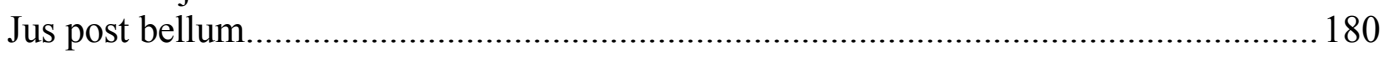

War and Violence as an Instrument of the State: Hindu Political Works After the

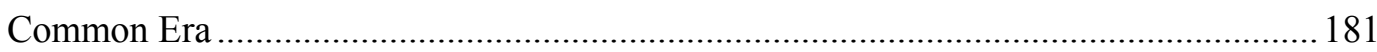

Hindu Political Theory after the Islamic Invasion ........................................................ 186

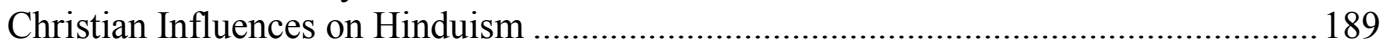

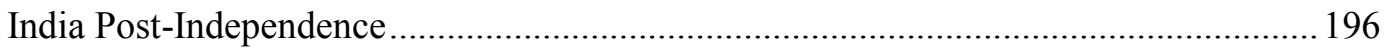

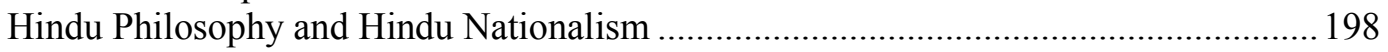

Militant Hinduism: B.G. Tilak .............................................................................. 200

Summary of Hindu and Christian Political Thought ……………………………….....2203

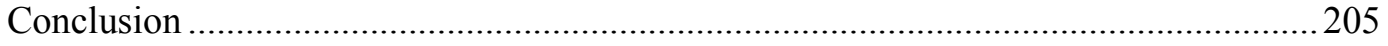


Chapter 4 - Hindu Theology, the Bhagavad Gītā and Warfare ....................................... 208

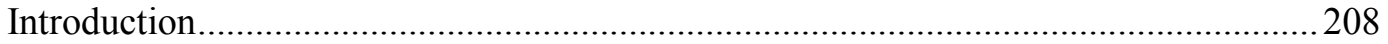

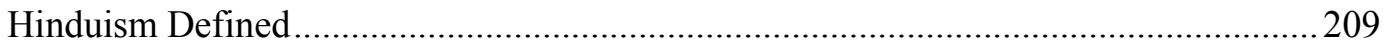

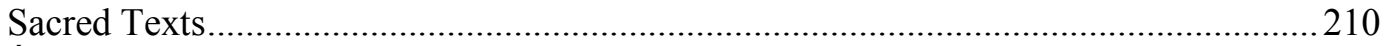

Śruti (Heard or Revealed) Texts: The Vedas and The Upanișads ....................................2210

Smṛti (remembered) Texts: Mythological Epics and the Bhagavad Gìtā ........................214

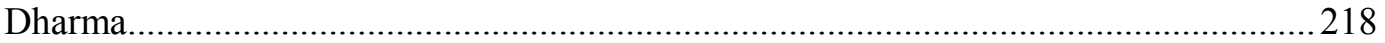

The Relationship between God and Man: Brahman and Ätman....................................2219

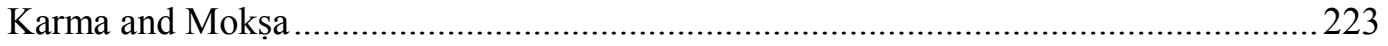

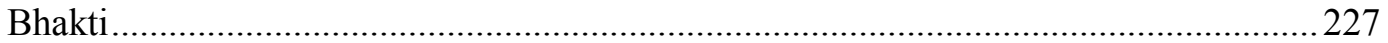

Philosophy and Theology: Indian v. Western ...........................................................228

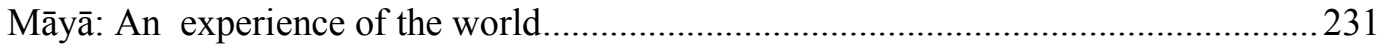

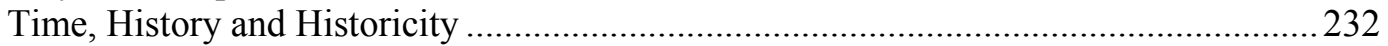

Systematic Hindu Philosophies (Darśanas): Different Theologies, Different Ontologies,

Different Epistemologies .....................................................................................236

Advaita Vedānta: Modern Hindu Philosophy .............................................................2238

Background story of Bhagavad Gītā ........................................................................224

A Synopsis of the Main Plot of Mahābhārata ...............................................................224

The Bhagavad Gītā and Kụṣna's Sermon to the Warrior ..................................................24

Motiveless Action: The Crux of the Bhagavad Gītā ......................................................2249

Yoga - the Path of Motiveless Action …………………………………………......225

Kṛ̣na Exemplifying the Act of a Perfect Sacrifice vis-à-vis Soldiering ……………......225

An Allegorical Interpretation of the Bhagavad Gītā ....................................................224

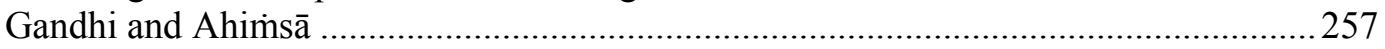

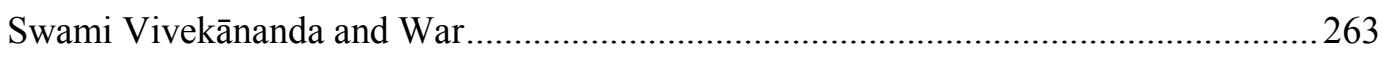

Swami Parhamhansa Yogānanda and Humanitarian Intervention..................................2.265

Swami Prabhavānanda: A Vedantic Understanding of the Sermon on the Mount .........266

Violence, Sacrifice and Ritual Sacrifice: Applying Girardian Insight to Hindu Beliefs 272

Violence as an Instrument of the State ......................................................................22

Hinduism and the Victim: Karma as an Expression of Violence ....................................22

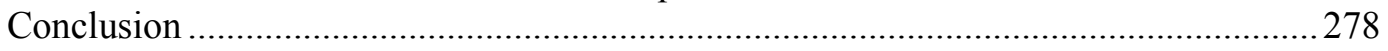

Chapter 5 - Final Comparisons: Christian and Hindu Worldviews and Ideas of Warfare

1. What is? (Ontology - what is the model of reality) ................................................283

Understanding the Human Condition ............................................................................28

2. Where does it all come from? (Explanation - a model of the past) .............................291

Creation myths ........................................................................................................ 291

Conception of God..................................................................................................296

3. Where are we going? (Prediction - a model for the future)............................................ 302

4. What is good and what is evil? (Axiology - theory of values) .....................................307

5. Theory of action, or praxeology (How should we act?) …………………………........312

6. What is true and what is false? (Epistemology - theory of knowledge)......................318

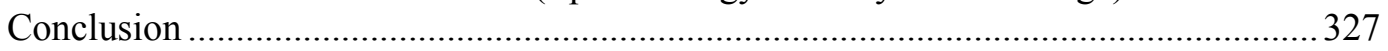

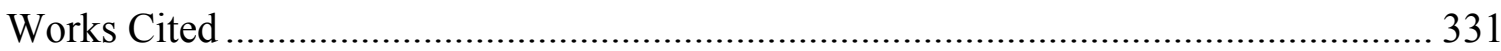

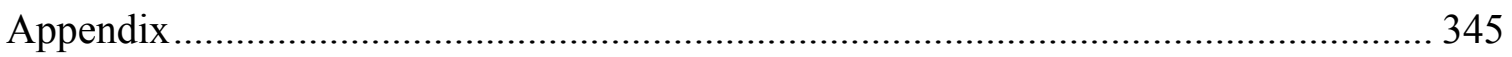




\section{Introduction}

As a man thinketh in his heart, so is he.

(Proverbs 23:7)

\section{Religion and War}

Congregations of the Christian faithful, even in our time, make petitions of prayer to God in times of war, calling upon Him "to bless or supplement their own violence with divine power" (Nelson-Pallmeyer 5), although the message of Jesus in the Gospels appears to be one of peace. Of course, the power of God is equally invoked by nonChristians, but it is the Christian doctrine of the just war that has been incorporated into international law and it is the Christian-influenced Western philosophical discourse that continues to shape how modern rules of warfare are crafted - rules which the whole world is expected to adhere to. However, we fail to see how Western concepts of war, which are so shrouded in secularism ${ }^{1}$ and institutionalised in legally enshrined mechanisms of UN declarations, treaties and frameworks are actually the result of a particular Christian worldview.

The purpose of this dissertation will be to examine some of the metaphysical assumptions that inform how people think about warfare. Throughout recorded history, people have always looked for ways in which they could maintain a clean conscience while killing or wounding other people. Rules were developed which outlined who could fight, and when and how one was to fight and against whom one was to fight. In the West, this developed into what is known as the just war doctrine, and St. Augustine is

\footnotetext{
${ }^{1}$ For further information on how religious fervour in the West has "migrated" towards the state and in support of the state, see William T. Cavanaugh, Migrations of the Holy: God, State, and the Political Meaning of the Church, Grand Rapids, MI: Wm. B. Eerdmans Publishing Company, 2011. Cavanaugh argues that people in the West have substituted a willingness to die for the church to a willingness to die for the state. The language of nationalism becomes a new liturgy which convinces Christians to sacrifice their lives to serve and defend their country and its values.
} 
often acknowledged (especially by Christians) as the person who introduced these ideas to Western philosophy. Nine hundred years later, Thomas Aquinas, another Catholic priest, used Augustine's arguments to explicitly enumerate the conditions by which a war could be considered just. However, as Frederick Christian Bauerschmidt states, Aquinas' political theology is based not on his appeals to natural law, but is in fact rooted in "his identification of truth with the God of Israel, incarnate in Jesus Christ" (48). There is an explicit connection between the religious convictions of Augustine and Aquinas and their arguments about just war. In other words, the worldview (Weltanschaunng) of these Christian priests and saints influenced their ideas of war, much as they influenced all notions of Christian justice and morality, and this worldview is constructed using Christian metaphysical assumptions. These assumptions contain certain fundamental notions by which people understand the world and their place in it. However, Bauerschmidt does not elaborate further on what assumptions Aquinas had, nor does he explain how these assumptions influence his ideas of war. Therefore, the first part of this dissertation will unveil how aspects of Christian theology and metaphysics influence Christian ideas of warfare. As Andrew Fiala states, "When we examine the details of the Augustinian basis of the just war idea we should have reason to be skeptical of the tradition that develops in Augustine's wake" (34). This is the reason for this first line of inquiry.

If Western ideas of warfare are rooted in "the God of Israel, incarnate in Jesus Christ", this raises an important question. What if this theology were rejected? What if many of the metaphysical assumptions that Augustine and Aquinas held are no longer held by Christians? If the answer to either of these questions is yes, then would the 
whole idea of a just war crumble? Discussing the validity of the just war doctrine, though, is not the aim of this dissertation; unravelling the theology behind the doctrine is. Consequently, as a way of testing how Western notions of just war would fare if the Christian worldview were taken out of the picture, I have decided to examine Hindu metaphysical assumptions to determine how they influence Hindu ideas of warfare. Hinduism has a completely different theology that encapsulates metaphysical assumptions which are fundamentally different from those of Augustinian Christianity, and many people see Hinduism as a religion of peace, the religion of Gandhi. What kind of contribution would Hindu metaphysical assumptions make to the construction of a doctrine of just war? This question will be examined in the second part of this study.

\section{Problems of Warfare/Problems of Christianity}

What the dawn of the twenty-first century has shown us is that the nature of warfare has changed. Modern terrorism brings with it a new set of actors: disparate groups of individuals from a variety of countries (both East and West) with varying ideologies and a seemingly endless list of targets that include financial institutions, international governance institutions, as well as purely civilian targets. However, the response of the international community, particularly the US in the wake of $9 / 11$, was to resort to traditional warfare, and invoke traditional just war criteria. ${ }^{2}$ One decade later, traditional warfare does not seem to have achieved the desired result. Iraq and Afghanistan have shown signs only of increasing terrorist activities. Attacks in the West, and even in East continue. Some estimates claim that the increase in terrorist activity has

\footnotetext{
${ }^{2}$ Interestingly, both Pope Benedict and Rowan, Archbishop of Canterbury, condemned the Iraq war saying that it did not meet the criteria for a just war.
} 
increased three-fold following 9/11 (United Press International). It seems clear that conventional warfare has no real effect in combating the violence of terrorism, and in fact, may even contribute to the escalation of violence. Political stability in Iraq and Afghanistan has still not been achieved, and terrorist elements continue to proliferate causing regional instability and uncertainty. Yet, war, as a legitimate exercise of statecraft remains viable.

In its two thousand year history, Christianity has encouraged and condoned many shameful practices: crusades, inquisitions, slavery, colonialism, suppression of the rights of women (abortion, voting, citizenship), suppressing sexual minorities, cultural genocide of non-Christian groups, the suppression of scientific discovery and teaching of scientific principles, environmental overexploitation, and capital punishment were (or still are) justified by references to the Christian Bible. ${ }^{3}$ Of course, this does not deny that such evils may also be justified and encouraged by other religions or by non-religious ideologies. However, Christianity has undoubtedly dominated Western thought and influenced world history more than other religions. Many of these "evils" were eventually extinguished, and even today, changing interpretations of scripture and refinements in Christian philosophy are attempting to change current attitudes. Christianity seems to offer a solution for the very problems it caused. Furthermore, Christianity may also be responsible for much good: freedom and rights of the individual, justice, due process of law, emphasis on education, and developments in language, literature and the arts also arose as a result of Christianity. However, the idea

\footnotetext{
${ }^{3}$ For more detail on the links between Christianity and this list of accusations, see John Shelby Spong, The Sins of Scripture: Exposing the Bible's Tests of Hate to Reveal the God of Love, New York, NY: HarperCollins Publishers, 2005. See also The Blackwell Companion to the Bible and Culture, John F.A. Sawyer (ed.), West Sussex, UK: Blackwell Publishing Ltd., 2012.
} 
of war as a legitimate exercise of state power is one that continues to persevere in the philosophical discourse of many Christian denominations today.

This perseverance can also be seen in international law. Shortly after 9/11, just war criteria that are almost identical to those proposed by two Christian saints, Augustine in the fifth century and Aquinas in the thirteenth century, continued to form the structural framework of the recommendations of the International Commission on Intervention and State Sovereignty in their set of principles regarding state sovereignty entitled Responsibility to Protect (R2P). In January 2009, these recommendations were endorsed and reaffirmed when UN Secretary-General Ban Ki-moon released a report called Implementing the Responsibility to Protect. This dissertation will provide some answers for why this kind of thinking persists by suggesting that it is the lingering metaphysical assumptions of Augustinian Christianity which continue to keep the just war tradition alive.

\section{The Relevance of Hinduism}

My reasons for looking at Hinduism are many. First, is modern India's rise in importance in the world as a regional power and potential economic superpower. One in six people on the planet is Indian, and India developed a philosophy independent from the Greek-influenced thought of the West. Hinduism is also the precursor to the other great religion of Buddhism, which influences China, Thailand, Japan, Myanmar and Sri Lanka, as well as being influential on Sikhism and Jainism in India. Second, from a just war academic perspective, unlike the New Testament in which the main event is the life, death and resurrection of Jesus, the main event in the Bhagavad Gītā, is a great war 
between two families. Hindu scriptures form some of the earliest, well-developed formulations of what one should do in the face of battle - what some would call a theory of just war. ${ }^{4}$ However, despite all these factors, there is a real lack of material that focuses exclusively on the just war doctrine and Indian philosophy. The various communities that made up the subcontinent are a mosaic of different cultures, languages, religions, races and foreign influences that have somehow held together (notwithstanding the relatively recent partition and creation of Pakistan and Bangladesh), although not necessarily always peacefully. India has, however, survived, often amalgamating those that conquer her into an already diverse mixture. Many believe that part of this cohesion is due to the Hindu ethos that pervades the subcontinent. The modern Indian state too is trying to maintain a commitment to secularism in government, a universalism in the human approach to the outside world, and ideas of peaceful co-existence when dealing with foreign powers of different faiths and beliefs. Perhaps Indian philosophy writ large could make a valuable contribution to the world. Third, and perhaps most importantly, I am looking at Hinduism because the metaphysical assumptions it makes differ so radically from those of Christianity. Fundamentally, Christian metaphysics assumes that the soul (the non-material essence of individual existence that survives the body) goes through one cycle of earthly life, followed by reward or punishment in the afterlife.

\footnotetext{
${ }^{4}$ As Kaushik Roy notes, one must be aware of certain limitations in drawing conclusions from a text-based study. The importance of these texts in pre-modern India was perhaps lower than the importance of Hindu iconography in a population with a very low rate of literacy. It is difficult to prove/show a direct connection between concepts expressed in various texts and their execution/implementation in reality by strategic/military managers (Roy, Ethics of Warfare 261). While being aware of these caveats, I still think that making these connections between Hindu texts, Hindu assumptions about reality and the influence on thinking about warfare is a useful philosophical exercise, because, as Roy says, "warfare and the politics associated with it cannot be explained merely by referring to realist/neo-realist theories. [...] Warfare (its origins, conduct and consequences) is certainly shaped by cultural traits, and culture is also partially shaped by organized violence and the material setting. [...] At least in the Indian case, military organizations have been subordinated to the wider cultural ethos, which to an extent is shaped by Hinduism" (Ethics of Warfare 263-64).
} 
Hinduism, by contrast (especially from an Advaita Vedānta perspective) through its doctrine of karma and reincarnation assumes that the soul goes through many different cycles of life before achieving liberation from the cycle of birth and death and becoming one with the spirit of the universe (Brahman).

\section{Outline of the mode of inquiry}

Firstly, the connection between a Christian worldview and just war theory will be established. Secondly, I will examine how Hindu political thought has described the role of warfare and I will expand on the elements of a Hindu worldview in order to determine how Hinduism responds to the idea of war. Finally, I will try and link worldviews to ideas of war in order to make inferences as to whether an Augustinian Christian worldview and its resulting political theology is more inclined to provide justifications for war than would a Hindu Vedic worldview. ${ }^{5}$ In order to make these inferences, I will also make reference to how violence in general (treatment of women, animals, ideas of sacrifice) is viewed by Hindu and Christian traditions. Researchers have found a moderate positive correlation between interpersonal violence and warfare: "Internal conflict is a good predictor of the level of external conflict, and external conflict is an excellent predictor of internal conflict" (Ross 553, also see Ember and Ember).

\footnotetext{
${ }^{5}$ It is important to note that whenever I refer to a Christian worldview, I am actually referring to those elements of Christian metaphysical assumptions that can be traced back to Augustine. This is therefore, a fifth century Roman Catholic point of view, although this still continues to influence Christian thought on war today. Similarly, when I refer to Hinduism, with its even more complicated division of sects, I am referring to a Vedic Hinduism through the Advaita Vedānta tradition which relies on Sanskrit texts, of which the most influential is the Bhagavad Gita. I realise that there are some texts found in the Tamil literature of the South, as well as the purạna texts but these will be ignored for the purposes of this analysis.
} 


\section{Methodology}

Much as languages have grammars, religions too have grammars. The various parts of speech which make up language correspond to the various doctrines of religion which influence adherents to adopt a particular worldview. The methodology used by comparative religion scholars to compare different faiths will be employed to examine the beliefs of the faith with respect to various elements. These elements include the following "big", "eternal" or "age-old" philosophical questions which could be used as a framework for comparing any systems of symbols or assumption, theistic or otherwise:

1. What is? (Ontology - what is the model of reality)

2. Where does it all come from? (Explanation - a model of the past)

3. Where are we going? (Prediction - a model for the future)

4. What is good and what is evil? (Axiology - theory of values)

5. How should we act? (Praxeology - theory of actions)

6. What is true and what is false? (Epistemology - theory of knowledge). ${ }^{6}$

These elements in Hinduism and Christianity will be examined and compared, placing emphasis on how these elements specifically impact ideas of war. Since sacred texts are important sources of knowledge in religion, mining sacred texts for insight into the teachings of Christianity and Hinduism concerning war will also constitute an important part of this study. In interpreting the grammar of religion through sacred texts, renowned comparative religion scholar Huston Smith says that one must examine the following, in ascending order of importance: the literal; the ethical; the allegorical; and, the anagogic (Rosemont and Smith 15). This will be the method of interpretation used when analysing

\footnotetext{
${ }^{6}$ I have used the list developed by Belgian philosopher Leo Apostel "What is a worldview?" Apostel also adds: "There is in fact a seventh question, which is a meta-question, asking 'Where do we start in order to answer those questions?' It invites us to seek for partial answers found in the history of ideas and civilizations, preferably being aware of their tradition of thought, and their more or less hidden assumptions. This step is important, for example, to build a world philosophy. More generally, philosophical anthropology and history of philosophy operate at this meta-level, allowing a broader analysis of the evolution of different worldviews". By examining religious and political texts, as well as historical backgrounds, this study has attempted to bear Apostel's meta-question in mind at all times.
} 
passages in scripture that relate to warfare. In addition to sacred texts, I will look at secondary sources which discuss the life and times of their authors (Augustine, Kautilya, etc.) and the sources of Christian and Hindu political theology. I will also explore some of the literature in the field of comparative religion and comparative theology. Finally, in order to assess the impact of a particular religious viewpoint, I will examine some of the work done by (scholars in the areas of literary criticism and depth psychology, and finally the works of modern Christian and Hindu authors who describe their worldview will be used.

This research utilises the theoretical model of constructivism ${ }^{7}$ which holds that significant aspects of international relations are historically and socially constructed. In doing so, this model examines the social construction of ideas, which occurs through social interaction and social practice. If religion is defined as a "cultural system" in which narratives, symbols, traditions and sacred histories are used to give meaning to life or to explain the origin of life or the Universe (see Geertz), then exploring these narratives, symbols, traditions and sacred histories will provide a great deal of information about a culture, how they derive morality, ethics, religious laws, preferred lifestyle and attitude towards war because religion is the basis for many social constructions.

\footnotetext{
${ }^{7}$ The term constructivism here refers to the framework developed by Nicholas Onuf in World of Our Making, Columbia: University of South Carolina Press, 1989, as it is the framework that International Political Theology proponent Vendulka Kubálková adopts. She describes it as "integrating IR and religion and their study with the way the knowledge of them is constructed. It will be at the same time - if you like - a political theology of the study of religion in International Relations" (Kubálková footnote 3).
} 


\section{The Connection between Religion and International Relations}

Scott Thomas points out that the global resurgence in religion is transforming our understanding of international relations (1). He cites the Iranian Revolution, the rise of the Polish Solidarity movement and the tragedy of September 11, 2001 as examples of momentous, transforming events. He states that none of these events were predicted because experts and observers did not know where to look because the rise of religious fundamentalism was ignored as an influence on social and political change. More recently, it is the events of $9 / 11$ that traditional scholars have had the greatest difficulty explaining, and Thomas thinks this is owing to their inability to look beyond a secular understanding of international relations. As Thomas says, "Something else is going on in the world. A more global perspective on religious violence is needed. In 2001 over half of the 34 serious conflicts around the world had a religious dimension to them" (9). Thomas also sees this type of conflict and terrorism by non-state actors as being on the rise, and he says that these new actors have no limits when it comes to violence. ${ }^{8}$

However, I do not think that the importance of religion should only be regarded with respect to Islamist terrorists but also in other responses to international conflicts and crises since the start of Christendom, indeed, perhaps since the start of organised religion. Robert Keohane admits, "the attacks of September 11 reveal that all mainstream theories of world politics are relentlessly secular with respect to motivation. They ignore the impact of religion, despite the fact that world-shaking political movements have so often been fuelled by religious fervor" (qtd. in Thomas 11). I believe that US foreign policy

\footnotetext{
${ }^{8}$ It is not entirely true that they have no limits though. For example, in the recent Woolwich killing of British soldier Lee Rigby, the two men who killed him did not attack any other people at the scene and even apologised to the woman who was present because she had to witness the killing (see Dodd, Malik and Quinn). There are some limits that are set, however, we might not always be correct in identifying what those limits are.
} 
following 9/11 has just as much to do with American religiosity as the events of 9/11 had to do with a fundamentalist Islamic religiosity. The motivation for the US and its coalition of the willing to get involved in Afghanistan and then Iraq is the result of (at least in part) a Christian theory of just war that is rooted in a Christian religious fervour. In addition, these ideas, which are touted as universal, are instead very historically and culturally specific to Roman Christianity - a Christianity that has undergone schisms, reformations, counter-reformations, two Vatican Councils - and a Christianity which today is undergoing dramatic reformulations in order to remain relevant in the twentyfirst century. Yet, developments in international law surrounding warfare seem to continue clinging to the ideas of Augustine written over fifteen centuries ago. The purpose of this work is to encourage not only Christians but also anyone schooled in the Western tradition to consider from where and how their ideas surrounding warfare emerge, and perhaps to further dialogue so that a better understanding of other worldviews can be obtained.

\section{Embracing International Political Theology (IPT)}

In the mid-nineties, Vendulka Kubálková proposed a new field of IR, International Political Theology. ${ }^{9}$ Kubálková argues that the positivist slant especially in American IR theory continues to view religion as a private affair of individuals, a

\footnotetext{
${ }^{9}$ She describes "theology" in the following way: “"Theology' was once synonymous with philosophy and science. Following the understanding of sociologists of religion, I take 'theos' not in its common secular meaning as 'erroneous beliefs in supernatural extraterrestrial existence', but I take 'theology' and 'theos' to refer to the systematic study of discourses and relations amongst them concerning world affairs that search for - or claim to have found - a response, transcendental or secular, to the human need for meaning. My purpose is to find a way of bringing the study of religion and IR together - possibly for the first time - in a manner which would minimize their distortion and facilitate their understanding" (Kubálková 6-7, footnote $5)$.
} 
domestic affair of states or as liminal. The meaning of religion for analytic purposes is lost as religions are reduced to institutions which are "treated as one amongst many epistemic communities, or as nongovernmental or transnational organizations" (qtd. in Petito and Hatzopoulos 81, 86-7). However, she points out, "We tend to forget just how brief the modern period in the history of ideas has been. Until only two hundred years ago or so, religions provided the dominant mode of thought, and thus many ideas even today have their root in religion" (qtd. in Petito and Hatzopoulos 84). ${ }^{10}$ Her key thesis is that "religions are a possible manifestation of assertive rules that we have tended to dismiss as nonmodern, primitive and nonrational, if not irrational" and that Western society depends on linguistic and nonlinguistic forms derived from these prescientific assertive rules (qtd. in Petito and Hatzopoulos 92). “One's identity, one's understanding of the world, one's main values, are typically received in assertive rules articulated by human agents, albeit based on revelation, and $[\ldots]$ when internalized they constitute the core of consciousness and culture" (qtd. in Petito and Hatzopoulos 95). I believe that my research furthers the understanding of the connection between religious ideas and statecraft, especially the decision of states to go to war.

Kubálková notes that the origins of human religious experience are beyond the realm of human rational choice, around which most social science discourse seems to revolve (Kubálková 15). She advocates an interdisciplinary approach, incorporating

\footnotetext{
${ }^{10}$ This is similar to the argument of Kaushik Roy who, citing Ken Booth, argues that understanding the "strategic culture" of another country on its own terms is important in understanding the motivations, selfimage and behavioural patterns of a particular country. Roy notes that military historians highlight the interrelationship between culture and warfare (Roy, Ethics of Warfare 2-3). If culture is, as one of the definitions in the Oxford English Dictionary puts it, "the ideas, customs, and social behaviour of a particular people or society," understanding a culture's metaphysical assumptions may provide insight into what motivates these cultures to go to war. "Warfare is the product of both social and cultural forces" (Roy, Ethics of Warfare 4) and religions are a sort of socio-cultural system.
} 
ideas from philosophers, historians of religions, sociologists of religion, theologians, international lawyers and jurists (Kubálková 8), and I have adopted this approach throughout this research. Kubálková laments the fact that the number of scholarly contributions where religion intersects with IR has been small, especially so in North America (Kubálková 8). I hope that the research presented in this work will contribute to research in IPT. 


\title{
Chapter 1 - A Genealogy of the Just War:
}

\section{A Survey of Christian Political Thought on the Justification of Warfare ${ }^{11}$}

\author{
Earth is sick, \\ And Heaven is weary, with the \\ hollow words, \\ Which States and Kingdoms utter \\ when they talk, \\ Of truth and justice. (Wordsworth)
}

\section{Introduction}

This chapter will outline the development of the just war doctrine, with special emphasis on the developments in Christian thought which ultimately influenced modern international legal documents. ${ }^{12}$ Numerous legal documents, such as the Geneva Conventions (1864-1948) contain within them references to just war. More recent attempts to codify the just war include the Report of the International Commission on Intervention and State Sovereignty entitled Responsibility to Protect. In examining the development of Christian thought with respect to war, I will illustrate the link between developments within Christian philosophy, the precepts of the Bible, and ultimately, the eventual universalisation of certain elements of Christian morality through the intermediary of natural law.

\footnotetext{
${ }^{11}$ This chapter is a revised version of my earlier publication (see Keith Gomes, "An Intellectual Genealogy of the Just War: A Survey of Christian Political Thought on the Justification of Warfare").

${ }^{12}$ From the time of St. Thomas Aquinas'Summa Theologice (1265-1274) to the Catechism of the Catholic Church (1993), the Catholic Church continues to uphold the tradition of the just war. In the most succinct terms, this chapter will look at how the framework of a very Christian document (Summa Theologice) came to be incorporated into a very secular, international document (Responsibility to Protect) that aspires to describe and influence current international normative and legal frameworks. I will in essence try and follow the paper trail and provide a literature review of the writings that inspired the thinking behind these documents. (See Appendix for a synoptic table comparing the relevant portions of the above documents).
} 
The need for just war criteria represents the efforts of Western cultures to regulate and restrict violence by establishing rules that specify the situations in which $\operatorname{war}^{13}$ can be legitimately used as a tool in international statecraft, as well as setting out rules that govern ethical conduct during combat. However, today these regulations and restrictions are not confined to only Western cultures but, because of developments in international law and the establishment of international organisations such as the UN, this once Western narrative is seen to have universal relevancy, and to a large extent, universal appeal and applicability (J.T. Johnson 4). Under the idea of just war, a further dichotomy exists: just war rules are generally characterised as jus in bello and jus ad bellum - the latter refers to the rules governing the decision to go to war, while the former refers to rules of engagement once the war is already underway. For the purposes of this work, I will focus solely on ad bellum requirements. ${ }^{14}$ However, both sets of rules arise from the same intellectual narrative which recognises recourse to violence not as the preferential modus operandi for dealing with disputes, but the exception. Both sets of rules trace their genealogy to developments in Christian thought, and understanding this genealogy is important, not only for academics, but for military strategists and foreign policy planners alike, since it highlights that these rules are never static because the rationale for them is situated in various historical contexts, and interpretations vary depending on the prevailing socio-political atmosphere. This, therefore, always leaves open the possibility

\footnotetext{
${ }^{13}$ One broad, but acceptable definition of war which might be used for the purpose of this work is the one offered by Andrew Fiala in The Just War Myth: "Wars are human activities in which groups of people are killed by other groups of people; and this killing has some political meaning, that is, it is about a struggle for power, legitimacy, and/or ideology" (Fiala 4).

${ }^{14}$ Some have extended this dichotomy perhaps to make the just war more just by adding jus post bellum, jus ad pacem and jus as interventionem (Fiala 10) as other requirements. Fiala notes that the Latin terms jus in bello and jus ad bellum serves as a reminder that the contemporary just war doctrine has its roots in the Latin of the medieval Catholic tradition and through the use of Latin terminology, "they are consecrated by a sort of reverential nostalgia for a time of chivalry" (Fiala 40).
} 
that at the very least, the interpretations of these rules can be modified, or at the most, that the rules themselves ought to be more closely scrutinised, given that Christianity itself is constantly evolving and reinventing itself to retain contemporary social, political and ethical applicability.

Of course, the just war doctrine is not the only available Christian approach to war. In some factions of the early Church, as well as amongst later groups (such as the Quakers, Mennonites, Hutterites, Amish and Brethren), pacifism and an abhorrence of all forms of war were, and continue to be advocated. However, since my goal is to show the continuity of thought from the ideas of the early Church to the ideals of modern institutions, such as the United Nations, I will not be focusing on these dissenting ideas within the Christian tradition, as from a political perspective, and with reference to modern international law, the just war appears to dominate. As Inis L. Claude Jr. argues, "the League of Nations and the United Nations are among the organizations that have served as instruments for the implementation of the doctrine of just war" (83). Also, while I acknowledge just war concepts do pre-date Christianity, and that non-Christian perspectives may also include just war formulations, my assertion is simply that modern, international, secular discourse on the justifications of war finds its genesis in the Christian tradition of just war.

\section{Starting Point: Christianity's Jewish Heritage}

For Christians, the Bible is the inspired Word of God and, together with Church tradition, is the source and basis of all Christian thought. Christians believe that the Bible holds the key to answering questions of justice, ethics and morality. However, even 
those with more than merely a cursory knowledge of the Bible will note that trying to find an unambiguous message in the Bible when it comes to politics is an impossible task. As William Blake penned: "Both read the Bible day and night / But thou readst black where I read white" (qtd. in Rowland 21). Thus, all kinds of social injustices, such as slavery, racism, apartheid, homophobia, suppression of women's rights and the right to exploit the environment have been (and in some cases, continue to be) perpetrated by Christians who claim to be using the Bible as their guide. In addition to the problem of understanding the Bible, Christianity, unlike the other Abrahamic religions, has the additional complication of trying to reconcile one set of beliefs from the Jewish teachings of the Hebrew Bible (which form the Christian Old Testament) with the teachings of Jesus and his followers as described in the New Testament. However, these two sets of belief are not always compatible. The theology of Biblical Judaism is vastly different from that of Christianity. Many concepts that are an integral part of Christian belief, such as the belief in Hell, the idea of Satan, the Incarnation, the Trinity, etc. are completely alien to Jewish faith. ${ }^{15}$ Even the personality of God himself appears to change. The Jewish jealous God inflicts his wrath on those who disobey him or those who seem to get in the way of His plans for his chosen people, whereas the Christian God seems to offer forgiveness and mercy. The God of the Old Testament demands that his people adhere to a myriad of strict rules and regulations in their daily conduct, whereas Jesus in the New Testament seems to be more concerned with his followers' attitude and about conversions of the heart rather than strict adherence to outward acts of piety. The decision of the Church to include the Jewish scripture in its canon meant that notwithstanding the New

\footnotetext{
${ }^{15}$ Although ideas like Hell and Satan do appear in Second Temple Judaism, these ideas would have not been mainstream views at the time of Jesus.
} 
Testament's passive disposition, war was also justified in scripture through the Old Testament. However, in the Middle Ages, even the New Testament was seen as providing justification for war (Hazlett 116-18).

\section{Monotheism and the Violence-of-God}

Judaism did not always embrace monotheism, but these ideas developed gradually over generations. Ultimately, a monotheistic outlook was imposed by priestly writers, although these views may not have fully resonated with the views of the ordinary people, and these ideas were written back into a polytheistic text (Nelson-Pallmeyer 36-37). However, Jack Nelson-Pallmeyer notes that violence done in the name of God increased dramatically when these monotheistic ideas were imposed. Perhaps it is the idea of monotheism itself, that Christianity and Islam inherit from Judaism that results in war? The Hebrew Bible describes God as a jealous God, who opposed the worship of other gods and required his followers to destroy the religious symbols of other religions (see for example Deuteronomy 7:5-6). These priestly interpretations, however, may have done more to maintain the position of power of the priests than conveying any true divine message (Nelson-Pallmeyer 31). Along with the notion of a jealous God was the notion that Israel had been specially chosen by God. As Bishop John Shelby Spong argues, what this creates is a mentality that everyone else is God's rejected people: "Since God has particularly not chosen other people, rejection, hatred and prejudice are justified in the chosen ones, as they model divine behavior as they understand it. In this way, the world was divided into the chosen Jews and the unchosen Gentiles" (see Spong, Living in Sin, Chapter 2). Once transposed into Christianity, this kind of mentality facilitates 
justifying war when it is against non-Christians, or against Christians whom you view as heretics.

It is this violence-of-God tradition that formed the foundation for the Gospel writers, and even for the stories of the Qur'an. Today, Judaism, Christianity and Islam each purport to be upholders of the true religion given to Abraham. For Christians, Jesus is the fulfilment of Jewish scripture. For Muslims, Mohammed was God's final prophet and the Qur'an was revealed to correct errors in the Jewish and Christian scriptures. The monotheistic faiths seem to exhibit hostility towards the other because they reject and hate everything outside of their own religious tradition. Jewish writer Regina Schwartz explains that this hostility is rooted in the assumption that there is "a cosmic shortage of prosperity. Scarcity is encoded in the Bible as a principle of Oneness (one land, one people, one nation), and in monotheistic thinking (one Deity), it becomes a demand of exclusive allegiance that threatens with the violence of exclusion" (3). Monotheism's legacy was that it established the primacy of a single God through victory in battle. These victories were a result of the direct intervention of God and the unleashing of awesome divine violence. This results in firmly establishing a connection between superior violence and divine help and power so that the very notion of salvation in the Hebrew Scriptures was the defeat of enemies (Nelson-Pallmeyer 38, cf. Psalms 18:4528). This is a legacy of all three Abrahamic faiths: their texts contain stories "that God's overwhelming character is that of a violent, punishing, pathological Deity who uses unfathomable violence to both reward and punish, either within history or at history's end" (Nelson-Pallmeyer 29). This kind of thinking justifies violence done in God's name and legitimates violence as a means to achieve justice (Nelson-Pallmeyer 43). 
Another related theme to being God's chosen is that of liberation. Stories of the oppressed nation of Israel triumphing over its enemies seem to promise divine aid to those who are oppressed. It might encourage rebellion because the oppressed believe that God will fight for them. Non-violent options to overcome injustice may be ignored because power in the sacred texts of the Abrahamic faiths is associated with coercive violence (Nelson-Pallmeyer 43-44). Along with stories of liberation, the Hebrew Bible also describes stories of exile, when the Israelites are taken away from their land as a consequence of sin. Biblical writers explained exile as the deserved punishment for their disobedience to God. Victory was promised to the people if they obeyed God, and the Bible seems to have numerous accounts of the Israelites triumphing over their oppressors, followed by accounts of Israelite despair when they are defeated by their enemies, ostensibly because of their disobedience to God. When Israel's faith was renewed, a new liberating prophet emerges and God's power would again work in favour of the Israelites. Eventually, however, the liberation promised by the prophets never materialised. This led to another theological development - apocalypticism - which can best be seen by looking at the prophet Daniel. Traditional explanations of liberation/punishment did not seem plausible when around 167-164 BCE the Seleucid ruler Antiochus IV prevented the Jews from practising their religion under penalty of death. Faithful and pious Jews were slaughtered. Daniel's explanation was that although God did not want the Jews to be oppressed, he was preoccupied with battling the forces of evil in heaven, and he would eventually bring victory to the Jews once he triumphed over evil in heaven (Daniel 7:23, 25-26). The other innovation of Daniel was in announcing that God would come violently to destroy human evil, but this would only happen at the end of time (Daniel 
$8: 17 ; 10: 14 ; 11: 35 ; 12: 13)$. This led to a third innovation - the idea of resurrection. Daniel preaches: "Many of those who sleep in the dust of the earth shall awake, some to everlasting life, and some to shame and everlasting contempt" (Daniel 12:2). These kinds of ideas moved from Judaism to Christianity and Islam.

These stories make blunt distinctions between good and evil, insiders and outsiders, those deserving of rewards and punishments. The spiral of violence imbedded in these "sacred" texts spills over into human violence in real history and within Scripture itself. [...] God becomes an instrument of human revenge. Compassion and salvation are militarized, that is, understood as the crushing defeat of enemies within or at the end of history. (Nelson-Pallmeyer 54)

\section{War in the Old Testament}

War in the Old Testament was either intended as a sacrifice of non-Hebrews to ensure Yahweh's aid in battle, or as a purification of the Hebrew community by eradicating injustice and evil outside the community. In their wars of conquest, the "ban" (Hebrew: harem) demanded that all people were to be killed (see Deuteronomy 20:1018). Nonetheless, war was not perceived as the ideal solution, and steps were taken to avoid it. Diplomatic efforts were undertaken by messengers and ambassadors first (see Judges 11:12-28, 1 Samuel 11.11-10, 1 Kings 20:2-11). The enemy was also given the chance to surrender before an attack was made, but once the attack was made, it was total:

When you draw near to a town to fight against it, offer it terms of peace. If it accepts your terms of peace and surrenders to you, then all the people in it shall serve you at forced labour. If it does not submit to you peacefully, but makes war against you, then you shall besiege it; and when the Lord your God gives it into your hand, you shall put all its males to the sword. You may, however, take as your booty the women, the children, livestock, and everything else in the town, all its spoil. You may enjoy the spoil of your enemies, which the Lord your God has given you. Thus you shall treat all the towns that are very far from you, which are not towns of 
the nations here. But as for the towns of these peoples that the Lord your God is giving you as an inheritance, you must not let anything that breathes remain alive. You shall annihilate them-the Hittites and the Amorites, the Canaanites and the Perizzites, the Hivites and the Jebusites - just as the Lord your God has commanded, so that they may not teach you to do all the abhorrent things that they do for their gods, and you thus sin against the Lord your God. (New Revised Standard Version, Deuteronomy 20:10-18)

The Israelites always turned to God before their battles. They did this through the use of priests, who stood before the Ark and consulted with oracles (the Urim and Thummim) (See Judges 20:27-8, 1 Samuel 14:18, 28:6, 30:7) or through dreams, prophets or spirits evoked by a witch (Judges 7:17, 1 Samuel 28:6, 1 Kings 22:15).

However, there may be a development in the texts of the Old Testament - a gradual shift "from the primitive barbarism of captivity in Egypt to the more complex ethical civilization in the Maccabean period (second and first centuries BC)" (Webster and Cole 55). This shift might be related to the occupation of land by the Israelites. In the earlier part of the Old Testament, God's promises to the Israelites focussed on making available the Promised Land. However, as we approach the texts of the New Testament, there is no promise of land, and therefore, these seemingly more progressive texts, which have limitations on the "ban", seem to emphasise wars of defence rather than wars of conquest. These texts however (e.g. 1-3 Maccabees) are not part of the Jewish Bible as they were written in Greek, but they do form part of the Catholic Old Testament.

In the Jewish Bible, God commands the waging of war through religious leaders. If they obey God's command, the Hebrew people would prevail against their enemies. The Israelites always went to battle accompanied by a priest whose duty it was to safeguard the spiritual wellbeing of the troops and to inspire and reassure them before 
battle (see Deuteronomy 20:2-4). The High Priest himself may have also gone into battle, accompanied by the Ark of the Covenant, and the war was further sanctified by fasting and making burnt offerings to God (Judges 6:20, 26; 20:26, 1 Samuel 7:9, 13:10).

Besides conquest and destruction of enemies, war was also used to discipline the people. For example, in the Golden Calf incident in Exodus 32:36-8, Moses is ordered to kill those who did not worship Yahweh.

\section{Explanations for the Old Testament Images of War}

One rationale for the destruction commanded by God in the Old Testament is the political situation of the Israelites at the time these texts were written. Israel was a nation struggling for survival, and a theocracy, where every action of the state has religious consequences, including victories or losses in battle. Occupying a specific land was seen as their divine destiny as a chosen people who were promised a land flowing with milk and honey for their homeland (Exodus 3:17) (Clough and Stiltner 24-25). As a chosen people, all who were not chosen had to be eliminated because it was not part of God's plan. Another way of understanding the especially harsh total destruction demanded in the Old Testament is that it really had nothing to do with brutality, but instead with ritual purity. Leviticus 19:19 states "You shall keep my statutes. You shall not let your animals breed with a different kind; you shall not sow your field with two kinds of seed; nor shall you put on a garment made of two different materials." Similarly, the "ban" prevented the mixing of Israelites with foreigners lest their customs and traditions became corrupted (Clough and Stiltner 26). Yet another explanation for Old Testament stipulations is that the Lord himself is viewed as fighting for Israel. In the Exodus story, it is not the 
Israelites but God who defeats Pharaoh's army. In the book of Joshua, the Lord is said to fight for the Israelites (Joshua 23:9-10). Yahweh's fighting on behalf of Israel is part of the fulfilment of the covenant between God and Abraham (Clough and Stiltner 27).

After the destruction of the Temple by the Romans in the first century CE, Jews were forced to live in the diaspora. Michael Walzer claims during this time that there is no Jewish theory of war and peace because Jews, being stateless and in exile only wrote for themselves with regard to their circumstances and not with reference to any actual existing international society ("War and Peace in the Jewish Tradition" 95). Jews were usually the victims of wars, not the agents, and without a state, they were also not theorists of war ("War and Peace in the Jewish Tradition" 96). The state of international affairs from a Jewish perspective seems rather Hobbesian - as a state of war - since perfect peace (shalom, which Walzer says is related to the word for completion, wholeness or perfection) is only really possible in the Messianic age. Therefore, war appears to be "an inevitable feature of the pre-Messianic age" and "[f]riction between human beings leading to military engagement is understood as an inevitable feature of earthly life" (Cohn-Sherbok 93). In fact, many Jews today no longer believe in the coming of the Messiah who will establish peace (Cohn-Sherbok 93).

The Jewish dichotomy of war as presented in the Mishnah - a compendium of Jewish law from the second century - is not one of 'just' and 'unjust' but 'divinely commanded wars' (milhemet mitzvah) and 'permitted wars' (milhemet reshut) which were optional or discretionary. The latter is defined as a war engaged in by the king to secure his border or to obtain glory and had to be first sanctioned by the Sanhedrin who would decide on the legality of such wars. However, the divinely commanded wars were 
generally agreed to be wars of self-defence (Cohn-Sherbok 88). There is no category of 'forbidden war'. There are some conditions that are disapproved of, but these only occur in the context of a permitted war (such as disapproval of wars of religious conversion or wars for civilisation). Permitted wars are those which include wars of self-defence (for the Talmud contains the maxim: If someone comes to kill you, kill him first (qtd. in Cohn-Sherbok 87, see also Walzer "War and Peace in the Jewish Tradition" 97-99)) or wars to safeguard the nation of Israel (also see Ravitzky 117). Walzer notes that "there is nothing in the Jewish tradition that requires, or even that provides a vocabulary for, a moral investigation of particular Jewish wars" "War and Peace in the Jewish Tradition" 104). There are certain jus in bello criteria - only besieging a city on 3 sides, not attacking civilians or their property, or not destroying trees for food (see Deut. 20:19-20)) - but nothing like the jus ad bellum criteria of Augustinian just war. Walzer states that God is not known to have made any specific or general prohibitions in warfare in Jewish scripture and these have been derived mainly through interpretation (s'vara - commonsense, reasonableness) ("War and Peace in the Jewish Tradition" 97). Dan Cohn-Sherbok seems to believe that this kind of interpretation continues to inform the politics of the modern Israeli state with respect to its Arab neighbours (97).

\section{The New Testament and War: From Pacifism to Just War}

Rather than any specific battle regulations, perhaps the three most important contributions Judaism made in the institutionalisation of war in Christianity were the idea of exclusivity of being God's chosen, the idea of one jealous God and the idea of liberation. This Jewish contribution is important to note because in the New Testament, 
the God of wrath and punishment in the Old Testament seems to be replaced by a God of love and forgiveness. However, Nelson-Pallmeyer still emphatically states: "God's liberating, punishing or apocalyptic violence is the named or unnamed assumption behind nearly every passage, story, and theological claim in the New Testament (original emphasis) (59).

The violence-of-God ideas that are uniquely Christian can be found in the recognition of the death of Jesus as a sacrificial atonement. One understanding of atonement is that we are saved from eternal damnation because God sent his only son to die in our place. The violence of punishment looms in the background, but we escape it through faith in Jesus. Jesus merely becomes the human scapegoat replacing the goat sacrifice of Yom Kippur as described in Leviticus 16. He becomes our proxy at his crucifixion saving us from damnation at the end of the world. Similarly, NelsonPallmeyer notes that the Eucharist, with its substitutions of bread and wine, echo the violence of the sacrificial Lamb of the Passover whose blood prevented the Israelites from being slaughtered (62). Jesus himself uses apocalyptic imagery in his teachings: "Just as the weeds are collected and burned up with fire, so will it be at the end of the age. The Son of Man will send his angels, and they will collect out of his kingdom all causes of sin and all evildoers, and they will throw them into the furnace of fire, where there will be weeping and gnashing of teeth" (Matthew 13:40-42).

After Jesus' death, the apostles' expectations were also firmly rooted in apocalypticism. This was for three reasons. First, it offered them a way to make sense of the death of their leader Jesus. They were able to personify the apocalypse by presenting Jesus as the person who would return soon to judge humankind, dispensing awesome 
violence on evildoers (cf. Revelation 14:9-10). Second, in the three or four decades after Jesus' death, before the Gospels were written, the Temple in Jerusalem as well as the city itself was destroyed by the Romans. The apocalyptic explanation for this was that it was divine punishment of the Jews for rejecting Jesus as the Messiah. And finally, an apocalyptic interpretation of Jesus served to fuel the flames of hatred of those Jews who had come to embrace Christianity. These Jewish Christians resented the fact that mainstream Jews repudiated their interpretation of Jesus as being the Messiah promised in Hebrew Scriptures. These mainstream Jews were blamed for the murder of Jesus, and the destruction of the temple and city was seen as divine punishment for their rejection of Jesus. Apocalyptic teaching condemned these Jews to eternal damnation (NelsonPallmeyer 68-69). With the idea of a violence-of-God tradition in mind, I will now examine how Christianity eventually came to develop just war thinking.

\section{Christian Politics Pre-Constantine}

Unlike the Israelite tribes of the Old Testament, the authors of the New Testament start as a small, fledgling Jewish sect who were persecuted by Jewish religious authorities who were themselves under Roman occupation. Early Christian communities were small and fragmented, socially marginalised and lacking in political power. Survival as a community of faith was their only concern (Clough and Stiltner 25). Before Constantine embraced Christianity, Christianity is non-conformist, that is, it is based on the principle that God must be obeyed first rather than any human authority as suggested by Peter and the apostles in Acts 5:29. This non-conformism led Christians to be accused of "turning the world upside down" (Acts 17:6) by non-Christians. There was an element of counter- 
culture - of replacing the dominion of Caesar with that of Christ. As a result, "the early Christians were known as members of a superstition, a deviation from the norms of accepted behaviour" (Rowland 23). The New Testament texts are written by people who had little or no political power whose vision of the world was contrary to the prevailing ideology. Their pattern of existence was characterised by the martyr spirit. From this came monastic asceticism and a withdrawing from society, first in the deserts of Egypt, in Europe with Benedict of Nursia, and later in the Middle Ages, with the monastic societies founded by Bernard of Clairvaux and Francis of Assisi. The formation of these separate communities (monastic or otherwise) was a way of seeking deliverance from the world whose values were "deemed antithetical to human flourishing" (Rowland 24) (see, for example Justin First Apology 14). Baptism into the Christian faith was seen as part of a process of "inculturation" into a new political culture and ethos (Rowland 24). They saw no compromise between God and Caesar and in a conflict of loyalty, the state and state authorities had to take second place to Jesus. However, there was also the idea that the kingdom of God on earth was imminent. Perhaps this eschatological hope simplified the choice - since they expected the dawning of the Messianic age, it was logical for these early believers to direct their efforts towards an allegiance with Christian conceptions of polity compared to Roman ones (Rowland 33). After all, Jesus himself said

You know that the rulers of the Gentiles lord it over them, and their great ones are tyrants over them. It will not be so among you; but whoever wishes to be great among you must be your servant, and whoever wishes to be first among you must be your slave; just as the Son of Man came not to be served but to serve, and to give his life a ransom for many. (Matthew 20:25-8)

This is a call to humility: a Christian king is the servant of the people. If a king wishes to be master, he cannot at the same time be a Christian (Rowland 26). Jesus himself is 
presented as the humble king in contrast to Herod. A king is one who washes his disciples' feet. In responding to Pilate by saying "My Kingdom is not of this world," Jesus is emphasising not location, but rather the operation of a different system of norms from those found in conventional kingdoms (Rowland 28).

Before Emperor Constantine's Edict of Milan in 213, only two Church Fathers regarded Christian participation in the Roman military as morally acceptable. St. Clement of Rome (the third successor of St. Peter) in his epistle to the Church of Corinth (96 CE) offered fervent prayers on behalf of the Roman Empire. He admired the discipline, readiness, and obedience of Roman soldiers. The other church father, St. Clement of Alexandria, also accepted the merits of Christians joining the Roman military, and praised the virtues of military commanders. Of course, the way of peace was always preferable (Webster and Cole 68-69).

Compared to the many references to wars in the Hebrew Bible, the New Testament is generally lacking in teachings on warfare, and what it does say appears contradictory. Many passages do not condemn the use of violence. For example, in John $2: 15$, Jesus uses a whip of cords to cleanse the temple, perhaps condoning violence to bring about social change. In Matthew 10:34, Jesus said that he came not to bring peace, but the sword. John the Baptist does not condemn soldiers for their profession but tells them to do violence to no-one, to refrain from false accusations and to be content with their wages (Luke 3:14). Jesus also says in Luke 22:36 that he who has no sword should sell his garment to buy one. However, certain other passages seem to prohibit Christian participation in war. Peter was commanded to sheathe his sword, for those who lived by the sword would die by the sword (Matthew 26:52). Even self-defence is prohibited as in 
the Sermon on the Mount, Jesus advised his followers not to resist evil but to turn the other cheek. He said that they should love their enemies and not judge one another. (Matthew 5:39, 41; 7:1; cf. Luke 6:27-9; Romans 14:13) He tells his followers to not take revenge but to leave vengeance for their injuries to God (Romans 12:19). In the next section I will examine some of these New Testament passages which make explicit reference to war and violence, and offer some brief interpretations of these passages which were used to justify the existence of warfare.

\section{The New Testament View on Warfare}

Jesus' teachings are incredibly rich in content, and although political messages may be difficult to read into them, stories in the Gospels do seem to paint him as somewhat of a revolutionary figure. He challenged interpretations of the Mosaic law, overturned the tables of the money exchangers in the Temple, violated norms of social intercourse by mixing with sinners and outcasts. He was tried by the Jewish authorities and found guilty of blasphemy, but eventually, he was crucified by the Roman authorities on charges of sedition and for claiming to be the king of the Jews, although Pilate's reaction seems to indicate that he did not believe that the accusations against Jesus were accurate. Ultimately, although his teachings tended to be focussed on the kingdom of heaven, there were attempts to apply these to how the righteous Christian was to live in society. These ideas do form modern world politics, although the connection to Jesus is often not palpable. As Tod Lindberg says:

Because the politics of the modern world is substantially Jesusian in character, the influence the political teachings of Jesus have had on us is easy to miss. His teachings come down to us not only directly, through his own words, but also through various religious and secular filters, from the 
doctrinal teaching of particular churches to the thought of philosophers indebted to him even if they rebelled against him. Our access to the Jesusian teaching does not begin with hearing a preacher spell out his ideas in a sermon delivered from a hillside or with the formal study of the Gospels, but with the daily activity of our own lives lived in large measure according to principles Jesus espoused. Some of us may be unaware of this influence, or only dimly aware, but it is there. (xi)

Part of this indirect influence can be seen from the Bible's many uses of military imagery, but these are used more as a call to arms for a spiritual war rather than an actual one. For example, St. Paul uses the terms "weapons of righteousness" (Corinthians 6:7; 10:5) or the "good fight of faith" (Timothy 6:12). 1 Thessalonians 5:8 and Ephesians 6:10-17 make use of defensive armour imagery "as metaphors for exhorting the Christians either to withstand the onslaughts of the devil or to continue in love and hope of salvation" (Webster and Cole 60). 2 Timothy 2:4 also uses a military analogy stating: "No one serving as a soldier gets entangled in civilian affairs, but rather tries to please his commanding officer". In this passage, it is an ordering of priorities that is important and not the actual profession of soldiering since the rest of the passage also makes analogies to an athlete, stressing the importance of obeying the rules of the sport, and to a farmer stressing the importance of hard work.

\section{The Soldiers Who Came to John the Baptist}

Perhaps the first New Testament incident which makes any specific pronouncements on soldiers is the reply of John the Baptist to soldiers who come to him for advice on what to do in order to receive John's baptism of repentance for the forgiveness of sins. John responds: "Do not extort money from anyone by threats or false accusation, and be satisfied with your wages" (Luke 3:14). This seems to indicate that 
these soldiers are not prohibited from remaining in their chosen profession, but John advises them not to abuse the power of their office to get more than what the law demanded. Therefore, merely being a soldier in the service of Rome was not an impediment to being baptised. St. Cyril of Alexandria, a fifth century Church father, observed about this passage that "as a skillful physician applies to each malady a suitable and fitting remedy, so also the Baptist gave to each mode of life useful and becoming counsel... and very wisely tells the soldiers to oppress no one, but be content with their wages" (Ignio Giordani, The Social Message of Jesus qtd. in Webster and Cole 65). St. Ambrose when considering this passage focused on the part the virtue of mercy plays, and he enjoins Christian soldiers to be marked by the virtue of mercy, for they should be soldiers only because they desire to protect their neighbours from harm (qtd. in Webster and Cole 128). This idea of a soldier as an instrument of mercy and love (caritas), which are also the gifts of the Holy Spirit, would become the dominant Christian just war view of the Roman Catholic Church. Ambrose conceived of charity as the motivation for the Christian soldier's use of force. Augustine also concurred that this passage is not a prohibition on soldiering:

For if the Christian religion condemned wars of every kind, the command given in the gospel to soldiers asking counsel as to salvation would rather be to cast away their arms, and withdraw themselves wholly from military service; whereas ... the command to be content with their wages manifestly impl[ies] no prohibition to continue in the service. (qtd. in Webster and Cole 65) 


\section{Jesus and Military Imagery}

Jesus himself uses military imagery in his teachings, for example, in the parable of the king preparing for war (Luke 14:31-33). In Matthew 10:34, Jesus says "I have not come to bring peace, but a sword", and in Luke 12:51, he says "Do you think I came to bring peace on earth? No, I tell you, but rather division!" The word "sword" may have been used metaphorically to refer to the persecution that the disciples and followers of Jesus would have to endure as a result of their faith (Webster and Cole 61). Luke 22 however is more problematic to interpret figuratively:

He said to them, "When I sent you out without a purse, bag, or sandals, did you lack anything?" They said, "No, not a thing." He said to them, "But now, the one who has a purse must take it, and likewise a bag. And the one who has no sword must sell his cloak and buy one. For I tell you, this scripture must be fulfilled in me, "And he was counted among the lawless'; and indeed what is written about me is being fulfilled." They said, "Lord, look, here are two swords." He replied, "It is enough." (Luke $22: 35-38)$

Webster and Cole note that this may represent approval of the use of force by the disciples in self-defence, however, they also point out that two swords would have been completely inadequate for proper resistance. Further, the stories in the Acts of the Apostles depict the disciples as accepting persecution peacefully if they encountered resistance while preaching (see Acts 4:25-31, 8:1-3, 9:1-2, 12:1-5). Matthew Henry's commentary states that Jesus is being ironic, because in reality, two swords are sufficient for those who need none, because they have God as their defence. This might be a better interpretation in the light of the fact that, on the same night, Jesus is arrested in the garden, but he chastises Peter for drawing a sword. 


\section{The Unbelting of Peter}

After the arrest of Jesus, Peter drew his sword and cut off the ear of the high priest's servant. Jesus admonishes Peter saying "Put your sword back into its place, for all who take the sword will perish by the sword" (Matthew 26:52). One explanation for Jesus' words is that he disapproved of Peter coming to his defence because his mission was to die, as Scripture had prophesied since in John 18:11, Jesus says, "Put your sword back into its sheath. Am I not to drink the cup that the Father has given me?" The emphasis here seems to be that Peter's judgment was rash, as there was no justification for his actions. In fact, the words of Jesus following the admonition further emphasise that Peter's behaviour was rash because it interfered with a divinely orchestrated plan: "Do you think that I cannot appeal to my Father, and he will at once send me more than twelve legions of angels? But how then would the scriptures be fulfilled, which say it must happen in this way?" (Matthew 26:53-4).

A related interpretation is one that sees Jesus as condemning the use of the sword at that particular time. However, the words "for all who draw the sword" may seem to imply a blanket prohibition for all use of weapons. The pacifist Tertullian argued that in unbelting Peter, Jesus unbelted every Christian (qtd. in Mattox 147). For Augustine, these words of Jesus were not an interdiction against Christian participation in war, but rather a caution that when one seeks to bring harm to another, there is always a worse harm that happens to the person inflicting the harm:

So also a rash judgment frequently does no harm to him who is the object of the rash judgment; but to him who judges rashly, the rashness itself must necessarily do harm. According to such a rule, I judge of that saying also: 'Every one who strikes with the sword shall perish with the sword.' For how many take the sword, and yet do not perish with the sword, Peter himself being an instance! (qtd. in Mattox 144) 


\section{The Sermon on the Mount and Lex Talionis}

John Mattox states that no single source document wielded greater influence on the development of Augustine's just war theory than did this sermon. The Sermon on the Mount was not some secret or private teaching to the disciples, but was intended for a mass audience. Jesus could have been sure that his message would be disseminated to the masses through the many witnesses who were present. Therefore, the Sermon seems to be a clear and unambiguous example of Jesus' social message and moral teaching as it applied in this world (see Lindberg 5-6). The Matthean Gospel narrative places the Sermon at the front and centre of its account of Jesus' life and as a summary of his main teachings, including his political teachings (Lindberg 10).

The Sermon begins with the Beatitudes which describe those who are truly fortunate and lucky, but rather than describe rulers, priests and the rich, Jesus describes the common people, the poor, downtrodden and persecuted, emphasising that it is not worldly success or adherence to the letter of the law that will determine either the potential of people to live rightly in society or their worthiness in the eyes of God, but rather the inward disposition of people (Lindberg 12).

1. Blessed are the poor in spirit, for theirs is the Kingdom of Heaven.

2. Blessed are they that mourn, for they will be comforted.

3. Blessed are the meek, for they will inherit the earth.

4. Blessed are those who hunger and thirst for righteousness, for they will be filled.

5. Blessed are the merciful, for they will receive mercy.

6. Blessed are the pure in heart, for they will see God.

7. Blessed are the peacemakers, for they will be called children of God.

8. Blessed are those who are persecuted for righteousness' sake, for theirs is the kingdom of heaven.

9. Blessed are you when people revile you and persecute you and utter all kinds of evil against you on my account. Rejoice and be glad, for your reward is great in heaven, for in the same way they persecuted the prophets who were before you. (Matthew 5:3-12) 
Out of the nine beatitudes, the first, sixth, eight and ninth seem to refer to rewards in the next life, however, the others seem equally grounded in this world as well as the next. One explanation for this is that the conditions Jesus seeks to change (viz. those who are arrogant or haughty (the first beatitude), those who are not pure in heart (sixth), those who persecute (eight and ninth)) will simply not exist if Jesus' teachings are taken to heart. The other conditions, however, (viz. those in mourning, the gentle, those who desire righteousness, those who act out pure intentions and those who seek peace) will always exist. Jesus' political agenda, therefore, is organised around the pursuit of righteousness by those who are able for the sake of a world in which the unvalued are fully valued as human beings (Lindberg 31).

The Beatitudes do not merely offer consolation to the downtrodden. They are also a guideline for good behaviour. They do not only describe rewards in the afterlife, but also offer warnings (for Jesus' society and for our own) that change was imminent for those who enjoyed privilege without righteousness. Augustine regards the Sermon on the Mount as "a perfect code of morals" (see Mattox 133). This sermon contains many of Jesus' sayings concerning one's response to violence. Jesus enjoins his followers saying:

You have heard that it was said, 'An eye for an eye and a tooth for a tooth.' But I say to you, Do not resist an evildoer. But if anyone strikes you on the right cheek, turn the other also; and if anyone wants to sue you and take your coat, give your cloak as well; and if anyone forces you to go one mile, go also the second mile. Give to everyone who begs from you, and do not refuse anyone who wants to borrow from you. (Matthew 5:3842)

Lindberg says that although the law of the tooth, or lex talionis seems like harsh punishment, it was an improvement on not having such a law, as not having such a law meant that people would exact greater punishment for those who have wronged them, 
even death for the wrongdoer or perhaps for their entire family for infractions such as theft of livestock or horses. This only leads to a vicious cycle of violence and a "war of all against all" as Hobbes would describe it. One way of breaking this cycle was through the ruler. However, this ruler first had to establish a degree of acceptance of his position by his subjects. One way of thwarting challenges to his rule is by providing his subjects with a way to settle disputes through a set of general principles, in other words, instituting the law. The lex talionis was a kind of moderating principle as well as a law proportional retaliation for wrongdoing. Jesus does not abolish the ancient law, but rather, he builds on it. Note that Jesus does not say that if someone tries to kill you, you should let him or her kill the rest of your family as well. The offenses that Jesus lists appear to be less serious. A slap on the cheek is not so much a physical injury as it is a slap to one's pride. If you do not retaliate at all, you might be seen as a doormat, as one who suffers unjust insults without retaliating. However, by advising one to offer the other cheek, Jesus is attempting at restoring the dignity of the slapped person. There is no obligation to respond in kind, but as a free person, offering the other cheek does not show passivity but defiance and this reaffirms the dignity and the freedom of the injured person. What Jesus is doing in this teaching is reminding us to look inside to find our freedom, but he also wants the activity of this inner freedom to have a positive effect on the world. By reacting in the way Jesus suggests, it exposes the evil of the wrongdoer. It offers an example of right conduct to the wrongdoer and it may induce shame in the person striking (Lindberg 56-61).

For Augustine, an eye for an eye is not Jesus saying that you cannot retaliate, only that the retaliation not exceed the injury. Not resisting evil, (which for Christian pacifists 
seemed to support the idea of complete pacifism), for Augustine, had a very specific meaning: it is not so much the bodily action of retaliation that is required, but rather, an inward disposition (Mattox 134). Physically resisting violence against oneself is less important than avoiding evil which can do violence to the soul. Turning the other cheek is not a command to suffer injustice, as Augustine questions:

For who would submit to have anything taken from him by an enemy, or forbear from retaliating the evils of war upon an invader who ravaged a Roman province? [...] These precepts pertain rather to the inward disposition of the heart than to the actions which are done in the sight of men, requiring us, in the inmost heart, to cherish patience along with benevolence, but in the outward action to do that which seems most likely to benefit those whose good we ought to seek" (qtd. in Mattox 134).

Augustine uses the actions of Jesus as his example: when Jesus was struck on the cheek by the temple guard, he did not offer the other, but demanded that the guard justify striking him for he had done nothing wrong (John 18:12). Mattox points out that we can characterise all actions of Jesus showing resistance as following under Augustine's rubric of balancing pacifism and violence: Jesus is passively non-resistant at his crucifixion, non-violently resistant at his trial, and violent within appropriate means when cleansing the temple. It is this same kind of balance that Augustine demands of Christians if they are engaging in violence (Mattox 135). He demands that they fight in a spirit of benevolence, but even if they do not fight benevolently, as long as the commonwealth observe Christian teachings, "after the resisting nations have been conquered, provision may be more easily made for enjoying in peace the mutual bond of piety and justice" (qtd. in Mattox 136).

How then does Augustine view Jesus' blessing: "Blessed are the peacemakers: for they will be called children of God" (Matthew 5:9)? Although not the last beatitude, 
Augustine attempts to explain how all the other beatitudes lead to this one. He even applies it in his just war theory: "even in waging war, cherish the spirit of a peacemaker, that, by conquering those whom you attack, you may lead them back to the advantages of peace" (qtd. in Mattox 152). So while prizing peace, Augustine is still no pacifist. He permits Christian rulers to declare just wars and Christian soldiers to participate in wars; before Constantine, there were no politically relevant Christian rulers to speak of, and ostensibly, no true just wars. It was an identification of the new Christian empire with the kingdom of God on earth that required a new way of thinking and new justifications.

\section{The Bible and Respect for Authority: Render unto Caesar}

Another criterion in the political idea of the just war is that a war must be declared by a legitimate authority. As James Dougherty writes, "Christ taught no specific theology of politics except to assert that political power comes from God, that His kingdom is distinct from all earthly states, and that man owes obedience to two distinct jurisdictions, but must obey the higher in case of conflict" (19). This can be seen from the passage from Mark where Jesus is asked by the Pharisees and Herodians who wanted to trap him whether it is lawful to pay taxes to the Emperor. Jesus responds by asking them to show him a denarius: "And they brought one. Then he said to them, 'Whose head is this, and whose title?' They answered, 'The emperor's.' Jesus said to them, 'Give to the emperor the things that are the emperor's, and to God the things that are

God's.' And they were utterly amazed at him" (Mark 12:16-17). Jesus' answer is a coded response - a witty aphorism which avoids giving offence. However, this passage 
seems like a precursor to the words of Paul ${ }^{16}$ because in it, Jesus seems to be teaching that giving allegiance to earthly kings is good for earthly matters, but for spiritual matters, God is the only true authority. This passage sets up the idea of legitimate authority in the just war doctrine, but not as explicitly as in the Epistles of Paul.

\section{The Epistles of the Early Church Leaders}

Chapter 13 of the Pauline letter to the Romans has often been used to justify Christian support for war. Rowland says that any interpretation of this chapter must begin with the one that precedes it in which Paul offers an outline of Christian polity that centres on renewal of the mind and the leading of a sacrificial life in the interim before Christ's coming again to rule the earth.

Let every person be subject to the governing authorities; for there is no authority except from God, and those authorities that exist have been instituted by God. Therefore whoever resists authority resists what God has appointed, and those who resist will incur judgment. For rulers are not a terror to good conduct, but to bad. Do you wish to have no fear of the authority? Then do what is good, and you will receive its approval; for it is God's servant for your good. But if you do what is wrong, you should be afraid, for the authority does not bear the sword in vain! It is the servant of God to execute wrath on the wrongdoer. Therefore one must be subject, not only because of wrath but also because of conscience. For the same reason you also pay taxes, for the authorities are God's servants, busy with this very thing. Pay to all what is due them-taxes to whom taxes are due, revenue to whom revenue is due, respect to whom respect is due, honour to whom honour is due. (Romans 13:1-7)

\footnotetext{
${ }^{16}$ Note that when I refer to the Gospels or the epistles as being works of the author ascribed by tradition, I do not mean that a particular author wrote those words. In modern Biblical exegesis, it is well understood that, for example, Jesus' disciple Matthew did not write the Gospel according to Matthew, but that this is probably a compilation from various sources written in the name of Matthew. Likewise, many of the epistles attributed to Paul are now recognised as compilations of various letters, some not by Paul. Most Bible books are seen as being pseudoepigraphal although they are still referred to by the names of the authors attributed to them.
} 
This passage serves to highlight the fact that unlike Jewish thought in which the only just wars are those specifically commanded by God, because the ruling authority (of earthly princes) is derived from God, wars to defend righteousness could be waged by earthly rulers without an express divine command. However, this explanation is not as clear-cut. For example, Acts 5:29 appears to contradict being subject to government authorities: "We must obey God rather than any human authority." A more nuanced interpretation is that the Christians are to subject themselves to government authorities on issues of morality on which specific pronouncements by God have not been made, but that the laws of God would always trump. ${ }^{17}$ Also, in light of Romans 13:6-7, the context of subjection to government authority may be with respect to the payment of taxes, not with blind obedience to a state-defined morality.

The first part of the passage clearly states that "the authorities that exist have been established by God." This is not problematic if the war in question is a civil crisis, since there is only one authority - the established state government. In a context of interstate war however, both the authority of the state(s) claiming moral superiority as well as the authority of the state(s) whose morality is being questioned have been established by God. This leads to any war as being a war against an authority established by God. Further, it makes God somehow responsible for the activities of despotic or morally unsound governments, since He established these authorities. In any case, using Romans 13 as a justification for war seems tenuous at most. At the most, an argument can be made that St. Paul, as a citizen of Rome, does view the Roman government as directly,

\footnotetext{
${ }^{17}$ This kind of explanation is also supported by the early Church Fathers. For example, the early secondcentury patristic text, Martyrdom of Polycarp 10.2 states: "Christians ought to render honour to rulers except when it does themselves harm" (Webster and Cole 62). A similar injunction is found in the late second-century text Against Heresies 5.24.2 by St. Irenaeus of Lyons (Webster and Cole 62).
} 
although perhaps unknowingly, serving the will of God because as he says in verse 4 , they do not bear the sword for no reason. The time this text was written, around $55 \mathrm{CE}$, was well before the persecution of Christians by Nero (that was to result in Paul's death), and Paul was still optimistic about the potential good of the Roman government and military (Webster and Cole 63). Perhaps further clarification can be found in Paul's letter to Titus where the author writes:

Remind them to be subject to rulers and authorities, to be obedient, to be ready for every good work, to speak evil of no one, to avoid quarrelling, to be gentle, and to show every courtesy to everyone. For we ourselves were once foolish, disobedient, led astray, slaves to various passions and pleasures, passing our days in malice and envy, despicable, hating one another. (Titus 3:3)

Here, the author specifies that in being subject to rulers and authorities, it must be for what is good. It can be inferred that being obedient and doing good is something that rulers and authorities are supposed to enforce because if not, people will be slaves to their own whims and society will cease to function. Paul also writes to Timothy reinforcing the idea that obeying kings is following the will of God: "Also I urge, then, first of all, that petitions, prayers, intercession and thanksgiving be made for all people - for kings and all those in authority, that we may live peaceful and quiet lives in all godliness and holiness" (1 Timothy 2:1-2). It is implied that it is for good authorities and for good rule that people pray, not for despots or tyrants. The first Epistle of Peter further brings home the point that one should only submit to those authorities who do good and do God's will because they are sent by God: 
For the Lord's sake accept the authority of every human institution, whether of the emperor as supreme, or of governors, as sent by him to punish those who do wrong and to praise those who do right. For it is God's will that by doing right you should silence the ignorance of the foolish. As servants of God, live as free people, yet do not use your freedom as a pretext for evil. Honour everyone. Love the family of believers. Fear God. Honour the emperor. (1 Peter 2:13-17)

\section{Pacifism or Just War? The Choice of Early Church Leaders}

If anything, it can be seen from the above passages that a superficial reading of the texts yields merely ambiguity with respect to warfare in the New Testament, which is why Christian writers accommodated Biblical precepts to the Hebrew and Roman examples of holy and just war (Russell, The Just War 11). When Christianity was trying to define itself as a religion, the task of determining the role of politics proved a challenge. While the Jewish Bible is replete with accounts of war and examples of how a code of warfare is to be applied, the New Testament contains neither accounts of battles nor codes of warfare. Moreover, the Old Testament world of a theocratic nation of Israel no longer existed being replaced by the Roman Empire, and Christians felt compelled to choose between allegiances to the Church and the Emperor. The New Testament also seems to exhibit a shift in thinking with Jesus' new dispensation that it is not the letter of the law and outward expressions of faith that are paramount (e.g. not doing work on the Sabbath, not having to keeping the dietary laws of Kashrut, not allowing divorce), but rather, one must examine more one's true intentions and spiritual motives (see Mattox 131-32).

Christianity originally started off with the pacifist message, which is seen to arise from the Sermon on the Mount (Ravitzky 123). It was believed that one could not be a 
soldier of Christ and a soldier of the Emperor at the same time. For this reason, the age before about $320 \mathrm{CE}$ is referred to as the age of Christian doves when one looks at the writings of Justin Martyr, Irenaeus of Lyons, Clement of Alexandria, Origen, Cyprian, Lactantius and Tertullian (Hazlett 121). Clergy condemned all warfare, especially Roman wars. They rejected military service in favour of the militia Christi - a pacific struggle against evil. Church father Origen (c.185-c.254) argued that Jesus' message was one of non-violence, and that Christians have a spiritual vocation to support the emperor and fight his enemies by prayer to God rather than through military service. Priests and the religious were especially enjoined against engaging in battle. In fact, participation in political matters, even for the maintenance of the laws and the support of religion was discouraged because the rule of the Church (in accordance with the Word of God) was seen as far more pertinent and important to the life of a Christian than state matters (A.F. Holmes $^{18}$ 48-50). Origen described the Old Testament wars authorised by God as necessary for Jewish kingdoms, but since wars were no longer permitted by Christ, God allowed the kingdoms to disintegrate (Russell, The Just War 11). "Origen considered the Old Testament as an allegory of the New, consequently Christians should study the historical books of the Old Testament with the understanding that these wars should be understood as spiritual wars against the devil. They functioned as exempla for moral edification rather than as guides for making decisions" (Russell, The Just War 11). Lactantius (c.250-c.330) echoes this commitment to non-violence but also has a marked disdain for the state. The evolution of human society from cave to village and later to city and state is almost abhorred as the "foolish trifle" of "wretched and pitiable men"

\footnotetext{
${ }^{18}$ This text contains various short excerpts from vast number of original texts, but my page numbers will refer to the Holmes text although Holmes is quoting the original source.
} 
and "the greatest impiety" (A.F. Holmes 53) because ultimately this separates man from man, whereas God created man as one collectivity. As a minority religion, the keystone to church teachings was a renunciation of this world. Christianity was not seen as being concerned with having an influence on public policy or in participation in the activities of the State - Christians could not serve two kingdoms - Christ's and Caesar's. Most Christians did not hold public office. As a result, most Christians were marginalised. They were viewed as atheists and disloyal citizens, subversives and enemies of the State since they thwarted existing Roman cultural and spiritual norms (Hazlett 121). ${ }^{19}$

However, it was with the Emperor Constantine's support of Christianity on the eve of battle in $312 \mathrm{CE}$, and after Christianity became the official religion of the Roman Empire that the "just war" doctrine began to develop. This era represented a transition from Christian non-participation to Christian political involvement. Constantine employed Christian symbols such as the Chi-rho on Roman army shields and in 325, he presided over the Council of Nicaea which helped solve discrepancies on articles of Christian faith, in particular, it solidified the theandric nature of Christ as both fully human and fully divine. Being Roman and being Christian became synonymous, and the Emperor came to be viewed as the guarantor on earth of the triune God. This marked the

19 Adolf von Harnack in his book Militia Christi: The Christian Religion and the Military in the First Three Centuries lists eight reasons, which may have influenced early Christianity's rejection of war. What this list illustrates is that there may have been other factors besides just an aversion to warfare on moral grounds: (1) it was a warrior's profession, and Christianity on principle rejected war and the shedding of blood; (2) the officers, under given circumstances, had to pass the sentence of death, and the soldiers in the ranks had to carry out everything they were ordered to do; (3) the unconditional oath required of the soldier was in conflict with the unconditional obligation to God; (4) the cult of the emperor was at its strongest in the army and was hardly avoidable for each individual soldier; (5) the officers had to offer sacrifices, and the regular soldiers had to take part; (6) The military standards appeared to be heathen sacra; to reverence them was hence idolatry (in the same way, military decorations - wreaths and so forth - seemed idolatrous); (7) the conduct of soldiers in peacetime (their extortions, loose morals, and so forth) conflicted with the Christian ethic; and (8) the traditional rough games and jokes in the arms, for example, the mimus, were offensive in themselves and were connected in part with the service of idols and the festivals of the gods (qtd. in Mattox 141). 
end of a commitment to pacifism (Hazlett 122). The peace that Constantine maintained within the Empire and his many benefactions to the Church may have influenced Christian theologians to accommodate Roman wars. Rome had a tradition of just war from the time of Cicero (106-43 BCE), who defines wars as just if they are undertaken for defence of honour or for safety. He also states that wars without provocation are unjust and that only war waged for revenge or defence could be just. Also, to be considered just, a war must be proclaimed and declared, or reparation must first be demanded (A.F. Holmes 25). Many of these elements later found their way into Christian formulations. Constantine's bishop and advisor, Eusebius of Caesarea, identified the Roman Empire with the divine peace-keeping mission. He developed two forms of Christian vocation: the laity had to shoulder the burdens of citizenship and wage just wars, while the clergy was to remain outside of society and dedicated solely to God. Thus, the participation of Christian laity in Roman wars was now approved (Russell, The Just War 12).

\section{St. Ambrose of Milan - the Precursor to Augustine}

It is St. Ambrose (c.339-397) who marks a distinct Western Christian approach to the problem of war (Webster and Cole 122). By the time Ambrose arrives on the scene, Christians are beginning to participate in the political life of the Empire, which they had not done in pre-Constantinian times. Ambrose recognises the necessity of war for the sake of a secure peace, but denounced needless bloodshed, introducing the two ideas that make the Western Christian just war doctrine Christian: "the role of charity, which compels justice, and the role of ecclesiastical discipline in keeping just war just" 
(Webster and Cole 123). Military matters were matters of Empire. In the Empire, there already existed elements of certain jus in bello rules. For example, the Christian is charged with showing compassion to his enemies (A.F. Holmes 55).

After the Edict of Thessalonica in 381, Christianity became the official religion of the Empire. Legislation obliged the government to defend the teachings of the Church from heresy, and ultimately, heresy was assimilated with the crime of treason, thus sowing the seeds of animosity between believer and unbeliever. Ambrose himself, before becoming a bishop, held a high government office, and thus recognised the necessity of political order for the Empire to prosper. He wrote "Man was made for the sake of man" therefore, "in accordance with the will of God and the union of nature, we ought to be of mutual help to one another, and to vie with each other in doing duties" (qtd. in Webster and Cole). Ambrose prayed for the success of Roman armies, because he saw them as defending the Empire from thieves. Roman defeats came to be viewed as punishment for sin, and war as punishment for sinners. He viewed the government as a divinely created institution that allows for political order which will allow man to live in mutual cooperation. The Emperor, as the ruler of the Empire had a divine duty to preserve this order, which, for Ambrose, included safeguarding the Church. The duty that the Emperor owed to God was through the auspices of the Church. As he tells the Emperor Valentinian: "You are also in the service [militatis] of almighty God and of our holy faith" (qtd. in Webster and Cole 123). In his epistle to the emperor Theodosius chastising him for the massacre of innocent civilians at Thessalonica, Ambrose subjects the actions of the Emperor to ecclesiastical control. According to Ambrose, the Emperor is not responsible directly to God, but rather, the use of the sword by the state is not entirely 
outside of the Church's sphere of authority if the state authorities are also Christians. Ambrose reminds Theodosius that any victories that he has obtained are only because God made it possible, therefore, he cannot ignore the Church because the foundation and security for order in public matters comes from the Church. Abandoning the Church would have serious consequences and would compromise the chances of military victory for the emperor. It is this requirement of the Christian Emperor to heed the guidance of the Church that leads to a distinctively Christian understanding of the exercise of military power by the state.

For Ambrose, the Old Testament heroes offer examples of the virtuous warrior. He describes Moses as a just warrior who “... feared not to undertake terrible wars for his people's sake, nor was he afraid of the arms of the mightiest kings, nor yet was he frightened at the savagery of barbarian nations. He put to one side the thought of his own safety so as to give freedom to the people" (qtd. in Webster and Cole 129). King David was the exemplar of the just and virtuous Christian ruler. Some of his virtues that were to be emulated included not entering war without seeking the counsel of God, waging war only when necessary, and entering wars with prudence combined with fortitude (Webster and Cole 126). In On Duties, he lists three jus in bello rules for Christian soldiers: (1) no unfair advantage of the enemy should be taken (1.29.139); agreements with the enemy should be kept (2.7.33), and (3) mercy should be accorded a foe in defeat (3.14.87) (qtd. in Webster and Cole 126).

Ambrose, however, forbids civilians from taking up arms, even in self-defence: "I do not think that a Christian, a just and a wise man, ought to save his own life by the death of another; just as when he meets with an armed robber he cannot return his blows, 
lest in defending his life he should stain his love (pietatem contaminet) toward his neighbour" (qtd. in Webster and Cole 130). This would also influence Augustine's thinking with respect to civilians and war. Clergy too are prohibited from taking up arms since the "thought of warlike matters seems to be foreign to the duty of our office, for we have our thought fixed more on the duty of the soul than on that of the body; nor it is our business to look to arms, but rather to the affairs of peace" (qtd. in Webster and Cole 131). The Church was supposed to fight not "with temporal arms but with the arms of the spirit" (qtd. in Webster and Cole 131). It was soldiers who had the duty to protect the innocent with force; the clergy's duty was to pray for success of that force and to be willing to abstain from violence when attacked.

Ambrose, thus combines Roman and Christian morality, by supporting just wars by reference to the Old Testament. The cause of the war must be just, as were the divinely ordered wars of the Old Testament. However, the Roman rules of warfare, fidelity, and respect for the enemy's rights, were also to be maintained (although such rules seem to be relaxed when dealing with heretical barbarians) (Russell, The Just War 13-15). This illustrates how a grounding of the just war doctrine based on both Old and New Testament moral principles was still lacking.

\section{Christian Attitudes towards War during the time of Augustine}

The Christian Empire which replaced the pagan one was seen as the realisation of the Kingdom of God on earth. The Pax Constantini brought the Church out of hiding in the catacombs into positions of power in the Roman Empire. However, Augustine lived in the declining days of this Christian Roman Empire (354-430). The migrations of 
barbaric peoples from northern Europe and Central Asia were the Empire's single greatest challenge. Civil war within the provinces of the Empire was common. North Africa was being threatened by Vandals, and Augustine lived through the sacking of many North African cities and churches by the Vandals. And as he was dying, the city of Hippo where he was bishop, was besieged by Vandals. In order to respond to those who claimed that it was Christianity that caused the collapse of the Empire, Augustine wrote The City of God Against the Pagans - a text from which philosophers who proceeded him would further develop a Christian theory of just war. Augustine's main argument was that Rome was never truly Christian and never truly just because pagan worship continued. In fact, no earthly state can have true justice, but only some relative justice. Augustine defines justice by starting with the traditional definition of giving every man his due, but grounds it in Christian philosophical commitments arguing that true justice lies in loving and serving God only. Therefore for a state to have true justice, it must be truly Christian (Mattox 23-25).

One of the reasons that a state cannot have true justice is due to the fact that Original Sin makes all humans guilty of acting contrary to what we know to be right. Some individuals have earthly power and possessions as the object of their love, while others love things that are associated with a heavenly reward. These are the citizens of the earthly city and of the City of God respectively, and both kinds of citizens are found in society. The City of God will only triumph when the earthly city is no more. However, the mixed citizenship on earth will never realise that their best interests lie in peace and harmony; rather, it is those who desire for glory and domination who incline the people to war. Mattox says that "[I]f anything, Augustine's world-view that features 
good and evil people thoroughly intermixed occasions a more pressing need than ever for a theory to make sense of the claim that such people could ever fight a just war" (29). Therefore, there is a real futility in Augustine's theory, because the ultimate goal of the Christian to align his will with the divine will is unattainable in this life. There is no lasting peace or security possible in the here and now. Earthly peace, like the Pax Romana is only temporary in comparison to the eternal Pax Christi (Hazlett 128).

When Constantine embraced Christianity, by Augustine's reasoning, if the ruler of an empire were Christian, the possibility for justice existed. The institutional Church was allied with the emperor, and, because of this connection, any wars that were waged by the state allied with the Church were at least viewed as more just than the wars waged by non-allied states. Many Church Fathers did view the triumphs of Rome as being the will of God (Mattox 29). Indeed, Augustine argued that if Christianity were adhered to by Rome it would "enlarge the commonwealth in a way beyond all that Romulus, Numa, Brutus, and all the other men of renown in Roman history achieved" (qtd. in Mattox 30). Embracing Christianity did not guarantee justice, but, for Augustine, it offered a possibility that justice would be properly pursued: more just wars would be fought using more just methods.

In order to have justice, man had to serve God, and the only object worthy of love is God, therefore to truly be a "people" individuals must be bound together by higher interests because only God and the law of God can truly command the soul and reason. The soul and reason by themselves are incapable of controlling the vices. Augustine cites David and Moses from the Old Testament (who were commanded by God to fight), soldiers being baptised by John and a centurion from the New Testament whom Jesus 
does not instruct to change his profession as examples of a tacit approval for soldiering. He has no problem approving of violence towards "him who rebels and resists", but advocates showing mercy to "the vanquished or the captive" (A.F. Holmes 63). He argues that Christ's command to turn the other cheek is an inward disposition rather than a bodily action (A.F. Holmes 61-65). According to Augustine, it is not war-making that the Bible prohibits, but the violence, cruelty and lust for rule that accompany war (Russell, The Just War 16). As Ravitzky argues:

Augustine, the chief spokesperson for this [just war] doctrine, buttressed his arguments by citing the sayings of the prophets in their literal, original senses; the pacifist verses in the New Testament, however, had to be given a new, nonliteral interpretation. Here too, this was done by way of spiritualization - not, however, of texts that called to battle, but of those that rang with pacifism. The latter were interpreted as referring to man's inner state, to the depths of his spirit, and not to concrete historical reality. $(124-25)$

Regarding authority, Augustine has God as the highest authority that might compel men to engage in war. The monarch is also delegated a legitimate authority to wage war for the safety and peace of the community (A.F. Holmes 65, see Augustine, CofG Bk. 1, Ch. 22) and all this must be in obedience to God. He reasons that soldiers are to have impunity because they are following orders from a higher authority - the King. This idea has its roots in Romans 13: a person who kills out of obedience to a divine authority does not himself kill, but is an instrument of God's will. Even if the King is misguided or ungodly, since obedience is the duty of a soldier, he is still morally innocent. In some ways, war is cited as something that brings people together, because they become more unified within the Empire, and an imposed common language may also strengthen a bond of peace between people (A.F. Holmes 71). For Augustine however, a perfectly ordered peace can only be found in the heavenly city. He says 
"there may be peace without war, but there cannot be war without some kind of peace, because war supposes the existence of some natures to wage it, and these natures cannot exist without peace of one kind or another" (qtd. in A.F. Holmes 71). Even things that are evil (including the nature of the devil himself) have some good. He notes that war is temporal, and that periods of war also give way to periods of peace, which may be longer than those periods of war, but nonetheless, these conditions are finite and they necessarily shall pass away (see A.F. Holmes 79). He says that "the earthly city, that does not live by faith, seeks an earthly peace", achieved usually by "the combination of men's wills [read: commonwealth] to attain the things which are helpful of this life" (qtd. in A.F. Holmes 78). In other words, the state system itself is a result of the imperfection of the earthly plane whose imperfection originates in the Fall of Adam, for the heavenly city has no such seemingly arbitrary “diversities” (A.F. Holmes 79).

So after rationalising that wars are a necessary side-effect of the human condition as a result of the Fall, and then determining that the King is a legitimate authority for declaring war, Augustine still had to deal with the New Testament precepts of "turn the other cheek' (Matthew 5:29) and 'leave room for the wrath of God' (Romans 12:19). He developed the doctrine by which war, broadly described as the punishment of a sinner, was motivated by love of the sinner (Russell, The Just War 57). Augustine thus transformed the Christian notion of love (caritas) into a motivation for waging war. A private citizen or cleric, however, could not kill an attacker, even in self-defence, since this would entail loss of love. Therefore, the pacifism of the early Church still extended to civilians. Because state leaders had the sole authority to make war, the need for legitimate authority was later emphasised as necessary to wage a just war. The actual 
justification of war came from the need to avenge injuries, or to punish wrongs by members. This seems similar to the Ciceronian view that the aims of the just war are to address grievances and secure compensations for loss, and to return the aggrieved part to the status quo ante bellum. However, Augustine went further, since his definition of justice extended beyond simple legal rights and included a respect for divine rights. Therefore, the justification of war was also made possible in cases where Christian law, or Christian orthodoxy or the rights of Church hierarchy were violated. This eventually paved the way for the Crusades which synthesised holy war with the just war (Russell, The Just War 19-26, 38). Church canon law would eventually come to codify the support of the Church for combat against heretics, excommunicates, enemies of the peace and infidels. Around 1085, Anselm of Lucca published the Collectio Canonum which justified coercion against the enemies of the Church. The Crusades, being directly authorised by the Pope became the Church's ultimate just war (Russell, The Just War 3839). The Crusades will be discussed further later.

\section{Augustine's Just War Criteria}

\section{Just Cause}

The most important requirement is that the cause be just. Some examples that he offers are wars which "avenge injuries, if some state against whom one is waging war has neglected to punish a wrong committed by its citizens, or to return something that was wrongfully taken" (cf. Psalms 46:9; Psalms 68:30; Isaiah 2:4; Habakkuk 2:12). He expands Cicero's definition of the just war. Cicero justified war if it was "limited in its aims to securing redress of grievances and compensation for losses occasioned by crimes 
of the offending party to the persons, property (res) or rights (iura) of the aggrieved party" (Russell, The Just War 18, 19). Cicero's goal for the war was much like tort remedies in the Common Law - a return to the status quo ante bellum. However, Augustine seems to add punitive damages as well, and compensation, not just a return to the status quo ante bellum. Mattox explains that Augustine's definition includes not only material compensation for property unjustly taken or destroyed but moral compensation an admission of wrongdoing or immoral conduct. The moral code that Augustine uses is a Christian one. This has the effect of enlarging the just war to include wars not only for personal grievances, but spiritual ones, like wars against idolatry. This punitive and spiritual element of Augustine can easily be seen in Augustine's Reply to Faustus the

\section{Manichaean:}

What is the evil in war? Is it the death of some who will soon die in any case, that others may live in peaceful subjection? This is mere cowardly dislike, not any religious feeling. The real evils in war are love of violence, revengeful cruelty, fierce and implacable enmity, wild resistance, and the lust of power, and such like; and it is generally to punish these things, when force is required to inflict the punishment, that, in obedience to God or some lawful authority, good men undertake wars, when they find themselves in such a position as regards the conduct of human affairs, that right conduct requires them to act, or to make others act in this way. (qtd. in Mattox 47)

Augustine makes no distinction between offensive and defensive wars. He clearly supports the defensive wars of Rome because they were defending the Empire. However, he also supports wars as punitive actions. These are, in their nature, not defensive. However, overtly offensive war would have to be ordained by God, such as the wars that God authorised in his command to Moses, Joshua and other figures especially in the Hebrew Bible. However, for Augustine, political sovereigns can serve as a proxy for divine authority since God has permitted them to reign, and therefore, their decisions 
reflect the divine will (see Mattox 48). However, even when wars are caused by direct divine command, Augustine points out that the Bible provides examples of the injustices caused by the perpetrators that God was trying to correct through war, thus inferring that these Old Testament wars were also punitive in nature (Mattox 51).

Augustine's neo-Platonism allows him to equate justice with order. His Christianity reflects this idea of order that the objects of one's love be properly ordered. He determines what would qualify as a just war by uniting both justice and order. Augustine characterised the failures and successes of the Roman Empire thusly: Rome did gain divine favour, however, it worshipped glory and not God as the proper object of worship. The proper question to consider before engaging in war is "whether going to war would be reflective of a proper ordering of the nation's ruler's loves" (Mattox 148).

\section{Comparative Justice}

Augustine states, "Now when the victory goes to those who were fighting for the juster cause, can anyone doubt that the victory is a matter for rejoicing and the resulting peace is something to be desired" (CofG XV.4, 600). Therefore, while both sides can claim to be just, Augustine says that "it is the injustice of the opposing side that lays on the wise man the duty of waging wars" (CofG XIX.7, 862). Mattox explains however that these references in Augustine's work refers to the justice (and subsequent peace and order) of the Roman Empire against the injustice of invading barbarians, in which case, it was obvious which side was more just. At the same time, however, if Augustine allows that there could be justice on both sides, and although he considered the Roman wars in defence of patria as just, this was no declaration that Rome was ever absolutely just, but 
at least relatively just (Mattox 53-54). Mattox also points out that Augustine does advocate mercy and forbearance on the part of combatants. This is because even an enemy may be regarded as not totally unjust.

\section{Right Intention}

This is one of the least ambiguous portions of Augustine's analysis. Almost all passages dealing with war deal with intention. A rightly intentioned war is one which is "waged by the good in order that, by bringing under the yoke the unbridled lusts of men, those vices might be abolished which ought, under a just government, to be either extirpated or suppressed" (qtd. in Mattox 54). Some examples of wars that were waged without right intention include wars of territorial expansion.

Ultimately, if everyone acted with the best intention all the time, war could be eliminated. Since this is impossible, those who must wage war must do it with right intention and in the most humane possible way, without taking any delight in engaging in the violence, rather lamenting that it was necessary to conquer injustice. Even if some evil was committed, if the intention of the warring party is good, they would be exonerated in the eyes of God (Mattox 56).

Augustine roots his idea of right intention in Christianity. Attitude and intention is more important for Augustine than the act itself and with respect to war, he states, "It is not military duty (militia) but malice of heart (malitia) that forestalls the doing of good" (qtd. in Mattox 149). It is not sufficient just to claim a good intention in order to transform the evil or unjust act of war into something good, but this claim must be genuine. 
Centuries later, other Christians objected that violence is never commensurable with Christian love. For example, the seventeenth century Quaker Robert Barclay stated:

Whosoever can reconcile this, "Resist not evil" with Resist evil by force; again, Give also thy other cheek, with strike again; also, Love thine enemies, with spoil them, make a prey of them, pursue them with fire and sword; or, Pray for those that persecute you, with persecute them by fines, imprisonment and death itself; whoever can find a means to reconcile these things, may be supposed also to have found a way to reconcile God with the Devil, Christ with Antichrist, Light with Darkness, and good with evil. (qtd. in Mattox 166)

\section{Competent Authority}

Augustine views human governments as being ordained by God for the benefit of Man - a kind of earthly proxy for the divine will. The hierarchy of rulers and ruled, for Augustine, is divinely ordained for he says "when we take into consideration the social condition of the human race, we find that kings, in the very fact that they are kings, have a service which they can render to the Lord in a manner which is impossible for any who have not the power of kings" (qtd. in Mattox 150). One of the exclusive rights of the sovereign is the power to wage war "for the natural order which seeks peace for mankind ordains that the monarch should have the power of undertaking war if he thinks it advisable, and that the soldiers should perform their military duties on behalf of the peace and safety of the community" (qtd. in Mattox 57).

The sovereign in question, of course, has to be just. The citizen owes absolute obedience to the sovereign, including in waging war, with one exception - if the sovereign directs them in a way that opposes the will of God. Augustine gives the example of the emperor Julian whom he calls "an infidel Emperor, an apostate, a wicked man, an idolater" (qtd. in Mattox 57) whom Roman Christian soldiers obeyed in battle. 
However, they refused to obey when they were commanded to worship pagan gods. In this case, the soldiers were not absolved of their military duties. The sovereign, for Augustine, need only answer to God not to his subjects; the duty of citizens is to obey their sovereign: "in obedience to God or some lawful authority, good men undertake wars, when they find themselves in such a position as regards the conduct of human affairs, that right conduct requires them to act, or to make others act in this way" (qtd. in Mattox 58). This seems to imply that there is no room for conscientious objection - the citizen will still have to suffer the consequences of disobeying the sovereign.

Mattox notes that Augustine demands from citizens "an exhortation to obedience to duly constituted authority as part of the unfolding plan of divinely directed history" (Mattox 58). The sovereign is a conduit for God on earth, and all the rights of man in civil society come from God through the sovereign. Augustine likens this authority to the authority of a loving father, who, although he may have to dole out painful discipline to a wayward child, loves the child no less. Similarly, if the commonwealth were Christian, there would still be more peace after the war than if the commonwealth were not Christian. The ultimate objective of war, therefore, is peace. Safeguarding territory or righting past wrongs are merely proximate objectives. If peace can be achieved without war, it is even more desirable:

But it is a higher glory still to stay war itself with a word, than to slay men with the sword, and to produce or maintain peace by peace, not by war. For those who fight, if they are good men, doubtless seek for peace, nevertheless it is through blood. Your mission, however, is to prevent the shedding of blood. Yours, therefore, is the privilege of averting that calamity which others are under the necessity of producing. (qtd. in Mattox 60) 


\section{Proportionality}

In addition to the jus ad bellum criteria, Augustine also elaborates on the conduct of warfare (jus in bello). He advocates the principle of proportionality, whereby the combatants' aim should not be to induce gratuitous suffering, but rather to lead one's enemies "back to the advantages of peace" (qtd. in Mattox 61). He advocates a surgical style of warfare where every attempt should be made to minimise killing:

For he whose aim is to kill is not careful how he wounds, but he whose aim it is to cure is cautious with his lancet; for the one seeks to destroy what is sound, the other that which is decaying... [W] [Wat is important is to attend to but this: who were on the side of truth, and who were on the side of iniquity; who acted from a desire to injure, and who from a desire to correct what was amiss? (qtd. in Mattox 61)

Military tactics such as ambush and deception are legitimate, however, if carried out by people who have the right to do so (i.e. a soldier following orders from a legitimate authority). Augustine states, "Once an individual has undertaken this [just] kind of war, it does not matter at all, as far as justice is concerned, whether he wins victory in open combat or through ruses" (qtd. in Mattox 64).

\section{Discrimination}

Augustine discriminates between soldiers, non-combatants in general, and the clergy. Augustine exonerates the soldier who kills in battle while following the orders of a legitimate authority, since the soldier is obligated to obey the authority, even if the authority itself is unrighteous. The soldier's innocence stems from this obligation to obey. Hence, the taking of the life of an enemy soldier while following orders is justified, but taking lives indiscriminately (for example, the lives of civilians or children who are not instrumental in the war) is never justifiable. Regarding non-combatants, 
(although not providing any rules for identifying them), Augustine advocates mercy "to the vanquished or to the captive" (qtd. in Mattox 63). As for clergy, Augustine has specific expectations of them. Clergy are given permission to flee the city and escape invaders if, first, they were specifically targeted, and second, there was sufficient clergy left behind to look after the spiritual needs of their congregations. In the case of a general emergency however, clergy were supposed to stay and share the danger with everyone else (Mattox 63). He does not advocate a call to arms, but recommends fleeing if possible. It is clear that Augustine condemns any taking up of arms by non-soldiers, even in cases of dire emergency.

\section{Violence towards Religious Dissenters}

While not necessarily falling under the rubric of the just war, Augustine was "the only theologian in the early centuries of Christianity to endorse and to discuss openly the use of coercion for suppressing religious dissent" (Swift qtd. in Mattox 65). These views can shed light on Augustine's general criteria for justification of violence. One such group of religious dissenters was the Donatists, who were problematic for Augustine not merely because of their "heretical" beliefs but also because Donatist clerics committed acts of violence against the orthodox Christian churches. He saw Christian rulers as having an obligation to come to the aid of the Church and its followers: "it concerns Christian kings of this world to wish their mother the Church, of which they have been spiritually born, to have peace in their times" (qtd. in Mattox 67). Augustine's battle cry against the Donatists was "Coge intrare" (compel them to enter) which comes from the Parable of the Feasts in Luke's Gospel (qtd. in Mattox 68). The just cause was to bring 
these wayward sheep back into the fold of orthodoxy, and by this secure their salvation. This kind of thinking, which centuries later would form part of the Crusader justification for inquisition, is now seen as completely removed from modern just war thinking. However, this stream of Augustinian thought serves to emphasise that for Augustine, all action is ultimately to be viewed through the lens of the Christian orthodoxy that he believed in. Unlike the Crusades though, Augustine only advocates the use of force towards heretics and not non-Christians in general. The foundation for his thoughts is ultimately the Christian dogma that underlay his faith. As God himself compelled people to enter into the faith (as he did with Paul on the road to Damascus), so the kings and princes of the earth to whom God has given authority may also find it necessary to compel the heretic (qtd. in Mattox 71). Once again, Augustine uses paternal imagery to bring his point home:

For no one lives against his will; and yet a boy, in order to learn this lesson of his own free will, is beaten contrary to his inclination, and that often by the very man that is most dear to him. And this, indeed, is what the kings would desire to say to you if they were to strike you, for to this end their power has been ordained of God. (qtd. in Mattox 71)

\section{Christianity and the Law: Christian Influences on the Law}

In Roman law, codes of conduct for soldiers (for example those developed by Italian jurists Azo (1190-1220) and his student Accursius (c.1182-1263)) were formulated, which delineated the rights and obligations of soldiers. Roman law limited the authority to wage war to the Emperor alone. Feudal lords, counts, kings or other rulers fell out of the scope of the just war, perhaps because these were viewed as private violence, and not in defence of Empire or Church (Russell, The Just War 46). However, 
Odofredus (d. 1265), when inquiring whether a vassal could aid his lord against his own patria, by reference to canon law, concluded that loyalty to one's patria overrode the fidelity owed to one's lord, and subsequently, wars waged for the defence of the patria came under the purview of the just war (though, patria was never defined as a specific political unit). It is worth noting that for a war to be recognised as such in Roman law, the opponents had to be specifically considered enemies, and the violence or unjustness of their act was less of an issue. Furthermore, a formal of declaration war was required, which could only be made by the emperor against the enemies of the Empire. However, Accursius may have expanded the definition of who a just enemy was, and who could declare the war by introducing Christian ideas of the role of the emperor. Now, a formal declaration of war was also possible by Rome against her rebellious subjects, not just her enemies "probably as a veiled reference to the wars waged between Christian princes within Europe, especially within the empire" (Russell, The Just War 50) which further extended just war conditions to other disputes which were not before recognised as war. Civil lawyers in the late thirteenth century appropriated the just war as "a tool of statecraft in the arsenal of kingdoms that, de jure or de facto, operated outside the jurisdiction of the Holy (Roman) Empire" (Russell, The Just War 50). ${ }^{20}$

Perhaps one of the most important documents of canon law in the Middle Ages was Gratian's Concordia Discordantium Canonum, often called the Decretum. This had a great impact on European canon lawyers and theologians alike. In Distinctio I, Gratian states that the repulsion of violence by violence was justified by natural law. In Causa 23 , in which he deals with warfare, he draws heavily on the writings of Augustine. In his

\footnotetext{
${ }^{20}$ For further distinctions on the legal terms hostes and guerra in Roman law, see Russell, The Just War 49.
} 
interpretations of scripture, he determined that military service appeared to be sinful (citing Matthew 5:39,41; Romans 12:19; Matthew 26:52; Deuteronomy 32:35; Matthew 7:1; Matthew 13:30; Romans 14:4) and he agreed with Origen that Christians were not to emulate the wars of the Old Testament, since they were an allegory of the spiritual wars Christians fight against the devil. However, using Augustine, he ultimately affirms that not all military service was sinful, if done to punish evil-doers (which included defending justice and fighting against the pagans). Punishing evil-doers is, rather, an act of benevolence, performed in their best interest, although against their will. Therefore, wars had to be waged with a benevolent disposition. He then cites Luke 3:14 in which John the Baptist tells Roman soldiers to be content with their wages, rather than asking that they lay down their arms. He interprets this as merely a prohibition on soldiers from seeking more than their legitimate wages for their services. He stated that the precept to love one's enemies did not go so far as to permit sinning with mercy, and his views on capital punishment indicate that he viewed those who enforced the punishment "not as guilty of cruelty, but as ministers of God and avengers of his wrath" (Russell, The Just War 59).

To be just, a war had to meet Christian standards of morality. Gratian's first canon, inspired from Cicero, defines the just war as one waged by an edict to either recover lost goods, to defend against enemy attack, and to avenge prior injuries. ${ }^{21} \mathrm{He}$ also adds the requirement of justice, which had the effect of endowing the just war with judicial process. As the laws of the city were enforced by city authorities, the procedure of war had to be undertaken by the right authorities, rather than private individuals.

\footnotetext{
${ }^{21}$ Russell cites the original text: "Cum ergo iustum bellum sit, quod ex edicto geritur, vel quod iniuriae ulciscuntur' - A just war is waged by an authoritative edict to avenge injuries (The Just War 64, footnote $30)$.
} 
However, he does not specify what just war causes were or what constituted an injury.

He did not specify which authorities could declare a just war, but he justifies war as a means of defence not only of the patria or commonwealth but of self, of the Church and of associates (Russell, The Just War 62). ${ }^{22}$ If repelling injuries done to one's associates is justified, the right of intervention by a third party might also be justified. From this may stem the rudimentary formulations for a right of third party humanitarian intervention (see Russell, The Just War 66). ${ }^{23}$

From this development, it becomes clearer how the Crusades came to be associated with the just war. For example, Bernard of Clairvaux justifies war in the Holy Lands (a Holy War) because "the Lord of heaven is losing his land" and "the enemy of the Cross has begun to lift his sacrilegious head there" (A.F. Holmes 88). ${ }^{24}$ All the wonders of Christendom had to be fought for, such as the holy relics, for they were the basis of the faith in the medieval period. ${ }^{25}$ However, developments in Christian thinking would later come to condemn wars for conversion or in the name of Christ.

\footnotetext{
${ }^{22}$ Russell does note that the word socii, translated as 'associates' did not refer to non-arm's length third party relations, such as allies subject to another prince, but it referred to persons over whom the defender already had some jurisdiction (The Just War 66).

${ }^{23}$ As C. S. Lewis says regarding Jesus' command to turn the other cheek, "Does anyone suppose that our Lord's hearers understood him to mean that if a homicidal maniac, attempting to murder a third party, tried to knock me out of the way, I must stand aside and let him get his victim?" (49-50).

${ }^{24}$ Interestingly, Bernard says that the Jews are not to be persecuted, killed or even put to fight, because they are "the living words of the Scripture, for they remind us always of what our Lord suffered. They are dispersed all over the world so that by expiating their crime [of crucifying the Messiah] they may be everywhere the living witnesses of our redemption" (Holmes 90). It seems as though Jews are only to be preserved for their eventual conversion, since they were God's chosen people (Holmes 91).

${ }^{25}$ Note that in many cases, part of the arguments for wars such as the Crusades were based on notions of Christian theology, namely the belief in the divinity of Christ. The acquisition of relics and protection of the holy lands were justified by linking them directly to God himself, since Christ, as God, lived on the earth as a man.
} 


\section{Thomas Aquinas: Creating a Manual of Christian Theology}

St. Thomas Aquinas (1225-1274) unites natural law tradition with biblical ethics. In his most important work, the Summa Theologice, he sets out both in bello and ad bellum criteria grounded in Christian ethics, although this work was intended as a handbooks for clerics, who are forbidden from participation in war. Nonetheless, these clerics were supposed to embody practices that witness to the governing authorities. Like Augustine, Aquinas also focuses on virtue and the common good in his pronouncements of just war, which is perhaps the reason that he does not elaborate on the in bello criteria to the extent that he does with the ad bellum criteria. As with Ambrose, Aquinas sees the Church as the advisory body to the government regarding the use of force, hence, he sets out guidelines by which clerics were to gauge state action. The motivation for the use of force, as with Augustine, is love (caritas). He reasons that if charity is the virtue necessary for acquiring all other virtues, and therefore, for acquiring excellence in any action war and charity are compatible if war-making is a work of love. When we love a fitting object, the object perfects and improves us. When we love God, which is the highest good and the most rational thing for us to do since the supreme happiness and final goal for all our passions is God, our passions are properly ordered.

St. Thomas explains how the four cardinal virtues in the Christian tradition, prudence, justice, temperance and courage, (which are developed from Platonic virtues by Ambrose and Augustine), relate to the decision to enter war. When it comes to just war theory, charity is the most important virtue, not justice. Charity gives the Christian soldier the impetus to participate in war. St. Thomas classifies each of the four cardinal virtues in terms of its formal principle (what each one is moved by) and in terms of the 
subject matter with which it deals (Summa Theologice (ST) I-II 61.2). Prudence is the exercise of reason, and its subject matter is how reason should operate in practice. Prudence is essential in the decision to go to war and in developing battle strategies. Justice is the employment of reason in human action and its subject matter is how the will is directed towards good acts. It is the virtue that grants the person "the perpetual and constant will to render each one his due" (ST II-II 58.1). Justice is the measuring stick to which we apply prudence in determining the justice of a proposed battle plan. Courage is the proper steering of the passions that drive us to act irrationally in the face of danger or hardship (ST II-II 123.1), and its subject matter is the irascible appetite, which can make us act unreasonably (ST I-II 61.2). It enables leaders to make appropriate decisions for or against war in accordance with prudence. Courage enables soldiers to stand their ground in a battle rather than run away. Temperance is the restraint of the passions when they are contrary to reason, and its subject matter is the concupiscible appetite which provides the passions with their force (ST II-II 141.1). Temperance enables leaders to recognise if any of their motivations for action in a war are based on hate or revenge. It plays an important part in combat behaviour (see Webster and Cole 136-7).

The moral problems of war are approached through the virtues and the common good. War is not a vice, nor is it necessarily opposed to charity but just wars are meritorious acts of charity (ST II-II 29.4, 40.2, 34-43). Neither is peace a virtue, but it is a tranquillity of order that all things desire. Christians have a moral obligation to do what they can to put an end to unjust violence, even through the use of force. This idea of conceiving of fighting a war as a meritorious act of charity has, however, been disputed by modern Christian theorists who argue for a presumption against all acts of violence. 
For St. Thomas, the just wars carried out by Old Testament heroes were virtuous recourse sought out of love of justice (ST I-II 107.2 and 108.3). Commenting on Romans 13, he said that it was not only allowable but "meritorious for Princes to exercise vindication of justice with zeal against bad people" (Commentary on Romans 13, lect. I). He also argues that is "praiseworthy and advantageous" for someone with the proper authority to kill someone dangerous and infectious to the community (ST II-II 64.2). Because motivation is so important, Aquinas recognises that in some cases, killing in self-defence may be permissible, because, the main intention in self-defence is intending to save your own life; the slaying of the aggressor is an unfortunate result (see ST II-II 64.7; also 40.1).

The requirement is that one intends to promote good and avoid evil; there is an element of inner purity in one's conduct as a just warrior (Elshtain 201). Therefore, having identified war as an obligation to end unjust violence, the jus ad bellum criteria exist because any war will cause unintentional suffering owing to collateral damage. In addition, fallen humans can never be certain of their intentions, and in desperate situations, one can never be certain of not committing unjust acts. The justice of the cause has to first be fully investigated because of the unintentional suffering caused by war (Webster and Cole 141-42).

For St. Thomas, the three main rules that define a just war are proper authority, just cause, and right intention (ST II-II 40.1). Right conduct depends upon the virtues of soldiers and commanders. Establishing rules is one way of defining and encouraging right conduct. For St. Thomas, these rules come from secular traditions: the chivalric code and the jus gentium which was influenced by canon law (Webster and Cole 143). Webster and Cole point out that these rules of right conduct are largely culture-dependent 
and whether an action is praiseworthy or blameworthy will vary from place to place (see ST I-II 94.4). For this reason perhaps, Thomas does not list detailed jus in bello rules; it is difficult to list how one should fight in a war because of the many uncertainties that exist in combat situations. Many of these are defined more by local custom. Further, these rules are only second in importance if a just war is to be governed by virtue. Jus in bello requirements of proportion and non-combatant immunity are always binding, but it is difficult to determine what counts as meeting these requirements as this will vary with the individual soldier as well as time and place. However, some jus ad bello criteria will overlap with jus in bello considerations. For example, the requirements of just cause and rightful intention overlap with rules of non-combatant immunity. Rules which define a just war are more binding than rules of combat (Webster and Cole 144-45).

Thomas teaches that war should only be declared for a "just cause" although first, an offer of peace should be made. (A.F. Holmes 104). He reasons that all wars are unlawful, that war is always sinful, but war is not a sin in itself because John the Baptist said to soldiers "Do violence to no man... and be content with your pay" (Luke 3:14). By telling them to be content with their pay, he did not forbid soldiering (A.F. Holmes 107). In order for a war to be just, three things are necessary: the authority of the sovereign; a just cause (that those who are being attacked deserve this on account of some fault, such as inflicting wrong on the sovereign's subjects, or restoring what has been seized unjustly); and, a rightful intention (so that they intend the advancement of good, or the avoidance of evil) (A.F. Holmes 107-08). Thomas recognises fighting might be required for the common good. Even prelates and clerics can fight (as shepherds guarding the flock against wolves) (A.F. Holmes 109). However, for Thomas, one of the 
most important criteria for a just war was that it be legitimately authorised. Since war is a public matter, he says that "those who hold supreme authority" are the only legitimate authority. Of course, the nature of the authority may change, depending on the nature of political organisation, but Thomas allows for those changes, and an interpretation in which the UN Security Council is the only international body through which states or others can legitimately engage in war becomes possible. ${ }^{26}$ And perhaps it is owing to Thomas' legacy that the same safeguards regarding who can legitimately declare war were established by UN legal documents. However, Thomas did not have to tackle questions of veto power or who has the power to vote or the red tape that is associated with eliciting Security Council action; the process itself might jeopardise human lives by delaying necessary military action. Yet, Thomas' criteria directly influence the framework of later just war developments, and also form the basis of the sections in the Catechism of the Catholic Church (1997) that deal with war.

\section{The Crusades}

Perhaps no discussion on just war can be complete without discussing the Crusades. Although holy wars and wars of religion no longer form part of the Christian just war doctrine, must of the language used by the Church during the time of the

\footnotetext{
${ }^{26}$ The Responsibility to Protect specifies that the Security Council ought to remain the only legitimate body to authorise humanitarian intervention. This may avoid accusations of bias, ulterior motives or illegality that occur when regional powers like NATO intervene unilaterally. However, relying on the Security Council is not without its problems for it can act as a hindrance to taking swift action to end humanitarian atrocities. For example, the 1999 NATO-led intervention in Kosovo intervention showed how "[r]elying for legal authority upon the Security Council, which includes Russia and China, two notorious human rights abusers, almost guarantees inaction, even where the human stakes are colossal" (Power). Russia, China and India were the strongest opponents of the NATO action. They view unilateral humanitarian intervention as a representation of the West's imposition of a new "standard of civilisation" that will be used to justify intervention by strong states against weaker ones using humanitarian concerns as a pretext for their own interests.
} 
Crusades made it clear that it was a war that God himself willed. The crusading mentality perhaps arises from the many Old Testament stories where the Israelites, as God's chosen people, conquer various tribes and nations that stand in the way of them fulfilling a covenant between them and their God. Christians inherited much of this sentiment of being "chosen" and their hostility to those "not chosen" came to a climax in the Crusades, which they justified in the name of God. When the First Crusade was called for in 1095, Pope Urban referred to the Turks as an accursed race and he called for Christians to "exterminate this vile race from our lands" (Armstrong 3). Crusaders believed that their fight would have divine support, and that their fighting would yield eternal reward after death. In the Second Crusade, Bernard of Clairvaux claimed that a soldier in the Crusades would be rewarded "with pardon for [their] sins and everlasting glory" (A.F. Holmes 89).

One of the moral problems caused by the Crusades was trying to account for the death of all the innocent civilians who were slaughtered as enemies and infidels. Should innocent civilians ever be killed? Aquinas, like Augustine, looks to the Old Testament story of Abraham and Isaac citing that even God does sanction the killing of innocents. ${ }^{27}$ Francisco de Vitoria (1480-1546) cited Joshua's indiscriminate killing of enemies, including children, as a scriptural example of permitted collateral damage. Although Vitoria ultimately condemns the killing of innocent children stating, "Even with the Turks it is not allowable to kill children" (Maw, Rovie and Viner 41).

\footnotetext{
${ }^{27}$ Isaac was innocent, but Abraham was willing to kill him to show his obedience to the divine will; likewise, just soldiers must sometimes kill innocent civilians, as it is part of the divine plan. It must be noted that killing, for Aquinas, still had to be for the common good, and killing the innocent would not be for the common good (Fiala 37).
} 


\section{The Early Modern Period}

Until the beginning of the sixteenth century, the medieval characterisation of war continued to be influential; however, with the Peace of Westphalia, and the creation of the state system, many of the features of war in the Middle Ages ceased to exist. Christian authority was now questioned, with the advent of Martin Luther and the Reformation. Europeans had also begun to explore and colonise the world, and lawyers and philosophers were stimulated to develop a just war theory that relied on natural law rather than Christian morality so that the people they conquered could be held accountable (Kelsay and Johnson 17). Professional armies, which had long histories and codes of chivalry that formed the code of ethics relating to war, were now replaced by armies of common men. In addition, advances in weaponry made it possible to inflict terrible destruction on less militarily advanced foes. Naval warfare had developed, with overseas lands to conquer. All this required the establishment of codes of conduct. Christian legalists like Vitoria and Grotius would attempt to respond to this need (J.T. Johnson 172, 179-85).

\section{The Protestant Reformation and Just war Theory}

Despite differences in theology with the Roman Church, Luther (1483-1546) and Calvin (1509-1564) both continued the vein of thinking on just war that Ambrose and Augustine began. Luther argues that the civil law and the sword are in the world because of the will of God, and that it is God's will that the sword be used to punish the wicked and protect the just. It is not for the righteous (read: true Christians) that the law exists, because they already do what the law demands of them out of their own free will. 
However, the unrighteous, who are the majority of humans, need the law and the sword to compel them to act righteously, and earthly government is that institution that God provides for this purpose. ${ }^{28}$ According to Luther, Christians ought to involve themselves in government because true Christians live and labour on earth for their neighbours (including non-Christians) and not for their own benefit. In wielding the law and the sword, Christians are performing a service to God, since political institutions have been ordained by God, and it follows from this that war has also been ordained by God (Webster and Cole 152).

To the objection that Christ did not use a sword, Luther argued that Christ's words are meant only to apply to true Christians, and therefore, should only guide relationships between true Christians. Conduct towards non-Christians is an entirely different matter. His other argument against outlawing soldiering is that there were many things that Christ did not do, such as marry, or become a tailor, but this is not to be viewed as a prohibition of others doing so. It is not the occupation of soldiering that is bad, but it is when the office is abused. Like his predecessors, Luther characterises soldiering as an act of love. He notes that although the New Testament does not contain the stories of war commanded by God as in the Old Testament, there is no refutation of the idea of war either, and in fact, John the Baptist, Peter and Paul seem to refute the fact that the institution of war was only meant to apply before Jesus' time. Luther also agrees with Aquinas that it is hard to gauge when the sword is being used properly, but in general, the law must yield to justice. He seems to disallow revolution, stating that only fights between equals are allowed (i.e. between two rulers), and between overlords and

\footnotetext{
${ }^{28}$ See Luther, "Secular Authority: To What Extent It Should Be Obeyed."
} 
subjects (to maintain peace) but not subjects against overlord. Subjects ought to suffer wrong before rebelling, however, rebellion often does no good in the long run because of the destruction involved. Anyone who starts a war is also wrong, since God instituted the sword to maintain peace not start wars. One must wait until it is necessary, and until the thought of war is distasteful before entering into a war. Self-defence is a proper reason for war and is a war of necessity (Webster and Cole 153-154).

Similar to Luther, Calvin argues for a continuity of thought regarding war from the Old Testament to the New. Paul's letter to the Romans provides Calvin with an understanding that God sees to it that people are killed justly, including through the institution of war, because of human disobedience. It is part of God's character to use force against evil, and to use human beings, including Christians, to counter the evil actions of other human beings. For Calvin, the Sermon on the Mount is not a novel code of perfection that abrogates the old law, but it is consistent with the Ten Commandments. The main lessons of the Sermon on the Mount are that personal vengeance is never a motivation that pleases God, and that charity and justice are synonymous. For Calvin, "the reason for waging war which existed in ancient time is equally valid in the present age" (A.F. Holmes 168). For Calvin, the injunction in Romans 13 to pay taxes and respect governing authorities is a moral duty of a Christian because he views governing powers as being instituted by God. However, because these powers have been instituted by God, they also have limits imposed on them by God "to provide for the tranquility of the good and restrain the waywardness of the wicked" (qtd. in Webster and Cole 158). Therefore, those in power who seek to cross these limits or abuse their authority will have to answer to God. The state is viewed as God's servant, therefore, magistrates do not rule 
for their own interests, but for the public good. "In short, he wishes to emphasize that the innocent are protected only through the divine goodness instantiated in the governing authorities" (Webster and Cole 157). For Calvin, Paul paints a picture of the soldier as the state's agent of God's wrath and also of God's love. "So the soldier who does his duty well is modeling his behavior on God's actions revealed in Scripture: he is as much an agent of love and wrath together, for the two characteristics are harmonious in God" (qtd. in Webster and Cole 158). When just warriors fight in a just war, they fight in order to execute God's wrath, which is in harmony with His love. Christians are supposed to bear injustice for the sake of peace, however, they ought to do so "in such a way, that we may be prepared, whenever necessity requires, to fight courageously: for it is impossible that soldiers of Christ should have perpetual peace with the world, whose prince is Satan" (qtd. in Webster and Cole 159).

For Calvin, the purest form of the moral law can be found in the Decalogue. The commandment "Thou shalt not kill" may therefore be expanded to include a positive obligation to preserve the lives of our neighbours, thus making the way for the idea of humanitarian intervention:

We are accordingly commanded, if we find anything of use to us in saving our neighbors' lives, faithfully employ it; if there is anything that makes for their peace, to see to it; if anything harmful, to ward it off; if they are in danger, to lend a helping hand. Scripture notes that this commandment rests upon a twofold basis: man is both the image of God, and our flesh. Now, if we do not wish to violate the image of God, we ought to hold our neighbor sacred. And if we do not wish to renounce all humanity, we ought to cherish his as our own flesh. (qtd. in Webster and Cole 160)

Failing to use force to protect others is, therefore, doing harm to the image of God and Calvin argues that "he who has merely refrained from shedding blood has not therefore 
avoided the crime of murder" and "unless you endeavor to look out for his safety according to your ability and opportunity, you are violating the law with a like heinousness (qtd. in Webster and Cole 161). Calvin goes so far as to say that rejecting the use of force is rejecting God himself: "A Christian man [under the] order of the country, be called to serve his prince, doth not offend God in going to the wars, but is in a holy vocation, which cannot be reproved without blaspheming of God" (qtd. in Webster and Cole 163). He still notes that wars should not be entered into with disordered passion as force cannot be used virtuously if ruled by a disordered passion. Therefore, he advises that princes should only go to war because of necessity and regard for the public good (Webster and Cole 163). The Fall makes man love himself more than loving God or each other, therefore, force is necessary for achieving peace and justice in human society. Civil government is the external means through which human beings are given the

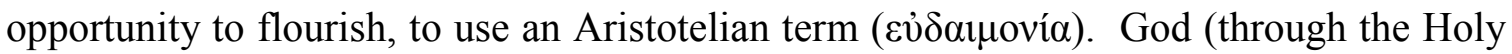
Spirit) provides the internal means for this transformation. Because civil governments use force to protect order and promote good, it allows humans to exist in communities (Webster and Cole 161-3). ${ }^{29}$

Protestant reformers like Luther and Calvin condone the vocation of the soldier. Luther cites the New Testament (Romans 13:1-4; 1 Peter 2:13-14) to describe war as a sword "instituted by God to punish the evil, protect the good, and preserve the peace" (qtd in. Charles 50). This view is a result of his Two Kingdoms theory: the sacred and the secular, each with their own authorities, or in more modern parlance, separation of Church and state. Like Augustine and Aquinas, Luther also characterised a just war as an

\footnotetext{
${ }^{29}$ For example, in our own time, for pacifist communities (e.g. the Amish and Mennonites in North America), their existence as a community is only possible because they are protected by the American or Canadian governments who will use force against those who seek to harm these communities.
} 
act of charity, and argues that it is an act of Christian love to defend and protect a community by the sword. Luther analogises war and soldiering to the acts of a good doctor who may be required to amputate a limb to stave off disease from the rest of the body. For Luther, it is "both Christian and an act of love to kill the enemy without hesitation... until he is conquered... And when victory has been achieved, one should offer mercy and peace to those who surrender and humble themselves" (qtd. in Charles 51). Just wars are necessary in a world of injustice and unjust peace, and soldiers are as "useful to the world as eating or drinking or any other work" (qtd. in Charles 51). In fact, military service was considered a duty of the Christian to bring about peace and justice, and such service is a work of love done for the sake of others. Not serving as a soldier would consequently be acting contrary to love thereby setting a bad example to others. Luther even advocated coming to the aid of third parties, or neighbours ${ }^{30}$ as he says "although you do not need to have your enemy punished, your afflicted neighbour does" and war could be an integral part of Christian discipleship so long as it is not for "avenging yourself or returning evil for evil, but for the good of your neighbour and for the maintenance of the safety and peace of others" (qtd. in Charles 52). Only abuse of the office of the soldier was condemned. However, Luther was no crusader, and he did not advocate inciting war in the name of Christ.

Like Luther, Calvin finds a scriptural basis for the need for war as an instrument of God, and of the magistrate as acting as the agent of God, when he is acting not out of his own accord, but according to the precepts of the Christian faith. In Institutes of the Christian Religion, he states that kings and nations too "have been entrusted with power

\footnotetext{
${ }^{30}$ Note that in the Gospels, when Jesus describes the "neighbour" whom he asks us to love, he says that everyone is one's neighbour (Luke 10:29) - thus making all of humanity neighbours. Moreover, the Christian is asked to love unconditionally and with disinterest ( $\dot{\alpha} \gamma \alpha \dot{\alpha} \pi \eta)$.
} 
to preserve the tranquility of their own territories, to suppress the seditious tumults of disturbers, to succour the victims of oppression, and to punish crimes" (qtd. in Charles 53). He saw it as part of "the nature of the office, therefore, that princes are armed, not only to restrain the crimes of private individuals by judicial punishments, but also to defend the territories committed to their charge by going to war against any hostile aggression" (qtd. in Charles 53). In response to the New Testament objections against war, he responds that the causes of war which existed in the ancient (Old Testament) world still exist, therefore, government authorities retain their primary function of preserving the peace. Finally, he argues that the New Testament did not contain any explicit teaching on war because it was mainly a book on salvation, not on the justification and organisation of civil government. He also cites John the Baptist's encounter with the soldiers as tacit approval for war in the New Testament. He did acknowledge however, that in addition to a just cause, right intent and last resort are moral imperatives: "the evident object of war ought to be the restoration of peace, and certainly we ought to make every other attempt before we have recourse to the decision of arms" (qtd. in Charles 53).

\section{Just War and Natural Law: The Salamanca School}

As stated earlier, during the Middle Ages many legal scholars adapted just war principles by appealing to principles of natural law. As Charles explains

Justice has a deeper basis than mere religious confession. It is known through nature and intuited universally as binding on all people everywhere. Thus the law of nature becomes a law to the nations (ius gentium), holding them accountable to the unchanging demands of justice. Just war principles then find confirmation in natural law and are not a mere appeal to religion. (56) 
Consequently, whereas before the Middle Ages, the emphasis of theorists was primarily on Christian doctrine and secondarily from natural law, during the Renaissance, the natural law basis for the doctrine came to be of primary importance. The application of the doctrine came to be questioned in the face of a divided Christendom, and increasing contact with the non-Christian New World.

Vitoria, after hearing reports of the Spanish treatment of Native Americans in the New World, argues for equal rights of Spanish and Indians regardless of religious background, and argues that Indians had property rights that the Spanish king could not just seize. Therefore, war with the Native Americans to acquire their land was unjust. However, as with previous thinkers, he says that war may be warranted if it is in defence of aggression, for the recovery of stolen property or as punishment for wrongdoing, and he affirms in bello requirements of proportionality and that war be waged only against the guilty party (Charles 56-58). He also acknowledges that only a proper authority can use coercive force, stresses that proper authority lies with government officials who must have recourse against enemies, through the institution of war, in order to "adequately protect the public weal" (Charles 60). In Vitoria's writings, we see the emergence of an "international law" with its moral basis in natural moral law. And perhaps in his questioning of the role of war, and by exempting from fighting those convinced of the injustice of a particular war, he made room for selective conscientious objection (A.F. Holmes 118). Vitoria denied that both sides of a conflict could be just saying, "if the right and justice of each side be certain, it is unlawful to fight against it, either in offence or defence" (qtd. in A.F. Holmes 118). He does however excuse soldiers who are obeying unjust princes in carrying out a war saying that these soldiers may not know that 
their war is unjust and therefore "both sides may be doing what is lawful when they fight" (R.L. Holmes 201). With Vitoria, however, the most important development was that holy wars and Crusades were denounced as being unjust, even though his objections were often ignored by conquistadors (Fiala 37). He stated that difference of religion is not a cause of just war (see May, Rovie and Viner 39) and that "the single and only just cause for commencing a war" is a "wrong received" (qtd. in Fiala 37). Although, Vitoria also believed that the principles of just war really only applied to Christians, therefore, the potential for crusades was perhaps never really extinguished. He states: "There are times when security can not be got save by destroying all one's enemies: and this is especially the case against unbelievers, from whom it is useless to hope for a just peace on any terms" (qtd. in Fiala 37).

Natural law, however, in the context of warfare, could be viewed as anything but natural. Natural seems to imply that these concepts took root organically in various cultures and in various periods of time. However, from the time of Aquinas, natural law itself has been Christianised. Augustine viewed natural law as part of God's plan for the perfection of man. It relies on an understanding of "a metaphysical or theological framework concerning the nature of man and his relationship to the cosmos" (see R.L. Holmes 204).

Francisco Suárez (1548-1617), like Augustine and Aquinas, viewed war as a duty of love. In his most important work, The Three Theological Virtues, he stressed that the laws of war are binding on all nations, enlarging Aquinas' concept of the law of nations (jus gentium) - the often unwritten body of general laws, which has gained acceptance in the course of history - because it serves the well-being of all men and because it 
conforms to the universal and primary principles of natural law, which are unchanging (A.F. Holmes 195, see also Charles 61). He argues for a "required mode of uniformity" as to warfare which must be observed at the beginning of a war, during it and after it since these rules were "founded upon natural law, [and are] common to Christians and unbelievers" (Charles 62). He argues that war is not intrinsically evil, and that Christians are not forbidden to fight. His interpretation of biblical passages is interesting and often contradictory to that of previous thinkers. For example, he says that Christ's command to Peter in the garden is not an interdiction against war but an interdiction against private initiative to use the sword against the wishes of the prince (A.F. Holmes 200). Greater evils may occur if war were never allowed. He states that defensive war is not only permitted but commanded (A.F. Holmes 200) because these are often to repel evil. Defence may also be undertaken under one's own authority (A.F. Holmes 202). In order to wage a just war, in addition to Aquinas' stipulations of a legitimate power, a just cause and just reason, Suárez added proportionality, last resort, and reasonable chance of success (Charles 62). Regarding what is a just cause, he lists the following: a state guarding itself from molestation; and, the enemy to be targeted must have committed some wrong that is deserving of punishment e.g. seizure of property, for reparation, or as punishment (A.F. Holmes 206-07). War against infidels or wars of colonisation and conquest are argued against (A.F. Holmes 212-13). 


\section{Hugo Grotius: Bridging Religious Ideas and State Law}

Hugo Grotius (1583-1645), called the father of international law, was a theologically-trained Dutch Calvinist who used the Roman law of Justinian's Corpus Iuris Civilis which was informed by Greek and Latin writers, and the Bible and its interpretation by Greek and Latin Church Fathers to develop his laws of warfare. He continued the Ambrosian tradition that views war as a human enterprise subject to the limitations of human decision. Incorporating much of the writings of Augustine and Ambrose, he advocated the applicability of universal, natural laws, and he clearly articulated rules that specify both ad bellum and in bello requirements. In Law of War and Peace, for a war to be just, Grotius specified six criteria: just cause, sovereign authority, formal declaration, proportionality, reasonable chance of success, and last resort. Grotius also advocated the use of pre-emptive force in some cases, for example, to ensure the commercial right of passage, to punish treaty violations, to assist an ally in a just cause, or to defend oppressed Christians (Charles 64-65).

Grotius' motivations for expounding a more comprehensive theory of the just war may have stemmed from the readiness of Christian princes in Europe to readily engage in war. Grotius characterised many of these wars as un-Christian and his writing reflects an attempt to correct this behaviour and bring it more in line with Christian notions of justice. Seventeenth century Europe, following the emergence of states became increasingly militarised causing Grotius to remark:

Throughout the Christian world I observed a lack of restraint in relation to war, such as even barbarous races should be ashamed of; I observed that men rush to arms for slight causes, or no cause at all, and that when arms have once been taken up, there is no longer any respect for law, divine or human; it is as if, in accordance with a general degree, frenzy had openly been let loose for the committing of all crimes. (qtd. in R.L. Holmes 229) 
Grotius located Christian limitations on force in the virtue of charity, thus, his treatment of jus in bello is that the just warrior should use only the force that is necessary to alleviate the harm. This kind of treatment of the just war is similar to the view of civil police action to maintain peace, and this forms the foundation of Grotius' laws (A.F. Holmes 166). However, he realised that charity is not the purview of all soldiers, because all soldiers are not Christians. And if there is no charity, there will be no justice. Therefore, instead of charity, he focuses on justice derived from concepts of international law that will govern all soldiers. Webster and Cole describe this as "the secular respond[ing] to the theological by striving for charity but finding a kind of justice instead: a justice governed by law. In effect, the secular says that it cannot always be charitable, but the Christian witness forces it to be at least just, and this justice takes the form of a juridical action" (Webster and Cole 168). However, charity (as Aquinas would have seen it), is not absent from his scheme as the limitations of what is just are informed by charity. "Charity, then, forces the secular to respond, and that response is justice qua international law. Christendom, consequently, bequeathed to the West an account of the just war that limited the use of force with charity and law" (Webster and Cole 168). This quote demonstrates that it is the Christian concept of love for neighbour (both for the attacked and the attacker) that turns war into a positive good. This love, combined with ideas of the fallen nature of mankind is what informs the role of Christians in political and military institutions, and this forms the foundation of Grotius' thinking.

The significance of the contributions of these early modern thinkers cannot be overstated, as it drastically shifted the focus of the justification of war away from a religious ethic, grounded in revelation and on scriptural interpretation, to the attempt at a 
more universal conception of morality. As a result, certain moral standards were upheld, and new standards were aspired to which lay the foundation for contemporary international relations. Many of their contributions were to set the standard for the development of the just war theory in international law. The work of Vitoria and Grotius would be subject to increasing philosophical refinements over the centuries. However, for all practical purposes, the same arguments (developed through the religiously informed traditions of the Church) they used to restrain war were used to broaden the acceptable conditions under which it was undertaken. Perhaps consequently, during this time of just war theorising and the ascendancy of just war theory, the most vicious wars in history occurred, and when the theory was in eclipse, the longest periods of relative tranquillity occurred (Elshtain 198).

More people have been killed in modern warfare than ever before possible, as the combination of nationalism and modern weapons of mass destruction fuel wars that are always justified as being fought for the ultimate just cause (Wells 39). And in countries with Christian majorities, leaders reinforce political rhetoric by appealing to religious morality. For example, in his "fireside chats" in the 1930s, U.S. President Roosevelt used Biblical terms referring to the division of countries in a war as the divide between good and evil and justified American involvement in the war with reference to a Christian tradition (see Roosevelt). Similarly, George W. Bush said "there is a higher father that I appeal to" when asked about whether he had ever consulted his father about the invasion of Iraq (qtd. in Sheer). This kind of thinking seems to conflate both the Augustinian justification of war and the modern one: for Augustine, the primary justification of war was the sanction of God and his divine command; for present day just war theorists, the 
primary justification of war is a response to the crime of aggression against the international system of nation-states (Fiala 40). This kind of conflation is one with which Augustine himself would have been uncomfortable.

There are two consequences of the Christian just war tradition. First, warfare is seen as a positive good when pursued by a just warrior. Second, it creates a positive requirement to use force against evil in order to develop positive virtues and make human society better. It also casts Christians who choose not to engage in just wars as lacking all the theological virtues especially charity and as blasphemers. Just war theory views the just warrior as an agent or an instrument of the divine will to stem injustice and punish evildoers. Therefore, rejecting the use of force is seen as rejecting the acts of the Holy Spirit to make Christians more fit for beatitude with God (see Webster and Cole 170). The just war continues to be the dominant view, even amongst modern just war thinkers whose viewpoints will briefly be examined.

\section{Just War: The Contemporary Viewpoint}

While the Catholic Church clearly embraces the notion of just war and has incorporated this teaching in their Catechism of 1997, there have been many influential Protestant thinkers who have also been staunch supporters of the existence of a just war doctrine. One modern thinker, American-born Protestant Reinhold Niebuhr (1872-1971), begins his work Christianity and Power Politics by arguing why the Church is not pacifist. Niebuhr points to the Gospel, calling Christianity not simply a new law, but, the law of love (emphasis added) and he refers to Christian morality as "the final norm of human conduct" (A.F. Holmes 301-02). However, the morality he advocates is not 
pacifist. He argues that pacifists, like Menno Simons, the founder of the Mennonite Church, were trying to achieve a certain perfectionism that was only accomplished by "disavowing the political task and by freeing the individual of all responsibility for social justice" (A.F. Holmes 301-02). Niebuhr asserts the fact that most pacifist Christians do tend to live within a microsociety created by their church leaders; many live in small, rural communities, are staunchly apolitical and often have little need for anything provided by the state as they live in self-sufficient communities, often with no need for even electricity. This kind of pacifism, therefore, he sees as impossible if one wishes to remain within mainstream political society. In fact, he goes so far as to call these pacifists heretics and describes their interpretations of scripture as the fruit of a futile Renaissance faith that was the result of a "Renaissance spirit, which pervaded the whole of modern Protestantism" which in turn assumed that the "highest measure of peace and justice" would be made possible by man "among selfish and sinful men" (A.F. Holmes 303). This again seems to reinforce the Augustinian notions that war is inevitable in a world in which people will always sin. Niebuhr continues this work in support of a Christian just war doctrine, offering the example of preventing the violence of Nazi Germany as a justification of war (A.F. Holmes 312). He cites the sayings of Jesus that he came "not to being peace but a sword" or that he asked the disciples to sell a cloak and buy a sword. And while he recognises the commands to "love your enemies" and "be ye perfect as your father in heaven is perfect", he downplays their importance stating that these are finally and ultimately normative but "not immediately applicable to securing justice in a sinful world" (A.F. Holmes 305). 
Another important Protestant writer and just war proponent is Paul Ramsey (1913-1988). Ramsey's interpretation of disinterested love, or the concept of agape ( $\dot{\alpha} \gamma \dot{\alpha} \pi \eta)$ creates a preference for just war claims that seems to trump a call for non-violent resistance or pacifism, by creating a "protection paradigm" which authorises force in some conditions to protect the innocent. "Violence can be an expression of love" when one is seeking to protect others (Ramsey 149). However, Ramsey, like Augustine confines use of violence to the level of the state, and proscribes non-resistant pacifism at the individual level (Ramsey 150). Still, Ramsey appears to be very liberal in his approach, even allowing for so-called collateral damage if it is done to serve a greater good of protecting others. Even self-defence is allowed not as "self-defensive selfprotection" but as "neighbour-regarding self-protection" (Ramsey 152). Ramsey places the importance on the intention of the party involved, not the end results. It is not justice that is the concern in social relations except in the context of some pax-ordo or ordo pacis - this is what is to be preserved - order (Ramsey 151-53). Ramsey even justifies using nuclear weapons in a war, that is, he argues against what he terms "nuclear pacifism" (A.F. Holmes 342), though he said that this does not extend to first strike use but only for use as a deterrent to war. This raises the possibility of nuclear deterrence as an expression of Christian love, and this certainly makes me question then whether the politics of nuclear non-proliferation and reduction are actually efficacious in a world that has seemingly wholeheartedly embraced a just war doctrine.

Pacifism is viewed with a certain amount of scorn within mainstream political thinkers. For example, in his influential book, Just and Unjust Wars, Michael Walzer

\footnotetext{
${ }^{31}$ Paul Ramsey, Basic Christian Ethics as quoted in Richard B. Miller, Interpretations of Conflict: Ethics, Pacifism, and the Just war Tradition, University of Chicago Press (1991), 149.
} 
says that non-violent defence "differs from conventional strategies in that it concedes the overrunning of the country that is being defended. It establishes no obstacles capable of stopping a military advance or preventing a military occupation. [...] This is a radical concession, and I don't think that any government has ever made it willingly" (330). As

J. Daryl Charles vehemently argues:

And while pacifism as self-defense is morally legitimate, pacifism as public policy is not. Someone must protect society. Someone must protect the citizenry. Someone must protect the neighborhood. Someone must perform those untidy public services that often are taken for granted. To say that Christians cannot serve in such positions or that political power is inherently evil or that force cannot serve just purposes is simply misguided and lacking support from the Christian Scriptures. Moreover, it is thoroughly out of line with mainstream Christian thinking about vocation throughout the ages, even when it is currently regnant within the academy. (93)

As a result of this kind of anti-pacifist thinking, the newest incarnation of the just

war theory in modern times is the Responsibility to Protect which pierces the shield of state sovereignty affirming the right of states to use violence on other states in order to protect innocent civilians from rogue governments and genocidal conditions.

\section{Modern Just War: Responsibility to Protect}

The endorsement of R2P by the international community represents today's acceptance of just war principles. As the Appendix shows, much of the framework of R2P builds upon the framework suggested by Augustine. Luke Glanville states that "RtoP's emergence can be understood, therefore, as a revival of the idea, deeply rooted in Christian political thought, that there exists not merely a right but an obligation to rescue populations from oppression and mass suffering" (321). Glanville points out how R2P has Christian roots, and that the idea of states having a responsibility to protect civilians 
beyond their borders echoes the teachings of Scripture, the writings of the early Church Fathers, scholastics and natural law theorists (314). In the Old Testament, God asks to rescue those who have been robbed from the hand of their oppressor (Jeremiah 22:3), Isaiah tells people to encourage the oppressed, to defend the cause of the fatherless and of the widow (Isaiah 1:16-17), and the Psalms encourage people to speak up and defend the rights of the poor, the week, the needy, the fatherless and the destitute (Psalms 82:3-4). In the New Testament, commands to do justice are reiterated by Jesus: he said we are to lay down our lives for others and to have pity on those in need (1 John 3:16-17), to feed the hungry, give drink to the thirsty, help the stranger, clothe the naked, tend the sick and visit the imprisoned (Matthew 25:31-46). Although most Biblical verses tend to be about protecting those in your immediate community, or those inside your community of faith, in the Parable of the Good Samaritan (Luke 1:25-37), Jesus indicates that we should assist anyone in need because everyone is our neighbour (Glanville 315-16).

Glanville goes on to explain how throughout the centuries, Christian thinkers from Ambrose to Augustine generally incorporated ideas of saving others in need in their writings on just war. In the sixteenth and seventeenth centuries, the Protestant natural law theorists also wrote about duties to protect civilians in the aftermath of religious persecution. They used both Cicero and Ambrose to defend a duty of forcible intervention (Glanville 317). Grotius too defended a right of war to punish tyranny and to rescue the oppressed, and Emer de Vattel in the mid-eighteenth century built upon this when writing his Law of Nations (Glanville 320). However, Glanville sees all this as being connected to the application of the 'order of charity' or the 'order of love', developed by Christian thinkers from Ambrose onwards, to international relations. 
Originally, the 'order of charity' for a state would have extended only as far as the borders of that state. However, Ambrose and Aquinas insisted that special consideration be given to those in extreme need, even those who are distant from us. This was applied to Spanish relations with political communities in the New World (Glanville 322).

Glanville's article is convincing in showing the connection between Christian just war theory and the development of R2P. An interesting fact to note, however, is that the research documents of R2P themselves point out that R2P had most support amongst the trans-Atlantic community and that amongst developing countries, the predominant view is a scepticism towards humanitarian intervention as merely another rationalisation for unwanted interference by norm-enforcing developed countries ( $R 2 P$ Research 23). The fact that Europe and North America consist largely of Christian communities might also help to account for the geographic distribution for support of R2P.

\section{Dissenting Catholic Viewpoints}

Although the 1997 Catechism supports the just war idea, some within the Catholic Church have recognised that there ought to be alternatives to the ideas of the Augustinian just war within the Roman Catholic church as well, partly as a response to the fact that modern warfare has been far more destructive in the last century than ever before. In their 1983 pastoral letter, The Challenge of Peace, the US Catholic bishops wrote, "While the just war teaching has clearly been in possession for the past 1500 years of Catholic thought, the 'new moment' [the Second Vatican Council] in which we find ourselves sees the just war teaching and nonviolence as distinct but interdependent methods of 
evaluating warfare (120). That is one step forward - recognising the existence of an alternative, although not willing to let go of the just war.

After the first Gulf War when Saddam Hussein invaded Kuwait, however, La Civiltà Cattolica, the Jesuit Italian journal which debates the issues of the day described the just war theory as "outdated", "indefensible and needs to be abandoned" and stated that "modern war is always immoral". In its editorial "Christian Conscience and Modern Warfare" the journal expressed how owing to the devastating effects of modern technology and the massive losses that are incurred in a war, the "theoretical categories and moral judgements which applied to past wars no longer seem applicable to modern warfare". The editors recognised that the criteria for war enumerated in the just war doctrine are untenable in modern warfare. Proportionality could never be met because the harm always exceeded any advantages because of modern weapons. Thus, wars often exacerbate the very problems they are trying to alleviate:

War almost never ends with a true peace: it always leaves behind a remnant of hatred and a thirst for revenge, which will explode as soon as the opportunity offers itself. That is why the human story has been a series of unending wars. War initiates a spiral of hatred and violence, which is extremely difficult to stop. War is therefore useless, since it solves no problems, and damaging because it aggravates problems and makes them insoluble. ("Christian Conscience and Modern Warfare")

The editorial went on to stress that the Church's message should be about emphasising the brotherhood and sisterhood of all people as children of God and that the categories of "stranger" and "enemy" ought to be abandoned. The editors recognised that even noble motives for war can never be ascertained, therefore, total abandonment of war is recommended: 
Being against war and for peace also means opposing the idea that war is "necessary" or "inevitable" and that peace is not possible. Finally, it means opposing the idea that wars are waged for noble motives: to restore a universal order of justice and peace or simply to make amends for injustices. These noble motives - which may be present in a few people in most cases serve as a juridical and moral cover-up for the true motives of war, which are motives of political domination and economic interests. In other words, to oppose the "ideology of war" is to do what is needed to unmask war by showing it as it really is: to uncover its motives and its results. It means to show that it is always the poor and the weak who pay for war, whether they wear a military uniform or belong to the civilian population. ("Christian Conscience and Modern Warfare”)

La Civiltà Cattolica called for Christians to renounce war and to apply nonviolence in national and international conflicts. This seems like a complete reversal of the longstanding Augustinian teachings about the inevitability of war. Whether the Church will officially call for such action seems less likely. Catholic.com for example, which is an American website of "Catholic Answers to Explain and Defend the Faith" says of the just war:

As America turns to God for guidance and strength in the war on terrorism, its actions must be shaped by God's rules for when and how military action may be taken - what Catholic theology calls just war doctrine. It is important that ordinary citizens be informed about these rules so they can help inform our leaders at key junctures through the democratic process. [...] As the Second Vatican Council noted, "insofar as men are sinful, the threat of war hangs over them, and hang over them it will until the return of Christ" (Gaudium et Spes 78). The danger of war will never be completely removed prior to the Second Coming. Christ's followers must be willing to meet this challenge. They must be willing to wage war when it is just and they must be willing to wage it in a just manner. (Just War Doctrine)

Moreover, perhaps the worldview of Catholics (and other denominations) makes it impossible to let go of the 1,500-year legacy of the just war. While the non-just war churches continue to be adamant about supporting only non-violent means to end conflict, the World Council of Churches (comprised of 349 Christian churches and 
denominations) has affirmed and reaffirmed R2P in a number of resolutions since 2003. Pope Benedict XVI mentioned R2P in his address to the General Assembly of the UN on 18 April 2008 and called for its implementation in his encyclical Caritas in Veritate, issued on 29 June 2009 (Winright). And perhaps, this influences the inability of international institutions like the UN to let go of the just war, thus supporting a responsibility to protect.

\section{Conclusion}

In this chapter, I have illustrated the continuity of thought regarding justifications of war from the early Church Fathers to the development of modern legal codes on warfare such as R2P. The importance of the Christian influence cannot be underscored, despite attempts at secularisation and universalisation of the rules of war by distancing them from Biblical precepts, or Church doctrine. While this chapter has concentrated on the development of rules and norms, by examining how the authors of the Bible, and Christian thinkers throughout the ages have interpreted and defined Christian morality, an examination of Christian theology and dogma will demonstrate how these interpretations are also connected with particular kinds of Christianity. As a consequence of these connections, current norms of international relations rely not only on Christian morality but are also intimately linked to Christian theology and metaphysics.

The criteria once developed to limit warfare seem irrelevant to our times, and even some in the Catholic Church, which once only subscribed to the teachings of its great doctor Augustine, are now calling for alternative action. Just causes are harder to identify, as one notices with the war on Iraq following the war in Afghanistan in 2002. 
Right intentions are hard to identify when countries ignore the plight of people in some genocides (e.g. Rwanda, Syria) and intervene with full force where there may have been fewer indications of an imminent genocide (e.g. Kosovo). Just war theory demands that the benefits of a war outweigh the harm caused by the war. In many wars, when the fighting has ended, and the dead and wounded have to be dealt with, it is more difficult to ascertain if less damage was caused. Large numbers of civilian casualties are unavoidable with the tactics and techniques of modern warfare. Moreover, even those "just warriors" of the American military further violated acceptable ideas of justice through torture, abuse and murder of prisoners held in Abu Ghraib and Guantanamo Bay. In reality, there are no perfectly just persons, nor leaders, nor states. Consequently, perhaps as Fiala laments, the just war is just a myth. We must realise that no wars are automatically just, and the nature of warfare in the real world makes it likely that wars will never be just (Fiala 26). Perhaps a re-examination of the doctrine of just war, with reference to the Christian pacifist view, or to non-Christian, non-Western sources of morality may indeed result in vastly different concepts of morality and more nuanced formulations of the just war criteria. But there is a lack of understanding about how Christianity really influences ideas of just war. In the next chapter, I will examine how other aspects of the Christian worldview, which are not directly connected to war, influence the just war doctrine. 


\section{Chapter 2 - The Theological Basis for the Christian Just War}

It is a strange commentary on the West that there - although its creed is Christianity - no Christianity and no Christ exists, otherwise no war would have happened there. (Mahatma Gandhi qtd. in Beier 131)

\section{Introduction}

Having explored how Christian thought gradually developed from an originally pacifist tradition to one in which war was allowed if certain criteria were met, I will now turn to a deeper understanding of the theology behind the texts which led to the philosophy which influenced political thought in the West.

Originally, the exercise of philosophy was one that was seen by some Christians as something that might distract the faithful from the sacred truths revealed in the Gospel. As Paul says in his letter to the Colossians: "See to it that no one takes you captive through philosophy and empty deceit, according to human tradition, according to the elemental spirits of the universe, and not according to Christ" (Colossians 2:8). Nonetheless, many attempted at rapprochement between philosophical thought and Christian theology, and by the time Origen wrote First Principles in the third century, the Christian philosophical tradition became firmly established. At the same time, the Church was defined as a sacred structure analogous to the secular political structure of the state, although in reality, this kind of analogy may be difficult to reconcile with the teachings of Jesus and Paul. Eventually, the centre of European intellectual life was this synthesis of classical philosophy and Christian thought, although, in the last two centuries, philosophy seems to have returned to its ancient role as an intellectual alternative to prophetic religion (Bailie 235-36). 
What always remained constant, however, was that Christian metaphysical assumptions were presupposed by philosophers from Augustine to Grotius and continue to be presupposed by Christians today (see Stead 219). Frederick Christian Bauerschmidt notes how Aquinas' political theology is based not on his appeals to natural law, but in fact is rooted in "his identification of truth with the God of Israel, incarnate in Jesus Christ" (48). He continues:

[...] I am convinced that the nontheological account of natural law that some claim to find in Aquinas is simply not there. While Thomas discusses "natural law" in various places in his writings, one ought not to abstract these discussions from their theological context. Attention to this context yields an account of natural law that is both more theological and more modest than the one often ascribed to Aquinas. (54)

Bauerschmidt notes that out of the 512 questions in the Summa Theologioe, only one is dedicated to natural law, which raises the question of whether the importance of natural law in Aquinas' thought has been overestimated (55). "The autonomy he gives to secular politics through his notion of natural law, is in fact not Thomas' position at all" (58). The ideas of Aquinas and Augustine are clearly rooted in their faith and in scripture (49). When Aquinas discusses the law, it is not natural law but divine reason or the eternal law of God that guides the workings of the universe (see $S T$ 1-2.91.1). For Bauerschmidt, one cannot attempt to reduce Aquinas' discussion of law to natural law because Aquinas' law is not simply theological but Christological: "It begins by rooting all law in the eternal law expressed by the Father in the generation of the Son and ends with the new law of Christ, given through the Spirit to his disciples" (57). As a consequence, in a well-ordered and just society, for Aquinas, society's laws ought to promote the Gospel. Therefore, he argued that unbelievers should not be allowed to establish their rule over believers (ST 2-2.10.10), that heretics were an illness of the body 
politic and could under certain circumstances be killed (ST 2-2.11.3), and that an apostate prince could be deposed of (ST 2-2.12.2). He also espouses the belief in an ordering in the relations between men and women or masters and slaves. Yet, these kinds of arguments would have little credence today, although Aquinas' ideas of the just war continue to resound. Bauerschmidt warns: "Any proposed use of Thomas today must accept the fact that his views are not easily separable from the ecclesial-political situation of his day; and it must equally accept that Thomas' ecclesial-political situation no longer obtains in our day" (58).

It is bearing this in mind that the theology behind the just war doctrine will be explored further. I will examine certain doctrinal stances within the Church (mainly the Catholic Church) and attempt to illustrate how Christian dogma intersects with the Christian political theology of war. I also will explore the works of three contemporary Christian philosophers - French philosopher, anthropologist and literary critic René Girard, German psychologist, theologian and former Catholic priest Eugen Drewermann and American Catholic philosopher Gil Bailie. These men offer differing theories on why or how Christian theology and mythology/history create the psychological atmosphere and provide a justification for the "belligerent tendency of the human spirit" (qtd. in Beier 137). The insight from these thinkers reveals other, perhaps more hidden aspects that make up the foundation of a Christian worldview. 


\section{Christianity Defined}

Before any further analysis, a brief overview of Christianity's main beliefs is worth looking at. Notwithstanding the many doctrinal differences amongst various Christian denominations, Christianity has certain key beliefs that most denominations have in common. Central to the Christianity, as with the other Abrahamic faiths is the belief in one God. Christianity, however, modifies this by introducing the concept of the Trinity - a three-in-one God who is one but made up of three persons, the Father, the Son and the Holy Spirit, all of whom are God. It is God who is viewed as the creator of all things from nothing. Christians further believe that the original man and woman created by God sinned against him, and it is because of this sin that death, evil, destruction, violence, and illness entered the world. However, they believe that God sent his Son, Jesus, down on earth around two millennia ago, and by the sacrifice of Jesus, who was crucified by the Romans, salvation for mankind was obtained. After being crucified, however, Christians believe that Jesus rose from the dead after three days, met with his disciples and then rose to heaven. In order to obtain salvation, many Christians believe that faith in the redemption of Jesus is required. Furthermore, at the end of the world, Jesus will come again to judge the living and the dead, and those who are judged good will live in eternity with God, while those who are judged evil will suffer eternal damnation in a state of Hell, removed from the loving presence of God. 
The main statement of faith for the majority of Christians from the time of the council of Nicaea in $325 \mathrm{CE}$ until today ${ }^{32}$ remains the Nicene Creed (also called the Niceno-Constantinopolitan Creed) by which Christians profess their faith:

We believe in one God, the Father, the Almighty, maker of heaven and earth, of all that is, seen and unseen.

We believe in one Lord, Jesus Christ, the only Son of God, eternally begotten of the Father, God from God, Light from Light, true God from true God, begotten, not made, of one Being with the Father. Through him all things were made. For us and for our salvation he came down from heaven: by the power of the Holy Spirit he became incarnate from the Virgin Mary, and was made man. For our sake he was crucified under Pontius Pilate; he suffered death and was buried. On the third day he rose again in accordance with the Scriptures; he ascended into heaven and is seated at the right hand of the Father. He will come again in glory to judge the living and the dead, and his kingdom will have no end.

We believe in the Holy Spirit, the Lord, the giver of life, who proceeds from the Father (and the Son). With the Father and the Son he is worshiped and glorified. He has spoken through the Prophets. We believe in one holy catholic and apostolic Church. We acknowledge one baptism for the forgiveness of sins. We look for the resurrection of the dead, and the life of the world to come. Amen.

This was a theology with which Augustine would have undoubtedly been very familiar. He would have also been familiar with ideas that would later form the Athanasian Creed, which further expounded on the idea of the Trinity and stressed the Incarnation of Jesus as a critical element of faith, which had to be believed in order for a person to be saved. These beliefs must always be borne in mind when analysing the work of the early Christian philosophers.

\footnotetext{
${ }^{32}$ The modern version reflects the changes that were made in the First Council of Constantinople in 381 CE.
} 


\section{The Beginning: The Extent of the Augustinian Contribution}

Elshtain states that despite the fact that much has been written about Augustine's political theology, what is "political" must be teased out from works which are primarily theological in nature (35). Augustine does not really have any unified theory of just war, and none of his works deal directly or exclusively with this subject. Rather it is from weaving together various fragments from his work that a remarkable unified tapestry of just war theory can be created, in tandem with his view of other state practices related to war (e.g. the use of violence by the state in punishing criminals or in coercing religious practice) (Mattox 5). Although tagged as a political realist (in the vein of Machiavelli and Hobbes), Elshtain argues that doing so is ignoring the theological content. By choosing to focus on certain passages rather than the works as a whole, it is easy to number Augustine "among the pessimists [read: political realists] [...] who stress human cruelty and violence with a concomitant need for order, coercion, punishment, and occasional war" (Elshtain 36). She advises, however, that rather than approaching Augustine narrowly, one should embrace his expansiveness (36).

While certainly not being the first to develop a theory of just war, Augustine has been called the father of the Western just war theory. This is because his theory laid a foundation to subsequent developments in Western thought because Augustine synthesised the Neo-Platonic philosophical tradition of the West with the more immediate concerns of emperors and armies (Mattox 2-3). In other words, it created a framework by which Christians who may have been equivocal or hesitant in the past could now justify military participation, perhaps by trying to make fighting less brutal (see Mattox 3-4). Mattox claims, however, that 
[o]ver the course of the sixteen centuries that have passed since Augustine's day, secular Western society has reorganized itself on the bases of operating assumptions very different from those used by Augustine, Nevertheless, even if most contemporary attempts to elucidate the theory of just war do not obviously rely on Augustine's assumptions, his influence becomes evident as one examines the similarities between Augustine's actual statements on just war and contemporary statements on the same issues. (3)

Mattox notes that when reading Augustine, one must continually bear in mind that Augustine the philosopher and theologian is primarily a rhetorician and polemicist. Therefore, his points are often made in refutation of opposing arguments rather than positive points that support his own original arguments. Another point to bear in mind is that Augustine's writings do not necessarily seek to lay down legal rules and regulations or principles for the law of nations, but instead are intended for the practising Christian who was a soldier in Caesar's army. Mattox does, however, point out that this might appear to be inconsistent to any reader of Augustine's collective just war statements that his views were meant to apply only to individuals (7).

\section{Augustine on War and Peace}

In brief, Augustine's theology is based on the rejection of metaphysical dualism (from Augustine's earlier Manichean influences) and repudiation of the claim that evil is a self-sustaining, generative principle of opposition to good. The rejection of metaphysical dualism characterises creation as good, and the body as good. It is what we do with the body or to creation that mars it. Our actions are contingent upon human free will (which Hannah Arendt identifies as an original Augustinian contribution). We have a choice between evil and good actions, and the very existence of this choice, for Augustine meant that by nature we are good, although we might be prone to making 
wrong choices because we are marked from the beginning with the trace of originary disobedience (Elshtain 44). "Evil is the turning of a limited creature from God to himself and hence, to an absolutizing of his own flawed will. This turning may become habitual, a kind of second nature" (Elshtain 44). War is perhaps the "first and foremost [...] example of human sinfulness" (Elshtain 44) created by the actions of our flawed will, hence, for Augustine, even a just war is always a tragedy. Yet, Augustine justifies war under certain circumstances.

Upon reflecting on all the destructive wars carried out for wicked motives (e.g. Roman empire-building) Augustine reasons that despite lamenting the need for war, limited, justifiable wars may be the only kind that can be waged given the injustices that already exist, hence, a kind of endorsement of a lesser evil. In other words, there may exist real wars of defence without ulterior motives. For Augustine, the only motivation must be neighbour love and a desire for a more authentic peace. Elshtain notes that even these justifiable wars are occasions of great sorrow: "There are no victory parades in Augustine's world; for, however just the cause, war stirs up temptations to ravish and to devour, often in order to ensure peace. Just war, for Augustine, is a cautionary tale, not an incautious and reckless call to arms" (46).

\section{Augustine's ontology and epistemology}

Augustine's intellectual influences were many. First, he studied law in Carthage. He later joined the Manichaean sect, which combined the rational justification of philosophy with the spiritual justification of faith. He then studied literature in Rome, and then obtained a professorship at Milan. There, he attended the sermons of Bishop 
Ambrose and became attracted to Christianity. His readings of Platonist philosophy had made him sceptical of Manichaeism, however, he still admired the Manichaean teaching and its pursuit of philosophy. His readings of the scriptures convinced him that the revelation of scripture complemented Platonic philosophy. His resistance to become a Christian was hampered by his inability to lead a celibate life - which he was convinced was necessary. In his early thirties, he was baptised and a few years later, he was made Bishop of Hippo (Stead 219-20). Throughout his life, however, the Platonic influences remain strong, because it is highly unlikely that Augustine contrasted religion with philosophy, more viewing philosophy as a tool, as an "intellectual substructure" (Stead 223) for grasping concepts of faith. As Platonism mined the works of Plato, so Augustine mined Scripture for the source for his ideas. Faith implied acceptance of certain beliefs; some of these beliefs may be outside rational thought, but the authority of faith is backed up by the divine revelation of Scripture.

His basic assumptions of human knowledge are summarised by two arguments (see Augustine, Contra Academicos 3.10.23, 11.25 and 29). First is the idea that some propositions cannot be false (e.g. some propositions of mathematics and logic). Second is that some propositions can be certainly known. He appeals to the knowledge of one's own mind. This is a Platonic kind of rationalism which argues that relations between concepts can be known by intellectual intuition. Like the Neoplatonists, he recognises that much of our knowledge is based on what we can perceive with our senses, and that sensing was not a function of the body but of the soul by means of the body (Gen. ad Litt. 3.5.7) (Stead 224-5). Augustine thought that the mind could not be affected by the body, which belongs to a lower order of reality. This seems to be contrary to common 
experience, which indicates that intense physical sensations and the passion that accompanies them may often succeed in influencing our judgement. He thought that knowledge was hidden in the depths of the human mind, and that knowledge is a reflection of God's being in the universe (Stead 227-9). This idea of knowledge is what is influential in the way Augustine read scripture, and therefore, how he rationalised ideas about warfare through his understanding of biblical texts.

\section{Augustine's method of exegesis}

Origen advocated allegorical readings of scriptures for passages which seemed to contradict reason. However, as has already briefly been discussed, Augustine uses a literal interpretation for the Fall or for wars of the Old Testament and an allegorical interpretation for the sayings of Jesus (that seem to condemn war) in the New Testament. For example, in his short treatise The Literal Meaning of Genesis he just looks at the plain meaning of historical facts (Smith 20). In terms of how he interpreted scripture, owing to the concept of apostolic succession, he viewed his position as an ordained priest as "confer[ing] upon him whatever divine authorization may be necessary in order to take policy-type positions with regard to new doctrine" (Mattox 139). He did not even consider himself bound to the writings of earlier thinkers, instead stating that it was scripture alone that was infallible and not the words of Church leaders (see Mattox 143).

Thomas Williams warns that Augustine's “approach is not scholarly in the modern sense $[\ldots]$ and the results are often anything but commonsensical (qtd. in Stump and Kretzmann 60). Augustine states that he hears the voice of God in his "inward ear" (Confessions 12.15.18, also 12.11). It is this voice, the voice of truth, which informs him 
in his exegesis (Stump and Kretzmann 63). Augustine realises that scriptural exegesis has certain problems and that we can never determine the author's intentions. However, for Augustine, determining the author's intentions is not the goal of biblical exegesis. This is because we can never be sure of understanding the author's intention because we cannot interrogate the author; therefore, there might be many possible interpretations. This is further confounded by the fact that most of us, including Augustine himself, read the Bible in translation from the original languages. Further, Augustine takes for granted that the text reveals the truth, because it is the product of divine inspiration. Divine truth is available to us even apart from our interpretation of scripture. He even acknowledges that his own interpretation may be incomplete or lacking, only to be revealed by later biblical readers (see Confessions 12.32.43). This does not mean that scripture is unnecessary just because we have independent access to the truth. This is because Augustine views the written words of scripture as signs that help direct the mind to the realities that they signify - realities that we might otherwise miss without the direction of scripture. The aim of textual exegesis for Augustine is charity, and not the pursuit of knowledge for its own sake. This kind of pursuit is a vice, because it is a pursuit of the worldly. The only aim of exegesis should be to cultivate love of God and love of neighbour: "Whoever thinks he has understood the divine scriptures or any part of them in such a way that his understanding does not build up the twin love of God and neighbour has not yet understood them at all" (Augustine, On Christian Doctrine 1.36.40). This kind of exegetic method seems to be that which most Christians perhaps ascribe to today, which tends to result in a lack of tolerance for opposing viewpoints. It is the kind of exegesis that is delivered from the pulpit. This is not the exegesis of the 
modern Biblical scholar who tries to decipher to meaning of every word, from as early original language sources as possible, and bearing in mind historical mores and rules of the time those texts were written, as well as evidence from history and archaeology. In fact, this more careful kind of Biblical studies really only began in the nineteenth century, as more original manuscripts started to be discovered. As academic discoveries start to filter down to clergy, attitudes have now moved significantly away from those of Augustine (as evidenced by the writings of priests such as Drewermann or Spong).

\section{Creation, human nature, politics and Augustine's attitude to war}

The Biblical story of creation naturally leads to certain conclusions about human nature, the idea of sin and finally, the idea of grace and salvation. The Genesis story places human beings at the height of God's creation, and expresses an understanding of humans as being created in the image of God (imago Dei) (cf. Genesis 1:27). According to Genesis, after God created all that exists and after creating all other earthly creatures, He created man (Adam) from clay and woman (Eve) from the rib of Adam to be his helpmate. God gives this primordial couple dominion over everything in the earth and under the earth, in the sky and in the seas. He places them in a fertile garden called Eden and allows them free range of everything in the garden except two trees, the tree of life and the tree of knowledge of good and evil. ${ }^{33}$ However, a serpent tempts Eve to eat of the fruit of the tree because it tells her that she will become like God. Eve gives in, eats of the fruit, and shares it with her husband. Because of this transgression, they are banished from the garden, and as a result, pain, sickness and suffering are said to have

\footnotetext{
${ }^{33}$ Some scholars think that both names refer to only one tree - the tree of the knowledge of good and evil.
} 
entered the world. From that day man is condemned to toil heavily and women to have pain during childbirth. Augustine believed that this first sin, or Original $\mathrm{Sin},{ }^{34}$ becomes an inherited condition for all mankind and the cause of evil in this world is that first sin which now causes man to stray from the will of God - the Fall. This idea continues to form part of Roman Catholic teaching even today, and is perhaps one of the most important factors that contribute to the existence of the Church's just war theory, because war is viewed as a necessary part of living in a fallen state of nature. Because of Original Sin, the basic assumption is that humans are forever and irreversibly tainted by sin because of the actions of our first parents in the Garden of Eden, and this results in a lust for domination. Augustine even refers to humanity as "a mass of sin" inherently at odds with God, and under just condemnation by God (qtd. in Webster and Cole 131). The goal for humanity is to restore the relationship between itself and God, that is, to seek the proper place for humanity in the divine order. This is the sum total of Christian behaviour (Webster and Cole 132).

Every creature is good insofar as it exists because God, who created everything by His will is good, and everything that he creates is good (Conf. 13.2.2-3, CofG 11.21). However, not all creatures are equally good; some are better than others (CofG 11.22). When a creature is characterised as evil, this refers to a privation, an absence of

\footnotetext{
${ }^{34}$ McGrath notes, however, that the idea of the Fall being expressed in terms of the doctrine of Original Sin was not associated with the Greek patristic writers, but is a later development associated with Augustine. The Greek writers taught that sin arose from the abuse of human free will. (The differences between the Greek Orthodox interpretation of the Fall and the Roman Catholic one may explain, in part, why the many Eastern Orthodox churches do not subscribe to any just war theories.) In fact, the idea of original sin was foreign to Gregory of Nazianzus and Gregory of Nyssa who taught that infants are born without sin. St. John Chrysostom interpreted Paul's contention that "for as by one man's disobedience many were made sinners" (Romans 5:19) not in terms of original sin but in terms of liability to punishment and death. There was, however, recognition that all of humanity was involved in the sin of Adam, and that the consequences of sin (being moral wickedness) arise from the disobedience of Adam, which results in a predisposition to sin. This would later form the foundation of Augustine's idea of transmission of original sin to humanity (McGrath 426).
} 
goodness, which derives from the fact that creatures are mutable and have a natural tendency towards corruption (Conf. 3.7.12). Human beings have free will, which is also a good thing that is needed for right living. Sin is the abandonment of better things, not a desire for naturally evil things (Against Faustus 36). It is not just any "less better thing" however, that results in evil, but this thing must be something forbidden to the desirer by justice (De Genesi ad litteram imperfectus liber 1.3). Justice is derived from God's eternal law (De lib. arb. 1.60.50), so that which God forbids is sinful. The sin lies in the individual consenting to (i.e. intending to act on or failing to suppress) the desire to do that which is forbidden (De continentia 2.3-5). Therefore, sin is a direct reflection of a turning away of the human will from God to something inferior. The element of fault attributed to the person arises because it is an exercise of free will by the person. However, with respect to where the desire to abandon these better things comes, Augustine says, that he does not know the answer (De lib. arb. 2.30.54). Similarly, Augustine offers no causal explanation for God's will to create, except that it comes from God's will. William Mann explains that similarly, human will in sinning has no cause, but one of the aspects of the human will is the ability to reject the verdict of reason (46). As Mann explains, "[a] genuinely free will necessarily carries with it the liability to sin. But without having freedom of choice, with its built in liability [to reject reason], humans would lack the capacity to choose to live rightly" (46).

Two case studies for Augustine which demonstrate the wilfulness of sin are Satan's defection from the ranks of the angels, and the sin of disobedience of Adam and Eve in the garden. For Augustine, the motivation for Satan rejecting God was pride (superbia) which he defines as "the love of one's own excellence" (De Gen. ad litt. 
11.14.18) and a "desire for perverse elevation" ( $\operatorname{Cof} G$ 14.13). It is also the initial impulse for the disobedience of Adam and Eve (De Gen. ad litt. 11.5.7; CofG 14.13). The role of the devil was not coercion, for if Adam and Eve were coerced, their punishment would have been unfair. They voluntarily succumbed to temptation because of their prideful desire to become like God. This sin of pride resulted in a sinful condition - the condition of original $\sin$ - which was imposed by God as a punishment for disobedience. This pathological condition that all humans inherit includes "dispossession from a naturally perfect environment, the loss of natural immortality and the acquisition of susceptibility to physical pain, fatigue, disease, aging, and rebellious bodily disorders, especially sexual lust (De Gen. ad litt. 11.32.42; CofG 14.16-19) (Mann 47). The soul is not affected by original $\sin$ in that it still has the ability to reason and to will, however, the physical disabilities as a result of original sin do make it more difficult for the humans to exercise their souls' abilities.

The major source of disorder is pride. As Augustine states: "Pride is the source of all diseases, because pride is the source of all sins" (qtd. in Mattox 103). It is "a longing for a perverse kind of exaltation" (qtd. in Mattox 103). Unjust wars are rooted in pride, and pervert the right order. However, pride is also unavoidable as it is a distinctive characteristic of natural, fallen Man. It is unavoidable since the attempts of man to build the tower of Babel to reach heaven. This was an act of pride, which God punished by confusing language and the separation of man into different groups (see CofG XVI.4). This separation further creates more pride that materialises as enmity between groups of men such that, "a man would be more cheerful with his dog for company than with a foreigner" (qtd. in Balling 104). 
The goal of the earthly city is to hold evil actions in check (Epistle 153.6.16). The state is tasked with minimising disorder and providing a place for citizens to reach the ultimate good, which is God ( $\operatorname{Cof} G 3.10$ and 22.6). This does not mean that the state can do what it likes, but there must be a standard for governing bodies. This standard means using one's power for the service of God. Three basic duties arise in the establishment of peace and order: providing a place for the worship of God; carrying out the task of the judiciary, and; taking vengeance on wrongs (Webster and Cole 132). For Augustine, wars form part of the divine plan for human history. War is inevitable by divine design, and therefore, God must have ordained that man would engage in war (see Mattox 32).

War, therefore, as an act of God, is a manifestation of God's love for mankind, and it works for the good of humanity. It is a means of chastisement and correction, and also to train people to lead a more righteous life. It can even be seen as a reward when the righteous who are killed in wars are removed to a "better state" (Mattox 33). The righteous who are spared are permitted to continue to be instruments of the will of God. The wicked who are chastened through war are receiving their due. For Augustine, a just war is a duty of a righteous state possessed of good will. It is more cruel to withhold the punishment of an erring state by not engaging in a just war than to engage in the war itself: "It does not follow that those who are loved should be cruelly left to yield themselves with impunity to their bad will; but in so far as power is given, they ought to be both prevented from evil and compelled to good. [...] [I]t was not death itself that would injure those who were being punished with death, but sin, which might be increased if they continue to live" (qtd. in Mattox 34). 
Mattox questions why Augustine did not, as the Latin patristic writers had done before, just relegate war as a worldly concern that should not be of any importance to true Christians. His answer is that Augustine's view of humanity lacked the optimism that humans are inclined to understand the real truth and to maintain themselves on the righteous path. Because of the Fall, humanity has a tendency towards evil, and the lust for domination (libido domini) which ultimately leads him to war and violence. Augustine's deliberation with the just war is part and parcel of his deliberation with other social issues, and his pronouncements on war are consistent with his other social pronouncements. A faithful Christian had to be shown to understand and cope with the injustices of war just as much as other aspects of the earthly city. However, Mattox further elaborates that in Augustine's mind, what constituted just wars were the internal police actions within the Roman Empire which were used to quell internal rebellions and restore the peace, or defensive wars to protect the borders of the Empire. Unjust wars were wars of imperialistic expansion. Another scholar even states that it was in response to ideas of Christian pacifism, which many thought had weakened the Empire, that Augustine developed his theory of a just war (cf. Zampaglione 306). When Church and state were united by Constantine, the enemies of the Church became the enemies of the state (Mattox 143). The State acquired a pre-eminent status as the guardian for the Church, and this was reaffirmed by the Council of Arles in 314, which said that forbidding the state the right to go to war was to condemn it to extinction. Condemning the state to extinction would, therefore, in a way also condemn Christianity to extinction. Therefore, if war is inevitable, one at least had to formulate rules to try to reduce the violence (see "Christianity and the Ethics of War"). 
The intention for all wars, however, must be peace and the peacemaker who uses the word is better than the peacemaker who uses the sword (see Epistle 229.2). The just warrior's charity-informed inward disposition is to guide his actions, even if those actions demand violence. It is because of the connection that Augustine makes between war and love that soldiers are absolved of guilt as they are seen to be engaging in an act of love for the other, by putting them on the path of righteousness, and by seeking and attaining retributive justice in the service of the ultimate Christian virtue of love. War itself is not evil. Augustine "never condemns involvement in the world as intrinsically evil" but rather, "concluded that the experience of individuals and societies consisted in the interplay between their ontological goodness and their willful evil" (Russell, "Only Something Good Can Be Evil" 710). In Augustinian terms, to say that war is evil may only serve to highlight the fact that, even for wars specifically ordained by God, because the execution is undertaken by mere mortals who can deviate from the good, war has the potential for evil. But war is not evil per se because if it exists, it partakes of being, and therefore is to some extent good (see Mattox 99). Augustine says:

What is the evil in war? Is it the death of some who will soon die in any case, that others may live in peaceful subjection? This is mere cowardly dislike, not any religious feeling. The real evils in war are love of violence, revengeful cruelty, fierce and implacable enmity, wild resistance, and the lust of power, and such like; and it is generally to punish these things, when force is required to inflict the punishment, that, in obedience to God or some lawful authority, good men undertake wars, when they find themselves in such a position as regards the conduct of human affairs, that right conduct requires them to act, or to make others act in this way. (qtd. in Mattox 97) 


\section{The Failures of Augustine}

In the last few pages, as well as in the first chapter, I have examined Augustine's methodology, his influences and his way of seeing the world, which was completely influenced by his place in history and the outlook on life that his Christian faith gave him. Many aspects of Augustine's worldview are still relevant for many Christians today, but many of them are not. As American Episcopalian Bishop John Shelby Spong argues, (although admittedly, he argues more as an academic than a representative of his denomination) the "theology that developed within the third and fourth centuries of the Christian Era in a Greek-thinking, Greek-speaking, dualistic-thinking Mediterranean world in which the Christian story was historically cast after it had left its Jewish womb and had become a Gentile Church" is not authentic to the Christian experience ("Recasting the Christ"). He lists a variety of ways in which the Christian experience has changed. He explains that Augustine formed his view of reality by reading the Bible literally. But now, we know that the first story of creation in the first chapter of Genesis was really written in the sixth century when the Jews were exiled in Babylon, and it is based on the Babylonian story. The second chapter of Genesis, about Adam and Eve, has

now been shown to be 500 years older than the first chapter. However, if read as a continuous story, the way that evil entered the world is described as the direct consequence of man disobeying God; how else would a world that God sees as good during his act of creation become tainted? Not only sin, but also death was the result of this disobedience. Because $\sin$ is so grievous, the only way that people could save themselves was if God Himself (Jesus) was killed. How does this affect how people view God? As Spong exclaims: 
God becomes a monster, God's an ogre, God is one that does not know how to forgive, God is one who has to have a human sacrifice, a blood offering. It turns our religion into a religion of guilt and manipulation. [...] You and I become guilt-filled people; the primary coin of the realm of Christianity has been guilt. Guilt - the gift that keeps on giving. [...] The message of the Christian church cannot be just guilt; guilt doesn't produce life. ("Recasting the Christ")

I will return to this idea of God as one to be feared in my discussion of Eugen Drewermann. However, Spong has highlighted that there is another element of Augustine's thought that remains hidden from the reader - the psychological element of being a Christian. Because of the Christian message, Christian believers view the world in very different ways than believers of other faiths. For example, Christians believe in a world that was created once, and a world in which 2,000 years ago the Godhead descended down to live amongst us, then rose into heaven only to return to judge everyone at the end of the world. Compare this with a Hindu notion of time that may be cyclical or occurring in much longer cycles than what the Christian Bible portrays. Christians believe in the existence of evil on this planet, as a tempter, Satan, the Devil an actual spiritual entity which is capable of influencing human beings. Other religious systems have no such concept, and what is "sinful" for the Christian can be of no special consequence at all for an adherent of another faith.

\section{Using Girardian Analysis: Mimesis, the Scapegoat and the Uniqueness of}

\section{Christianity}

I think that one way to examine the psychological motivations for Christian pronouncements on war is to look outside the box, away from the obvious texts of the Bible that specifically mention war, and look to the deeper meaning behind biblical 
stories. To that end, I turn to the theories of French philosopher René Girard and others who have tried to find psychological explanations of human behaviour, including warfare, through Biblical analysis, by trying to find out overarching themes in the Biblical narrative. Girard claims there is something in the story of Christ as the victim on the cross that makes Christianity unique.

Girard's hypothesis is that all violence originated because of acquisitive mimesis and rivalry (see Deceit, Desire, and the Novel). Human behaviour can be explained by mimesis, which is an expression of imitation. If one imagines a situation in which two individuals desire the same object, as they both attempt to obtain this object, their behaviour will lead to conflict as there is only one object between them. Writ large, mimetic theory can also be applied to groups of people or states. In desiring the same goals or the same objects, conflict will be generated between the model and the rival (imitator). "Violence is generated by this process; or rather, violence is the process itself when two or more partners try to prevent one another from appropriating the object they all desire through physical or other means" (Girard, "Mimesis and Violence" 9). For Girard, mimesis offers a better explanation for the origin and perpetuation of violence for the range of situations in which we find conflict than other conflict models that may focus on aggression, scarcity of resources, exploitation or colonialism. Aggression and scarcity are not the cause of the conflict, but part of the problem of conflict, since both are limited to only certain types of conflict (Girard, "Mimesis and Violence" 9). Mimesis seems to go to the root of the problem rather than just describe various components that cause violence. 
Girard then identifies the mechanism through which violence was deflected and peace restored in ancient societies. This is the scapegoating mechanism - a violent process through which catharsis is achieved thus resulting in a temporary end to the conflict and a moment of coming together or rapprochement vis-à-vis the groups/people in conflict. There are several conditions for the choosing of the scapegoat. First, the scapegoat is, by definition, an arbitrary victim, at least to the degree that the victim has, in reality, no direct bearing on the problems that are causing the community disturbance. However, the victim is not arbitrary to the extent that most scapegoats tend to have similar cultural traits that allow Girard to classify them as a group. Normally they are an outsider, but on the border of the community, not fully alien to the community. This victim belongs to the community, but has traits that separate him/her from the community. Typical examples of scapegoats include the vulnerable such as children, old people, those with physical abnormalities, women, members of ethnic or racial minorities, the poor, and "those whose natural endowments (beauty, intelligence, charm) or status (wealth, position) mark them as exceptional" (Wallace and Smith 253; see also Girard, The Scapegoat).

Once the scapegoat has been sacrificially eliminated, there is an immediate alleviation of the violence that plagued the community. However, the peace achieved by the scapegoating process is not lasting, nor ethical. Rather, the process only sets up the community for future violence and embeds violence within the framework of a community's ritualised processes. It is important to realise that the community is not even aware of the fact that they are scapegoating or that the scapegoat is an arbitrarily chosen innocent victim. After the sacrifice, the scapegoat becomes identified as the 
cause of the community's problem. At the same time, paradoxically, the sacrificial victim starts to take on miraculous or divine characteristics as a result of the peace achieved. Because the peace achieved occurs so suddenly, actual details of historical events are lost as idealised mythology surrounding the sacrifice begins to overshadow and replace historical knowledge. Eventually, a religious ritual develops by which the original blood sacrifice may be commemorated on a regular basis. This started with human sacrifice, but, with the introduction of Jewish religion, the sacrifice gradually evolved into animal sacrifices and eventually, bloodless sacrifices. This ritual eventually acts as a method for purging violence in the community. This whole process for Girard is an indication that violence is at the root of all religion.

However, what Girard identifies as unique in Christianity is that the story of the sacrifice of Jesus subverts the subconscious component of the mechanism. This is because the Judeo-Christian scriptures counter the general pattern of other historical accounts of religious history in which the scapegoating mechanism appears but is cloaked in the mythological narrative; the Bible represents anti-mythology - the stories in it are told as actual historical events. The Crucifixion is seen as an historic event, therefore, the community becomes aware of the scapegoat mechanism in action. This awareness is heightened by the fact that in the Bible, the victim is the ultimate innocent victim (the Son of God) and the stories are told from the point of view of the victim. ${ }^{35}$ Therefore, eliminating the scapegoat ceases to cause lasting peace. Girard attributes the increasing

\footnotetext{
${ }^{35}$ Girard does not claim to be the first to have noticed the Judeo-Christian emphasis on the victim. He cites Weber (Ancient Judaism) and Nietzsche (The Anti-Christ), who also saw the Bible's tendency to take the side of the victim (see The Girard Reader 149). For example, the whole history of the Israelites as presented in the Hebrew Scriptures is that of an oppressed and victimised people. When the Israelites conquer, they do so not as a result of their own efforts but only through the intervention of their God Yahweh. However, even when they do overcome their enemies it does not bring a lasting peace, but tends only to propagate further unrest and violence.
} 
amount of violence in the modern age with the failure of the scapegoating process, which results in increasingly shorter periods of cathartic peace (see The Scapegoat); also Bailie).

Girard implies that Christians have missed the main message of Christianity, that is, that violence is the result of the scapegoat mechanism, and that in order to conquer violence, we must understand how to conquer mimetic passions and avoid scapegoating altogether. For Girard, the whole Bible represents a moving away from the idea of sacrifice at all by revealing the folly of the sacrifice itself. The solution to the problem of increasing violence lies not in imitating our neighbours (the mimesis that leads to violence) but by imitating Christ and God (see "Violence, Difference, Sacrifice" 22-23). When one realises the problems associated with the scapegoating mechanism, the hope is that there will be a conscious effort to combat it and thus to end the perpetual cycle of violence that it causes. However, although he offers a suggestion on how mimetic desire can be conquered, he never examines how the Bible itself might contribute to continued use of warfare as an instrument of statecraft. By turning to the writings of Gil Bailie and Eugen Drewermann, both of whom use Girard's theory of mimetic desire as a starting point, I will describe how the concepts and beliefs of Christianity contribute a support for the idea of the just war. Earlier in this chapter, by examining Augustine, I described how Neo-Platonic and Manichean influences, his methods of reading and understanding the Bible, ideas of the fallen nature of man, and his interpretations of love are all crucial to understanding how the Christian just war theory was expressed. By using Bailie and Drewermann, I will describe other more subtle aspects of Christian thought that may 
explain why the Christian just war continues to be so influential in the political discourse of so many people and world leaders.

\section{Violence Unveiled: Counteracting Victimhood as a Cause of War}

Gil Bailie describes the "mental and spiritual atmosphere in which we think about our lives" in the West as having its roots in the Bible, and because Western civilisation has now spread throughout the world, the effects of Christianity are to some extent more global than just Western (14). Along with the mental and spiritual atmosphere is a sense of historical consciousness that is also bound to the historicity of the Judeo-Christian tradition. "The biblical sensibility that shaped Western cultures endowed them with a palpable sense that something new was happening in history and an insatiable curiosity for finding out what it was" (Bailie 14). Bailie explains that the European Enlightenment tried to expel or marginalise the religious perspective on life that had dominated before by introducing secular and empirical rationalism rather than looking at religious "superstition". What it achieved was creating in people wariness about religion. However, the cost of removing religious explanations was that "some of the oldest vagaries of the human drama become incomprehensible" (Bailie 12). Perhaps as a result, the Enlightenment was unsuccessful in trying to control or end religiously based or religiously motivated violence. Collective and cathartic acts of violence are still counted on to restore societal calm where there is chaos (Bailie 13). He refers to this kind of violence as "veiled violence" - violence in which religious or historical justifications provide it with respectability and a sense of morality. This veiling also serves to prevent us from recognising the humanity of the victims and the truth about the violence inflicted. 
Conversely, violence is unveiled when these religious and historical justifications are stripped away, and once this happens, "it cannot sufficiently distinguish itself from the counter-violence it opposes" (Bailie 15) and so, it incites more violence.

Bailie explains that what Girard identified as the uniqueness of Christianity, that is, the scapegoat victim is innocent, is what causes people to place emphasis [read: undue emphasis compared to other worldviews] on counteracting victimhood. All the world's religions emphasise compassion and mercy, "[b]ut the empathy for victims - as victims is specifically Western and quintessentially biblical" (Bailie 19). Even campaigns of violence, such as those in Nazi Germany, were justified by asserting protection or vindication of victims. Victimisation can make you the centre of attention. It also "offers absolution and no accountability and creates entitlements to sympathy, support and reparations" (journalist Wendy Haminer qtd. in Bailie 20).

One would assume that an increase in empathy for victims would reduce victimisation and violence. But Bailie states, "[o]n the contrary, by arousing empathy for victims, the biblical tradition has destroyed the kind of peace and social consensus that conventional cultures were once able to achieve at the victim's expense. In clogging the gears of the scapegoating machinery, the gospel revelation brings not peace but a sword" (Bailie 24). This is so because the Gospel destroys the ability to sacralise violence, and the only kind of violence that can end violence effectively is sacred violence. Endowing certain acts of violence with religious significance was a means of ending the violence that would otherwise be relentless. ${ }^{36}$ In a nutshell, Bailie argues: "had [the Western

\footnotetext{
${ }^{36}$ Perhaps the fact that India has named some of their missiles to evoke Hindu deities and the fact that India's nuclear tests were scheduled for the Buddha's birthday are subconscious elements in India of sacralising warfare. This is something to be expected if these dates were picked by nationalist political parties allied with the Hindutva movement, but then they are a reflection of Hindutva and not Hinduism.
} 
world's] exposure to the Gospels not jeopardized its conventional apparatus for turning social discord into camaraderie at the victim's expense, it would no doubt have been more peaceful" (Bailie 24). Bailie does note that the Gospels did have a mitigating effect on violence through some of their moral admonitions such as loving one's enemies, forgiving one's persecutors or turning the other cheek, but overall, because of the erosion of the sacrificial mythology, violence still pervades to a greater extent than it would have without the Gospels.

In order to illustrate what he means, Bailie offers a modern example - the famine crisis in Somalia in 1992. In this crisis, the US sent troops to Somalia in order to alleviate the suffering of Somalis. However, when an American soldier fell victim to the violence, public attitudes in the US changed and troops were withdrawn. Bailie states that the impetus for the US to intervene militarily sprang from the fact that they were "the spiritual and moral heirs of a biblical tradition, the historical effect of which is the gradual awakening of a concern for the plight of victims" (17). He says there was a double dilemma facing the US - a concern for the starving victims, and a concern for their own victims. In previous wars, perhaps the carnage on both sides was not as easily apparent to influence US opinion as the televised images from Somalia were. However, Bailie says that it is not improved technology that creates empathy for victims, but a "profound historical shift represented by the West's progressive concern for victims" that

\footnotetext{
Although, none of the missile names are direct names of any deities, the Sanskrit words could be interpreted as reflecting the power or weapons of various deities. Muhammad Pervez claims that the use these terms in the naming of these missiles are viewed as attempts to identify India with Hindutva and to glorify Mother India based on Hinduism (112). I think that this claim may be slightly exaggerated because when one views all the names of Indian missiles, most seem more abstract: Pritvi (earth), Akash (sky), Agni (fire), Trishul (trident); Agni does not have to be connected to the God of Fire but can be seen as another element like earth and sky; Trishul does not have to be connected with Siva and can be used generically.
} 
used technology to disseminate the faces of victims (20). He goes so far as to describe this concern for victims as "the principal moral gyroscope in the Western world" (10). It is this empathy for victims that is the source of "moral uneasiness and social restlessness" in the West (19). One of the primary sources of this empathy is the Crucifixion of Jesus which "invites those it confronts to see scapegoating violence for what it is and to recognize their own complicity in it. By acclaiming the victim as Lord, the Gospels slowly begin to awaken an empathy for victims everywhere" (27). As I have already discussed in the previous chapter, initiatives like R2P, which continue to be modelled on the Augustinian framework of just war, reflect just what Bailie was describing in 1995 . $\mathrm{R} 2 \mathrm{P}$ is a declaration to purportedly protect victims through warfare.

\section{The West, Victimhood and Failure of the Scapegoat Mechanism}

Bailie views this Western preoccupation with the victim as victim as an unnatural and a cultural phenomenon. In fact, he says that people will try to suppress their feelings of empathy. Nietzsche claimed that for countries influenced by Christianity, this empathy for the victim eventually threw their cultures into disarray. His solution is to purge the Gospels and to revive the traditional sacrificial structures (31). Christianity's creed as well as its scripture all focus on the Crucifixion, claiming that this one event gives the human race a new lease of life, although those who do not believe will be separated from God. The insight from the Crucifixion is that the victim was innocent and his persecutors wrong, and also that the victimisation itself brings peace to the community. For Bailie, this is a radical change from the stories of the Old Testament 
because "it suppressed neither the moral offensiveness of the violence nor the social fact that the violence had beneficial cultural effects" (45).

In other words, what the Crucifixion appears to do is to remove the religious aura of violence for all other acts of violence, thus, the spectacle of violence has no effect of reverence on the onlookers. Therefore, because of mimetic desire, the most entranced onlookers will then attempt to replicate the violence. ${ }^{37}$ A sacrifice ritual that may have "worked" in a pre-Christian antiquity did so by transferring the antagonisms of a community onto the victim against whom the society could unite, and this act strengthened social bonds between the group. However, "when a culture's sacrificial routines fail to generate this combination of camaraderie and moral rectitude, the existing rivalries fester and the social fabric begins to fray" (88).

In summary, sacred violence ends in catharsis, satisfying the appetite for violence that its preliminary rituals awake (90). However, if those witnessing violence fail to achieve catharsis, their appetite for violence remains and the violence that it has failed to quench will merely be replicated again, in other words, instead of catharsis, one finds imitation or mimesis. Bailie refers to mimesis as the "fiercest and most enthralling form of violence. We cannot understand violence, and we cannot begin to understand the role it has played religiously and anthropologically, until we understand the mimetic mechanism that produces violence and gives it such mystifying power" (95).

In Christianity, Jesus becomes the scapegoat for all of humanity. However, unlike in the past, now, there is empathy for the victim, and this becomes "a source of

\footnotetext{
${ }^{37}$ Bailie offers the example of sixth graders from a California school following the Rodney King death. During the lunch break, one black student said that he wanted to be Rodney King for Halloween, after which, a boy tripped him and then various other (non-black) boys began kicking him singing "Rodney King if falling down... My fair black man" to the tune of "London Bridge" (87).
} 
immense perplexity to the society formerly united in its contempt for him" (Bailie 94). Therefore, for Christians especially, the most sanctioned forms of violence lose their ability to restore order, while the mimetic power of violence still remains (99). In the Christian age, we lack the sacrificial mechanisms of old that "can convert all our mimetic passion into social unanimity, psychological stability, and a renewed sense of moral rectitude" (108). Therefore, in the modern world, these mimetic desires linger on, with no scapegoat on whom these desires can be focussed and driven out, or deified. Biblical texts have stripped the sacredness from sacrifice, and we are forced to empathise with the victim. Bailie does not bemoan the collapse of the sacrificial system, but rather fears that the corresponding rise in mimetic passion (jealousy, envy, covetousness, rivalry, resentment, contempt and hatred (Bailie 112)) is something whose consequences may be catastrophic.

\section{Historicity of Christianity}

Many scholars note that the stories of Christianity of a resurrected God-Man mirror other myths in the Near East. However, there is a refusal to interpret the stories of mob murder as anagogic metaphors, since Christianity roots its stories in actual historical events. In other myths, the sacrificial murder inspires the perpetrators to remember the murder as holy and creative. However, in the Gospels, it is the plotting of Judas, the kangaroo trial of Jesus and the weakness of a denying Peter that is remembered. The result is that Christianity "has no tool at its disposal for deciphering the scapegoating and sacrificial nexus at the heart of mythic reality" (Bailie 131). Bailie goes so far as to say that Western culture - what he calls the world's first counter-cultural culture - is defined 
by the fact that biblical empathy for victims caused an interest in the "actual historical events" of the Bible. Western historical realism is rooted in the historical "fact" of the Crucifixion, however, what Bailie implies is that the religious and anthropological journey that leads to Golgotha is not fully understood (131). What is not understood is Girard's original idea that the story of Jesus was meant to expose the existence of the scapegoating mechanism. What instead is more apparent (especially when looking at the Old Testament) is that the Bible does not camouflage the violence, even if the violence described would make the reader shudder. Perhaps this idea of world history being told in the stories of the Bible adds legitimacy to the idea of the just war - the idea that just wars go back to the story of Moses and the Egyptians. As Andrew Fiala states:

Political life is organized around mythic stories that color our perception of reality. Thus just war myth - the idea that wars are actually just - is often tied to a political myth that claims we have justice on our side. Mythologized history makes it appear that there have been just wars in the past; this convinces us present and future wars must also be just. (15)

\section{Bailie's look at the Hebrew Bible - The Fall and Mimetic Desire}

In Christianity, the essential teaching about the human race is its fallen nature. This arises from one of the first narratives in the Bible - the story of the first humans in the Garden of Eden. Bailie describes this story as one of contagious desire - a story which exemplifies the idea of mimetic desire at the onset of creation. The serpent inspires Eve to see the fruit of the forbidden tree as "pleasing to the eye" and the desire for eating it is to become like God. In terms of mimesis, therefore, there is a mimetic desire for the fruit and mimetic rivalry and resentment towards God. The tree is just a literary device for making mimetic desire and resentment more intelligible in the context 
of a narrative. It is a test case for humans, the test being "whether or not humans can tolerate even the most innocuous form of self-restraint and even the most beneficent form of transcendence without becoming resentful and rivalrous" (Bailie 137). However, humans fail this test miserably, and Bailie questions that if we fail and disobey a divine creator, how much more impossible will it be to control our desires and rivalry when faced with a fellow human's social prestige or other enjoyment.

Genesis 3:6 describes the eating of the fruit. In verse 12, Adam scapegoats Eve and in verse 13, Eve scapegoats the serpent. Bailie summarises the effects of this saying that "the story is about how we humans fall into an alien and duplicitous relationship with God and one another because of an inability to be in the presence of the "other" whether human other or the divine Other - without succumbing to envy, resentment, guile, and dissembling (Bailie 138).

Other examples of scapegoating victims that Bailie mentions are Abel, Isaac (whose sacrifice God ultimately stops), and Egyptians slayed during Passover by the angel of death. When such an Israelite institution as the Temple of Jerusalem built by Solomon became established, it became the centre of Jewish life. During this time, animal sacrifice was very much a part of ritual Jewish life. One special sacrifice described in Leviticus, chapters $11-16$ is the origin of our term "scapegoat" - a translation of the Hebrew word azazel (לזאזע). There was a ritual in which two goats were chosen, and lots were cast to determine which will be sacrificed to Yahweh in atonement for sin. This goat is driven into the desert to die. Bailie explains that this scapegoat mechanism was a "liturgical innovation" that was designed to avoid death of a person (see Bailie 149-52). 
However, if the priestly rituals were ineffective in deflecting violence, then it was directed towards external enemies. Therefore, the religious rituals were augmented and complemented with the sacrificial idea of Holy War. It seems like there is a Eureka moment when the realisation is made that the nearby alien cultures provided an almost limitless sacrificial outlet (Bailie 158). Uniting together against a common enemy generated an esprit de corps. Bailie questions why, when other cultures would have plundered material wealth, animals and slaves, did the Israelites demand annihilation? Referring to Girard, Bailie says that this is to avoid the generation of mimetic rivalries that the pillaged booty would have caused amongst the victorious Israelites. However, this is just an indication of a weakness in the sacrificial system because "it is based on the fear that the social solidarity engendered by the war is too fragile to survive the envy and acrimony likely to be provoked by an influx of plundered goods" (Bailie 161).

\section{The Evolution of the Anti-Sacrificial Impulse: Jesus and the New Anthropos}

With the story of Jesus, Bailie compares his temptation to that of Eve in the garden. However, unlike Eve, who gave in to mimetic desires to be like God and ate of the fruit, Jesus does not succumb to the temptation by Satan in the wilderness and refuses to display any of his divine nature. It was because Jesus remained God-centred that those mimetic desires were resisted (Bailie 203). In rejecting temptation, Jesus is denying the world and denying conventional human culture. He is calling for a spiritually-grounded, God-centred life not a culturally-grounded one because a life grounded in culture will only lead to sacrificial altars because it "sows discord by arousing mimetic passions and then exacerbating the social tensions and the psychological apprehensions that 
accompany such passions" (Bailie 206). Eventually, man-made kingdoms crumble and are replaced. Christian tradition says that Jesus as God-incarnate was like us in all things but sin. Bailie explains Jesus' sinlessness by correlating it to his God-centredness. Jesus was able to overcome temptation not through sheer will alone but by replacing the mimetic desire (of the devil) with another mimetic desire - the desire to do his father's will, "to become the image and likeness of the One in whose image and likeness he knew himself to have been made" (207). This is the ultimate message of Christianity, albeit one which is missed because of Christianity's linking of salvation with belief. Many of these exclusionary ideas of Christianity only serve to create new scapegoats. One of these scapegoats were Jews, who were persecuted and portrayed as killers of the Messiah and the Son of God. This in many ways is a failure to recognise not only Jesus' own Jewishness, but the fact that many of the early Christian community never thought of themselves as anything but Jewish.

Jesus was constantly breaking barriers in traditional Jewish society. He shared his meals with sinners and outcasts such as prostitutes and tax collectors. This was a message to others that a change in attitude, a transformation of the heart was necessary. For many Biblical scholars, the miracle of the multiplication of loaves and fishes is not so much a literal miracle but an indication that Jesus convinced a large mass of people to forget their cultural differences and eat a meal together (Bailie 214). He often cured people inflicted with disease, who were considered by Jewish society as social pariahs, and afflicted because of their sin or the sin of their parents. By curing these people, Jesus eliminated the social ostracism of disease and restored the dignity of those in danger of becoming scapegoats (See Bailie 216). The life, ministry and death of Jesus were an 
attempt to refashion or transcend human nature. It was an attempt at "softening the human heart or refashioning the human self" by overriding the social and psychological reflexes relied upon and reinforced from the beginning of time. It was an attempt at rooting out mimetic desires and therefore eliminating conflict and violence by a focus on a non-earthly kingdom - essentially, a focus on care of the soul rather than care of the body.

Unfortunately, Christianity itself revived the structures of sacred violence that the Crucifixion had exposed. In attempting to reclaim the holy lands from the "infidel", Pope Urban II launched the First Crusade and the very structures of sacred violence that the Crucifixion had exposed were revived. Bailie compares this non-recognition of the significance of the resurrection to the non-recognition of the risen Christ by the disciples on the road to Emmaus (Luke 24:13-35). He says that the various words that come up when discussing war, such as "nationalism", "civil war", or "ethnic cleansing” are merely a "recrudescence of the primitive sacred as though it were something less ominous and significant than it is" (Bailie 262). In the "new nationalism", religious issues are either explicit or just beneath the surface. However, in the West, it is nationalism that takes precedence over religious issues and attempts to claim moral impunity by appealing to Christian ideals have not been successful in ending violence. Instead, Christians are forced to look elsewhere in attempting a "sacred" justification. Thus, race, ethnicity, nationality and ideology are endowed with religious significance and these terms provide those in a secularised or Christianised world with a facsimile of the sacred (264). ${ }^{38}$ Bailie

\footnotetext{
${ }^{38}$ Bailie notes that in 1994, when Michael Ignatieff visited the Balkans, his descriptions of the violence seemed almost akin to the sacrificial rituals that Captain Cook encountered in Tahiti, except that they were devoid of any religious connotation, and the number of victims was far greater. There were still myths in play that unleashed this violence and endowed it with moral legitimacy. For example, Serbs painted all
} 
notes that even societies that have not been in direct contact with the biblical tradition are affected by this problem.

This is so because the secularism that these societies are trying either to foster or slough off is a thoroughly Western phenomenon, suffused with biblical moral sensibilities, both those it repudiates and those it claims to have invented. Since, then, Western secularism carries the biblical virus it eschews, by the time a society has been affected by it enough to either embrace or react against it, it has already been infected to some degree with these biblical sensibilities. To exactly that degree, its sacrificial apparatus will be destabilized and its justifying myths will be undermined. (263)

For Bailie, the resurgent nationalism of the post-Cold War era was a symptom of a religious crisis, what he calls "a crude and sometimes violent cry for transcendence" (original emphasis). Although, especially in the West, religiosity seems to be on the decline, Bailie states that human beings are innately religious creatures, and he cites Augustine who said, "We are restless until we rest in God" (270). The term "war", for Bailie, "carries some of the vestigial power of the sacred" and the myths that are used to justify scapegoating or sacrificial violence are a product of the primitive sacred (267). War provides the semblance of religious transcendence that its perpetrators and spectators crave, although this kind of transcendence is inauthentic. The only way of eliminating war is to discover or rediscover more authentic forms of religious transcendence (271). However, in modern times, this connection between war and the sacred seems to be lost. When Pope Urban II launched the First Crusade, the battle cry of his troops was "Dieu le veult" (God wants it). Today, this connection is lost, and so the violence never ends. Christianity appears as a hindrance to the sacrificial catharsis of 
ancient religions. Thus, a Christian viewpoint may only serve to exacerbate the need for violence.

Now, I will turn to the works of Eugen Drewermann. While Bailie's analysis centres on the breakdown of the scapegoat mechanism and the creation of empathy for victims as contributors to warfare in the Christian psyche, Drewermann focusses on fear, especially the fear of a violent God as portrayed in Biblical stories.

\section{Eugen Drewermann and the Role of Fear in Christianity}

Writing in decades after the atrocities of the Second World War, German theologian and ordained Catholic priest Eugen Drewermann, came to question the traditional views of God as an omnipotent ruler and as a guarantor of moral law (Beier 9). Some of the questions asked by Drewermann include the following:

Does religion need to do violence to the self in the name of selfrenunciation and sanctify suffering in the name of bearing the Cross of Christ? Is the God of Christianity categorically opposed to human desires and to human self-realisation? Does this same God sanctify the killings of millions of people in wars declared to be "just" by the Churches? Does this God legitimise the violent exploitation of nonhuman nature and the aggressive, economic exploitation of non-Christian cultures and countries in the name of a secularised religious ideal of "Be fruitful and multiply, and fill the earth and subdue it: and have dominion... over every living thing that moves upon the earth" (Genesis 1:28). And, above all, is the Christian God of love and grace also a God of violent justice? (Beier 12)

Drewermann contends that Christianity uses fear as a prime motivation for faith: fear of hell, fear of being excluded from the (dominant) social group, fear of losing one's status and fear of God. This fear is responsible for keeping people in line with the interpretations of doctrine by church leaders and officials. Drewermann believes this to be contrary to the message of Jesus who healed through trust (not fear) and who himself 
questioned the religious and theological elite of the time who used fear and intimidation mainly to secure their own power (Beier 12).

Drewermann's first inklings of doubt in the teachings of the Catholic Church arose while still a teenager in post-Second World War Germany. In 1956, Pope Pius XII declared (in response to the fears of an invasion of Western Europe by the atheist Soviet Union) that under the circumstances of the time, no Catholic called upon by an elected government had the right to conscientious objection to military service. Pius XII may have even justified the use of nuclear weapons against this atheist and communist threat (Beier 19). However, Drewermann was opposed to any participation in military action and saw a conflict between following his own individual conscience and the Church's claims to know about the duties of the individual with absolute and divine certainty. Looking back historically, he questioned why a country like Germany, steeped in the Christian tradition, could be swept away by the destructive ideology of Nazism which used some of the most cherished ideas of humankind (such as duty, allegiance and obedience) to perpetrate some of the worst crimes against humanity (Beier 127). It is not only Nazi Germany, but the whole Christian West that Drewermann questions as the most extreme means of human aggression, such as the atomic bomb or the Nazi extermination camps, originated in the West (Beier 135-36). Drewermann's writings attempt to show that the violent image of God in Christianity is partly responsible for the failure of the Church to prevent the atrocities of Nazi Germany, and in fact, the Church's theology may have contributed to the reasons why so many people gave blind obedience to Hitler. As Beier states, "Drewermann's work essentially tries to understand how a 
sacrificial theology could lead people to obey in the name of duty rather than to rebel in the name of humanity" (25).

Drewermann's exegesis of Biblical texts relies not only on historical-critical scholarship and structural analysis but also "on an empathic verbalization of the feelings and motives between the lines, because "we can understand the present text only if we read it with 'the inner eye,' feel it, apply it to ourselves and let it affect us deeply". To this end he employs the method of client-centred psychotherapy (Gesprächspsychotherapie) which reflects on what the statements of one person mean to another person, "which feelings, wishes, hopes, worries, etc." they imply (Beier 38). His textual exegesis implies that a historical-critical perspective is insufficient and that it needs to be

supplemented by anthropological methods which may shed light on the universal significance of the concrete imagery of the mythical material of the story. Drewermann hence turns to the comparative study of mythology and ethnology to research whether the motifs [in the text] [...] show similar meanings in different cultures, preferably in cultures which are historically unrelated, and to depth psychology for an interpretation of the anthropological meaning of these motifs. (Beier 47)

\section{Fear as the Root of War}

For Drewermann, the "most profound and most original motif for war" is the "principle of territoriality" (which humans share with animals) which he defines as the aim of animals and humans to defend a certain territory needed for hunting food and for the protection of females and offspring within secure and inviolable borders. As humans 
proliferated in search of new territory, races ${ }^{39}$ developed in response to climatic requirements for survival (biological adaptation). Originally, the earth was populated by discrete and isolated communities, however, eventually these disparate communities would encounter each other, and the biological adaptation that was once a benefit to them became a psychological source of conflict. The fear these communities had was that an outside community would take away resources that belonged to them, consequently worsening or endangering their lives. Killing other humans in battle is, therefore, a function of trying to prevent future danger (Beier 139). Drewermann then looks at how the Bible reveals the connection between fear and violence.

\section{The Fall: The Origin of a Violent God-Image}

As with Augustine and other thinkers before him, Drewermann starts with the story of the Fall to determine Christianity's portrayal of the relationship between God and man. He mines the Fall story for evidence of his hypothesis that the Church's political teachings are ultimately the result of the violent God-image found in the Bible which influences Christian psychology (Beier 33). Genesis 2 relates a time in which humans lived in harmony with God, with the earth, and with themselves. There is a complete dependence on God, and perhaps this is what it is like to be truly human. However, Genesis 3:1 introduces the serpent who is described as being one of the most subtle or crafty creatures created by God who questions Eve saying, "Yea, hath God said, 'Ye shall not eat of every tree of the garden'?" Drewermann describes this as painting a tyrannical God-image by the incorrect question suggesting that God forbade humans to eat from any

\footnotetext{
${ }^{39}$ Drewermann defines race paleoanthropologically as a "(once) isolated community of procreation [Fortpflanzungsgemeinschaft $]$ (Beier footnote on p.138 quoting Drewermann).
} 
of the trees, although God's original statement to Adam and Eve was that they could eat from every tree except the tree of the knowledge of good and evil (Genesis 2:16-17). However, the serpent distorts the God-image claiming that God only gave the command out of jealousy to prevent humans from becoming like God (Genesis 3:4). Eve attempts to correct the serpent after he asks the incorrect question because she does not want to disobey God. However, she seems to remember God's command incorrectly as the original interdiction is merely against the eating of the fruit, but Eve tells the serpent that in addition, if they touch the tree they will also die. This shows that "against her will, the woman's trust in the goodness of God has already been shattered at this early stage of the story by the image of prohibition which the serpent has painted of God. She can recall the words of God only within a feeling of fear" (Beier 39). By subconsciously increasing the prohibition to include touch, Eve indicates in her response to the beguiling serpent, a desire to eat the fruit has already been aroused in her, although this desire is initially resisted for fear of losing God. The most important point for Drewermann is that the serpent succeeded in distorting the image of God so completely by fear that for the first time, humans feel that they can no longer completely depend or rely on God, but rather, God himself is seen as a source of fear and anxiety. "What was stated in the original commandment as a simple consequence, receives in the exchange between serpent and woman the quality of anticipated 'punishment' from God" (Beier 39).

For Drewermann, this is an indication that the original motive for sin is not pride, hubris, or a desire for autonomy or undue self-assertion, but fear $^{40}$ of a violent God (Beier

\footnotetext{
${ }^{40}$ Drewermann distinguished between three levels of fear: biological, psychosocial and spiritual (existential). Biological fears are those we share with animals, such as fear of starvation, being trapped, being segregated or abandoned. The reflective capacity of human consciousness makes it possible for us to isolate biological fears from their immediate situational context and transform them into psychosocial fears
} 
38-39). The serpent identifies the threat of death with God, and poses as the giver of life to Eve by promising that she will not die if she eats the fruit, but will be like God. The result is that God is portrayed as powerless. A heteronomous ${ }^{41}$ image of God is created. From the serpent's description, God is somehow jealous of the power of humans who have to be suppressed by an interdiction. (Although, from God's perspective is the possibility that the interdiction was made to genuinely protect humans from unforeseeable misery). This heteronomous image gives humans a feeling of equality with God, creating an image that God has to fear humans. At the same time, what was once a fear of losing God turns into a fear of God, and then the compensatory desire to become like God because they have lost sight of who God really is and are now ashamed of who they are. This provides enough impetus to remove or reduce the woman's inhibitions to eat of the tree. The tree becomes desirable - perhaps the epitome of what is desirable. Adam's acquiescence and subsequent sharing of the fruit is seen as the result of mere mutuality, that was originally a source of joy and a force for the coming together of man and woman, but the eating of the fruit turns this mutuality into a source of guilt and a force that separates man and woman by shame (Beier 40-41).

Now, although God continues to walk with humans as in the Garden, humans can no longer see God except "in the twilight of ambivalence" (Beier 43). Humans now, rather than seeking out God, choose to hide themselves from God because of their shame. God calls out, "Where art thou?" (Genesis 3:8) to the first humans not because he does

present even when there no external threat but only an internally perceived danger. However, human existence is also characterised by spiritual needs and dangers wherein the biological and psychosocial fears are expanded into more fundamental fears which characterise human existence itself and is an expression of the fact that the "human being is the only living being which has and must have questions which cannot be answered by biological needs" (Beier 132-33).

${ }^{41}$ Heteronomy refers to action that is influenced by a force outside the individual. 
not know their whereabouts but because he is trying to get an admission of guilt from man and thereafter, to restore the relationship between himself and humanity. However, rather than admit wrongdoing, Adam immediately blames Eve, and in doing so, even implicates God in his own wrongdoing by saying "the woman whom Thou gavest to be with me, she gave me of the tree, and I ate" (Genesis 3:12, emphasis added) and Eve similarly passes the buck saying "The serpent beguiled me, and I ate" (Genesis 3:13). Eating the fruit did not result in a change of the world, nor in a change of God, but in a change in the human experience of the world and of God which "consists in nothing but a complete reversal of the quality of all existing structures of human life" (qtd. in Beier 44). The result is that "both the world and God appear in a world 'without God' as adversarial" (Beier 44). Life is now a battleground between good and evil. Human labour turns into miserable toil and procreation a painful burden. But there is also another consequence: in interpreting the adversity of nature as a punishment from God, although due to human fault, ultimately it is God who is seen as causing this adversity. The confidence that humans have in God is shattered by the Fall. God is experienced as an arbitrary dispenser of blessings - a being whose behaviour is capricious and unpredictable and not as the source of only goodness.

The flip side of this is that this adversity also leaves open the possibility of salvation (in breaking the cycle of fear and its adversarial consequences) through another act of God. The stories in the Hebrew Bible seem to show that after the Fall, humans distanced themselves further from God, and God is portrayed more as a jealous and vengeful God, yet there is also some sense that God wants to save humanity from this vicious cycle (Beier 45). And this eventually occurs through the Crucifixion. 


\section{The Relevance of Fear}

Drewermann's observations about the fear instilled in Christianity do seem to provide motivation for human action. If a person is fearful about the status of their eternal soul after their life on this planet is complete, that person may take drastic steps to ensure that their afterlife will be a positive experience. During the Crusades, the concepts of pilgrimage, penance and just war theory were transformed into the notion of the holy war fought by soldiers of Christ for personal salvation. Maybe people thought of the Crusades as a new kind of war characterised by the spiritual benefits that accrued to combatants who died or who killed the enemy in battle (Bachrach 108). Fear may have been a motivating factor for many people to join the armies of the Crusades.

The writings of Augustine also demonstrate the importance of fear as a motivating factor for action. French historian Jean Delumeau recognised that Augustine's teaching on original sin was responsible for the fact that even during the Renaissance the Church kept alive the fear of God's 'colère fantastique', which was caused by the pride of Adam and Eve and led to the cosmic catastrophe in which we now live. The metaphysical fear, caused by emphasising the role of Christ as Judge, remained alive and determined the identity of Europeans from Antiquity through to the Renaissance. Another French historian, Philippe Ariès also blamed Augustine for affecting the Christians' original trust in God's mercy and increasing their fear to end up in the power of Satan for all eternity (Van Geest). These observations may sound exaggerated, but I believe that they do corroborate Drewermann's findings about the importance of fear in Christianity. 
One of the seven gifts of the Holy Spirit that Christians are thought to receive is the gift of holy fear. This kind of fear is contrasted with other kinds of fear that are not from God. For example, in his article "Theology of the Laity: Gifts of the Holy Spirit", Father Reginald Martin, O.P. describes four kinds of fear that we experience in our lives. The first is worldly fear, which is the apprehension of losing tangible goods (objects) as well as intangible goods (honour, benefits, privilege, position in society). This kind of fear is not confined to Christianity, but I think can be found in all cultures and in all times, and many religions try to counteract this fear. Augustine and St. Thomas reasoned that because the object of this fear is so ignoble, it is evil:

...worldly love is, properly speaking, the love whereby a man trusts in the world as his end... Now fear is born of love, since man fears the loss of what he loves, as Augustine states... Hence worldly fear is that which arises from worldly love as from an evil root, for which reason worldly fear is always evil. (ST II-II 19.4)

The second fear is servile fear - the fear of the wrath and vengeance of God. Augustine observed that those who exhibit this fear shun sin, not because they love God, and not because they hate sin, but because they fear God's punishment. This kind of fear is best characterised perhaps by Jesus' parable of the Good Samaritan. The priest and Levite who ignored the robbed and injured Samaritan operated under an ethos of a servile fear - fear of inciting the wrath of God by veering from the strict letter of the law. Thomas says that the slave-like quality of this fear limits its power to ennoble us. Those who labour under servile fear may lead what appear to be outwardly virtuous lives, but until this fear is mixed with piety and liberated with true love for God, it is imperfect and, like imperfect contrition, it is based on dread of punishment rather than dread of offending God. This kind of fear leads to crippling personal scrupulosity and spirit of 
harsh judgment, it is neither personally satisfying nor a source of peace or growth in the Christian community. In many ways, this kind of fear may describe how religion is used as a justification for war. It is the same kind of fear that may describe why Eve succumbed to temptation and ate the forbidden fruit, according to Drewermann's analysis. It is a fear created by the violence-of-God image in the Bible and while perhaps not unique to Christianity, I believe that this kind of fear is one that all three Abrahamic faiths share.

A third fear is "initial" fear which is the beginning of true, virtuous, fear of the Lord, and this enables us to outgrow servile fear, and to see beyond the limits placed by worldly fear. St. Thomas Aquinas says that "if a man turn to God...through fear of punishment, it will be servile fear; but if it be on account of committing a fault, it will be filial fear, for it becomes a child to fear offending its father. If, however, it be on account of both, it will be initial fear, which is between both these fears (ST II-II, 19.2). This leads to the final kind of fear - holy fear - what Catholic theologians refer to as a gift of the Holy Spirit. This kind of fear motivates action not because of fear of punishment for doing wrong, and not because of the promise of reward for doing good, but because our love for God makes us want to do God's will more and more. This is Thomas' filial fear - akin to the fear of a child who is dependent, loving and obedient to its parent rather than the servile fear of a slave towards a master. However, while Catholic theology is ready to label this fear a gift from the Holy Spirit, Father Martin's explanation only seems to confirm Drewermann's hypothesis that it is also dependent on an individual's ability to realise that mankind is essential sinful in the eyes of God because of the inheritance of original sin. Accepting this "gift" also means accepting Augustine's 
notion of politics as a remedy for our fallen condition, and therefore, by extension, the necessity of warfare in an imperfect world. Describing fear as a gift of the Holy Spirit only reinforces the psychology of fear that Drewermann characterises Christianity as having.

\section{Other Psychological Motivations for War: Gender and Sexuality}

Drewermann views the general sexual repression and the historical suppression of women in Christianity as another link to the motivations for war. Christianity's strong repression of sexuality led to "reactively strong aggressive sadomasochistic impulses", for example, in the witch-hunts between 1400 and 1700. However, after engaging in some cross-religious comparisons, Drewermann seems to question this reasoning, as he says that when looking at religions such as Islam (more sexual freedom) or Buddhism (sexual asceticism) that one would expect less or more belligerence respectfully. In addition, the sexual revolution of the 1960s in the West did not make Western populations more peace loving. Therefore, Drewermann concludes that "it is not the suppression of sexuality but the suppression of women in a society ruled only by men which could indeed encourage wars" (qtd. in Beier 176). Consequently, Drewermann believes that "the attitude toward human sexuality will find a solution on the part of Christianity only if Christianity could give up its historical battle of despair against the inner nature of humans, against the unconscious as a whole and against the feminine of the human psyche in particular" (Beier 184).

For Drewermann the suppression of women and of female sexuality is the flip side of the anthropocentrism, rationalism and patriarchal reduction of religion in 
Christianity. The Biblical narrative represents an "obsessive-compulsive splitting of the feminine into the roles of Madonna and whore" (qtd. in Beier 184). The patriarchal attitude, he says, is rooted in sociological roles during the pre-historical hunter-gatherer period when it was the "duty of men to kill life and the task of women to give birth to life" (qtd. in Beier 176). A patriarchal society favours characteristics associated with hunting, and psychologically, this is important in answering the basic religious questions of what it means to exist as a human. "The overvaluation of the father-image means psychologically that human recognition and acceptance is primarily bound to achievement and diligence rather than bestowed unconditionally because of one's mere existence" (qtd. in Beier 176-77). This does not mean that matriarchal societies are more peaceful or that women contribute less to the psychology of war. Drewermann argues that women are not psychologically more peaceful, however, the execution of wars is primarily or even exclusively a male business. Men conduct wars with women in mind to protect them and to receive their admiration and recognition, and to be more sexually desirable to them. Related to this idea of suppression of women, it is worth noting that unlike other belief systems, the Abrahamic religions do not have the idea of a female deity, although all three recognise that God is without gender. Yet, especially in the New Testament, God is portrayed as male, a Father. God first creates man, and then woman only as a helpmate. Finally, God sends his only Son to save us. Notwithstanding the story of many women in the Bible, notably Mary the mother of Jesus, Mary Magdalene and other female followers of Jesus and preachers in the early church, Christianity is essentially a male story told by males. 
According to Drewermann, along with the patriarchal suppression of women was the repression of the female aspect in the human psyche, that is, "a certain aversion to and shying away from the emotional possibilities and values in personal and public life" (qtd. in Beier 177). The rationalism of the patriarchal attitude leads to a devaluing of psychic phenomena which are not rational, leading to a creation of a religion of reason. All rites, images, sacraments, mystical and mythical elements were gradually banned and substituted by clear laws and instructions, thus Christianity "cut off the world of religious experience from psychical foundations and transformed it into a system of psychical alienation, of institutionalised suppression. Especially through the Christian way of talking about peace, a human type had to emerge which is technologically more civilized and psychically more barbaric than can be imagined" (qtd. in Beier 177).

\section{The Consequences of Fear in Fostering War}

Drewermann states that

the cruelty and frequency of wars in the Christian West [are] not a chance event but have to be considered symptomatic of the inner sickness of Christianity.... [The] inner inculcation toward war in Christianity ... [is] the more surprising and alarming, since in its words Christianity has shown and seems to want to show extraordinary support for peace. (qtd. in Beier 152)

Beier notes that Drewermann's charge is not only against the direct influence of

Christianity and is not bound to Christian institutions and churches but instead reflects the "neurotic" attitude which dominates the once Christianized world in secularized form; it affects any person cultivated within a Christian area of influence (153). He detects a "neurotic reversal of aim and result in Christian peace efforts" in the contradiction between a subjective will for peace and an objective sanctification of war, and he 
attributes this to the Fall from God due to the fear of the human spirit. This fear is the conscious or unconscious fear of death, which is not so much the fear of physical death but rather "a fear that one's existence is ultimately insignificant and lacks an absolute justification, a fear - theologically - of a loss of relationship with the absolute person who can give foundation to one's existence" (189). In war, this is the fear expressed when the significance of one's existence is questioned, for example, violation of national dignity, questioning of status, threatening or competing ideologies, or claiming of perceived rights, which leads to a desire to see the rival dead.

\section{Anthropomorphism, One Sided Rationalism and Radical Anthropocentrism}

While first prefacing the fact that the Bible has human limitations, Drewermann locates the belligerent effects of Christianity's attitude in the text itself in the way that God is portrayed. For example, the Bible often describes God as physically anthropomorphic (that he sits on a throne, for example) as well as psychologically anthropomorphic (that he is jealous, vengeful, shows favour on some select individuals, and intervenes in the world through plagues and storms to keep humans in check) (Wright 218). This represents a radically anthropocentric view of God, which perhaps can be traced to both its Hebrew as well as Greco-Roman influences. If God can be vengeful towards some groups of people, then humans can too, if they are doing so in accordance to God's will. In this way, warfare can easily be interpreted as mankind acting as an instrument of God's will. 
Greek philosophical influences in Christianity also contribute to its one-sided rational attitude. For the Greeks, the rationality of thinking destroyed the spiritual basis of the old faith in the gods. They also partitioned human history from an external natural history, thus alienating humans from nature. Thus, humans became estranged from both internal and external nature. Human reason became the measure of all things, and nature was emphasised as an ensemble of rational laws. This worldview was adopted by the Romans who combined it with "a tremendous will to rule," creating a mentality where "nature as a whole is declared practically to be a mere resource for human goals" (qtd. in Beier 154). Christianity, which became the political and cultural heir of the Roman Empire, incorporated this idea of rational "natural" laws, and intensified Roman anthropomorphism because of its Hebrew influences of an anthropocentric God-image and also because its main dogma was that God had come down to earth as a human in Christ.

Drewermann also sees this generally estranged and violent attitude towards nature due to radicalised anthropocentrism of the Abrahamic faiths of Judaism and Islam. These religions characterize everything, including God, as centred around humans (see Beier 157). The anthropocentric nature of the Bible is further exemplified by the relationship created between God and humans. The Hebrew Bible sets "the relationship between God and humans purely anthropocentrically into the center of its theological reflection" (qtd. in Beier 155). It associates God with its own patriarchs and a specific nation: "In the center of this religion stood solely the human being and the history of a single people". This creates, in the eyes of Christians, the notion of uniqueness amongst God's creation. 
From a Christian standpoint, the idea of history itself can only be related to the affairs of man as natural history as the history of other life forms is of no real consequence.

The radicalisation of anthropocentrism increases with the Christocentrism of the New Testament. First, the notion that God became incarnate "set[s] humans theologically even more firmly in the center of the world than had been the case either in Judaism or Hellenism" (qtd. in Beier 155). Second, unlike the God of the Hebrews who was concerned with the fate of his (chosen) people, the God of Christianity was concerned with "the fate of each individual, just as Christ had been an individual" (qtd. in Beier 155). This anthropocentric worldview has devastating effects on both the treatment of non-humans and humans and this is tied to Drewermann's psychological explanation. The anthropocentrism fostered an attitude of fear, violence, and exploitation toward external nature, as evidenced, for example by the inhumane treatment of animals in the Western world. $^{42}$ Locating the origins of war in the hunting of animals as he does, Drewermann sees a link between the mass slaughter [Schlachten] of higher mammals in the West and the slaughtering of fellow humans in war. ${ }^{43}$ Drewermann notes that although one can argue that there are different metaphysical or ethical reasons to distinguish between the slaughter of animals and the killing of human enemies in war, the killing of a higher animal is

\footnotetext{
${ }^{42}$ Notwithstanding that inhumane treatment of animals may occur anywhere in the world, perhaps Drewermann's observations might lead us to expect that there would be fewer incidences of war in cultures holding worldviews where vegetarianism is common (e.g. Hinduism, Buddhism and Jainism).

${ }^{43}$ It is worth noting that even when science was beginning to discover man's true place in the cosmos, these ideas were suppressed if they did not agree with scriptures. When Galileo pointed out that the earth was not the centre of the universe, but that like other planets, the earth revolved around the sun, he was persecuted and forced to recant by the Catholic Church. Similarly, Darwin's attempts to put man on an evolutionary continuum with the rest of creation was met with hostility and censorship, and in some places in the United States, these teachings are still met with the same kind of hostility.
} 
for a sensitive human being emotionally not far removed from the killing of a human being. The experience of resistance and pain, the revolt and the twitching of the warm body, the view of blood and torn-up flesh, the bursting of the inner organs, the imploring cries of pain and of the struggle with death - all that is, just as physical death itself, the same in humans and animals. (qtd. in Beier 157)

\section{Hostility Toward Myths, the War on Nature, Atheism, and the Secularizing Effects of Christianity}

As a result of Christianity's anthropocentrism and radical rationalism and the violent God-image that it creates, "God and religion were seen as radical contrasts to human nature, that is, to the human drives and to the imagery of the human psyche. Already Greek rationality and Hebrew belief in God as absolute over nature went hand in hand with extreme efforts "to overcome the world of myths"' (Beier 157). In doing so, it demonised all mythologies but its own (see Picard 89). However, Drewermann sees it as paradoxical that Christianity, on the one hand, adopted some mythical, archetypal ideals (such as the notion of the God-man found in Mediterranean religions), and on the other, it tried to distance itself from pagan mythology because of this same resemblance. The violent effects of Christianity can be traced to developments in the Early Church's struggle for survival during which time, by historicising and externalising its own reality, it rejected and condemned all other ways of understanding the world (see Beier 158-59).

Because of its historicising of its own mythology, Christianity has always been hostile towards myth. Greco-Roman critics of the Christian religion objected that first, Christianity was itself a mythology - the story of a divine son, conceived by a virgin, performed miracles and preached, died a humiliating death but was then brought to life. And second, they pointed out that Christianity was superstitious by believing that humans 
have a special place in nature (compared to other living things) because of a father in heaven who designed natural laws in favour of humans. In response, Christian apologists tried to prove that there was something new and unique behind the Christian story and that Christian theology contained ideas that had already been extolled by pagan philosophers. The apologists, like the Greek philosophers, argued that myths were just unscientific ways of describing nature and that they contained projections of human longings based on human drives and human desire, and this only idolised nature, materiality and encouraged hedonism. Whereas, Christianity was unique because it provided real freedom for humanity through the death and resurrection of Jesus and clearly showed the relationship between humans and God as something unique since humans were unique in being created in God's image and likeness (see Beier 158). Christian apologists recognised that their stories of Christ resembled some of the pagan myths. They viewed these other myths as distorted images of the truth and as the work of the devil who wanted to mislead humans and they simply "[declared] the other religions to be based simply on fantasy while its own version of the common motifs was defended as historically real, as something that had in Christ actually happened" (Beier 159). Other Christ-like figures in mythology were seen as mere imitations of truth, but the fullness of truth, or the absolute truth, was in Christ. Drewermann notes that this conscious break with pagan mythology revealed itself in the central achievement of Christianity: the discovery of personhood [Personalität], that is, the struggle to distinguish nature and person in humans and God. In Christianity, the entire hope of the collective human psyche is connected with the historical fate of an individual person, with Jesus of Nazareth (159). 
For Drewermann, the discovery of individual personhood "contained in nuce all the cultural values that were later created and formed in the Occident" (qtd. in Beier 160). However, this came at a high price because it contained two extraordinary destructive elements. The first is the attribution of a metaphysically unique position of humans in the world as the centre of creation (anthropocentrism), even in the sense of natural science. This worldview ultimately led Christianity to reject the reason and progressive insights of the natural sciences or to interpret them within its own old worldview (consider the example of Galileo). ${ }^{44}$ Modern science showed that nature does not take a special account of humans, and the idea of a God who created the world "merely according to the needs of purposes of human reason" became untenable. ${ }^{45}$ The second element was the contradictory rejection of pagan myths which "had far-reaching consequences for the way Christianity related to the "irrational" parts of the human psyche, to the unconscious". By demonising the myths of the pagan world (ironically, because of their similarity with the Biblical narrative of Christ), Christian apologists "introduced a deep skepticism against the emotional dispositions of the human soul" (Beier 161).

The world of dreams, of longings, of feelings and sensations should henceforth not serve the search for and acceptance of divine truths - rather they had to be suppressed as something hostile to Christianity, because they were competing with it in the form of myth; only philosophically trained reason and morally practiced will seemed to have prepared for belief in Christ in the pagan world. (qtd. in Beier 161)

Drewermann calls this the "denial of the unconscious in humans" (qtd. in Beier 161). The God-image is removed from the mythological imagery of pagan religion and becomes rooted in history, and concurrently, the realm of the unconscious layers is

\footnotetext{
${ }^{44}$ See Charles Freeman, The Closing of the Western Mind: The Rise of Faith and the Fall of Reason, New York, NY: Vintage Books, 2002.

${ }^{45}$ Drewermann says that the rejection of the anthropocentric worldview in the light of modern science became one of the central reasons for the emergence of modern atheism (Beier 160-61).
} 
disconnected with humanity so that what is really human is associated with consciousness. Christians thus became alienated from the unconscious layer of their psyche which is the source of religious imagery.

The Christian faith sought to ground its imagery, no matter how fantastical (i.e. God becomes human through a virgin birth, performs miracles, is crucified, died, and was buried, is resurrected and ascends into heaven to save us from sin) not in the human psyche but in human reason, and whatever cannot be accepted by reason, people were made to accept as a divine mystery through an act of will (Beier 162). The Enlightenment and modern science, however, would undermine this, by showing that reason could not apply as it was against the principles of natural science. Natural science was able to objectively show that humans were made of the same material as all of nature, and that humans are relatively small and insignificant both in time and space, and in history (when one takes into account the history of the planet, or the history of the universe).

\section{Secularisation of Christian Ideas}

These Christian ideas of anthropocentrism were eventually secularised. Nature was seen as something to be transformed "into a mega-prosthesis, into a sanatorium for a humanity free as much as possible from suffering" (qtd. in Beier 164). The "most basic processes of nature such as death and pain [were turned into] declared enemies of humans. Instead of helping people learn to live with death and suffering, the quest of medical science to overcome or avoid both is done at the expense of virtually any other 'part' of nature" (Beier 165). Religion was reduced to morality in Christianity, and this is 
seen in secularised form today with the tendency to elevate morality to the status of a religion. The "morality of the common good" or a rationally deduced moral law substituted for "God", and the love of God was transformed into the love of humans (Beier 165). As a result, the need for laws outlining a just war arises. ${ }^{46}$

Drewermann argues that while the Hebrew Scriptures contain many passages sanctioning holy war against other peoples, ${ }^{47}$ Christianity attempts to avoid this external violence through a war on the inner nature of humans

it has demonized the unconscious layers of the psyche, the drives and the psychic imagery related to them, and has idealized reason and will. Christianity thus inadvertently created a human type whose pent-up aggression would erupt with explosive power, take reason gone mad with spiritual fear into its services, and thus spread more harm than raw unrepressed aggression could ever have done. It thus created in effect a religion dominated by a rigid superego and a spell of fierce moral perfectionism with all its concomitant hypocrisies and defensive reactionformations. (Beier 167)

All of these are an indication of the need to create more rules for everything, including warfare. For Drewermann, the effects of Christianity on the human psyche create a particular kind of human being whose religious and spiritual needs are, in a way, unmet. Drewermann paints a bleak and lost image of a Christian for whom "[t]he question of what to do was always much more important $[\ldots]$ than the question what kind of human being someone is, which feelings shape him and from which truth he lives" (Beier 182). In part, this leads to increased bellicosity as enemies are easily

\footnotetext{
${ }^{46}$ Drewermann notes that because of the persistent anthropocentrism "humanistic morality centres around humans and perpetuates and even worsens the war against nature because in a world without God the immanent needs of humans becomes infinitized" (Beier 165). This forms the basis of ecological exploitation and over-consumption in today's society (see Beier 166).

47 Some of the passages Drewermann cites include Psalm 144:1; 137:9; 58:9,11; 110:1,6. He cites examples of genocide found in Deuteronomy 20:13-18; Joshua 8:22ff, 10:28, 31; 1 Samuel 15:3.
} 
dehumanised, especially if one believes that one is acting in accordance with divinely inspired rules.

\section{What Does It All Mean?}

This chapter has enumerated a number of factors within Christianity and Christian philosophy that have contributed to the international legal framework for justifying war. In summary, the just war writings of Christian philosophers can be seen to result from the influence of the following metaphysical assumptions and dispositions:

(a) Certainty of belief in Scriptures and a propensity to favour scriptural explanations to scientific ones;

(b) A belief in the fallen nature of man as a consequence of the inheritance of Original Sin, which justifies the rule of the sovereign to maintain order and the ability of the sovereign to wage war;

(c) An undue emphasis on victimhood by arousing empathy for victims which destroys the scapegoating mechanism found in archaic religion resulting in a failure of a society to experience catharsis, thus perpetuating a cycle of violence;

(d) A belief in the historicity of Biblical events rather than an allegorical or mythical interpretation, and the Bible has a violence-of-God tradition, especially in the wars of the Old Testament;

(e) A psychological fear of God;

(f) A radically anthropomorphic image of God which culminates in the idea of the incarnation of God in the form of Jesus; and

(g) General sexual repression and the historical suppression of women (and their ideas) in Christianity.

While all of these factors may not be unique to Christianity, certainly, the doctrine of the Incarnation and the idea of salvation (through the death and resurrection of Jesus) are unique to the Christian experience. What is happening in Christianity, however, is that many of these factors are losing their importance. While more traditional churches may continue to hold onto certain key beliefs, twenty-first century Christianity is in many ways a more tolerant, more benign, more optimistic and more accepting kind of religion. 
And regarding war, while just war thinking may continue to exist in many churches, even within the Catholic Church, there has been much dissent, as indicated in the previous chapter. These factors will be revisited in the final chapter and contrasted with the Hindu worldview. 
Chapter 3 - Sanātana Dharma and War: Examining the Hindu Political Thought on

Warfare

How can the mind take hold of such a country? Generations of invaders have tried, but they remain in exile. The important towns they build are only retreats, their quarrels the malaise of men who cannot find their way home. India knows of their trouble. She knows of the whole world's trouble, to its uttermost depth. She calls "Come" through her hundred mouths, through objects ridiculous and august. But come to what? She has never defined. She is not a promise, only an appeal. (Forster 136)

\section{The Starting Point of Hindu Political Ideas - From the Vedic to the Upanișadic Periods}

This chapter will examine how Hindu political thought has dealt with the ideas of warfare and will contrast it with the development of the just war doctrine in the West. The Hindu belief system directly informs its political theory, and like the belief system, its political theory is also far from uniform. It is also influenced by historic changes and these ideas are often reactionary. For example, the ideas of Kauṭilya's Arthaśāstra (seen as a secular work rather than a work connected with brahmanical influence) or theories of the origin of the king in the Mahābhārata are really a complex blending of ideas rather than a synthesis of older political ideas (Ghoshal vii). Much as in the West, the State was regarded by Hindus as an essential instrument to secure the existence of the people. Social order involved both the horizontal division into orders (áśramas) and the vertical division of classes (varnas). In this division, the kṣatriya householder, under control by 
the king, was expected to protect all other classes. The Mahābhārata describes the duty of the king (räjadharma) as the equivalent of all the moral values connected to the duties of the four classes and four orders put together. The primary law of self-preservation allowed individuals and classes to assume abnormal or emergency duties (äpaddharma) if so needed to protect their livelihood. This included the power to take up arms in selfdefence if the power of the king is compromised or social order is threatened (Ghoshal 6). However, what is universal amongst the various schools of Hindu thought is that both material and spiritual interests of man are considered together, without one taking precedence. This complements the idea that progress towards self-realisation has two components - the path of enjoyment (pavritti) and the path of renunciation (nivritti). Attaining mokșa requires renunciation but under the guidance of enjoyment (and the three ends of dharma, käma and artha) (Ghoshal 7).

\section{The Hindu Practice of War}

The Vedic hymns of the early Indo-Aryans reflect a people who were in constant warfare, most often amongst themselves (Hume 31). Some historians argue that battles in India were extremely bloody. ${ }^{48}$ Others believe that wars in ancient India were merely "Flower Wars" in which "[b]attle was considered to be merely a series of individual combats, with the courage and moral of the mass depending upon the visible performance

\footnotetext{
${ }^{48}$ See Pradeep B. Barua, State at War in South Asia, Lincoln and London, NE: University of Nebraska Press (2005), 8. Note that Barua also says that the Indus Valley civilisation's system of warfare was defensive in nature and relied mostly on fortification. He regards pre-Mauryan warfare as having "stagnant battle techniques" (Barua 8) and that the almost choreographed nature of Indian warfare was due to the philosophy of warfare which emerged in religious and quasi-religious texts (Roy, Ethics of Warfare 26). However, even in the Mauryan period, wars were still limited in nature: even while battles raged on, peasants continued to work their land, and soldiers were strictly instructed not to molest the peasants (Thapar 8-9).
} 
of their leaders. If a leader fell $[\ldots]$ the rest made their escape as best they could" (Heathcote 3). I agree with Kaushik Roy that the truth probably lies somewhere between these extreme viewpoints (Ethics of Warfare 19). However, even a halfway compromise seems on the surface to reflect a lower level of violence in warfare compared with wars in the West.

Unlike in Western philosophy, there is no distinction between jus in bello and jus ad bellum. Hindu writers were not interested in matters of jus ad bellum, especially the principle of right authority, which is so important in Western just war discourse. This is because Hindu thinkers made no distinction between private duels and public violence or between internal and external enemies. One reason for this lack of distinction is that the polities themselves were amorphous structures with fuzzy territorial borders. The power of various kings overlapped and interpenetrated making it difficult to neatly differentiate internal affairs with external ones (see Brekke 59, 61, 80, 113, 115, 119). Roy argues that the lack of distinction was because Hindu philosophers realised that conventional warfare (vigraha) and unconventional warfare/insurgency (kopa) are linked and closely interconnected (Ethics of Warfare 10). Jus in bello rules, however, were important because in the epics, war is the private business of heroes, and heroes cannot be seen to conduct themselves wickedly (Brekke 72-3). Perhaps this is one reason to underplay the existence of any Hindu theory of just war by reference to the epics.

Surya P. Subedi claims that there is no concept in Hinduism of any war against foreigners or against people of other faiths like the Christian concept of "crusade" or "bellum justissimum" or the Islamic concept of "jihad". In other words, there is no idea of a "holy war". This is because, unlike the European religious wars, the kingdoms of 
India were not defined in terms of a loyalty to a single religion, culture or ideology. It was a structure for the maintenance of power and to maintain security against internal and external threats. Unlike the European pre-Enlightenment "states" (or even the Ancient Greek poleis), the kingdoms of India were only to provide stability for, not the structure and basis for the citizens' salvation (Younger 45). Hinduism has always been tolerant of religious and ideological differences, recognising that there are many paths to liberation (moksa). Therefore, wars which aim at spreading the Hindu religion or containing the spread of another religion will be seen as unrighteous wars (adharmayuddha or kutayuddha) ${ }^{49}$ The concept of a "just war" did exist in the idea of dharmayuddha, which was war against the evil characters of the day (national or alien), against unjust action or the denial of rights, and whose aim was the preservation of good, or the maintenance of peace and security (Subedi 343).

Subedi's argument advocates incorporating some of the rules and regulations of the Hindu laws of war into modern international legal documents, such as the Geneva Conventions, to ameliorate current international standards. First, he stresses the pacific elements of Hinduism, as interpreted by Gandhi, stating that it was because of Gandhi's application of the idea of ahims $\bar{a}$ based on his interpretation of Hindu Scriptures that independence was achieved (Subedi 359). Contrast this to the American experience of revolution to achieve independence from the same colonial masters two centuries earlier. He also notes that actual fighting methods specified in Hindu law books and smṛti texts,

\footnotetext{
${ }^{49}$ Subedi characterises the Indo-Pakistan wars following the independence of India as disputes over territory, and not wars of a religious nature. She characterises incidents of communal violence, such as the destruction of the Babari Masjid, where religious reasons for violence were used, as aberrations from Hindu thinking (Subedi 346). Proselytism is practically absent in Hinduism because the idea is that one must be born a Hindu. Note that the terms kutayuddha and dharmayuddha are not strictly equivalent to unjust war and holy/just war because the meaning of these two concepts has changed with time and place (Roy, Ethics of Warfare 11).
} 
would be beneficial to modern international law. Subedi identifies these three rules in particular which could be incorporated into modern international law to ensure that war is conducted in a more humane manner:

1. Fighting should take place only between equals. A country with modern, sophisticated weapons should not attack a country that lacks these weapons; ${ }^{50}$

2. Nuclear weapons and weapons of mass and indiscriminate destruction should be illegal (especially against states who do not possess these weapons);

3. Those without adequate weapons to fight should not be attacked. $(360)^{51}$

He notes that unlike the Western legalists of the seventeenth and eighteenth centuries (who tried to universalise the laws of nations by connecting them with rationalism and stripping these laws of their connection to Christian dogma) law and religion were not separated in Hinduism (and I have already touched on this in Chapter 1). This separation was not necessary because unlike in Christianity, there was no clergy, or no Pope, who wielded a large amount of religious and social authority. Moreover, unlike in Christianity or Islam, the law is not inflexible and static (being based upon single, unchanging religious texts), but owing to the large corpus of religious texts, decentralised nature of the religion, and its diverse schools of thought, there is a built in lack of certainty and precision (Subedi 351-52) which may allow more discretion on the part of the interpreter. Therefore, there is an implication here that when Christian rules became codified into secular law, it resulted in a rigidity in the rules of warfare that

\footnotetext{
${ }^{50} \mathrm{He}$ offers the example of the massive aerial bombing of Afghanistan by Americans in 2001 (Subedi 361).

${ }^{51} \mathrm{He}$ offers the example of the fleeing weaponless Iraqis who were slaughtered in large numbers along the road to Basra by American soldiers in the first Gulf war of 1991. Also, the Iraq war of 2003 when Iraq was disarmed, and bombed after UN weapons inspectors had already stated that weapons of mass destruction were nowhere to be found in the country (Subedi 360). While he admits that humanitarian reasons for a war in Iraq may have been sufficient to launch a war against the country and against the brutal and dictatorial Hussein regime, he argues that the means of fighting were not justified by the Hindu rules of war, although they may have been justifiable under current international standards which make no prohibitions against war with unequals (361).
} 
resulted in a failure of these rules to do what they were developed to do, reducing violence in wars.

\section{Hinduism: War and Peace}

There are many references to war found in the Rg-Veda, and the religious teachings at this time in the development of Hinduism "unquestioningly sanctioned and assisted war" (Hume 33). It was through victory in war that the caste system as an essential religious and social scheme of organisation was established, and this rigid organisational system was tied into religious notions of maintaining order as the universe itself is ordered (for example, the myth of Puruṣa - the Primal Man from whose limbs emerge the various castes). However, the Vedas and the Upanișads had limited influence in the lives of the ordinary Hindus as they were the exclusive property of the Brahmin priests. The texts which have been best known and enjoyed by Hindus have instead been the great epics, the Mahābhārata and the Rāmāyaña, which do not contain any esoteric teachings (apart from the Gītā), but they are martial epics, and many of the Hindu ideas of war come from these epics. ${ }^{52}$ While clemency is praised, the propriety of war itself is not questioned, only the propriety of certain methods of war. For example, the Mahābhārata says: "When the time comes, make peace with a foe; when the time comes, make war against a friend" (qtd. in Hume 39). In the Bhagavad Gītā, which is part of the Mahābhārata, Kṛ̣ṇa encourages Arjuna to fight, to follow his dharma. Thus, the

\footnotetext{
${ }^{52}$ It is my contention that it is perhaps because of the popularity of these epics, and the secrecy and inaccessibility of the Vedic and Upanișadic texts that the imperialistic wars of the Indo-Aryans, which were wars for control of land, for proselytisation (as evidenced by some of the epithets hurled against the nonAryan peoples by the Aryan conquerors) and for cultural domination are overshadowed by the "just" war of dharma that is advocated in the Bhagavad Gitā which is so crucial in the development of the non-violent ideas of those like Gandhi.
} 
existence of war is viewed as a normal part of society (see Hume 44). I will now examine the circumstances that were considered necessary in order to wage war, starting with some of the more straightforward smrti texts (which include the Laws of Manu) that are "relatively fixed in their connotation, and ask you to obey rather than understand" (Mohanty 275). Subsequently, I will move to the more complicated and more multifaceted Bhagavad Gītā, which is considered by many to be a sruti text and as such, has "a plasticity that permits new understanding, [and] the words have a reservoir of meaning, a power of evoking and challenging thought" (Mohanty 275).

The Bhagavad Gītā however is not without contrasts. The teaching of ahims $\bar{a}$, "non-violence" is an integral part of the text, however, both Mahatma Gandhi and his assassin Nathuram Godse drew inspiration from the same Gītā. As will be discussed later, there are some interpretations of the Gîtā that have given rise to a militant political Hinduism in the last two centuries. However, the Gītā is not a war story. The actual battle is only described much later in the Mahābhārata. The violence in the Gìtā is more about conquering the lower self and gaining mastery over our mind and our senses (Rosen 10). The Gītā praises ahims $\bar{a}$ as a quality created by Kṛ̣ṇa (BG 10.4-5), as knowledge opposed to ignorance (BG 13.8-12), as a characteristic of divine nature (BG 16.2-3) and as a desirable austerity of the body (BG 17.14) (Rosen 10). How does this fit in with Kṛ̣ṇa's command to Arjuna to fight? Some see this as the Gītā supporting the idea of fighting in self-defence. Others explain the Gītā as not being about an historical war but about the battle going on in the individual heart.

One of India's greatest Emperors, Aśoka (304-232 BCE) was one of the first political leaders to run his empire on pacifism. Having renounced the violence of his past 
and embracing Buddhist principles, he attempted to unite the various cultural groups in his empire to foster ideological unity. He preached a message of toleration to avoid religious tension between various sects. The various pillars he erected, many of which are still standing today, portray him as a benevolent ruler or paternal benefactor, instructive in good morality, rather than as a conquering military hero as most other rulers might portray themselves. One of his rock edicts tells of his remorse at the death of 100,000 people in a military campaign (the Kalinga campaign) that he himself commanded, and he lamented over the sufferings caused by the war. Still, even Aśoka, though preaching non-violence, did not disband his large army. He did not engage in any more military campaigns after Kalinga, but the army served to deter enemies within and outside of the Mauryan borders. It was to be used as a last option for pacification if persuasion alone failed (Roy, Ethics of Warfare 51). However, the pacific age of Aśoka did not last very long, as the Brahmins saw their higher status being threatened by Aśoka's reforms. The last Mauryan Emperor, Brihadnatha, was killed in $184 \mathrm{BCE}$ by Pusyamitra Sunga, the Brahmin commader-in-chief of the Mauryas and founder of the Sunga Dynasty (Roy, Ethics of Warfare 47-50, 56-57).

Modern India's first prime minister, Jawaharlal Nehru portrayed himself as following Aśoka's principles and wrote: "One here was in India, two thousand years ago, the great Aśoka who, unique among his kind, felt the horror of war in the full tide of conquest and laid bare his heart" (qtd. in Gopal and Iyengar 400). Nehru argued for a defensive strategy, and for world disarmament (Gopal and Iyengar 406-07). This is evident especially in his policies of non-alignment and the wording of the Sino-Indian 
Treaty of 1954 in which the doctrine of Panch Śl̄la - which purportedly finds its basis in the five Buddhist virtues - is applied. This includes the following principles:

1. Mutual respect for the territorial integrity and sovereignty of other states;

2. Non-aggression;

3. Non-interference in the internal affairs of other states;

4. Equality and mutual benefit; and

5. Peaceful co-existence. (Five Principles)

However, modern India is a country with a nuclear program and in recent times the violence of militant Hinduism continues to cause violence and destruction. I will now examine some of the major Hindu political and religious texts in greater detail in order to explain how both these viewpoints can exist and, in Chapter 4, I will show what kind of metaphysical assumptions are responsible for the non-violent ideas of Hinduism.

\section{Kauṭilya's Arthaśāstra and the Mauryan Empire}

The Arthaśāstra of Kautilya ${ }^{53}$ was written during the reign of Chandragupta Maurya (c. 322-298 BCE). It is a compilation of the political thought of the day as Kautilya quotes four specific schools and thirteen individual authors some of whom date three centuries before the time of Kautilya (Ghoshal 70-72). "Artha" is the means of subsistence of men; "śāstra" is the "science of". Arthaśāstra, therefore, is the science which deals with the mode of acquisition and protection of the earth, as Kautilya himself describes in the opening lines of his work. The secondary concept of the Arthaśāstra is

\footnotetext{
${ }^{53}$ Like other Indian classical texts, scholars often debate the dating and authorship of the Arthaśāstra, and some argue that it is a composite product of three of four different authors. Kautilya himself is variously also known as Chanakya and Viśnugupta. He lives during the Mauryan Empire, which was not uniformly administered and partially centralised and partly decentralised, containing several semi-autonomous states within it. The Mauryas maintained a standing army, but also employed many private militias to provide protection to trade and craft guilds from brigands and highwayman as well as to fight internal and external enemies in times of emergency. The name Kautilya is said to be derived from the Sanskrit kutila meaning wicked, shrewd or astute (Roy, Ethics of Warfare 58, 62-63).
} 
dandaniti - "the means of acquiring what is not gained, protecting what is gained, increasing what is protected and bestowing the surplus upon the deserving" (Ghoshal 75). These two concepts are the occupation of the king. Since it is a summary of earlier works, Kauțilya's Arthaśāstra offers an excellent résumé of the art of public administration including a theory of the State (Goshal 77). The State is viewed as a work of art, requiring the exercise of the king's mental and moral qualities for its successful direction (Ghoshal 86). Perhaps the kutayuddha of Kautilya's Arthaśāstra was an attempt to change Aśoka's elaborate code of dharmayuddha (Roy, Ethics of Warfare 56-57). His battle tactics were influenced by the Battle of Hydaspes (326 BCE) - the greatest battle fought in ancient India between King Porus of the Hindu Paurava kingdom and Alexander the Great in which the Macedonian army was victorious (Roy, Ethics of Warfare 80). Kauțilya tried to introduce battle strategies that would prevent future enemy victories. Hence, the Arthaśāstra is chiefly a book about military strategy.

Kautilya opines that when one's duties are fulfilled, it leads to heaven and salvation, but violation of duties brings about mixing of the castes and consequent destruction. He sees the Arthaśāstra as a means for acquiring and preserving both this world and the next, as a source of fulfilment in the life of the individual (Ghoshal 12931). Perhaps as a reaction to Buddhism which focussed mainly on mokșa (liberation, emancipation of the soul), the Arthaśāstra school emphasised materialism over morality. It recognised the four categories of human life as morality (dharma), wealth (artha), desires (kāma) and mokșa - artha being the most important. For Kauțilya, material wealth was prioritised because he saw spiritual well-being and sensual pleasures being dependent on material well-being. Therefore, his advice to the prince is on acquisition of 
material welfare (labha) and its maintenance through good governance and the protection of the people (palana) (Roy, Ethics of Warfare 59, 64).

Roy describes Kauțilya as a realist who believes that the world is full of disorder, chaos and anarchy, and that the only way to have state security is through power. Because of this, he is often compared with Machiavelli. The international system is characterised by the law of the pond (matsanya) in which big fish eat little fish. Therefore, foreign policy should always be shaped by the self-interests of the state. In contrast to the Upanișads and their metaphorical view of violence, Kauțilya presents an instrumental view of organised violence (Roy, Ethics of Warfare 67, 78).

Kauțilya's idea of foreign policy is that expediency should be the golden rule of politics. Making war is to be determined by the strength of the State and the might of its military (Ghoshal 143), in other words, pragmatic rather than spiritual concerns, although the goal towards which the system of statecraft is directed is not territorial aggrandisement (Ghoshal 195). Of course, there are some moral considerations when capturing or conquering territory: Kauțilya cautions against a king coveting land or property of a slain rival rather than trying to install a rightful heir; he should try to eliminate the enemy's vice by doubling his own virtue; he should act in accordance with the will of the people, to favour learned men, orators, the charitable and the brave, to release all prisoners, relieve the miserable, the helpless and the diseased; to respect established customs (unless they are injurious to the revenue or the army or are unrighteous; to adopt the mode of living, dress, language and manners of his subjects and participate in their festivities (Ghoshal 145-47). However, it is not about high morality for Kautilya. When he describes how a prince could act while being kept under restraint, 
or how a king can react to disturbers of the public peace, Kautilya seems to show an indifference to morality, although his "immoral statecraft" seems to be reserved for extreme situations. Whether or not he is indifferent to religion is harder to answer. In some places, he dissociates himself from the school that eliminated the Vedas from the list of sciences, and he urges the king to maintain the hierarchy of castes and orders. In some places, he tries to use religion as an instrument of state policy, or to politically exploit religion, for example when replenishing the state treasury. This gives the impression that perhaps religion had no place in politics for Kautilya (Ghoshal 151). His Arthaśāstra, however, was incorporated into the brahmanical canon, which influenced how the duties of the king are described in the Mahābhārata and the Laws of Manu (Ghoshal 157).

For Kautilya, the principle danger that the state faces arises from prakrti kopathe anger of the people when they lose faith in the established government. Therefore, he advises the ruler to control his senses in order to direct the administration of the state vigorously and to endear himself to the people and not become a tyrant. Force must not be used indiscriminately. He advises a king to first indulge in mantrayuddha (a battle of wits and diplomatic manoeuvring backed by force) before resorting to force. $\mathrm{He}$ introduces the idea of yana - coercive deterrence aimed at the enemy state through a display of military strength and bravery. He also encourages the use of envoys and spies to infiltrate the enemy and use trickery to obtain victory, including the use of biological warfare (poisoning enemy wells and food supplies) (Roy, Ethics of Warfare 73, 75, 9192, 100). Therefore, Kauțilya adopts kutayuddha, or waging war through duplicity, treachery, and trickery (Roy "Just and Unjust War" 236). Kautilya defines 
dharmayuddha as prakasayuddha - open or regular warfare, and this warfare was considered righteous, similar to the battles of the Greek hoplites or European codes of chivalry before the Middle Ages. However, he says that reliance on kutayuddha may be warranted in a situation when the monarch is unsure of victory or unsure whether his forces are stronger than that of his enemy's. In reality, wars are rarely straightforward, therefore, kutayuddha may have had to be employed (Roy "Just and Unjust War" 236). ${ }^{54}$ John W. Spellman notes that it is perhaps because of their high idealism that the just war regulations were often disregarded in practice and rarely all applied in combat, although some of these rules were enforced. However, regardless of their application, the very existence of these rules in the religious law-books "shows a very humane and ethical standard which ideally, at any rate, surpasses that of modern times” (Spellman 161).

However, Kautilya, rather than forming continuity with the Hindu tradition represents a break with it. He differs from the position of the Bhagavad Gītā in which the purpose of war was existential (Roy, Ethics of Warfare 78). He makes a distinction between religion or morality and politics. He advises the king to do many immoral things in the interest of the State, but does not advocate immorality for personal gain, and

\footnotetext{
${ }^{54}$ Kutayuddha was also employed by Aryans against non-Aryans and the laws of dharmayuddha were seen only to apply to inter-Aryan wars. The wars of the Mahābhārata are inter-Aryan wars, and hence any ideas of just war that derive from the Mahābhārata may only be applicable to fighting between Aryans. However, even in the Rāmāyaṇa, which represents wars between Aryans and non-Aryans, there are constraints on military ethics (see Roy (2012) 34). The specificity of just war only applying to fighting those like you was also applicable to the Christian just war doctrine, however. In the West, this idea was abandoned in favour of trying to establish a universal norm. In the same way, this study attempts to do the same for Hindu ideas. Note, however, that even Kṛ̣na himself resorts to kutayuddha arguing that sometimes, the ends justify the means, and since the Pāṇava's cause was just, there is no immorality (aniti) involved if a minimum of adharma were used. So, for example, Kṛ̣na relies on trickery to tell Drona that his son Aswathama had been killed so that he would be disheartened and give up fighting, at which time, he advised Arjuna to kill Drona. Kṛnna also advises Arjuna to kill a disarmed Karna who had left his weapon to free his chariot from the mud. It was considered unethical to take advantage of an unarmed enemy. Kṛṣna also advised Bhīma to strike Duryodhana on the thigh with his mace (gada) although the rules of mace warfare prescribed that an opponent could not be struck below the navel (see V.M. Mohanraj, The Warrior and the Charioteer: A Materialist Interpretation of the Bhagavad Gita, New Delhi: Left Word, 2005).
} 
counsels the king to act with virtue and self-restraint. He even recommended recruiting soldiers from all four classes to prevent any one community from becoming too powerful in the state. This is yet another indication that while Kautilya saw the usefulness of the Vedas in establishing the four classes, and the four orders in their respective duties, he was willing to break with the tradition if he thought it would best serve the interests of the state (Roy, Ethics of Warfare 83). Kautilya's writings are a product of their time and address the king of a country whose security was constantly being threatened, internally due to maladministration, and externally by the threat of invasion from adjoining regions and also Greek invasion (Appadorai 24-25). It is because Kauṭilya is seen as breaking with tradition that perhaps requires that his importance when discerning Hindu ideas of warfare be downplayed.

\section{The End of the Mauryan Empire and the Laws of Manu}

Following the fragmentation of the Mauryan Empire, the sütra literature began to emerge. These were aphoristic manuals which dealt with religious matters but also the duties of the king and civil, criminal, and military law (Roy, Ethics of Warfare 110). The Manusmṛti (popularly referred to as the Laws of Manu) is based on the lost Dharmasūtra work of the school of Manu, but unlike the school of Manu, this is not a product of a Vedic school but of one of the special law schools which were developed. Manu was probably not the real name of the author (or authors) of this work, however the work itself is seen as the brahmanical response to the rise of Buddhism and Jainism. ${ }^{55}$ The

\footnotetext{
${ }^{55}$ Roy notes that the Nanda and Mauryan dynasties were both founded by Śudras, whereas the Sunga and Kanva dynasties that succeeded them were founded by Brahmins, and the Laws of Manu were developed as a guide to these Brahmin dynasties to ward off any threat of domination of the two upper castes by the Sudras (Roy, Ethics of Warfare 110-11).
} 
Manusmrti is unconnected to any school although it is considered a work on the sacred law (smrti). However, regarding politics, these texts seem to offer more information about the duties of kings (räjadharma), and the origin of kingship than specifically dealing with the question of war or the use of war as a means of statecraft (Ghoshal 192). In contrast to Kautilya, the Laws of Manu seem to portray a return to the prioritising of dharma over artha and kāma and a turning to the Vedas as the highest and ultimate source of all knowledge (Roy, Ethics of Warfare 111).

The Dharmasūtra texts present a concept of social order as the division of society into a number of parts (the four varnas and the four āśramas) each of which is subject to certain rules. The source of these rules is said to lie in the will of the Supreme Being. "It therefore follows that Society, as here conceived, is the rule of Law, the Law being held to be imposed from without by the Divine will" (Goshal 59). These divisions were meant to reflect the principle of specialisation and division of labour:

(a) the Brāhmanas (Brahmins) to study, teach, sacrifice for themselves and others and protect the Vedas;

(b) the Ksatriyas to study, sacrifice, use weapons, protect treasure and life of created beings for the growth of good government;

(c) the Vaiśyas - to study, sacrifice, cultivate the soil, trade, tend cattle, for the growth of productive labour; and

(d) the Śüdras - to serve the three higher castes.

The Ksatriyas ${ }^{56}$ have a special function - that of protection - and the king is the Kșatriya par excellence. One aspect of the kșatriya dharma is the notion that the warrior is expected to offer protection and be for the overall benefit of the people, as stated by the sage Parasara: the kșatriya's duty is to protect the citizens from all kinds of difficulties,

\footnotetext{
${ }^{56}$ Note that soldiering in the Vedic age was confined to those born into the kșatriya caste, thus automatically excluding many people from fighting. In contrast, in Western philosophical traditions, the entire citizen body were capable and in some cases liable for military service (e.g. in the Athenian polis, all citizens between the ages of eighteen and sixty had to perform military service) (Ridley 156). This idea of military service for all continues in many Western countries today.
} 
and for that reason he has to apply violence in suitable cases for law and order. Therefore, he has to conquer the soldiers of inimical kings, and thus, with religious principles, he should rule over the world (Subedi 345). Even the word ksatriya is derived from kșat meaning "hurt" and trayate meaning "to give protection", therefore, a kșatriya is one who protects from harm (Rosen 19). The idea that the quality of a man's conduct is also determinative of the ultimate fate of man is also one that is seen in the Gitā. Intention in action is important - intention is supposed to be in service of the divine and for no other reason - that is, action should be motiveless. ${ }^{57}$ The ancient Upanișads describe the kșatriya as a kind of gardener, pulling out weeds that threaten the healthy growth of the garden (see Prabhupāda 37).

The king also has the duties of punishment, providing State relief to the Brahmins, fighting the enemy, levying taxes, administering justice, appointing State officers, and performing sacrifices. This king is governed by a whole series of rules in the Dharmasūtras, but in many ways, the king is described just like another civil servant a magistrate, paid to protect his subjects (Goshal 65). The king is there to enforce the laws of the Brahmins and therefore, to increase the virtue of his subjects. There is also

\footnotetext{
57 The Gītā says: "If even a man whose conduct is most evil devotes himself to me and none other, he should be considered good, for his intention is right. Very soon will he become righteous in soul (dharmātma ) and gain [thereby] eternal peace" (BG 9.30-31 qtd. in Zaehner 96). Virtue is also important for "all those whose evil deeds have come to an end and whose actions are good are released from the delusion of the opposites and participate in me [God], firm in their resolve (RV 7.28)" (Zaehner 96). The Rg-Veda also has the idea of salvation through grace and virtue, and faith in any deity is considered directed to the true God, and will obtain God's grace (see RV 7.21). Similarly, the good works of a person can be considered part of his devotion to God (see 12.13-20). For Zaehner, the last verses in the Rg-Veda seem to reflect a turning point in Hindu history from a strict emphasis on performing the duties imposed by the dharma of one's caste to instead, devoting one's self to God, so as to obtain the grace of God, and thus achieve liberation (98). Zaehner does note that the concept of 'sin' as an offence against God is a Christian concept that had no bearing on Hindu thought until India's contact with the Christian West in the last two hundred years (138). Note that the verse cited in the Gita with the phrase "rule over the world" may imply some kind of universality to the duty of the ksatriya, however, it seems that "world" might be a metaphor because Hinduism tends to focus solely on the life of Hindus. One must be born a Hindu, and leaving the subcontinent results in loss of caste.
} 
the idea that an unrighteous king is the cause of disturbance of the social, the moral and even the physical order (Ghoshal 99). Ghoshal however describes that the Arthaśāstra schools that developed alongside the Dharmasūtras produced many works which contributed to the development of Hindu political theory, unfortunately, he states that the Dharmasutra's "present condition, however, is no index of its true character. For the whole of it has perished with the exception of a few fragments that are scattered through the pages of the later brahmanical canon as well as the secular Arthaśāstra [of Kauṭilya] which is independent of sacred canon and the product of secular schools and individual teachers" $(68,81)$. The Vedic texts describe the caste system as one which does not only take into account birth, but also a person's individual nature. The caste system, was therefore, originally more fluid, allowing movement between castes. One reason for this is because natural inclinations must be allowed to flourish and forcing one's offspring to continue to do one's duty even if one's offspring is not suited to was not seen as practical (Rosen 19). The varna system was meant to be a form of yoga. It was a type of sacrifice or yajña, an opportunity to serve God in the way most appropriate to the individual.

With the onset of Buddhism, which in turn influenced the Hindu religion from which it sprang, deeper questions are asked about the role of mankind in nature. Rather than focussing merely on the sovereignty of the divine, Buddhist scholars tried to trace the origin of human kinship to its roots in a hypothetical State of Nature. This also introduces the idea of questioning the origins of social and political order and the hierarchy of the social order (Ghoshal 117). The Laws of Manu describe the role of the king as being for the protection of creation: "For when these creatures being without a king dispersed in all directions, the Lord created a king for the protection of this whole 
(creation), taking (for that purpose) eternal particles of Indra, of the Wind, of Yama, of the Sun, of Fire, of Varuna, of the Moon, and of the Lord of Wealth (Kubera)" (qtd. in Ghoshal 173). This passage begins referencing an original evil state of nature of mankind and the king is created directly by the will of God to rule over his subjects.

In the Mahābhārata, there are two theories about the origin of kingship. The shorter account (told by Bhīṣma) is that God appointed a king to rule over the people to prevent the people from fighting each other because without a king, society seemed to be heading towards the path of chaos and anarchy (see Ghoshal 175). This is almost like the warlike state of nature described in Hobbes' Leviathan. The second account describes a peaceful state of nature that became corrupted because of the vices of man. And thus, a king was created by God to occupy the highest place (śraisthyam) amongst mortals. The duty of the king, in both cases, is to protect the people and to punish evildoers with force (dandaniti) (Ghoshal 177). In both accounts, the king's creation is attributed to the will of God. In the first account, the people seem to make a one-sided contract with the kingdesignate, relieving him from the responsibility of their own sins and committing themselves to paying royal dues. Thus, the king rules by right of divine creation reinforced by the voluntary agreement of his subjects. In the second account, the king has to accept an oath (pratigya $)$, but at this time he is mentioned as being ordained by Viṣnu and animated by His essence. Therefore, the notion of the king's divine nature is the basis of both views, thus strengthening the principle of authority between ruler and ruled by the authors leading up to the start of the Common Era (see Ghoshal 180). There is always a requirement for the King to act virtuously. In the Śāntiparvan, Bhīṣma instructs Yudhișthira that the primary duty of the king is to first conquer his own self and 
afterwards conquer his enemies. The king is enjoined to give up covetousness and anger and to not be swayed by the influence of desire (Ghoshal 191).

Manu was definitely no pacifist. He enumerates certain duties of the king during battle: to organise troops and battle formations; to inspect troops and motivate them to fight; and, to monitor their behaviour when engaged in combat. He states that war is the eternal law of the king: "yodha dharma sanatanah". Like Kauțilya, he advises a king to expand his influence, or at best, to maintain his kingdom, to keep his troops ready for battle and to constantly display military might and probe the weaknesses of enemies. (Roy, Ethics of Warfare 113). However, he criticises the kutayuddha of Kauțilya, saying that a king should always act without guile. He believes in upholding alliances and treaties where Kautilya would have broken them if necessary to secure the interests of the state. He sets out a model for fighting (jus in bello laws), prakasayuddha which is part of dharmayuddha. For example, there is a prohibition of the use of the deadly weapons, the Brahmāstra $^{58}$ and the Pāśupatāstra, ${ }^{59}$ (what we in modern parlance would refer to as weapons of mass and indiscriminate destruction) against one's enemies unless they used weapons similar to these. Use of these weapons would render a war as kutayuddha, and soldiers engaged in these activities were to be punished (Subedi 356).

\footnotetext{
${ }^{58}$ In ancient Sanskrit mythology, a Brahmāstra is a weapon created by Brahmā (āstra means 'missile weapon'). As described in a number of the Purānas, it is considered the deadliest weapon. It is said that when a Brahmāstra is discharged, there is neither a counter attack nor a defence that may stop it. It is believed that the Brahmāstra never misses its mark and must be used with very specific intent against an individual enemy or army, as the target will face complete annihilation. The weapon also causes severe environmental damage. The land where the weapon is used becomes barren for eons and all life in and around that area ceases to exist. Women and men become infertile. There is severe decrease in rainfall and the land develops cracks like in a drought (http://en.wikipedia.org/wiki/Brahmastra).

${ }^{59}$ The Pāśspatāstra, in Hindu mythology, is the irresistible and most destructive personal weapon of Śiva discharged by the mind, the eyes, words, or a bow. Never to be used against lesser enemies or by lesser warriors, the Pāśspatāstra is capable of destroying creation and vanquishing all beings

(http://en.wikipedia.org/wiki/Pashupatastra).
} 
There are also jus in bello laws to ensure humane conduct when a battle is underway. The Laws of Manu in a chapter entitled "On Government; or, On the Military Class" state the following prohibitions:

1. Concealed weapons, arrows "mischievously barbed", poisoned arrows and flaming darts are not to be used;

2. Fighting should be between equally equipped soldiers, e.g. a charioteer can only attack another chariot and not a man on horseback or on foot;

3. Weak, effeminate, wounded or tired men, terrified men, men whose vision is obstructed by loose hair, or men retreating or surrendering should not be killed;

4. Men who are asleep, or who have lost their armour, weapons, chariot or who have damaged their armour or weapons should not be attacked; and

5. Non-combatants should not be attacked. (See Laws of Manu, ślokas 90-93 and 98 qtd. in Subedi 355)

Some of these rules are also influenced from injunctions found in the Mahābhārata:

1. Fighting should be on a one-to-one basis and should cease when the opponent becomes disabled;

2. A man who has no son should not be killed;

3. A King should only fight with a King;

4. One who surrenders must not be killed but be captured as a prisoner of war, and must be treated humanely;

5. Anyone leaving the field or sitting in Yoga posture was immune from attack;

6. Aged men, women and children, non-combatants and those hiding in fear should not be killed;

7. The panic-stricken and retreating should be pursued and attacked;

8. Animals were not to be killed unnecessarily or deliberately;

9. Peaceful bystanders, the insane, one who is eating, a camp-follower, a war musician and the guards at the gates should not be killed;

10. Gardens, and places of public worship should not be disturbed;

11. A wounded prisoner should be sent home or should have his wounds treated;

12. When a fort is captured, it should not be set on fire, for this will cause indiscriminate damage; and

13. Fighting should not take place at night. (K.R.R. Sastry, 'Hinduism and International Law' 117 Receuil des Cours (1966-1) and Winthrop Sargeant, trans., The Bhagavad Gita 27 qtd. in Subedi 355) 


\section{The Hindu jus ad bellum}

The Laws of Manu also contain certain ad bellum recommendations, or four techniques (caturopāyas) of dispute resolution which are to be attempted before military force is used:

When he [a king] thus had prepared himself for conquest, let him reduce all opposers to submission by negotiation (sāma or conciliation, pacification) and three other expedients, namely, presents (dāna), division (bheda which is dissension or veiled threat), and force of arms (danda): If they cannot be restrained by the three first methods, then let him, firmly but gradually, bring them to subjection by military force. (qtd. in Subedi $352)^{60}$

Therefore, war is to be only used as a measure of last resort against evil, and as a defence of rtaldharma. Hence, there is no Hindu justification for aggression, and only defensive wars are permitted (Subedi 348). There are some examples of using caturopāyas in the Bhāgavata Purāṇa. Kṛ̣ṇa's father and Arjuna's uncle Vasudeva use it to pacify the demonic king Kamsa (10.1.37-46). Before a war can be waged, the King was obliged to inform his enemy of the intention to go to war, and the enemy party was to be given sufficient time to prepare itself for war, or for alternative courses of action, such as surrender (Subedi 353-54). Before fighting was commenced, a declaration of war had to be made, even when on the battlefield. For example, even in the Battle of Kurukșetra (which will be discussed, Arjuna sounded the conch, and the Pāṇdavas and

\footnotetext{
${ }^{60}$ Although, Subedi notes that in ancient India, the ultimate glory for an egocentric and ambitious Hindu king was to become the imperial king by subjugating neighbouring chieftains and other rulers (352). However, once these neighbouring areas were controlled, in return for their allegiance, the emperor owed his conquered subjects, and even their king, a benevolent duty of protection and these subjected peoples were to be allowed to live in peace with full autonomy over their domestic affairs, and even autonomy regarding their defence and foreign policy within the empire (353). Subedi also notes that there are many instances when the laws of war were not followed, even by the gods such as Hanuman (who started a fire in Lanka in the Rāmāyaṇa), or Kṛ̣ṇa and Arjuna (who resort to dubious methods of warfare to defeat the enemy in the Mahābhārata) and even Yudhișțira who resorts to lying which results in the death of Drona. However, he notes that these violations of the rules of war do not appear to diminish the significance of such laws (357; see also Rosen 24).
} 
Karauvas did the same to signal the start of the battle. Kautilya further states that to be in strict accordance with dharma, the place and time of the battle must be specified beforehand (Arthaśāstra 13.5.3-15).

\section{Jus post bellum}

There are also jus post bellum ${ }^{61}$ laws specified in Hindu literature, something that the Christian just war doctrine does not address in such detail. These are described in the Laws of Manu and the Arthaśāstra (see 10.3.26 and 7.16.26, 27) and can be summarised as follows:

1. The religion, deities and clergy of the conquered peoples are to be respected, and the gods of the territory are to be shown devotion;

2. Largesse should be bestowed upon the conquered peoples;

3. After the conduct and intentions of the vanquished are ascertained, a prince of the royal race of that conquered country must be established in the country and be given specific instructions, and be allowed to establish laws to run that country;

4. The prince of the conquered peoples ought to be gratified with jewellery and precious gifts;

5. The conqueror shall substitute his virtues for the defeated enemy's vices and where the enemy was good, he shall be twice as good, and beneficial to the constituents by acting according to his dharma and by granting favours and tax exemptions, giving gifts and bestowing honours;

6. The way of life, dress, language and customs of the conquered people should be adopted by the conquerors;

7. The conqueror should participate in the festivals and amusements of the conquered people;

8. The chiefs and leaders of the conquered peoples are to be pleased;

9. The ill, the helpless and the distressed are to be aided;

10. The slaughter of animals shall be prohibited on specified days;

11. "The conqueror shall not covet the slain king's land, wealth, sons or wives but give the members of the family their appropriate positions". (qtd. in Subedi 356)

\footnotetext{
${ }^{61}$ In Western just war discourse, jus post bellum concerns are a relatively late development: see Brian Orend, "Jus Post Bellum," Journal of Social Philosophy 31, no. 1 (Spring 2000): 117-37; or Gary J. Bass, "Jus Post Bellum," Philosophy and Public Affairs 32, no. 3 (October 2004): 384-412.
} 
However, can merely referring to the Laws of Manu provide a Hindu just war theory? The Laws of Manu are more recent than the śruti texts, and were not followed by the majority of Hindus in their history. It was popularised only in the eighteenth century when British scholarship discovered and translated the text. Many of its edicts towards women or low castes are viewed with strong disfavour. Finally, Manu's model of conducting dharmayuddha may have reduced the combat efficiency of the Hindu armies in fighting external invaders (see Roy, Ethics of Warfare 121). I do not think that an examination of smrti texts alone is conducive to an understanding of the Hindu philosophy regarding war, since the basis of Hindu philosophy lies in the teachings found in the śruti texts. Therefore, the question of a Hindu theory of just war will be further examined in the next chapter by looking at the Bhagavad Gìtā, which dominates Hindu thinking and forms the basis for Hindu ethical positions. However, now, I will continue with the examination of Hindu political works. Many of these seem to draw inspiration from the works that preceded them, and constantly reflect a tension between dharmayuddha and kutayuddha

\section{War and Violence as an Instrument of the State: Hindu Political Works After the Common Era}

Another important secular text of the Hindu political literature is the Nitisāra of Kāmandaka (sixth century CE) - written in the style of the Arthaśāstra, in which the author conducts a study on the phenomena of the State. Kāmandaka explains that his work is based on Kauțilya's, but he is also influenced by the brahminical canon. Kāmandaka describes the seven limbs of the monarchy: the king, ministers, kingdom, 
castle, treasury, army, and allies, which are to be fuelled by good sense and unebbing energy (see Singh 12, Ghoshal 214-16). Each of the limbs is viewed as being helpful to the other, and without one of which, sovereignty fails. He reproduces the ideas of kingship of the older thinkers by saying that the most important thing the king provides is protection to his subjects. In his views on the role of punishment (danda), one can infer Kāmandaka's view of the nature of man - that society is doomed to anarchy unless they have a king to dole out punishment (Ghoshal 219-20). He does say that the king has the duty to act virtuously and to be devoted to righteousness, but he reproduces many of the rules in the Arthaśāstra, for example, advising the king to slay without delay those who disturb the public peace. Regarding fighting, Kāmandaka divides it into two kinds - fair and treacherous. The former should be resorted to when the king has the advantage of time and place and is powerful, whereas the latter can be used in contrary circumstances, and includes attacking the enemy on unfavourable ground or when he is off his guard. The idea of slaying for the preservation of the public peace is very evident in Kāmandaka's work: "Kings that were almost like sages had recourse to righteous slaughter; hence the king is not afflicted with sin by slaying the wicked in the interests of righteousness" (qtd. in Ghoshal 222). Relating to unrighteous fighting, Kāmandaka says that slaying of the foe by treachery does not obstruct righteousness and he cites the example of the Kuru hero Aśvatthāmā who slew the Pāṇḍava host during the night when he was sleeping. Thus, Kāmandaka harkens back to Kauṭilya and unlike Manu, is willing to include elements of kutayuddha in warfare. There is tension in the Nītisāra regarding the proper ethical limits of conducting a war. Unlike Kauṭilya, Kāmandaka is not willing to go as far in advocating kutayuddha (Roy, Ethics of Warfare 144). 
The second class of writings dealing with the state and the role of the king are the Purānas and the minor law books (smṛti) which represents the literature of the brahmanical canon. Most of these books merely contain an "endless and monotonous repetition of the rules of kingly conduct in the place of speculations of an abstract nature" (Ghoshal 223). These texts do not seem to elaborate further on the question of war or on the morality of war.

The final series of political texts are the commentaries of the two smrti treatises of Manu and Yājñavalkya, the main commentators being Medhātithi, Vijñāneśvara and Aparārka. Medhātithi further elaborates the concepts of rājadharma and daṇ̣̂nitit. Previous authorities, like the Sanntiparvan declared that some branches of rājadharma are based not on the Vedas but upon reason and experience, but yet, the association of rājadharma with the doctrine of varnāśramadharma suggests a Vedic continuity of thought since the Vedas are the primary source of the dharma. The Śāntiparvan declares that the science of dandanit i was created by Brahmā. For Manu, dandanīti is described as "eternal" (śáśvatī) which is a term usually reserved for the Vedas (Ghoshal 233).

However, Medhātithi comments that all duties do not have their source in the Vedas, but that reason and experience have a part to play in ascribing duties. Previous authorities observed that the doctrine of varnāśramadharma meant that only the kșatriya had the duty to protect the people (of all classes), hence, Manu describes the king's duties as those belonging to an individual kșatriya. But Medhātithi enlarges the idea of kingship beyond the kṣatriya (Ghoshal 234). Vijñāneśvara further expands the conception of the king's duties beyond the kșatriya order, expanding the idea that the duty to protect extends to individuals other than the king. Therefore, non-kșatriyas could 
rightly fight when protecting others - a right of humanitarian intervention (see Ghoshal 234). Aparārka agrees with this reasoning and in his commentary on Yaajñavalkya he enjoins non-kșatriyas who perform the duties of kșatriyas to perform all the duties of the kșatriyas. This is tied to the receipt of taxes: "[O]ffering of taxes has no other reason than self-protection. Therefore it is proved that he who takes the taxes is bound to protect the people." This connection between protection and taxes can be traced to the Dharmasūtras, however, Medhātithi makes it clear that it is not only those who pay taxes who are to be protected, but also the poor and the friendless (Ghoshal 236-239).

Regarding the duties of the king's subjects, looking at how the rights of the subjects are defined may offer some insight for the role of warfare in protection of the people and punishment of the guilty (the two essential kingly duties). Manu said:

Twice-born men may take up arms when (they are) hindered (in the fulfilment of) their duties, when destruction (threatens) the twice-born castes (varna) in (evil) times, in their own defence, in a strife for the fees of officiating priests, and in order to protect women and Brāhmanas; he who (under such circumstances) kills in the cause of right, commits no sin. (qtd. in Ghoshal 240)

Medhātithi elaborates

When a king is neglected and destruction ensues, recourse should be taken to arms. At other times, however, when the kingdom is well-governed, this king himself protects his people. [...] The king cannot stretch his arms to reach every individual. There are some wicked persons who obstruct even the royal officers (that are) very valorous and intent upon (the discharge of) their duties. But one always fears a person wielding weapons. Hence using weapons on all occasions is justified.[...] On such occasions recourse should be taken to arms for protecting one's own wealth and relations. According to others the interests of other people also (should be served) in such times. (qtd. in Ghoshal 241) 
Thus, Medhātithi extends the right of bearing arms to all subjects, even in normal times, and for the purpose of self-defence as well as for the protection of others. This is based on the argument of insufficiency of state administration as well as self-reliance. There is a right of rebellion of the subjects as well, where rebellion is justified if it is based on the "will to sovereignty" but not if based on the lust of power. It is based on maintenance of the public good and justified by the inability of an incompetent ruler to serve the interests of his subjects (Ghoshal 242).

The Hindu political texts before the Muslim invasion in the twelfth century remain today the bulk of Hindu thought, and, at least from a perspective of examining warfare, no major political treatises seem to emerge after the invasion. There is still a constant tension between dharmayuddha and kutayuddha. There are some similarities between the concept of dharmayuddha and Augustine's just war: both regard war as a last option, and both accept that the use of coercive force is an essential component of political authority of the ruler. However, in the Augustinian framework, a just war could be initiated by a legitimate ruler or by the command of God. In dharmayuddha, a just war is initiated for a just reason by a just ruler, but never by the command of God. Generally, dharmayuddha was thought to be a defensive war and never offensive and was geared towards establishing a hegemony (a cultural sphere of influence) rather than complete territorial control. Indian polities, compared to the Empires of Rome or China tended to be less militaristic. Empires (with the exception perhaps of the Gupta Empire) tended to be more hegemonic than territorial and contained numerous semi-autonomous tribes and agrarian communities. Christian just war theories did conceive of a just war as a holy war, and the Church allowed forcible baptism of unbelievers, and these led to the 
territorial expansion of Empire. However, this idea was absent in Hindu political thought and even after the Muslims invaded, wars for conversion of religion were never launched (Roy, Ethics of Warfare 158-159, 184). ${ }^{62}$ Distinctions between dharmayuddha and kutayuddha continued to be made by developing more jus in bello prescriptions which detailed which weapons or which animals could be used. However, during the period of the Moghul conquest, it was more politics than religion which determined both how Muslim and Hindu rulers acted. After the twelfth century, the Arthaśāstra had fallen into obscurity, however, the Bhagavad Gītā started to become the pre-eminent text (Kapila 442). This is another reason to downplay the importance of the Arthaśāstra in a Hindu theory of just war.

\section{Hindu Political Theory after the Islamic Invasion}

In the eleventh and twelfth centuries CE, Northern India was conquered by the Muslims. During this time, the Śukranīti (also titled the Nìtiśastra - the science of the rules of polity $(n \bar{i} t i))$ and the commentary of Mādhavāchārya were written when the largest provinces of India had fallen to the Muslim conquerors. These authors attempt at maintaining a continuity of thought with their philosophical predecessors. The Sukranīti is described by Ghoshal as "the last notable monument of the Hindu genius of political speculation" (Ghoshal 248). It greatly relies on old literature on polity but also shows originality of thought in certain aspects of political theory. It is attributed to the ancient

\footnotetext{
${ }^{62}$ See also Gregory M. Reichberg, 'Norms of War in Roman Catholic Christianity', in Popovski, Reichberg and Turner (eds.), World Religions and Norms of War, 154-6. Note that the Sukraniti did imply that kutayuddha could be practised against the Muslims when defending Hindu homeland (Roy, Ethics of Warfare 190), however, this does not seem to be an attack on Muslims qua Muslims but rather because of their status as invaders. It reflects the constant tension between dharmayuddha and kutayuddha and the fact that the meanings of these terms sometimes became reversed.
} 
guru Śukrāchārya $(16,050-15,330 \mathrm{BCE})$, but is thought to have been written in late mediaeval period. The Śukranīti describes politics not as an independent branch of study, but part of the science of general morals. It is mainly aimed at the king, whose primary functions of protecting subjects and chastising the wicked continue to be emphasised, and the Śukranīti itself is a handbook for royal behaviour and a guide to successful administration. The science of polity is viewed as the source of livelihood of all creatures and the way in which the established usage of men (i.e. the social order) is maintained; thus the author seems to elevate the science of government above the other sciences saying that $n \bar{t} t i$ is as essential for the maintenance of the established usage of men as food is essential for the maintenance of the established usage of the body. Unlike the other science, nìti fulfils the interests of all people, and thus other sciences like Grammar, Logic and even Vedānta have no importance and no bearing on the ordinary affairs of men.

The Śukranīti compares the seven limbs of sovereignty with the organs of living beings. Its author writes: "Among these the king is declared to be the head, the minister (is) the eye, the ally the ear, the treasury the mouth, the army the mind, while the fort and the territory are the two arms and legs" (qtd. in Ghoshal 252). By using such an organic analogy, the author seems to emphasise the notion of co-ordination of these different elements to a common end: "The people do not follow their respective duties without the king's protection; on the other hand, the king does not prosper on earth without the people" (qtd. in Ghoshal 253). This upholds previous thinking that the king is responsible for protection. As the Śukranīti states: "The gods kill and cast down the king 
who does not afford protection, the Brāhmaṇa who does not practise austerities and the rich man who does not give alms" (qtd. in Ghoshal 257).

The Śukranīti justifies the king's authority to rule over his subjects by reference to the doctrine of karma: "Karma alone gives rise to good and bad conditions on this earth; the deeds done in a previous birth (prāktana) are themselves nothing without karma; who can even for an instant exist without karma" (qtd. in Ghoshal 254). The division of castes is explained by quality and merit of the deeds done in the previous birth, and it is in accordance with such deeds that everything happens. Therefore, the king's right to rule is derived from the merit of the sum total of his deeds in his previous birth. This harkens back to the idea of the divine right of kings of earlier thinkers (Ghoshal 255).

The final Hindu political text to be considered is the commentary of the scholar Mādhava on the smṛti work of Parāsara. Mādhava conceives of the king as a divine incarnation, and this belief is tied to the king's prime duty of protection: "As the divine incarnation in the form of Rāma and others came into existence for punishing the mighty Rāvana and others like him, so the divine incarnation in the form of the king (rājāvatāra) is born for the purpose of punishing lowly beings like thieves and the rest" (qtd. in Ghoshal 260). Regarding the rights and duties pertaining to the kșatriya ruler, unlike the thinkers before him who held that those duties belonged to all rulers of kingdoms and even subordinate executives, Mādhava says that only the king has the right to punish, and moreover, the king had to be a kșatriya.

After the seventeenth century, some think that political thought in India died. This was due to several reasons: first, Sanskrit declined as the language of the learned; and, second, India had reached a "civilizational equilibrium" where there were few 
religious wars, compared to the religiously-motivated conflicts in Europe at that time (Kapila 442).

\section{Christian Influences on Hinduism}

The Mughal Empire was replaced by the British colonial power in India. During this time, in the two centuries before 1947, Indian history is considered to be a break with the past since the British-Indian Empire was a secular political entity (and perhaps Modern India is a reflection of that break). The British did, however, use the various religions in India in order to establish their control and to construct a loyal army (Roy, Ethics of Warfare 211).

The British reign can be thought of in three stages. The first, in the eighteenth century, began with interest in scholarship following the discovery of the Indo-European language system, and it culminated in 1813 when the British government took over Indian administration. During this stage, the British did not seek to interfere with the religions of the people in India, as evidenced by the pact made by Governor-General Charles Cornwallis in 1793. It was a period of great religious debates and dialogue. However, the second stage, which began in 1813, brought Christian missionaries (with the approval of the British government) to India. The third stage marked the rise of the Indian fight for freedom beginning with the First War of Independence in 1857-58 (referred to by the British as the Great Mutiny) (Doniger 575). During this time, the British, as invaders before them, influenced Hinduism. Gandhi was a product of this British influence, so it is important that one consider what the British impact on Hindu thinking really was. 
When the British arrived, they found the caste system to be similar to their own class system. No matter what their social standing in Britain, they joined the upper classes in India. They saw the princes and rulers at the top of the social order (rather than the Brahmin priests of the Hindu hierarchy). The British made rājas of themselves, and they called their kingdom the Rāj. The Hindu caste system allowed the British to be assimilated as one more Other, and they were integrated within it as kșatriyas (Doniger 577-78). The British supported the caste system "both because they unconsciously tended to adopt the ideas of social stratification of the people they were ruling and because the Indian caste system echoed their own subtle and deeply entrenched social hierarchy" (Doniger 578). This resulted in a once relatively fluid system of social hierarchy becoming even more rigid. In addition, the British tended to prefer the company of Muslims, who were the rulers before them. They admired the Muslim's horsemanship, they related to the monotheism of Islam, and they found it easier to convert to Islam than to Hinduism (Doniger 579). Perhaps these actions by the British contributed to sowing the seed for the inter-caste and inter-faith violence in modern India, in addition to the militant Hindu ideas that had also started to develop at this time.

The growing evangelical conscience in England allowed Christian missionaries to go to India with the support of the British government. This resulted in many of the Tribal people (e.g. in Nagaland) as well as low-caste Hindus who wanted to avoid the stigma of their caste within Hinduism converting to Christianity. Others converted as a result of their involvement with the government, through intermarriage or because they were convinced by the Christian message. The government was pressured by the missionaries to intervene in Hindu matters. The government in the mid-1800s passed 
laws allowing Hindu widows to marry, allowing Hindu converts to Christianity inheritance rights, and allowing castes to mingle in railroad carriages - all of these would have been forbidden by Hinduism (Doniger 585). The British, who considered themselves as having a divine mission to rule India, were convinced of Christianity's moral superiority to Hinduism, and they lost their earlier toleration and even support of India's religions.

Religious tensions were exacerbated by British Protestants. ${ }^{63}$ In 1810, Robert Southey the English poet laureate who had never been to India declared: "The religion of the Hindoos... of all false religions is the most monstrous in its fables, and the most fatal in its effects" (qtd. in Doniger 591). Three years later, William Wilberforce argued in the House of Commons that Christianity was "sublime, pure and beneficent" while Hinduism was "mean, licentious and cruel" because Hindu deities are "absolute monsters of lust, injustice, wickedness and cruelty" and Hinduism is "the most enormous and tormenting superstition that ever harassed and degraded any portion of mankind" (qtd. in Doniger 591). After 1850, this attitude became even more common. In addition, the British also exacerbated tensions between Hindus and Muslims. In 1870, a report about the now infamous Babri Masjid noted that both Hindus and Muslims worshiped freely and together in the mosque complex until the 1850s. It was at this time that the British erected a railing to allegedly prevent disputes between Muslims and Hindus so that Muslims now prayed in the mosque and Hindus had a raised platform outside the fence

\footnotetext{
${ }^{63}$ Doniger states that Catholics who had been in India for many centuries tended to recognise within Hinduism many of their own traits (the many gods like the many saints, the pageantry, occasional brutality of the imagery, animal sacrifices like the Paschal Lamb), whereas the Protestants admired little in Hinduism but its texts and philosophy (590).
} 
on which to make offerings. The report made no mention that there had ever been any disputes or that a barrier had been necessary (Doniger 592). ${ }^{64}$

The British faced a quandary. Their scholarship showed them that the people they were conquering had the oldest language and civilisation in the world, and that that civilisation was related to the Greek civilisation which the British claimed as their own heritage. The ancient cities of Mohenjo-Daro and Harappa showed civilisational advances that had not reached Britain until the Roman period, such as running water and elaborate sewer systems. Yet, they viewed the Indians as benighted primitives. They misappropriated ideas of social Darwinism to say that the Aryan Indo-Europeans, whom they viewed as closer to themselves, had degraded their culture when they intermarried with the indigenous Indians. They translated and prioritised Sanskrit texts (over vernacular texts), even using their own interpretation of the Laws of Manu as the basis of British law in India without stopping to think the Hinduism was never a unified system, and the laws of Manu were never meant to be used in that way. The British Protestant bias in the favour of the text (scripture) completely ignored that long-standing village governing units (pancāyats) had been adjudicating in vernacular languages for centuries and already possessed their own extensive case law. In this way, the Gìtā came to be the dominant text and other texts, both Sanskrit and vernacular, were relegated to the

\footnotetext{
${ }^{64}$ The attacks on the mosque in 1992 may have been puzzling to many Hindu clerics. For them, Ayodhya is the city of Rama for the last 1,000,000 years and brick and mortar constructions are unimportant when it is the spiritual nature of the city and the place where Rama was born that is more important. The presence of a mosque at the site of Rama's birth should have been irrelevant to a Hindu since spiritual points of view are more important than what the world can prove by human constructions. It is simply a different construction of history than the Western one (See BBC's The Story of India, Episode 4 - Ages of Gold). This view is also shared by Vinay Lal who says of those Hindus who destroyed the mosque: "They are animated by a feverish sense of history and adamant in suggesting that Hinduism's truths are compatible with the findings of modern science. The ideologues of Hindutva and their supporters who demolished the Babri Masjid are historical-minded to the extent that they have, unlike Hindus of the past, historicized Hindu deities" (Lal 16). Much like political Hinduism itself, the need to historicise Hinduism is also described as a recent development and not a traditional viewpoint.
} 
sidelines (Doniger 596). In reaction, many upper-caste Hindus, in order to be seen favourably by the British began to "sanitise" Hinduism. They cleared the temples of temple dancers and prostitutes (devadāsis) and they downplayed any sign of the erotic in Hinduism in keeping with the Victorian mores of the time (Doniger 598).

The British tried to ban repugnant social customs, however, as in Ayodhya, their actions only exacerbated the situation and increased violence. One of the most important was sati - the action of certain women in India who throw themselves on the funeral pyres of their dead husbands. This practice is documented in the Mahābhārata - several queens committed $s a t \bar{t},{ }^{65}$ although, in reality, it seemed to be practised by only a small percentage of widows (mostly upper castes) ${ }^{66}$ and it had its fair share of dissenters within Hinduism itself. The British observed that some Hindu women would voluntarily immolate themselves, whereas some were thrown into the pyre by relatives. Therefore, they were torn between on the one hand, trying not to interfere with religious customs, and on the other, trying to prevent murders from being committed (Doniger 617). Some British even romanticised satī comparing it to the heroic deaths of Christian martyrs. In 1813, a British circular proclaimed that satī would be allowed in the cases in which it was countenanced by the Hindu religion and prevented in other cases (e.g. if the woman were under 16, pregnant, intoxicated, or coerced). In the first three years after the circular, the satī rates went from 378 to 839 cases annually. In 1829, a law was passed making it illegal for widows to be burned with their husbands. In reality however, perhaps out of

\footnotetext{
${ }^{65}$ Note however that most of the dharma texts do not mention sati, concentrating instead on ascetic widowhood (the laws of Manu), and some texts condemn the practice, although few texts also commend it (like the Apararka of Yajñyavalkya of $1100 \mathrm{CE}$ ) (Doniger 618-19).

${ }^{66}$ Brahmans were forbidden to commit satī, and it was usually practised by those who considered themselves to be rising in social status. Amongst the lower castes and tribal groups it was little known or unknown.
} 
fear of offending high-caste Hindus, they did not enforce the law, even sanctioning it if the woman had no children and they persuaded a magistrate that she was acting of her own free will. There is some indication that the numbers of burned widows grew because of government intervention (Doniger 620-21). This is another indication that much of the violence associated with Hinduism only worsened as a result of outside involvement, and not because of Hinduism per se. Perhaps the same can be said about the rise of militant Hinduism?

Nonetheless, some British reforms did gain supporters from many of the Indian social élite who were in contact with European and Western ideas also sought to reform these practices (Zaehner 149). Movements such as the Brāmho Samāj, founded by Rām Mohan Roy looked to the eighteenth century Enlightenment, and even Christianity, which was seen as bringing success and power to the white man and being "more conducive to moral principles and better adapted for the use of rational beings than any other" (Zaehner 151). Roy claimed to be returning to a more authentic Hinduism of the Vedas and Upanișads, however, these were to be tempered by reason and conscience, and this kind of scriptural interpretation was to influence later thinkers such as Gandhi and it "injected into Hinduism a social conscience it had never had before" (Zaehner 155). These reformers were influential in changing the law and abolishing those social practices which they deemed to be inhuman.

Other reformers, such as Swami Dayānanda Sarasvatī, founder of the Ārya Samāj, espoused a more orthodox Hinduism, and did not turn to Western or Christian thought, but back to the Veda which Sarasvatī felt had been grossly misinterpreted over the ages. He maintained that the Veda ought to be interpreted not in a 'worldly' manner but in a 
'yogic' manner since the Veda is the sanätana dharma - the eternal law that exists outside and independently of time (Zaehner 157). However, Zaehner describes both the Brāhmo Samāj and the Ārya Samāj as being sectarian movements without any real roots in Hindu society, since they abjured certain practices (like the veneration of images) that were an integral part of Hindu practice $(161,167)$.

The term "Neo-Hinduism" refers to a conception of the Hindu religion formed by recent authors schooled in both traditional Indian philosophy and who had contact with Western philosophical ideas through their education, travelling or teaching careers. Some of these modern philosophers include Swami Vivekānanda (1863-1902) the disciple of the Hindu saint Ramakrishna and India's first president, Sarvepalli Radhakrishnan (1888-1975), an academic who had teaching positions at universities in India as well as Oxford University in England. Shyam Ranganathan describes NeoHinduism as "a reformulation of Advaita Vedānta, which emphasizes the implicit liberal theological tendencies that follow from the two-fold account of Brahman" and as "a genuine, modern attempt to re-understand the philosophical implications of earlier Hindu thought". From that description, Gandhi's teachings might also fall under the rubric of Neo-Hinduism, but, as Ranganathan describes, its foundation is earlier Hindu thought and so represents a link with Vedic Hinduism.

Neo-Hinduism might be understood as a form of universalism or liberal theology that attempts to ground religion itself in Hindu philosophy. This universalism is different from the inclusivism or inclusivist theology that also existed in India. The inclusivist theology holds that many diverse religions' practices contain elements which can lead to the knowledge of the Ultimate, and that religious practitioners will ultimately learn the 
truth through their religious convictions. This theology is often expressed in the idea that the various deities are merely lower manifestations of one ultimate deity. However, universalist theology does not distinguish between deities or different religious practices. The view is that there is no religion which is incorrect, on this view, for all are equally human efforts to obtain knowledge of the divine, which is transcendental and impersonal. Therefore, all religions are viewed as different paths to God. Rather than viewing Hinduism as a religion, it is viewed as a meta-religion, or as a philosophy of religion. This viewpoint furthers the overall tolerance found in Hinduism for other beliefs. This kind of tolerance is a key component for avoiding wars based on difference of religious opinion.

\section{India Post-Independence}

The British connected the country not just with the railways, but with their administrative and juridical system and the introduction of English-medium education, which brought with it the ideas of Western philosophy. Hindu reformers in India, especially those who were educated abroad, brought ideas of secularism which they had seen in the West. They were impatient with the communal violence that they saw in India, and pressed for a secular India. Modern Indian Hindus, especially the urban middle and upper classes, are more concerned with career, affluence and better living standards than the totalising traditions of religion, with its traditional loyalties and pieties, mysticism, other-worldly concern and fatalistic explanations of suffering and inequality (see Klostermaier 444-46). However, the Hindu reform movements of the nineteenth century which may have brought about a Hindu renaissance also brought with it the 
influence of European nationalist ideology and the subsequent growth of Hindu nationalism.

For the most part, when the British left India, although Nehru did believe in the civilisational inheritance of India, he conceptualised India as a "secular democracy". Although his foreign policy towards China included the Panch Shìla or five principles derived from Hindu thought, for the most part, his policies were more shaped by realism than Hinduism (Roy, Ethics of Warfare 240). Gandhi (perhaps naïvely) advocated greatly reducing the Indian armed forces when he said on May 9, 1929:

This I know that if India comes to her own demonstrably through nonviolent means, India will never want to carry a vast army, an equally grand navy and a grander air force. If her self-consciousness rises to the height necessary to give her a non-violent victory in her fight for freedom, the world values will have changed and most of the paraphernalia of war would be found to be useless. (qtd. in Iyer 275)

Nehru, however, while maintaining a foreign policy of non-aggression had no problems with building up Indian forces for defensive purposes stating: "We live in an abnormal world, full of wars and aggression, when international law has ceased to be and treaties and undertakings have no value, and an unabashed gangsterism prevails among nations. [...] The only thing to be done to protect oneself is to rely on one's strength as well as to have a policy of peace (qtd. in Gopal and Iyengar, Vol. 1, 41).

Though Gandhi thought that those who invented the atom bomb had committed the gravest $\sin$ in the world of science (Iyer 268), in 1974, India exploded its first nuclear device, perhaps influenced by the realist thinking that a small number of nuclear weapons in Indian hands would stabilize the region (Roy, Ethics of Warfare 255). Therefore, it seems as if modern India's policies, and the rising tide of militarised Hinduism may 
represent a break with the past rather than being indicative of any Hindu ideas about warfare. As Stephen P. Cohen writes of the BJP's bomb programme:

One of the major reasons why the BJP and many secular Indians supported a nuclear weapons programme was to destroy the image of India as a "Gandhian" or non-violent country. More practically, the BJP sought to undo Nehru's legacy, with its emphasis on disarmament, peace talks, and its special opposition to nuclear weapons. By supporting the very weapons that the Congress party of Nehru and Gandhi had for so long opposed, the BJP was attempting to redefine India's political identity along new lines. (195)

At least, this break has not been total. In some cases, for example counterinsurgency ${ }^{67}(\mathrm{COIN})$ actions against the Nagas in the late twentieth century, Hindu ethics may have served to make India's COIN policy more humane - when bheda (using threats or causing dissention) was used in deference to dạ̣da (force). By contrast, the COIN policies of the British, which were shaped by a Protestant ethic (emphasising chivalry, individual sensitivities, etc.) and the American Calvinist-influenced COIN policies which indirectly emphasised brutality, were more violent in their outcomes (see Thornton).

\section{Hindu Philosophy and Hindu Nationalism}

With the rise of nationalist Hindu political parties, it might be worthy to look at the idea of Hindu nationalism in the light of developing Hindu philosophy. Klostermaier says that " $[\mathrm{t}]$ raditional Hinduism $[. .$.$] cannot possibly provide an ideology for Hindu$ political parties" (461). Yet, there has been a continual rise of Hindu nationalist political parties and the rise of Hindu fundamentalism. However, as C. Ram-Prasad explains:

\footnotetext{
${ }^{67}$ Roy defines insurgency as an organised movement aimed at the overthrow of a constituted government through the use of subversion and armed conflict (qtd. in Roy, Ethics of Warfare 247.)
} 
Many of the developments through the twentieth century that ostensibly were motivated by concerns of religion are arguably products of more general concerns about identity, ideological historiography, political power, and economic share. Few issues [...] are obviously religious in content, if by "religious" we mean anything pertaining substantively to the attainment of transcendence, or even a socio-ethic founded on commitment to transcendence. (526)

In 1909, the Hindu Mahā-sabhā, a right-wing militant Hindu party was founded by Pundit Mohan Malaviya. The party advocated a Hindu awakening and that India, or Hindustan, being the land of the Hindus, ought to be a Hindu state based on Hindu culture, tradition and ideology and that politics ought to be hinduised and Hinduism ought to be militarised (Klostermaier 463). The rise of militant Hindu nationalism can be traced to anti-colonial movements of the late nineteenth century. However, after 1947, it was used to try to create a Hindu India in accordance with Hindutva, which can loosely be defined as the socio-cultural factors that unify Hindus (Klostermaier 463). There was a perception that Hindus were being subjugated by Muslims or Christians, and that steps had to be taken to safeguard Hindu rights. Some, Hindutva organisations such as the Rāṣțrīya Svayam-sevak Sañgh (RSS), founded by K.B. Hedgewar in 1925, declared Muslims, Christians and Communists (in that order) as major enemies of India, and advocated stripping non-Hindus of their citizenship (Klostermaier 467). Hindu nationalist supporters regard non-Hindus to be "foreign" to India because their faiths have holy lands outside the boundary of the modern Indian State. Opponents claim that these Hindutva organisations emphasise brahmanical and upper-caste practices, and that the Hindutva agenda compromises the well-being of Dalits (the former "untouchables"), the poor and lower castes (sometimes referred to as the "backward castes" in India), the adivasis (indigenous tribal peoples), as well as the religious minorities such as Buddhists, 
Sikhs and Jains who are considered anti-national and anti-Hindu (Jones and Ryan 185-6). The creation of the state of Pakistan for Muslims and the large-scale violence and displacement it produced still fuels the fires of hatred and provides mutual resentment between Hindu and Muslim groups in the subcontinent. Gandhi was assassinated by a former RSS member, Nathuram Godse, who felt that Gandhi was too accepting of religious minorities with his idea of a secular India (Jones and Ryan 185-6). Godse, greatly influenced by the literal interpretations of the Gìtā by B.G. Tilak later said that he had done his duty like Arjuna in the Mahābhārata whom Kṛ̣na advised to kill his own relatives because they were evil (Kuruvachira 29).

\section{Militant Hinduism: B.G. Tilak}

Prior to the arrival of Gandhi, Bal Gangadhar Tilak (1856-1920) was another key nationalist figure and in 1909, while in a prison in Rangoon (modern day Burma), he produced a translation and commentary on the Bhagavad Gîtā. However, Tilak's interpretation of the Gîtā represented a break from tradition (Kapila 445). Unlike Gandhi, who viewed Hindu/Muslim relations as fraternal because he viewed people's Indianness as more relevant to national identity than religion, Tilak saw non-Hindus as enemies, much as the kinsmen in the war in the Gitta were enemies (Kapila 440). While Tilak did not cause Partition, his thinking did make the violence possible. More will be said about Tilak in the next chapter, however, what seems clear from many sources is that this brand of militant Hinduism or religious nationalism was a nineteenth century phenomenon, and many of the supporters of this kind of Hinduism were influenced by European Orientalism (see Gier). Tilak himself was versed in the Western political 
tradition, however, he only endorsed Nietzsche (Kapila 446). Tilak undoubtedly set the stage for ultra-nationalistic and militant Hindu parties of the twentieth century.

While Tilak sought to exclude non-Hindus from political power, other Hindutva organisations did not and even invited them to join Hindutva organisations. Even the RSS under its third supreme leader (Sarsangcachalak) Madhukar Dattatreya (1973-1994) advocated a broader definition of a Hindu Rāșța (Hindu Polity or State) which included "those who believe in the one-culture and one-nation theory" of India and was not limited to any particular faith (Klostermaier 467). But some activities, ${ }^{68}$ such as the reclamation of Hindu sites that were seen to be usurped by invading conquerors, have led to interreligious clashes.

In 1966, the Shiv Sena (Shivaji's army) was founded in Bombay by Bal Thakkeray, to protect the rights and jobs of people in Bombay and in the state of Maharashtra. In 1969, a general strike was organised in Bombay, and there was burning of buses and trains, looting and burning of shops and businesses of non-Maharashtrians (Hindu and non-Hindu). The most recent incarnation of the RSS's political wing is the Bhāratiya Janata Party (BJP), created in 1980, which advocates and supports the Hindutva agenda.

On December 6, 1992, thousands of Hindu activists demolished the Babri Masjid, and this was followed by large-scale rioting, burning and looting in major Indian cities. The leaders of the BJP, VHP and RSS incited Hindu nationalist mobs to destroy the mosque which had stood in Ayodhya (Uttar Pradesh) for over four hundred years, supposedly on the grounds of a Hindu temple which marked the birthplace of the god

\footnotetext{
${ }^{68}$ Other Hindutva goals include calls for the reunification of India, the introduction of Hindi as the national language, the recognition of the state of Israel, and the ban of cow slaughter.
} 
Rāma ${ }^{69}$ In the spring of 2000, 58 Hindutva activists were torched on a train near Godhra (Gujarat) which resulted in terrorism and the massacre of Muslims throughout Gujarat. Muslim homes, businesses and mosques were destroyed, and burned. Women and girls were sexually abused and mutilated as well as burned to death. The result was over 2,000 deaths and over 200,000 displaced, the majority of whom were Muslims. Human rights observers classified these events as "genocide" under the UN Genocide Convention of 1948 and India's government found the Gujarat government complicit "at the highest levels". These events have led to the formation of Hindu nationalist groups within India and the diaspora, such as the India Development and Relief Fund (based in the US) and the Hindu Swayamsevak Sangh (based in the UK). These groups are reported as actively supporting forced conversions of Christians and tribal people to Hinduism, destroying churches, committing selective murders, imposing social and economic boycotts of minorities, and imposing a ban on cow slaughter, which threatened the livelihoods of poor Muslims and Dalits (see Jones and Ryan 187).

However, the parallels claimed between Hindutva, which tries to convince people of the need for a Hindu Rāstra and the rule of dharma of Indian rulers of the past, are impossible to reconcile. The symbiosis between traditional monarchies and traditional Hinduism is vastly different from the party politics of an idealised Hinduism of today. In traditional Hinduism, the role of the king was primarily for the well-being of his subjects, and the focus was primarily on ethical concerns rather than the focus on sectarian affiliation and religious ideology which seem to be the concern of some Hindu nationalist parties. The traditional yatidharma forbids a samnyāsin (a renouncer which is what all

\footnotetext{
${ }^{69}$ Michael von Brück describes the myth of the birthplace of Rāma as "an idealogical construction made up for political reasons and the creation of a Hindu identity against the threat of Islam, as militant Hindus would see it" (11).
} 
Hindus aspire to in their last stage of life) from involvement in political or economic affairs (Klostermaier 471). However, events such as those in Ayodhya indicate that while the large, modern, educated Indian middle-class may be in favour of secular ideas and would not condone violence or rioting, many are nonetheless sympathetic to the ideology of Hindu nationalist political movements.

\section{Summary of Hindu and Christian Political Thought}

In brief, Hindu political ideas can be divided into two distinct types, one associated with the sacred texts of the brahmanical canon, the others from the more secular (but still highly religiously influenced) Arthaśāstra and the Nītiśāstra. First, one must note that the polity of the Hindu thinkers does not correspond either to the polis of ancient Western philosophy nor the nation-state of modern times, but refers to a different kind of entity, which Ghoshal calls a "country-state" which is charged with an ethical meaning and purpose and essential for the well-being of its people. The king is seen as the main instrument for repressing man's evil tendencies. These evil tendencies are the result either of a collapse of a once pristine state of nature, or that the state of nature itself was one of anarchy and chaos at the start. The main responsibility of the monarch, therefore, is to protect the people from anarchy, and therefore, at first glance, seems to parallel the ideas of Plato and Aristotle. However, there are two distinctions in Hindu theories. First, the state as represented by the king does not directly promote the good life nor is it a creator of goodness, rather, it promotes virtue indirectly by the agency of the prescribed duties (dharma). Second, the state is not the instrument by which the individual will reach absolute fulfilment. The state is one necessary stage of fulfilment, 
but absolute fulfilment can only be attained by the individual reaching self-realisation without need for the community or the state (see Ghoshal 266-67 in footnote).

When considering the place of the individual in society, Hindu political theory has three lines of approach. First, Hindu authors conceive of a social ordering of people led by a king who rules by the will of the divine. This idea views society as an expression of the cosmic order or the universal law. Second, there is an idea of a contract between the king and subjects as found in the Laws of Manu and the Mahābhārata. This kind of thinking may have arisen in response to Buddhist texts that promoted individualistic tendencies rather than the idea of social ordering based on previous birth. The third approach is the brahmanical idea of social order which implies that the individual is charged with certain duties which owe their existence not to the will of the king or the state but to the will of the divine (Ghoshal 267-68). However, there are no clear-cut divisions between these approaches, and often theories of divine right are combined with social contract theories (see Ghoshal 273-74).

Owing to its conception of the country-state, a larger entity than the Greek citystate, Hindu political theory makes a distinction (although not a complete one) between the state and society. In the brahmanical social order, the king's function does include both political and domestic activities, but the essential task of the king is emphasised as governing the people and administering justice. Like the State in medieval Europe, the brahmanical social order seems to have a dualism of Church and State by its differentiation of the ruling/fighting ksatriya and the teaching/sacrificing Brahmins. However, no distinction is ever made between secular and religious concerns. Both are linked and both are seen as necessary for the fulfilment of the individual (Ghoshal 268). 
In a similar vein, unlike in mediaeval Europe, the King is not accountable to God alone, but the Brahmins were thought of as being qualified to supervise the King's conduct. Also, the Hindu theory contains no doctrine of an indefeasible hereditary right to rule, which was an essential element of the Western approach of the divine right of kings (Ghoshal 278).

Ghoshal states that "none of the Hindu theories approaches the character of a system, and that while embodying rational speculation they are placed in a mythological setting" (274). He contrasts this with the example of Hobbes, whom he sees as the "author of a great system uniting in itself the principal currents of contemporary thought" (274). This difference in the character of their political thought may explain why the idea of just war is so enduring in Western political thought as it is viewed as a continuous and unbroken stream of thought that was built upon by successive thinkers. In Hindu political writings, works like the Arthaśāstra or the laws of Manu, and certainly Tilak's writings seem to be breaking with past traditions, and thus never approaching the character of a system.

\section{Conclusion}

This chapter has explored some of the key Hindu political and religious texts in order to uncover how rules of warfare were created in India. Many of the rules enumerated by Hindu texts can indeed provide us with ways to augment or alter some of the ideas that have been ingrained in international law for over three centuries. Regarding the just war doctrine, I have shown that Christianity is not unique in promulgating a just war doctrine. However, if one tries to discover a parallel to the 
Christian just war tradition in Hindu thought, just war criteria are not only more restrictive, but also more comprehensive, including post bellum recommendations. The king is seen as having a duty to protect his subjects and to maintain peace and order, using the sword if necessary. Soldiers have to be recruited from a warrior caste, although there have been deviations from this in some texts (e.g. Laws of Manu), and combat must be between equals.

At first glance, a Hindu theory of the just war, presents itself readily in Indian political texts. There are many instances of rules regarding the conduct of warfare to be found in the Hindu epics, in the Arthaśāstra and in the Laws of Manu, but no detailed consideration of ad bellum criteria. But perhaps owing to the restrictive fighting rules, Hindu political entities tended to remain smaller semi-autonomous kingdoms controlled by a hegemonic power. Such a polity did not distinguish between internal and external conflicts or between internal and external enemies, therefore impacting how a code of conduct during a battle would be expounded. Moreover, rules of warfare in the epics are viewed by some as idealised rules for divine wars and not earthly wars. Ultimately, the rules of warfare in the Arthaśāstra were abandoned, and even the Laws of Manu ceased to have enduring influence. This is in contrast to the seemingly uninterrupted just war lineage from Augustine onwards that pervades in the Western tradition. With the abandonment of the Arthaśāstra and the Laws of Manu, some of the more non-violent aspects of Hinduism were allowed to come to the fore. Also, the increasing importance placed on the Gītā further favoured non-violence as a form of political activity, and this culminated in the methods of Gandhi. This secured Hinduism's reputation as a peaceful religion. In the next chapter, the metaphysical assumptions of Hinduism will be 
examined, and, in tandem with the allegoric interpretations of the Gìtā, it will be shown how the non-violent interpretations of Hinduism developed.

Perhaps a return to Hindu ethics in India, and an examination of Indian ethics by the rest of the world would yield positive outcomes and reduce levels of violence. Perhaps Indian philosophy writ large could make a valuable contribution to the world (Subedi 358). Subedi states that "the Hindu laws of war seek to make war more humane than the modern laws of war based on the Geneva Conventions" and that "the world would be a better place to live in if the modern laws of war based on the Geneva Conventions were to incorporate some of the rules of Hindu laws of war" (360). He bemoans the fact that after Indian independence and the creation of the modern state of India, secular policies were implemented, Western principles of government were adopted, and the influence of ancient Hindu principles was greatly weakened. Thus even the modern state of India has ignored the potentially beneficial principles of her Hindu past (see Subedi 359). 


\section{Chapter 4 - Hindu Theology, the Bhagavad Gītā and Warfare}

Once more the world must be conquered by India. This is the dream of my life. I am anxiously waiting for the day when mighty minds will arise, gigantic spiritual minds who will be ready to go forth from India to the ends of the world to teach spirituality and renunciation, those ideas which come from the forests of India and belong to Indian soil only. Up India, and conquer the world with your spirituality. [...] Ours is a religion of which Buddhism, with all its greatness is a rebel child and of which Christianity is a very patchy imitation. (Swāmi Vivekānanda qtd. in Klostermaier 438)

\section{Introduction}

India is a mosaic of different cultures, languages, religions, races and foreign influences that has held together, notwithstanding the relatively recent partition and creation of Pakistan and Bangladesh. Many of the metaphysical assumptions of Hinduism, unlike those in the West, which were highly influenced by Greek philosophy, form an independent stream of thought that continues to influence countries like China, Japan, Tibet, Myanmar, Sri Lanka and Cambodia (see Radhakrishnan, The Hindu View of Life 1). These assumptions also influenced how Hindu thinkers formulated their political ideas.

It is these foundations that will be further examined in this chapter. I will look at the key elements of the Hindu worldview and will examine how these elements contrast with the elements in an Augustinian worldview. It will be shown that the differences in belief could contribute to decreasing the number of wars and reducing the intensity of death and destruction during warfare. 


\section{Hinduism Defined}

Unlike in Christianity, there is no official declaration of faith or creed in Hinduism. In a 1966 case of Sastri Yagnapurushadji and Others v. Muldas Brudardas Vaishya and Another, the Supreme Court of India was called upon to decide whether a certain sect constituted a distinct and separate religion from Hinduism, and consequently, in its decision, the court had to first determine what defined the Hindu religion. Using both scholarly texts from Indian and non-Indian scholars the Court declared that it was

difficult, if not impossible, to define the Hindu religion or even adequately describe it. Unlike other religions in the world, the Hindu religion does not claim any one prophet; it does not worship any one God; it does not subscribe to any one dogma; it does not believe in any one philosophic concept; it does not follow any one set of religious rites or performance in fact, it does not appear to satisfy the narrow traditional features of any religion or creed. It may broadly be described as a way of life and nothing more. (Yagnapurushadji 261)

However, after describing what the $\operatorname{Hindu}^{70}$ religion is not, the court did list some

features which it defined as "broad concepts which can be treated as basic":

1. Acceptance of the Vedas with reverence as the highest authority in religious and philosophic matters and acceptance with reverence of Vedas by Hindu thinkers and philosophers as the sole foundation of Hindu philosophy;

2. Spirit of tolerance and willingness to understand and appreciate the opponent's point of view based on the realisation that truth is manysided;

3. Acceptance of great world rhythm - vast periods of creation, maintenance and dissolution follow each other in endless succession;

4. Acceptance by all systems of Hindu philosophy of the belief in rebirth and pre-existence;

5. Recognition of the fact that the means or ways to salvation are many; and,

6. Realisation of the truth that numbers of Gods to be worshipped may be large, yet there are Hindus who do not believe in the worshipping of idols. (Yagnapurushadji 264-266)

\footnotetext{
${ }^{70}$ It is interesting to note that the term "Hindu" and the formation of Hinduism as a world religion has only occurred since the nineteenth century when it was used by Hindu reformers and western orientalists (Flood 8). Hinduism is often referred to as Sanātana Dharma, meaning "the eternal law", by its adherents.
} 
I will now examine some of these broad concepts in greater detail.

\section{Sacred Texts}

Indian sacred scriptures can be broadly divided into two classes: the most holy and oldest is the s'ruti, "that which is heard", and it includes the four Vedas and the Upanișads, which are also called Vedānta, or the "End of the Vedas". These texts also have appendages or Vedāngas. The second class is smṛti, "that which is remembered", and are a series of legal and ethical texts, as well as the Itihāsa-Purāna, which include the great epics, the Mahābhārata and the Rāmāyaṇa, the former of which the Bhagavad Gîtā is part of (Basham 69-70). One of the most important features of Hindu theology and philosophy is that it is expressed through commentaries and exegesis of these sacred texts. The Sütra texts contain short aphorisms which summarise the teachings of a particular school of thought. The bhāsyas are extensive commentaries on the sūtras, and there are also the short explanations (vrtti) and further explanations of commentaries (vārttika).

\section{Śruti (Heard or Revealed) Texts: The Vedas and The Upaniṣads}

Vedic society was divided into three castes - the priests (brāhmaṇa), warriors or rulers (kștriya, rājanya) and commoners (vaiśya). A fourth serf caste (śüdra) was formed later in the Vedic period. ${ }^{71}$ This structuring of society is based on sacred revelation. ${ }^{72}$

\footnotetext{
${ }^{71}$ While some Indian philosophers and Indologists (including Flood, Zaehner and Basham) seem to describe the Śudras as the Dravidian people who were conquered by the Āryans, Kumar notes that this is not the view held by most scholars and that such a view cannot be substantiated from Vedic texts. He says that rather, the Dravidians were not included in the caste system because they were considered as slaves having no rights in the society of their Āryan conquerors. Also, the Dravidians had a different religious
} 
The Vedas refer to ancient texts, handed down orally through generations of Brahmins, the oldest of these texts being the Rg-Veda, being composed between 1500 and 900 BCE. The Vedic texts emphasise the importance of the power of speech $(v \bar{a} c)$ through which truth is revealed. The language of the Vedas, (Vedic, or Vedic Sanskrit which was a precursor to the Classical Sanskrit of the fourth century BCE), was seen as a perfected language, through which revelation could be communicated, through the seers (rssis) to humanity.

The Rg-Veda asks questions about the origin of things, and whether in the beginning there was existence (sat) or non-existence (asat), and what is there beyond death. The word "Veda" means knowledge, and is a cognate with the English word "wit" or the German verb "wissen" (to know). They are thought of as being scrupulously preserved and passed on by oral transmission because these texts are regarded by some Hindus as timeless revelation which is not of human authorship (apaurușeya). They were regarded as eternal and containing all knowledge; writing these texts down was seen as polluting them. Others regarded the Vedas to be the revelation of God, received or seen by the rșis who communicated them to other men, and eventually, according to tradition, they were compiled together by the sage Vyāsa. The primary function of the Veda is a

heritage and did not come under the priestly influence because they did not offer sacrifices to the Āryan gods. With the development of Vedic religion, which combined elements of Dravidian thought, the Dravidians eventually did become part of the caste system and part of society (Kumar 34-35).

${ }^{72}$ It is true, that the indigenous caste is often designated as dasyu or enemy in the Rg-Veda. They are also labelled with a variety of negative epithets, often beginning with the Sanskrit prefix for negation ' $\mathrm{a}$ '. They are called a-brahman (prayerless), a-deva (godless), adhara (inferior), a-mānuşa (inhuman), a-mantu (unthinking), an-ās (flat-nosed), apa-vrata (opposed to religious rites), a-prynat (stingy), a-śrāaddha (unbelieving), a-vrata (not observing religious rites), a-yagya (not offering sacrifices), a-yajyu (impious), $a$-śiva (unkind). They are also referred to as sişna-deva meaning "whose god is a phallus" (Hume 34-35). However, Hume notes that these Indo-Aryans later succumbed and adopted many of the beliefs of the people they conquered. This can be seen by the adoption of the Siva-lingam as an object of worship, but also in the adoption of many linguistic characteristics of Dravidian languages, such as retroflexive consonants, which were adopted by the Aryan languages (Hume 34-35). 
ritual one as it is primarily a liturgical text (Flood 36, 39). However, the contents of Vedic hymns reflect earlier traditions about the divine, the origin of the world and human society, although these hymns reflect the sense of cosmic mystery and scepticism that Hinduism embodies (Flood 47). Gavin Flood notes, however, that "the actual content of the Veda has often been neglected by Hindu traditions" but it is nonetheless "a reference point for the construction of Hindu identity and self-understanding" (11). Arthur Basham explains that this neglect is perhaps owing to the fact that although accurate oral transmission of the text was very high, often most of the Brahmins "had only the vaguest notions of its meaning, because its language is so archaic that it is almost unintelligible to one trained only in classical Sanskrit" $(7,9)$. The Rg-Veda was never a popular text, and its main appeal was for the religious aristocracy by and for whom the text was composed, and this aristocracy were the Âryans who were intruders into the lands of the Dravidian peoples of the sub-continent (Basham 10). ${ }^{73}$ This is one of the reasons that in my analysis of texts, the more popular Bhagavad Gītā will be mined for ideas about warfare.

Following the earlier portions of the Vedas are the Upanișads, which are more systematic and consist of dialogues between teacher and student (Upa meaning "near", $n i$

\footnotetext{
${ }^{73}$ Note that I do not hold that the Āryan invasion theory necessarily gives an accurate account of ancient Indian history, but I do recognise that the meanings of these texts were lost as the Āryan language changed and developed into Classical Sanskrit. Many Indologists, claim that Indian philosophy is entirely Vedic (Āryan) however, a less biased and less sectarian view recognises that Indian philosophy and theology is based on the combined cultural and religious traditions of both the Āryan and pre-Āryan (Dravidian, Mohenjo-dāran, Harrāpan) civilisations. The Āryan strain of thought may have been more systematic, reflective and logical, however, the non-Äryan strains contributed greatly to the emotional and spiritual development of individuals and were especially important in the formation of Yoga and bhakti movements (Zaehner 15, see also Kumar, 4, 16). Note that many modern historians in India believe that the Āryan invasion story gained acceptance because it was favoured by the British, who, in keeping with the colonial attitudes of the time, thought that nothing of importance could have come natively from India, but that it was brought there from Central Asia by invaders. Modern archaeological evidence seems to suggest that the Mohenjo-dāran and Harrāpan civilisations failed because of environmental factors (inter alia desertification, drying up of the Saraswati) which forced these peoples to move southwards, and perhaps only centuries later, in around $1500 \mathrm{BCE}$, Āryans rode in and gradually mixed with the population. (See Paul W. Robert, "Mahābharata - Myth or Truth: A Critical Analysis").
} 
meaning "devoutly" and șad meaning "sitting) (Kumar 39) on metaphysical, axiological and cosmological issues. The mythology of the Vedas was dissatisfying to the poets who were no longer able to discuss the profound problems they were facing and to solve them in a rational manner, so they expressed new ideas by inventing new myths (Basham 20). The Upanișads identify existence (sat) with Brahman who is the ultimate reality - the supreme deity, the breath of the universe, the omniscient, omnipotent and omnipresent entity hidden from plain view, but known through philosophical speculation that is driven by dissatisfaction with earthly rewards. Rather than the focus on action (karma), there is a focus on knowledge (jñana) of Brahman whom the Upanișads also identify with ätman (Self, or soul) and suggest that knowing Brahman and knowing of one's relationship to Brahman will save one from all sorrow and result in liberation. These Upanișads are referred to as the jñana kānda ("knowledge portion", the uttara mìmāimsā ("higher inquiry" or the Vedānta, which means "end of the Vedas" (see Flood 242). These secretive and esoteric texts contained various prohibitions against divulging the knowledge contained within them (see Hume 37). The religion of the Rg-Veda as "thiswordly" contrasts with the "inwardness" of later texts such as the Upanișads (Zaehner 15). The duty of the ancient r̦șis who heard the Vedas, was "to ensure the ordered functioning of the world and of religious ceremonial [sic] by reproducing the succession of cosmic events, the ordo rerum in their acts and in the imagery they conceived" (Zaehner 18). It is this reproduction of the cosmic order (rta) on which human order, ethics and social behaviour depend. The cosmic struggle is reflected in Indian mythology and the stories of the gods. Rta "can be translated as 'cosmic order', 'law', 'truth', or 'reality' : it is both the ordered universe as it is in itself and the order that pervades it; and 
this order is as applicable to the moral conduct of men as it is to the macrocosm of heaven and earth and to the sacrifice that mirrors them macrocosm in parvo" (Zaehner 31). This rta is the historical Vedic origin of the later term dharma which becomes a key concept that influences the pantheistic and monist character of modern Hinduism (Zaehner 35-38).

\section{Smṛti (remembered) Texts: Mythological Epics and the Bhagavad Gītā}

The smrti texts are more numerous, and are based upon the learning of the Vedas. They were regarded as appropriate for general consumption, unlike the esoteric and secretive śruti texts. These texts were originally written in Sanskrit, but later came to be written in and also translated into vernacular languages. These texts attempt at unifying the goals of the action portion of the Vedas (which focus on ethics and dharma) and the goals of the knowledge portion which focuses on liberation (mokșa). The smrti texts affirm the morality of the social structure of class (varna) with that of stage in life (áśrama) in the concept of varna àśrama dharma. They propose different stages of life for the individual, each with different goals. ${ }^{74}$

The main kinds of smṛti literature are Itihāsa, Purāṇa and Dharmaśāstra. The itihāsas include the great Hindu epics, the Mahābhārata and Rāmāyaṇa. The purānas are a group of texts (whose composition postdates the Vedas) that provide a history of the

\footnotetext{
${ }^{74}$ The four goals of man according to Hinduism are kāma, artha, dharma and mokșa which are prioritised in different stages of life. At the end of childhood, and before the beginning of adolescence, an individual is typically expected to be a celibate student (brāhmacārya), and learn the ways of one's caste. Then at an appropriate age, they are to marry and become a householder (grhastha). During this stage an individual is permitted and expected to pursue the ends of kāma or sensual pleasure through married life and artha or economic prosperity through caste occupations. After raising a family, a couple is to retire to the forest and become forest dwellers (vānaprastha), to facilitate their transition from a life focused on kāma and artha to a life geared towards liberation. Finally, individuals give up all possessions, renounce society and become ascetics (saimnyāsa) at which point they are to focus solely on mokșa or spiritual liberation.
} 
origin of the various deities and the universe and are written in praise of the exploits of a particular deity. The Dharmaśästras are texts on the science (śāstra) of dharma. To fulfil one's dharma, the ritual action of a Brahmin must be pure (shuddhi). This implies a ritual purity of the body (principally by water) but also a purity of social organisation the maintenance of order and structure of society and the maintenance of strict boundaries between social groups and genders, marriage regulations, etc. (Flood 57). This body of literature was authored by Brahmins, in order to reinforce their privileged or elevated position within the social-caste hierarchy. While they do contain accounts of the origins of the universe, and question how mokșa is to be obtained, their main focus is to prescribe the specific duties and privileges of each caste. They focus on ritual expiation (prayaścitta) as a means of atonement for moral transgressions. These smrti texts, especially Manusmṛti, known as the Laws of Manu, have come under increasing criticism for their harsh treatment of women and of lower castes. The British interpreted Manusmrti as a legal code rather than viewing it in terms of a code of social or ritual conduct, and in doing so may have exacerbated caste differences (Thapar 2-3). Burjor Avari says of Manusmrti:

The text was not followed or acclaimed by the vast majority of Indians in their history; it came to the world's attention through a late eighteenthcentury translation by Sir William Jones, who mistakenly exaggerated both its antiquity and its importance. Today many of its ideas are popularised as the golden norm of classical Hindu law by Hindu universalists. They are, however, anathema to some modern thinkers. (Avari 142)

The most important component of the Mahābhārata is the Bhagavad Gîtā (meaning "Sung by the Lord" (Basham 82) or "Song of God"). It is often regarded as a stand-alone text, and is the most beloved and widely read of Indian scriptures. It was 
composed between the second century BCE and the second century $\mathrm{CE}$, is probably the most important text in Hinduism from which inferences about a Hindu philosophy of war and soldiering can be gleaned. Its content suggests that it was composed at a time when the ethics of warfare, martial values and the idea of the kșatriya dharma were being questioned (Basham 96). It continues the Upanișadic traditions in which the conception of God becomes more personal, and more engaged in the activity of this world. It is the source of bhakti, as devotional religion in India (more will be said about this later). Klostermaier describes the Bhagavad Gītā as the most important, popular and authoritative text of the Hindu sacred corpus and says that "many are convinced that the Bhagavadgītā is the key book for the respiritualization of humankind in our age" (Klostermaier 99). The Gītā has been considered by many Indians and non-Indians as a book to be read and studied as a guide in their lives, especially in times of spiritual crisis (Klostermaier 109). Gandhi spoke of the Gîtā as his mother and he saw in it "an allegory of human life, which as to fight out the dilemma between divinely ordained duty and personal preference (Klostermaier 101). Because the Gitā is mainly the sermon of the Lord Kṛ̣na to Arjuna, it has taken on the status of a śruti text, and is even considered as an Upanișad. ${ }^{75}$ Many regard the teachings of the Gitā as being applicable in our own time, although it is not easy to establish the universal applicability of the ethics of the Gìtā because the text is complex and requires a guide to understand the historical and philosophical problems it presents (Klostermaier 109).

The śruti texts (which include the Vedas, the Upanișads, and, according to the Vedāntists, the Bhagavad Gītā) have "a plasticity that permits new understanding, the

\footnotetext{
${ }^{75}$ A. C. Bhaktivedanta Swami Prabhupāda in his introduction to his translation of the Gītā entitled Bhagavad Gìtā as it is refers to the Gìtā as the Gìtopanişad and describes it as "the essence of Vedic knowledge and one of the most important Upanișads in Vedic literature" (Prabhupāda xix).
} 
words have a reservoir of meaning, a power of evoking and challenging thought" whereas smrti (which include the Laws of Manu) are "relatively fixed in their connotation, and ask you to obey rather than understand" (Mohanty 275). It is perhaps because of this plasticity that the Gītā has been interpreted by some as a call to arms. If these texts are apauruseya, there is no need to reference the experiences and intentions of their authors; Mohanty, and many thinkers like him, including Gandhi, advocate interpretation of these religious texts in the light of their own experiences (Mohanty 282). In doing so, they apply allegorical interpretations of the text, and non-violent interpretations are more commonplace. However, unlike the certainty of some religious traditions, Hinduism makes room for uncertainty. ${ }^{76}$ For example, for Muslims, the Qur'an is a facsimile of a heavenly book dictated by the angels to Mohammed, and therefore, represents an eternal Truth, that Muslims are to follow if they wish to submit to the will of Allah. As Eliade explains, in Indian philosophy, "truth is not precious in itself" and therefore, it is not possession of truth that is sought, but it is liberation, which is the conquest of absolute freedom. Liberation is transcending the human condition and approaching another plane of existence, rebirth to a non-conditional mode of being, dying to all that is human (Eliade 4). If this idea of liberation is believed, then allegoric interpretations of the Gîtā seem more appropriate. I will later examine the Gītā's message more thoroughly in my investigation of the just war doctrine. There are some differences in the metaphysical views of the various schools of Hindu theology, and these will be discussed later, however, I will now present an overview of some of the basic terms and ontology.

\footnotetext{
${ }^{76}$ For example, the mysterious creation hymn of the Rg-Veda, 10.129 ends with the inconclusive words: "Whence this emanation has arisen, whether [God] created it or whether he did not, only he who is its overseer in highest heaven, knows. [He only knows] or perhaps he does not know" (qtd. in Zaehner 42).
} 


\section{Dharma}

Dharma is revealed by the Veda, and is equivalent to the word "religion" although it incorporates a wider meaning, including 'truth', 'duty', 'ethics', 'law', 'religious merit', 'principle', 'right' and 'natural law' (Flood 11, 52). Specifically, dharma refers to the duty of high-caste Hindus with regard to social position, caste or class (varna) and the stage of life they are in (aśrama). It is an all-encompassing ideology which embraces both ritual and moral behaviour, whose neglect would have bad social and personal consequences (Flood 53). Flood states that in Hinduism, practice takes precedence over belief, and that a Hindu's actions are more important than his belief. Adhering to dharma relates, therefore, to the performance of certain duties (for example, rituals of purity, who performs these rituals, etc.). He quotes Frits Staal who says that a Hindu "may be a theist, pantheist, atheist, communist and believe whatever he likes, but what makes him into a Hindu are the ritual practices he performs and the rules to which he adheres, in short, what he does" (12). The source of authority comes from the highest caste, the Brahmins.

Dharma implies a distinction between the acceptance of worldly life and social values, and renunciation (samnyāsa) (the rejection of worldly life) in order to achieve salvation or liberation (mokșa). In other words, there is a distinction between the practical needs of daily life for the community (which Richard Gombrich calls 'communal religion') and placing the individual on the path to salvation (which Gombrich terms 'soteriology' (Flood 13). Dharma is expressed in the domestic realm by the ideal Brahmin (high-caste householder) and in the political realm by the ideal king. 
The Brahmins and the king were intimately connected, as the Brahmins' power was legitimised by the king, but the consecration of the king was performed by the Brahmins.

At a universal level, dharma relates to an eternal, cosmic principle, but it also relates to the level of human transactions. One of the sources of these laws, according to Manu, could be custom. Therefore, dharma is context sensitive and differs according to age, caste, class, family, region and country. As Manu says: one's own duty, [even] without any good qualities, is better than someone else's duty well-done (Flood 58). The duty of the Brahmins is to teach the Veda and sacrifice for others. The ksatriya have to practise with arms and protect the people. The vaisya should tend cattle, practise agriculture and money-lending, and the śüdra should serve the other classes and practise art. This stratification of society corresponds to a scale of ritual purity and pollution, which the Brahmins at the top and the śüdras at the bottom. While the Brahmins create a ritually pure environment, so the King must create a kingdom in which there is good fortune and prosperity, as has been discussed in the previous chapter.

\section{The Relationship between God and Man: Brahman and $\bar{A} t m a n$}

Many people often mistake the many aspects of the personal deities as represented in Indian art, sculpture and literature as representations of polytheism. However, this is a misunderstanding when one considers the impersonal Brahman that is at the core of Hindu theology. Brahman can be translated as "sacred formula" or "sacred action" - and the word God is often used as a substitute for Brahman (Zaehner 37). God may take human form (avatārs) and enter the world through his grace to establish righteousness. 
This theistic, monist philosophy that all deities are manifestations of a single power (Brahman) is especially reflected in the Upanișads (Flood 44). ${ }^{77}$

In the later Vedic period, polytheism developed into pantheism - "What is but one the wise call [by] manifold [names]" (RV 1.164.46). The poet in the tenth book of the Rg-Veda expresses the need for a real god to worship - the god from which an ordered universe emerges from chaos (Zaehner 41). God both is the universe and transcends it (Zaehner 43). The four different castes or classes arise from different parts of the creator: the Brahmins from his mouth, the rājanya, later called the Ksatriya (the warrior and ruler) from his arms, the Vaiśya (peasants and craftsmen) from his thighs and the Śúdras from his feet. "[T]he moon was born of his mind, the sun from his eye, Indra and Agni [the warrior god and the priest god, respectively] from his mouth, Vāyu, the wind god, from his breath, the air from his navel, the sky from his head, the earth from his feet, and the cardinal points from his ear" (Zaehner 44). The creation of the world is an act of sacrifice, and the earth is a microcosm for the macrocosmic sacrifice of the Primal Man, i.e. the Creator, who is simply called Puruṣa or 'Man'. Since the act of creation results from sacrifice, the continued orderly existence of the universe also relies on the repetition of that original sacrifice on the microcosmic scale (Zaehner 44, Basham 30). At first, these were animal sacrifices, practised on a huge scale, as well as sacrifices of the sacred plant soma, and offerings of milk, sweets and vegetables - the latter slowly replacing the former blood sacrifices. The purpose of the sacrifice was to offer a gift to the gods, for which the gods would return long life, many offspring, wealth, health, victory and other good things of the world. It was also to remove sin committed through

\footnotetext{
${ }^{77}$ This monist idea is said to represent the beliefs at the "elite" level and not popular level Hinduism, however, it will be discussed here as it is part of the Advaita Vedānta viewpoint that I am trying to contrast with Augustinian Christianity.
} 
contact with taboo objects or incorrect performances of the ritual. It was also a communal meal, shared between man and the gods (Zaehner 45).

Along with the development of a personalised creator-entity (purușa), there is a tendency in the Brāhmanas and the Upanișads to elevate some impersonal force to the position of supreme principle of the universe - the sacred utterance or Brahman (later becomes personified as Brahmā). With the development of Brahman as the "immutable and eternal ground of the universe" the Brahmins, or priestly caste, who claimed to be the connection between the 'eternal dharma' that invisibly is, and the dharma on earth, gained supremacy over the kșatriyas. Brahman later took on a more general meaning of 'sacred power' - it is the fine essence that pervades the entire universe. Brahman is omnipresent and immortal, and man himself is the 'city of Brahman' (See Zaehner 48). Brahman is therefore, loosely, God, existence, consciousness, bliss and peace (ananda) (Isherwood 2). The individual soul (ätman) is synthesised with Brahman - the attman is the God immanent, and Brahman is the God transcendental. The Upanișads "identify the deepest level of the subjective 'I' with the ground of the objective universe" (Zaehner 49). Brahman is therefore not only the "Great Self" present in a timeless reality, but it is also the individual self once it is liberated from its mortal bonds (Zaehner 125). Zaehner summarises the whole teaching of the Upanișads thusly: "it is the recognition within the human soul of an immortal something that participates in, is of the same nature as, or is actually identical with the immortal Brahman which sustains and ensouls the entire objective cosmos" (50). Matter and spirit, the formed and the unformed, the mortal and immortal, the manifest and the unmanifest, the here-and-now and the beyond are both 
intertwined and independent. "The world-process itself is grounded in the deathless, and matter, thereby has itself an infinite and immortal dimension" (Zaehner 51).

There are many implications and conclusions by which Hinduism further explains this relationship between the divine and man. One proposition is that the universe which we perceive by our senses is only an appearance. This outward aspect of the world is constantly changing. However, beneath this appearance is Brahman - and this reality is unchanging. Brahman is undetectable by scientific methods which rely on senseperception but Brahman is omnipresent, and is within each creature and each object - it is our real, essential nature (Isherwood 1). We try to realise the atman and hence our relationship with Brahman, because we realise the incompleteness of our nature in the physical plane. Like many religious traditions, Hinduism acknowledges that the pleasures and riches of this world are fleeting. However, while earthly desires are not condemned, they are seen as ineffectual in the realisation of our divine nature. Unlike earthly desires which cease at death, realisation of our essential nature offers a lasting strength, wisdom, peace and happiness. The way to realise this essential nature is to cease being ourselves. We prioritise the physical self because of ignorance.

Vedānta teaches that the universe is consistent with Brahman, beginningless and endless. Even if apparently destroyed, it will still have a potentiality to re-emerge in due time. The stuff of this universe is an effect or power of Brahman. Brahman does not interfere in the affairs of the world. Unlike the anthropomorphising of God which occurs in Christian conceptions of God, Brahman is not human and he does not punish, or reward, or cause good or evil, nor loves or hates, nor is the source of morality or the ideas of good or evil. Brahman just is (Isherwood 4-5, Klostermaier 416). The radical 
anthropomorphising of God in Christianity was described as to contributing to its belligerence. Perhaps the lack of such anthropomorphising in Hinduism contributes to its peacefulness.

\section{Karma and Mokṣa}

The hypotheses of karma and reincarnation are used to explain what happens to those who do not attain mokșa. Karma means action, work or deed and is "[n]ot only physical action, conscious or reflex, but also mental action, conscious or subconscious" (Isherwood 11). It is the law of causation "which is said to operate in the physical, mental and moral spheres of our lives" (Isherwood 11). Every action produces an effect, and every action leaves an impression upon the mind which gives rise to our tendencies. There are potentially three explanations for the inequalities of the world. The first and simplest is that it is by chance, by heredity and environmental situations. The second is that everyone will be judged and rewarded or punished in the afterlife depending on the use of the talents given to them, and whether these have been used to their full extent. The third answer is that our actions in this life will condition the circumstances of existence in the next.

There is potential for thousands of lives, both on earth and elsewhere. It is not God that binds one man and frees the other, but it is man himself because of his past actions in previous lives. We cannot remember our past lives because birth is a terrible shock which causes us to suffer a kind of amnesia. The law of karma was and always will be in operation, much as the universe is beginningless and endless (Isherwood 14). Escaping karma comes in realisation of the ätman, which is not subject to reincarnation 
and stands beyond karma. When mokșa is attained, the individual ego will cease to exist. When all individuals have attained mokṣa, the ego-sense of inanimate matter, plants and animals will continue to work its way up through human forms and consciousness. Happiness or suffering are waves of thought which arise in the mind, and it is egoism that causes us to identify ourselves with the mind rather than the spirit, or Self. Egoism causes a desire for pleasurable sensory and emotional experiences, and we become attached to these experiences, and attachment causes suffering. To seek pure tranquillity of mind and heart, we must seek a detachment from these experiences. Detachment does not, however, mean aversion, because aversion is also another cause of suffering. One cannot withdraw from the senses, but one must cultivate instead a "right attitude of mind in freeing itself [the mind] from both attraction and aversion" (Prabhavananda 49). The final obstruction which causes suffering is the fear of death (or clinging to life).

The ideas of karma and mokșa began to emerge in Hinduism between the eighth and fourth centuries BCE, a period called the axial age. During this time, great changes took place in the religious life of all people as traditional religion was slowly modified by new ideas to produce today's modern religious and philosophical systems. In India, this marked a

real turning point in the spiritual and intellectual life of the land; it saw the virtual beginning of such typical aspects of Indian religion as the doctrines of transmigration and nonviolence, organized asceticism, mystical gnosis in search or release (mokșa) from the cycle of birth and death, and many lesser features of Hinduism, not to speak of the rise of heterodoxies such as Buddhism and Jainism. (Basham 37)

Many of these new movements were antiritualistic and completely rejected the teachings of the Vedas and the sacrificial cult that the Vedas taught, as well as the authority of the Brahmins who maintained these sacrifices (Basham 59). The rise in asceticism - which, 
in earlier times was confined to the practice of elderly hermits (vänaprastha) living in forests, but which now also includes the wanderer (parivrājaka) - may have been due to a loss of faith in the old truths, dissatisfaction with the current situation and fear of the future (Basham 52). Therefore, many people left their homes, and abandoned society with the hope of finding peace of mind and discovering the secrets of the cosmos and obtaining security in the other world. It was from these ascetics that the doctrine of samsāra and karma developed (Basham 41). The transmigration of souls, or the doctrine of rebirth and reincarnation is central to Hindu thought, but, once again, it is a later development found in the Upanișadic texts rather than the Rg-Veda. Karma also means "act" or "action" in a more general sense. Each of the Hindu castes have acts appropriate to them. All actions are seen as producing either good or evil consequences to the doer, and evil actions result in rebirth in a lower caste or as a lower-than-human life form (Zaehner 59). Thus, there is an unending cycle of cause and effect, of birth and rebirth. This doctrine of karma is thus offered as an explanation of (and justification for) the inequalities of birth and the cause of suffering. The cycle is perpetuated by the thirst (tanha) or craving of the individual, and it is essentially unpleasant and painful (dukkha) (Basham 60).

The consequences of this are as follows. Firstly, this doctrine acknowledges the immortality of the soul, and that the realm of the soul is one outside of space and time. Secondly, it implies that the connection between the immaterial (the soul) and the material (the world/the body) is transient, in constant flux (samsāra), and in some sense unreal. Life is "endless, pointless, senseless repetitiveness" (Zaehner 61) unless one can break the cycle and achieve mokșa (liberation, freedom, release), which is equated with 
reconnecting with Brahman. Thirdly, this creates a sense of time that is not linear. As

Zaehner explains:

For the Hindus the world was not created once for all, nor was there any end to it: from all eternity it had been recreating itself and dissolving back into its unformed and 'unmanifest' condition, and these periods of evolution and devolution were called days and nights of Brahmā. Each day and night of Brahmā lasts one thousand years of the gods, and each year of the gods corresponds to twelve thousand years of men. [...] Such is the Hindu concept of the cosmos - beginninglessness and endless in time as well as in space - and the soul of man must ever anew embark on this journey that has no end, passing from one life and from one body into another [...]. $(61-62)^{78}$

Unlike Christianity, salvation (mokșa) is not salvation from moral guilt, but liberation from the human condition - "it is liberation from space and time, and the felt experience of immortality" (Zaehner 138). Mokșa results in transcendence and finding the true self; it is sat-cit-ānanda - being, consciousness, and bliss which transcends the three legitimate goals of life of käma, artha, and dharma - desire, acquisition of wealth, and pursuit of righteousness (Zaehner 63). The highest goal is dharma (Zaehner 114).

\footnotetext{
${ }^{78}$ Hinduism employs units of time that seem unfathomable to Christianity, especially when one considers certain branches of Christianity and Judaism, which, through a literal interpretation of scripture, paint a picture of the Earth and all it contains as being created 6,000 years ago. Hinduism conceives of a large unit of time, the mahayuga or great age, which itself consists of four successive ages (yugas) beginning with an Age of Truth or Golden Age (Krita or Satya Yuga) which lasts 1,728,000 years, followed by a Silver Age (Treta Yuga) which lasts 1,296,000 years, a Bronze Age (Dvapara Yuga) which lasts 864,000 years and a final Iron Age or Age of Corruption (Kali Yuga) which lasts 432,000 years. We are currently in the Age of Kali Yuga. Each Mahayuga, equals 12,000 god-years, each of which lasts 360 human years, for a total of $4,320,000,000$ human years. In each yuga, there is a progressive decline in human stature, longevity, and morality. One thousand Mahayugas, or cycles of four Yugas, make up a kalpa (eon). Each kalpa is followed by a time of calamity and disaster, on the Earth and in all the worlds. All beings perish. Fire overtakes all of the worlds, followed by a massive flood. Finally all the elements return to the seed of primordial nature, or prakrti, and time itself ends, only to re-emerge when the cosmic night has ended. Within these cycles is another classification of time called the Manvantara, each of which is ruled by a Manu, or "first man," the progenitor of the human race in that period. Because the universe dissolves and reappears again and again, there are an infinite number of such figures. Each kalpa sees 14 Manus reign in succession. This means that a manvantara takes up approximately 71 Yugas. One manvantara thus lasts 367,020,000 years. Each manvantara has seven rssis, certain deities, an Indra, and a Manu. The Manu of our era is known as Vaivasvata. He is the seventh Manu of our kalpa, or eon. We are currently in the Kali Yuga, but there is no agreement among the sources as to precisely where we are in this 432,000-year cycle and when this age will end (Jones and Ryan 447).
} 


\section{Bhakti}

The word bhakti derives from the root bhaj- which can mean "to share or participate in" (Zaehner 93), and in the Bhagavad Gītā, the god Kṛ̣ṇa actively participates in advising his friend Arjuna in battle. The term can be translated as "loyal devotion" or "loving devotion" (Zaehner 126) and is used for a type of religion that emerged in the Dravidian South that ultimately transformed the face of Hinduism. Bhakti movements also gained ground as a response to the invasion by Muslim Turks towards the end of the first millennium CE, and Zaehner describes these movements as the equivalent of the Protestant Reformation in Europe, since amongst other changes, there was a change to using vernacular languages rather than Sanskrit in the liturgy and hymns (136-38).

In the Bhagavad Gìtā, there are three paths to the Absolute and to moksa: the path of knowledge (jñana), the path of action (karma), and the path of devotion (bhakti). Knowledge is not simply learning of texts, but an "intuitive apprehension of Brahman" (Zaehner 126). Karma does not mean the active life alone (divorced from the life of contemplation) and the zealous performance of one's dharma is not in and of itself sufficient for mokṣa, for actions bring their own rewards or punishments, and this itself creates attachment. Mokșa relies on detachment, and transcending good and evil. Knowledge and action are therefore similar. I will discuss the path of action in greater detail when I examine Kṛṣna’s sermon to Arjuna later in this chapter. Devotion is different and it relies on concentrating on God "as being the external exemplar of the liberated soul" (Zaehner 126), and the soul is aided actively to liberation by the grace of God. There is a notion of complete passivity that is required of the individual in order to 
receive God's inflowing grace. This kind of devotion is like that of the Christian mystics St. Teresa and St. John of the Cross (Zaehner 129). This is even more apparent when one examines the philosophies of the Tamil Śaivite saints, a particular bhakti cult that paints a picture of man, as he exists apart from God, as being evil, corrupt and a slave of his egoism (ānava). Therefore, rather than the notions of renunciation and self-forgetfulness, there is now a self-abandonment to God (Zaehner 132-34).

The bhakti movements caused a re-evaluation of the religious experience and a move away from ritualism and the pursuit of a solitary mokșa to an attempt to understand a God outside the soul, or to God as the lover of the soul. Hindu social structures and the caste system were questioned and deemed unjust because they created divisions between men. These bhakti movements believed that God had an equal love for all his creatures, and that salvation was available for all despite creed or caste. However, it was the British and their Christianity-based ideas that would ultimately be the death knell of strict adherence to the caste system and some of the inhuman practices that the caste system had produced, such as the burning of widows (satī), child marriages, enforced widowhood, temple prostitution as well as inequalities and the problem of untouchability (see Zaehner 146-49).

\section{Philosophy and Theology: Indian v. Western}

Hindu philosophy is not a static doctrine, but a growing tradition rich in diverse philosophical perspectives. The work of traditional Hindu thinkers would only be partially recognised as philosophy by Western thinkers. Similarly, the term "theology" also emphasises the exegetical nature of Hindu thought, since some schools of Hinduism 
are atheistic (Flood 224). The terms for "philosophy" or "theology" are both translated as darśana - which focuses on commentaries on the fundamental texts, and ānvīkșiki, which is analysis or 'investigative science' within the field of Vedic knowledge, particularly with reference to logic (nyāya). Darśana means view, vision, comprehension, point of view, or doctrine, and is derived from the root $d r \underline{s}$ meaning to see, to contemplate, to comprehend (Eliade 6). The general features of orthodox (āstika) Hindu darśanas - (as opposed to the heterodox (nāstika) views of Jainism, Buddhism and Materialism (Cārvākas or Lokāyata) - are summarised by Flood thusly:

1. Assume the revelation of the Veda;

2. Claim to have liberation (moks $a$ ) as their purpose;

3. Are exegetical in nature, being expressed primarily through commentaries and sub-commentaries on revelation (the Upanișads) and on primary texts called Sütras, which form the scriptural source of philosophical/theological schools;

4. Assume a transcendental reality beyond the contingencies of the human condition;

5. Offer systematic explanations and interpretations;

6. Are concerned with ideas about the structure of the body, the nature of matter and the functioning of consciousness. (225)

In addition to the subsuming of "theology", there are other contrasts between the Sanskrit term darśana and the Greek term philosophia. Philosophia is the love of wisdom, "an eros which by its nature generates ceaseless inquiry and search aiming at wisdom" (Mohanty 8). It is the individual thinker, captivated by philosophia that plays a decisive role. Darśana, however, is "systematic elaboration of truth, or an aspect of it, which has already been grasped; it is not search for truth but exposition of it, intellectual vindication, conceptual fixation, and clarification of what has been received" (Mohanty 8). The individual thinker plays no decisive part in founding systems, but rather promulgates explanations. Indian philosophy, rather than conceiving of itself as man's 
historically developing understanding of self and the world, regards itself as an objective body of knowledge about the nature of things (Mohanty 18). While Western thought separated, (or as Mohanty describes, "emancipated") science from philosophy, this is not true in the darśanas. Unlike Aristotelian philosophy, there was no distinction between physics and metaphysics ((Mohanty 18). As the Indian Supreme Court stated in Yagnapurushadji, "unlike other countries, India can claim that philosophy in ancient India was not an auxiliary to any other science or art, but always held a prominent position of independence" (262). This demonstrates that Hindu political writings are well steeped in the religious worldview of Hinduism. There are never distinctions between theology and philosophy. Therefore, there was never a need to divorce religion from politics, as there was in the post-Enlightenment West that looked to ideas of natural law in order to formulate doctrines of statecraft. Modern philosophers tend to cast Greek philosophy as separating theory from practice, and of being separated from mythology (and also theology, literature and the natural sciences). However, Indian and Chinese philosophy is not cast as making this same separation. It is perhaps for this reason that, consequently, the Greek philosophic traditions came to be valued, and the Indian (and other Eastern traditions) were disregarded or romanticised as an oriental, mystical mode of thinking (see Mohanty 284-85).

Another difference from Western philosophy is that accurate dating and assigning authorship of classical texts is almost impossible because most writings were in the third person, and presented as the ideas of earlier writers. In addition, almost nothing is known about Kauțilya or Manu, and some even doubt if these individuals existed. However, in darśana, the individual is not important - they are just recording the truth from God. 
Dating is further made impossible because Sanskrit texts were transmitted orally until the sixteenth century (Roy, Ethics of Warfare 7). It must also perhaps be noted that unlike Western philosophers, Hindu texts are meant to reflect an elite (read: Brahmin) ideology and describe the world as it should be rather than as it is (Roy, Ethics of Warfare 8).

\section{Māyā: An Experience of the World}

Another Vedic idea that deals with the way the world is experienced is the concept of $m \bar{a} y \bar{a}-$ supernatural power or illusory experience that makes us believe that the phenomenal world is real. This binds man to rebirth and re-death in a transient and miserable world (Zaehner 33). The idea of $m \bar{a} y \bar{a}$ has two results in terms of sociopsychological analysis. The first is a trend towards other-worldliness and a withdrawal from the world because what one can perceive with the senses and intellect is understood as only an external superficial experience of reality that hides a deeper, hidden "real" reality. The second is the opposite - a trend to engage in the world. There is a sacramental perception and understanding of reality in which everything is an expression of the divine oneness. Nothing in this world is to be devalued but, everything should be experienced and engaged with in all possible ways. Von Brück explains: "It is this tension between other-worldliness or asceticism and the perception of the whole of reality as divine, that marks the special flavour of Hinduism and a number of other Asian cultures. What Hinduism derives from it is its synthetic power to integrate and transform all cultural difference and place them into this cultural context" (13). India has had many invaders, however, and without exception, India has integrated ideas and beliefs from its invaders and adopted these customs as their own. Also, without exception, those who 
stayed in India were themselves integrated, subsumed and transformed, and those, like the British, who left transformed their own countries. Ideas of integration and synthesis of ideas from outside seems in great contrast to the Christian ideas of having a monopoly on Truth claims. The Christian idea only results in intolerance, and provides the justification to enter into war as Christian soldiers are seen to be defending the truth and what is right.

\section{Time, History and Historicity}

From the Jewish and Christian traditions, two components emerged which superseded earlier conceptions found in antiquity. One was the idea of creation out of nothing, and the second was the concept of a linear temporal order - the latter results in a teleological view of the world that is heading towards the second coming of Christ. The first idea, may prima facie be theological, but it does influence all aspects of thinking. For example, Western logic and metaphysics developed the idea of pure possibilities as prior to the actual world. The second idea, may prima facie be secular, but relies on theological explanations. This creates a unique point of origin and an eschatological world-view (Mohanty 18-19). Indian thought lacks both components: its conception of time has no starting point and is neither eschatological nor teleological.

Mohanty states that "no Indian philosopher accorded to time that central place in ontology which modern Western philosophy has" (184). However, he dismisses the commonly held concept of the Hindu idea of time as unreal or illusory. He also dismisses the view of time in Hindu philosophy as being cyclical, in contrast to the linear notion of time in Judeo-Christian thought. He acknowledges, however, that there may be 
different views of time within the systems of Indian philosophy. According to the most influential school, Advaita Vedānta time is unreal in a deep metaphysical sense, however, he notes that in this system, the concepts of space and causality, inter alia, are also metaphysically unreal. ${ }^{79}$ He cites Vedānta scholars who use terms such as 'past', 'present' and 'future' in their definitions of time, and Patañjali, the compiler of the YogaSūtras who states that "time is that because of which growth (upacaya) and decay (apachaya) of things are to be noticed" (186). Frederick Kumar states that it would be a mistake to conclude that early Indian philosophers had no concept of time and the reason their thinking has the character of a universality unconditioned by chronological time is because "[t]he attitude reflected in the language and logic of the thinkers seem to show that they did not want to confine their thinking to a particular society nor did they want to confine their thinking to a specific period or race" (14). He notes however that contemporary and near contemporary Indian authors do specifically record time.

Regarding the concept of time as cyclical, Mohanty says that the theory of cyclical changes, that is, the cycle of creation and dissolution, of happiness and suffering, and the cycles of birth, death and rebirth that are found in Hindu and Buddhist religious and mythological texts should not be confused with a theory of time itself as cyclical. As he explains, "[i]f these cycles succeed each other, such succession requires a non-cyclic time" (186). The representation of time as infinite (beginningless and endless or anāndi and anainta) does not imply a cyclic nature of time. The idea of epochs (yuga) may be a way of determining units of cosmic time, and do present the idea of recurring ideas and

\footnotetext{
${ }^{79}$ There seems, therefore, to be a distinction between metaphysical time and experienced time. The concept of cyclical time applies, according to some schools, only to metaphysical time, and the ideas presented indicate that a sense of progress, or history is just as present in Indian philosophy as in the West.
} 
values (similar to theories in modern economics of cycles of inflation and recession), however, they do not equate to a case of cyclic time or of eternal recurrence (187).

In Hinduism, and other religious, there is a distinction between sacred time (of religious mythologies, cosmic time) and profane time (of natural and historic order). Sacred time is cyclical, and it is the cyclical nature of sacred time which provides the foundation for profane time, for example in the re-enactment of religious rites. For example, the Jewish and Christian liturgical calendars revolve around a retelling of the sacred histories of their people, of the celebration of feasts (Christmas, Passover, Easter, etc.) in an unending and continuing cycle. ${ }^{80}$ In the same way, Hinduism views sacred time as an unending and continuing cycle. However, profane time is not sacred. Mohanty doubts that anyone held a conception of time as cyclical or unreal (190).

Reflecting on the Indian philosophical concern with history, such a concern appears to be lacking, since none of the Indian schools of philosophy recognised "historical knowledge as an irreducible variety of true cognition (pramā) or as caused by a distinct sort of means of true cognition (pramāna) (Mohanty 188). However, it is only in modern times that Western thought considered history seriously, despite the historicity of Judeo-Christian self-understanding. Classical Greek thought was also ahistorical. The Sanskrit equivalent to history - itihassa - is far more all-encompassing than the English "history" and means "arranged in the form of stories and past happenings, conveying instruction in dharma, artha, kāma, and mokșa." It also encompasses the tales from the past (purānas), dynastic chronicles (itivrtta), short tales (ākhyāyikā), exemplary stories

\footnotetext{
${ }^{80}$ Yogānanda explains that even in the Hebrew Bible, time is often allegorised. For example, he points out that the crossing of the Sinai in the Exodus could not have possibly have been a literal forty-year account but that "[t]he time can only have been so stated deliberately in order to suggest a deeper meaning behind the quest for the Promised Land" (Yogānanda 15).
} 
(udāharaṇa), laws (dharmaśāstra), political economy (arthaśāstra), philosophy, cosmography, and genealogy of sages and gods (Mohanty 188). Therefore, sacred history, profane history, biographies, narratives, fables, mythology, philosophy and science all appear to fall under the rubric of itihāsa. From this list, it can be gleaned that there is an idea of historicity, but the idea of the importance of history is missing. If philosophy is concerned with ageless, eternal truths and values, however, the need for a concern with history also disappears. Mokșa (or mukti) involves escaping historicity, and the transmigration of souls is not reflective of the history of an individual soul, but rather the gradual advance of social groups, of humankind towards a goal. "The history of man is the history of human consciousness. What is needed for a sense of history is a recognition of the historicity of consciousness" (Mohanty 190).

It is with this idea of time in mind that literal interpretations of Scripture in Hinduism become much more difficult to subscribe to in contrast to literal interpretations of the Bible in Christianity. If time is linear, and Christians view the Bible as containing actual historical accounts of events, many Christians await an end, and equate this end with the end of suffering and the end of war when Jesus comes to judge the world. There is even evidence that many Christians support pro-Zionist political goals because they believe that the land of Israel being returned to the Jews is a sign of the end times and will usher in the Second Coming of Christ. ${ }^{81}$ However, from a Hindu perspective, there is not as much emphasis on teleology, since there is less emphasis on history. There will be less emphasis in seeing the history of various wars as eventually leading to a certain divinely ordained political status, and therefore a reduced possibility of characterising

\footnotetext{
${ }^{81}$ See Grace Halsell, Prophecy and Politics: The Secret Alliance between Israel and the U.S. Christian Right, Chicago: Lawrence Hill and Co., 1989.
} 
certain wars as divinely ordained. Christian teleology stems from an eschatological view of history; Hindu teleology stems from mythical history that envisions the recurring return of the incarnate god (vyūhas and avatāras such as Kṛ̣na or Viṣnu). However, there is no idea of an end of history, since the view of history is not one of chronicling the achievements of man and men; but there is an idea of developments of stages of consciousness of mankind, and eventually, mokṣa is the telos of individual souls.

\section{Systematic Hindu Philosophies (Darśanas): Different Theologies, Different Ontologies, Different Epistemologies}

Hindu theologies are also interested in the relation between this world and the world beyond mortal existence. Hindu revelation refers to the idea of an absolute, unitary reality contrasted with existence in this world as manifold and diverse. However, different theologies view the relationship between the otherworldly and the worldly in different ways. Some of these philosophies are theistic while others are atheistic. Some affirm the authority and importance of the Vedas, and others do not. Hindu philosophers, for instance, do not agree as to whether God is a person. Some recognise the final end of the Self as mokṣa, others do not. While all Hindu philosophers hold that there is something like an individual self, they differ radically in their account of the reality and nature of this individual. Some maintain that the absolute is ultimately identical to the worldly diversity, and that differences are merely illusory. Others maintain that there is a difference between the two. This question of being, which is related to the epistemological question of causation, has two main philosophical viewpoints. The satkāryavāda theory maintains that the effect is pre-existent in the cause, as a pot (the 
effect) pre-exists in the clay (the material cause). (This theory can itself be divided into parinama, which maintains that the effect is a real transformation of the cause (found in the Sāmkhya school), and vivarta, which maintains that the effect is not a transformation of but a mere appearance of the cause, found in the Advaita tradition, which holds that Brahman is the only substance in reality.) The asatkāryavāda theory maintains that the effect does not pre-exist in the cause, and can be found in Buddhist thought (Flood 230).

The six orthodox intellectual traditions of Hindu philosophy (saddarśanas) became codified in the medieval period. Any detailed analysis of these traditions is beyond the scope of this dissertation; however, I believe that some detail is required to show how the ideas of the most influential system today, Vedānta, have been shaped by the philosophies of the other schools. Radhakrishnan states that of the six orthodox schools, "the Vaiśeșika is not very much in honour, while the Nyāya on its logical side is popular and finds many devotees, especially in Bengal. The Yoga in its practical form is practised by a few, while the Pūrva Mīmāmsā is closely related to Hindu law. The Sāmkhya is not a living faith, while the Vedānta in its different forms pervades the whole atmosphere" (Radhakrishnan, Indian Philosophy 28). Because of its popularity and influence, I will be focussing more closely on the Vedānta school, specifically the Advaita Vedānta. The other schools of Vedānta are the Viśiștādvaita, which can be translated as "qualified non-dualism" or "non-duality of the qualified whole" or "nonduality with qualifications", and the Dvaita or "dualist" school. 


\section{Advaita Vedānta: Modern Hindu Philosophy}

The theology of Vedānta, or discourse/exegesis on the Vedas, forms the philosophical basis of the Hindu renaissance in the nineteenth century and has shaped Hinduism as a modern world religion (see Isherwood 1). I will, therefore, offer a more detailed explanation of the ontology of this system which will later be used as a basis for an examination of the question of war. Vedānta has some continuities with the Mīmāmsa tradition. While the Pūrva Mīmāmsā concerns itself with explicating the former portion of the Vedas, the Vedānta school concerns the end (anta) of the Vedas. Whereas the principal concern of the earlier portion of the Vedas is action and dharma, the principal concern of the latter portion of the Vedas is knowledge of Brahman - the investigation of the absolute (athāto brahma-jijñasa) and mokșa. There are also some theological continuities with the Vaiṣnava tradition. Although the Vedānta philosophy has different schools of thought, one of the unifying ideas in Vedānta is the primacy of the individual's quest for truth through meditation governed by a loving morality over ritual action. Nearly all existing sects of Hinduism are directly or indirectly influenced by the thought systems developed by Vedāntic thinkers (see Flood 238-39). The broad concepts which the Indian Supreme Court used to define Hinduism in Yagnapurushadji have their basis in the elements of Vedānta (see Ishwerood 1-14).

All of the three major schools of Vedānta hold that the Vedas are the ultimate source of knowledge of Brahman, and that the Vedas have an independent validity, not reducible or contingent upon the validity of any other means of knowledge. For these schools, natural reason cannot, on its own, arrive at knowledge of the existence of God (Brahman). Vedānta views the individual soul (jīva) as being uncreated, and having no 
beginning, although some regard Brahman as the source of individual souls. The individual, or $j \bar{\imath} v a$, is recognized as an eternal agent with desires and goals, although the individual is powerless to make its will manifest. Brahman steps in and grants the fruits of the desires of an individual. Brahman's help in bringing about the fruits of desires of individuals implicates Brahman in the evils of the world, but Brahman is not responsible for evil or for forcing individual action, since there is always some prior choice and action on the part of the individual (see Śankkara's Brahma Sūtra Bhāṣyas II.iii.16, I.iii.41, Rāmānuja’s Brahma Sūtra Bhāṣyas II.iii.18, II.i.34; I.iii.41, Madhva Bhāṣya II.iii.19, II.i.35, II.iii.42).

Advaita Vedānta is the most famous school of Indian philosophy, and it is often mistaken as the only school (Flood 239), although many view it as an elitist school and not one to which the majority of the population subscribes. The term 'advaita' is often translated as non-dualist, non-secondness, or monist, which is due to the recognition that Brahman is one without a second. ${ }^{82}$ The most famous Advaita thinker is Śankara or Śañkarācārya who lived between circa 778 and $820 \mathrm{CE}$ and wrote commentaries (bhāṣya) on the Brahma Sūtra, the Bṛhadāraṇyaka and Taittirīya Upanișads, and on the Bhagavad Gītà as well as other influential texts. Śankara develops a theology that argues that spiritual ignorance (avidyā) or illusion $(m \bar{a} y \bar{a})$ is caused by the superimposition $(a d h y \bar{a} s a)$ of what is not the self onto the Self ${ }^{83}$ through subjectivity (consciousness, or the sense of being a witness (cit)). In other words, adhyāsa falsifies knowledge in a way that the subject is unable to find objective truth. All sense perception is thus

\footnotetext{
${ }^{82}$ Note that the terms 'advaita' and 'dvaita' respectively are not synonymous with Christian conceptions of "monist" and "dualist" (Klostermaier 413).

${ }^{83}$ In this section especially, letter cases are important as I denote the differences between the material subjective self as a small 's' self, whereas the spiritual consciousness as a capital 's' Self.
} 
questionable, and possibly misleading owing to preconceived, superimposed ideas. The lower self, or $j \bar{\imath} v \bar{a}$, is what we attribute to the body, a unique personal history, and that we distinguish from other persons and objects. This results in a distortion of knowledge (through rational thought or manas), which prevents us from knowing our true nature (atman) which is identical with the Absolute (Brahman). Even the gods are merely temporal representations of Brahman. The world of objects, however, is not merely an illusion: it is neither nonexistence (abhāva) nor emptiness (śünyatā) (Klostermaier 416). Discrimination must be developed in order to recognise this connection between our subjective selves and the objective Self (ätman) which is connected to the Absolute. The removal of this superimposition, the non-identification of the Self with a body, or a particular person with a natural history is the achievement of liberation (mokșa). Therefore, what we view as the plurality of objects and persons is ultimately a false reality. The only reality is Brahman: objects of its awareness, such as the entire universe, exist within the realm of its consciousness. The great sayings (mahāvākya) or supreme secrets (paramam guhyam) of the Upanișads exemplify this monist thinking: 'I am the absolute' (ayam ätmā brahma); 'everything is indeed the absolute' (sarvam khalu idam brahma); and 'that thou art' (tat tvam āsi) (Flood 242, Kumar 40).

This idea of spiritual ignorance is Hinduism's answer to the Fall. Rather than saying that conflict in the world is the result of sin, and that sin is the result of man disobeying God, conflict in the world is said to arise out of ignorance of the nature of the true Self. This kind of description of self is very different from a Christian perspective. It seems to define not only humanity but all of creation as a whole, surpassing tribal and creedal differences. The idea of being a "chosen people" seems out of the question, as 
everyone is viewed as part of the same absolute (notwithstanding the differences in caste that originally demarcated divisions of labour and responsibilities in society rather than an ontological hierarchy of people). This mentality might serve to reduce the violence in warfare.

The emphasis in Advaita Vedānta is on jñana or knowledge. Śankara does incorporate the act of devotion (bhakti) as a lower level of knowledge, recognising a temporal aspect to Brahman. Like the differences between the lower self $(j \bar{\imath} v \bar{a})$ and higher Self (ātman), he also distinguishes between a lower and a higher Brahman (Śañkara Brahma Sūtra Bhāṣya IV.3.16). The lower Brahman is the personal God that pious devotees pray to and meditate on which has attributes (saguna Brahman), while the higher Brahman, beyond all predicates and qualities (nirguna Brahman), is impersonal, and is characterised as being essentially bliss (ānanda) (Śañkara Brahma Sūtra Bhāṣya III.3.14) truth (satyam) knowledge (jñanam) and infinite (anantam) (cf. Śankara, Taittirīya Upaniṣad Bhāṣya II.i.1). When reading the Vedas, Śankara taught that these two levels of Brahman were two levels of truth in operation (Flood 243). Unlike Christianity, which emphasises devotions (e.g. Catholic Masses, rosaries, litanies, novenas, or even, ostensibly the Crusades) and faith (in Jesus and salvation by his death on the cross), Vedānta stresses knowledge of the self and knowledge of God viewing devotion alone as a lower level of knowledge.

Even dharma is not as important in Advaita philosophy. Śankara takes a sceptical attitude towards the importance of dharma saying that the Vedic injunctions on dharma should only be followed if one cannot realise the oneness of the self with the true Self, and its connection to Brahman, for the Vedas will help form introspective tendencies and 
aid in ultimate liberation. However, for the serious aspirant, dharma itself is an impediment to liberation and must be abandoned, in order to prevent the identification with a self in contradistinction to other objects and persons (Śankkara, Bhagavad Gītāa Bhāsya 18:66, 4:21). In prioritising obtaining mokșa to following dharma, tasks such as soldiering or ruling seem pointless as it is introspection and not worldly actions that ultimately lead to mokșa.

Now that I have explored how some of the concepts of Hinduism differ from Christianity, and how some of these might impact Hindu thinking on warfare, the Bhagavad Gîtā will be examined in more detail to determine how this text has been interpreted with respect to the justification of warfare.

\section{Background story of Bhagavad Gītā}

In order to understand the context of the eighteen-chapter, seven-hundred verse long Bhagavad Gìtā, one must turn to the lengthier and highly symbolic epic, the almost one hundred thousand verse long Mahābhārata, which the Bhagavad Gītā forms part of. While the war setting in the Gîtā is said by many to be allegorical, it is also viewed as partly historical. Tradition holds that the war took place about 3000 BCE (although, historically, it may date to around 1000 BCE (Basham 73). However, most Hindu philosophers approach the text as allegorical rather than a reporting of an actual historic event. These teachers even point out that the spot in modern India today where the battle is commemorated is too small for a battle of over 1.6 billion people (see Tripurari 210). The first śloka of the text itself favours an allegoric reading of as it describes the battlefield where the war is taking place (Kurukșetra) as Dharmakșetra - the field of 
dharma, of duty and righteousness, perhaps implying that the Gìtā's teachings are meant to transcend an actual battlefield (Rosen 12). Yogānanda states that the main characters of the Gītà (the Pāṇdava brothers, some of the Kauravas and a number of others) did live historically, but that the rest of the characters were fictionalised by Vyāsa, the compiler of the text who "presented episodes in their lives in such a way as to conform to the allegory he was weaving like a tapestry" (13). These lesser characters represent psychological qualities in man (Yogānanda 21).

\section{A Synopsis of the Main Plot of Mahābhārata ${ }^{84}$}

The war described in Mahābhārata is the result of a familial dispute between two sets of cousins - the Pāṇdavas and the Kauravas. The Pāṇdavas were five brothers, who were said to have been born as a result of blessings of specific deities: the eldest Yudhișthira (from Yama, the god of death who passes judgement when a soul dies); Bhīma (from Vayu, the wind god); Arjuna (from Indra, the king of heaven, and also the warrior-God); and, Nakula and Sahadeva from invoking the twin deities, the Ashvins (the physicians in Heaven). The five brothers all had a common wife, Draupadī. The Kauravas were one-hundered brothers, the eldest of who was Duryodhana - who is seen as the Kālì Puruṣa - the demon Kālī in human form (Rosen 15). The five Pāṇuava princes and the one hundred Kaurava sons were raised and educated together as kșatriyas, receiving the tutelage of their preceptor Droṇācārya, said to be the greatest warrior of his time. Arjuna excelled above all of them in archery, and he was also a moral and ethical

\footnotetext{
${ }^{84}$ Some of this summary is an abbreviated version of the summary of Swami Dharmānanda in Chapter 6 of his book Advance [sic] Yoga Study: The Science of Yoga, Ayurveda, Tantra, Vedanta Indian Spirituality, Phylosophy [sic], Religious and Social Traditions $<\mathrm{http}: / /$ www.healthandyoga.com/html/readingroom/ays/ays 177.asp $>$.
} 
person. There was always resentment between the two clans because the father of the Kauravas, Dhṛtarāṣtra, was supposed to be the rightful heir to the throne, but because he was born blind, Pāṇdu was made king, and Yudhișṭhira became the rightful heir, something which Duryodhana resented as he saw himself as the rightful heir.

When Dhṛtarāṣṭra (who was appointed as a proxy ruler until the Pāṇḍavas were old enough the rule) became old and wanted to retire to the forest, although knowing that he had to give the kingdom to Yudhișțira, he resented this idea thinking that his son Duryodhana should be king. Dhṛtarāșțra was in a conflict of duty: his duty as a father was to give the kingdom to his eldest son Duryodhana, although he was only acting king since his brother Pạṇụ had been king. Even as a king, however, his duty was to give the kingdom to the most suitable candidate, who was Yudhișthira. He decided on an alternative and divided the kingdom in two parts and gave one part to his children and the other part to the children of his brother. However, Duryodhana was not happy with this for he desired the whole kingdom. In time, the kingdom of the Pāṇdavas became more prosperous, and this further increased the jealousy of the Kauravas. This is evidenced by the fact that Duryodhana repeatedly tries to kill Bhīma, once feeding him a poisoned cake. He also arranges for a house of lacquer to be built and sets it on fire while the Pāṇḍavas and their mother are inside. Draupadī is even kidnapped. Duryodhana, and his wicked uncle Shakuni, arranged a fraudulent game of dice in which Yudhișțira was defeated and lost his kingdom and also himself and his brothers, and Draupadī. The Pāṇụavas and Draupadī became slaves to their cousins. Duryodhana took over the kingdom of the Pāṇdavas and sent them into exile in the forest for twelve years, after 
which they were to live a thirteenth year incognito. If they survived this thirteen-year ordeal, they could return and once again rule their kingdom.

Under the Kauravas' reign, the country knew only hardship and suffering. During this time, the Kauravas stockpiled weapons, formed alliances with neighbouring countries and increased in military strength at the expense of their subjects whom they overtaxed and whose protection they did not care about (Rosen 16). After thirteen years, the Pāṇdavas, having met all the conditions of their exile, returned and demanded their kingdom, but the Kauravas flatly refused to keep their end of the bargain. Kṛṣna intervened and delivered a message on the right duties of a king to Dhṛtarāșțra, that he should give the kingdom to the most deserving candidate: the eldest, and most deserving of the one hundred and five male cousins was Yudhișțhira and not Duryodhana. Kṛșna, being extremely reasonable, even asked for only five villages, one for each of the brothers, and he said that he would convince the brothers to be satisfied with this, but the Kauravas refused to part with even the smallest part of land that would fit on the head of a pin. Kṛ̣na then informs the king that if the kingdom is not returned, war will be inevitable. The king and Duryodhana did not heed this advice. ${ }^{85}$ It is apparent that Kṛṣna and the Pāṇdavas made several attempts to avoid warfare. Even when Draupadī insists on war to redress the injustices against her husband, Kṛ̣na rebukes her saying that war should never be fought for revenge, personal insults or in anger (Rosen 16). Yudhișțira makes an impassioned plea about avoiding war, which sadly has no effect on the Kauravas:

\footnotetext{
${ }^{85}$ Some scholars say that although Duryodhana recognised that Kṛṣna is God, he hates Kṛșna, and he prefers to do battle, and his father, although knowing that war will bring utter ruin, acquiesces to his proud son and war is declared (Zaehner 107-8, Basham 71). Swami Dharmānanda says that Duryodhana and his father thought that Kṛ̣na was only a magician with no real powers.
} 
War is evil in any guise. What killer is not slain in return? To those who die on the battlefield, victory and defeat are equal... the survivor is also a loser. As time goes on, someone will perhaps kill one of his loved ones, as karma decrees, or he will otherwise regret his violent acts... It is the righteous warriors, truly noble and with a mood of compassion, who are generally killed in war. And the lesser men escape. There is naturally remorse after the killing of others, especially in the hearts of warriors who know the value of life. Only pain can come from battle. (Udyoga-Parvan 70.55-58 qtd. in Rosen 16).

When war became inevitable, Arjuna for the Pāṇdavas and Duryodhana for the Kauravas both sought Kṛ̣ṇa's aid. Kṛṣna stated that one party could have his massive army, and the other side could have himself as a personal counsellor. Arjuna was given first choice because he was the younger of the two and because Kṛṣna saw him first. Arjuna chose Kṛṣna's counsel, while Duryodhana rejoiced to be awarded the army. These choices, between armed battalions and God's grace, appear to be the actual reason for the whole war - not a dispute about land, but a dispute about establishing a Godconscious kingdom, and it is in the context of this choice that Kṛṣna delivers his sermon, or song, to Arjuna (see Rosen 17).

The field of the war was Kurukșetra and Arjuna was initially prepared to fight. However, before fighting could commence, he asked Kṛ̣na to take him to a place in the field where he could see his enemies. He then saw his relatives, and family elders, as well as his teachers, and seeing the huge armies gathered on both sides, Arjuna contemplated the great loss of life and property and was seized with a moral conflict. ${ }^{86}$ He dropped his weapons and decided not to fight. However, Kṛ̣ṇa advises him why he must fight, and this is where the Bhagavad Gītā begins - on the eve of battle. Kṛ̣ṇa takes

\footnotetext{
${ }^{86}$ The reason for this conflict is the clash of duties of Arjuna as a warrior having to fulfil his kșatriyadharma and fulfilling his kuladharma (kinship duty) as part of the family of both sides. "In accordance with kuladharma, Arjuna is not supposed to kill his relatives and clan members who have sided with Duryodhana. But in accordance with kșatriyadharma, Arjuna is supposed to kill his enemies without regard to whether they have any blood relations with him (Roy, Ethics of Warfare 32).
} 
the opportunity not only to give stirring advice to the confused Arjuna but in the process teaches him a philosophy of life and action. After Kṛṣna finished his deliverance, he asked Arjuna to think over and decide what he will do. He was given the free choice to choose what he should do, and Arjuna decided to fight the war, as he realised that at that moment, it was his rightful social and family duty to do so. ${ }^{87}$ He recognises himself as a kșatriya - being a son of Indra, being trained by the great Droṇācārya, and being a natural hunter and warrior since his youth. Therefore, the hesitation is only momentary, but it shows a sensitivity that is human. At the end of the war, it was a victory for the Pāṇḍavas. The five brothers reigned nobly under the kingship of the eldest, Yudhișthira, until at the end of their lives, they retired to the Himalayas and there entered the Heavenly realm.

By looking at the facts, it seems like many justification arise for the war. This war could be viewed as just because it is undertaken to rightfully claim a kingdom, or to fulfil the terms of a contract, for spousal honour, or to protect citizens who were suffering under a despotic Kaurava regime. These are the kinds of "just causes" that might be sufficient to launch a war from a Christian just war perspective. However, this is not what Kṛṣna's sermon to Arjuna discusses (despite the fact that offering protection may be seen as part of the injunction to fulfilling his dharma) because of the concept of motiveless action. I will now examine Kṛṣna's sermon to determine the divine justifications for war as discussed in the Gītā.

\footnotetext{
${ }^{87}$ Note that even though Arjuna is given a choice, there is an idea of predestination in the Gìta as the text says: "Time am I, world-destroying, grown mature, engaged here in subduing the world. Even without thee (thy action), all the warriors standing arrayed in the opposing armies shall cease to be" (BG 11:32-3).
} 


\section{The Bhagavad Gītā and Kṛ̣ṇa’s Sermon to the Warrior}

Kṛ̣na's homily, found from the first chapter to Chapter 2, verse 38, seeks at answering the ethical problem - is warfare justified? Kṛ̣na argues that since killing the body only results in killing what is material, it is not of such grave consequence as the soul continues to live. According to orthodox teaching, when a warrior dies in battle, his soul goes straight to heaven, and therefore Arjuna would actually be doing a service to his kinsmen by ridding them of their bodies. As Kṛ̣ṇa says:

The dweller in the body of every one, O Bhārata (Arjuna), is eternal and can never be slain, Therefore thou shouldst not grieve for any creature. (BG 2.30)

Never was there a time when I was not, nor thou, nor these lords of men, nor will there ever be a time hereafter when we all shall cease to be. As the soul passes in this body through childhood, youth and age, even so is its taking on of another body. The sage is not perplexed by this. (BG 2.12-13)

It is said that these bodies of the eternal embodied (soul) which is indestructible and incomprehensible come to an end. Therefore fight, $\mathrm{O}$ Bhārata (Arjuna). He who thinks that this slays and he who thinks that this is slain; both of them fail to perceive the truth; this one neither slays nor is slain. He is never born, nor does he die at any time, nor having (once) come to be will he again cease to be. He is unborn, eternal, permanent and primeval. He is not slain when the body is slain. (BG 2.18-20)

Just as a person casts off worn-out garments and puts on others that are new, even so does the embodied soul cast off worn-out bodies and take on others that are new. Weapons do not cleave this self, fire does not burn him; waters to not make him wet; nor does the wind make him dry. He is uncleavable. He cannot be burnt. He can be neither wetted nor dried. He is eternal, all-pervading, unchanging and immovable. He is the same for ever. (BG 2.22-24)

For to the one that is born death is certain and certain is birth for the one that has died. Therefore for what is unavoidable, thou shouldst not grieve. $(\text { BG 2.27) })^{88}$

It is worth noting that Kṛṣna's sermon to Arjuna itself, in which bodies are described merely as "worn-out garments" that contain an undying soul, is not sufficient to

\footnotetext{
${ }^{88}$ All quotations from the Bhagavad Gītā are from S. Radhakrishnan's translation.
} 
justify the fighting of a war; it is instead an aid in purging the guilt associated with killing in a war (see Klostermaier 104). It is the appeal to fulfilling his dharma as a kșatriya that has the biggest impact for it is his dharma which specifies what is right and wrong for the warrior; a violation of this duty would bring shame (for he would be accused of cowardice by his enemies), be seen as ignoble (anārya), unmanly, and his conduct would not be conducive to entering svarga (heaven) (see BG 2.33). Therefore, fighting, regardless of the outcome is a win-win situation: if he wins, he will enjoy an earthly kingdom, but if he loses he will attain the heavenly planets (BG 2.37) as long as his fighting is "for the sake of fighting, without considering happiness or distress, loss or gain, victory or defeat" (BG 2.38). Kṛ̣na instructs Arjuna that achieving mokșa in battle is by total dissociation of one's soul, which, by virtue of being eternal, is not responsible for acts committed in the temporal, samsaric, earthly plane by the body which is connected to the temporal and to matter (prakrti) (see Zaehner 94-95). "He will have passed beyond pleasure and pain, the sense of 'I' and 'mine' and all the opposites, for he will understand that since he has his true being outside time and space, he cannot die" (Zaehner 95). Intention in action is important - intention is supposed to be in service of the divine and for no other reason - that is, action should be motiveless.

\section{Motiveless Action: The Crux of the Bhagavad Gītā}

In a section of the Mahābhārata known as the Anugītā, or Secondary Gītā (Book 7, Chapters 16-51), Kṛṣna visits Arjuna in the palace of the Pāṇdavas at which time Arjuna admits that he has forgotten much of Kṛṣna's sermon on the battlefield. Kṛ̣na responds that it is not possible for him to repeat this sermon in full but he continues to 
instruct Arjuna. These later verses introduce theistic conceptions into Hinduism, and also explain the doctrine of motiveless action: we should do whatever we do because it is the right thing to do, and without any regard to personal gain or loss. Therefore, although, as previously stated, there were justifiable reasons for Arjuna to fight, this is not why he ultimately does so. This is the most important teaching of the Bhagavad Gītā - that humans' business is with work and activity, not with results. By thinking of the fruits of action, one's own desire is being expressed, and this expression of self will prevent the integration of the Self and the highest spiritual goal, which is reconnecting with Brahman (see BG 2.47, also Basham 86). In order to achieve this high state (called nirvāna - a state of indescribable calm and bliss (Basham 89), all desires must be subdued and all sense of ego must be lost. All action must ultimately be done for the love and glory of God, thinking of God always (see BG 9.27; 13.55-57). What appears as a senseless fratricide in the story of the Gītā is only so if one has not surrendered the ego. Arjuna's intellect is connected to the finitude of the earth, and not the infinity of eternity, therefore, even if it appears wrong at face value, from a divine perspective, it is not what it appears to be. Arjuna is bound by duty (dharma) to obey it (Zaehner 103).

\section{Yoga - the Path of Motiveless Action}

But how is it possible to act without motivation? Klostermaier paraphrases these words of Kṛ̣na as the gist of the whole Gītā which he claims has influenced practical ethics in India throughout the centuries: a rightful claim extends to actions only, not to results; the fruits of action should not be the motive but also, one should not cling to inaction. Established in yoga, do your work after abandoning attachment, unmoved by 
success or failure (Klostermaier 104). Yoga is a path of neither inaction, nor mere action, but it is action with skill and understanding and is of highest importance in the Bhagavad Gìtà (Eliade 153). Usually, action is always with attachment, such as fear or desire. However, it is attachment which binds us to the material world of appearance, and to samisāra and rebirth into this world. The proper performance of action is in nonattachment, or in Christian terms, "holy indifference". This does not imply coldness, or lack of enthusiasm, nor does it imply fatalism (Isherwood 363). The fatalist does not care, and may just not act. However, to act with detachment means to accept life "much more completely than those whose pleasures are tinged with anxiety and whose defeats are embittered by regret" (Isherwood 363). No matter how great or trivial the task, action should be undertaken wholeheartedly and devotedly. It is this performance of action which leads to true wisdom, which is behind all action is behind all life - the true Reality.

In terms of warfare, this is a marked change from the Christian idea of a just cause, which means that a "just interest" forms part of Western just war theory. A Hindu theory of war would be one without interest - one in which interest itself is destroyed. In many places, the Gītā describes the ideal karma yogi as one who delights in the welfare of all beings or one who acts with the attitude of rejoicing in the welfare of all beings (BG 5.25; 7.4). A karma yogi is supposed to be free from all enmity. According to William Jackson, this kind of call to action, unlike the Christian just war theory, does not lend itself to antinomian violence - the violence caused by the belief that under the gospel dispensation of grace, moral law is of no use because faith alone is necessary for salvation (175). This kind of Crusader mentality is definitely eliminated in Hinduism. Only after negotiations proved fruitless did Arjuna fight, because of duty not for the 
expansion of territory, or to others, or for revenge or plunder, but with detachment in regard to personal loss or gain. This is why, notwithstanding the examples given in Chapter 3 on militant Hinduism (mostly after the nineteenth century), for the most part extremists have not used the Gîtā to justify committing acts of violence (Jackson 175), certainly not to the extent that the Bible has been used to justify warfare.

The wise man, or true yogi is one who has given up all his desires (Klostermaier 105). He is "untroubled in the midst of sorrows and free from lust amidst pleasures, free from passion, fear and anger, without attachment of any kind, neither rejoicing in the good nor dejected by evil, drawing away the senses from the objects of sense as a tortoise draws in his limbs under the shell, acting free from self-interest - this is the 'divine state' that brings supreme happiness" (Klostermaier 105). This insight of yoga is the highest way of life. The way of salvation for contemplatives is through knowledge (jñana), but the way of salvation for actives is the way of works (karma). All work, except sacrificial actions (which can only be performed by the Brahmins) causes bondage. As a kșatriya, therefore, Arjuna is to perform his work as a yajña (ritual sacrifice) - free from all attachment, by renouncing the fruits of one's acts (phalatrṣnavairāgya) to further the interests of loka-samgraha (the good of the whole world). It is worth noting that the highest praise is not for the person who detaches himself from the pain and illusions of this world, but for the person who regards another's pain and joy as his own. As Kṛ̣na says: "He is a perfect yogi who, by comparison to his own self, sees the true equality of all beings, both in their happiness and distress, O Arjuna" (BG 6.33). Eliade regards this as the leitmotiv of Indian mysticism (161). 


\section{Kṛṣna Exemplifying the Act of a Perfect Sacrifice vis-à-vis Soldiering}

Kṛ̣nạa exemplifies himself as performing a sacrifice by his own continual incarnations on earth which are not to fulfil his own desires, which are all fulfilled, but to be an example to humankind (Klostermaier 105). Kṛ̣na reveals himself as a model for Arjuna to imitate. His perpetual activity of creating the world by the power of his prakrti does not fetter him, as he is only a spectator in his own creation. Likewise, man must imitate God who creates and sustains the world without participating in it (see Eliade 156-8). However, Kṛ̣na is not an ordinary mortal. Another concept developed in the Bhagavad Gìtā is the doctrine of avatāra, "coming down" or incarnation. Kṛṣna appears to be a normal human being, subject to the condition of samsāra, but, he is also portrayed as the unborn Lord of all being who has taken on human form through his supernatural power $(m \bar{a} y \bar{a})(\mathrm{BG} 4.5,4.6)$. As Kṛṣna states of his incarnations: Whenever there is a decline of righteousness [dharma] and rise of unrighteousness [adharma], O Bhārata (Arjuna), then I send forth (create incarnate) myself. For the protection of the good, for the destruction of the wicked and for the establishment of righteousness, I come into being from age to age" (BG 4.7-8).

Arjuna is greatly awed by Kṛ̣na's fuller revelation of his divinity and eventually asks Kṛṣna if he could see his divine body. Kṛṣna then endows Arjuna with divine eyes so that he may see his divinity - his cosmic form (viśva-rupa). When Arjuna beholds Kṛ̣na, he is terrified because he sees in Kṛ̣ṇa all the devas, divine beings, rṣis, nāgas and the infinitude of his form. He also sees all the warriors whom he knows rushing into Kṛṣna's flaming mouth and being destroyed. Kṛṣna tells Arjuna to fight but advises him to fix his mind on him, and to be devoted and offer sacrifice to him. Thus, in the 
Bhagavad Gìtā, Kṛ̣na establishes himself as the only goal, the only object of devotion. It is Krṣna himself who justifies yogic meditation and concentration and through his grace (a concept which begins to be formulated in the Bhagavad Gìtā), that the state of nirvāna, that is, "a state of perfect mystical union between the soul and its God" is obtained (Eliade 159). From this emerges the bhakti tradition wherein Kṛṣna promises Arjuna that a reliance and devotion to him, and even abandoning reliance on traditional dharma, will release Arjuna from his sins. Thus, in the Gītā, the three paths to liberation (trimārga) are enunciated: jūānamārga, karmamārga and bhaktimārga.

\section{An Allegorical Interpretation of the Bhagavad Gìtā}

It appears from a reading of the Bhagavad Gìtā, war itself in general terms, as an institution of military statecraft, is neither sanctioned nor condemned since it regards no action as having absolute value, that is, neither good nor evil. Kṛ̣na tells Arjuna to fight, yet this fighting has to be motiveless - a seemingly impossible task. Finally, the sermon is really about understanding the Self. In addition, attempts at historicising the battle of Kurukșetra seem futile given some of the details of the text. For example, the request of Arjuna as the general of his army to place himself between the two armies prior to the battle so he could survey the two sides would make little military sense (Yogānanda 10) and seems to emphasise the allegorical nature of the text. Isherwood observes that there is a duality in the story because of the dual nature of Kṛṣna as mortal and divine. In telling Arjuna to fight, he is employing relative values relating to soldiering, and these might be interpreted as condoning warfare. However, as a god, Kṛṣna is expressing absolute truth, the highest ideal that is meant to apply to life in general, and these two 
values are not contradictory but can be seen "to compose into a complete and satisfying philosophical picture. For life itself is double-faced; and any attempt at simplification will only bring us to ultimate confusion" (Isherwood 361). If the principal theme of the Gìtā is the nature of action rather than how to fight an actual battle, then an allegorical understanding is necessary.

The whole battle is an allegory with Arjuna representing the individual man (or devotee) and Kṛșna representing God (the divine Self within each human being) (Isherwood 359, Yogānanda 9). For Gandhi, the battleground of Kurukșetra did not refer to a physical battle on earth, but instead to the battle taking place in the human soul between good and evil impulses (Basham 87). According to Swami Dharmānanda, Dhṛtarāștra the blind king represents the blind sense mind or manas. This represents a person who draws only on the senses for experiences and pleasures. The hundred Kaurava sons of the king represent material desires and activities which are controlled by the physical self and whose pursuit leads to pain, suffering, disillusionment and sicknesses. Pāndu the younger brother of the king represents buddhi the faculty of discriminative judgement or the higher mind. This represents a person who is guided by the soul; the wisdom of the soul brings peace, contentment, health and harmony to the personality. The five children of Pāṇdu represent the faculties of the higher mind that aid in spiritual growth. These represent the small group of people in society who do not have their lives dominated in fulfilling and satisfying all their desires and needs, but who live dominated by the desires of their soul, which desires nothing in the material plane (Dharmānanda). The two armies, therefore, represent the forces of good (or enlightenment) and evil (or delusion), "the opposition within every unenlightened human 
being between his upward- and his downward-inclining tendencies" (Yogānanda 10) and not an earthly battlefield. Arjuna, representing the devotee, represents the majority of humanity in his desire to seek the truth. In this group, the desires and needs of the lower self are quite strong but they are also developing the knowledge of their higher selves. ${ }^{89}$ This creates a split in personality. The individual finds that he has two opposing types of desires and tendencies and he is not sure which one to follow. And as Arjuna approached Kṛ̣ṇa, so must we approach God for guidance.

As in a Socratic dialogue, the names of many of the main characters are also significant. The name Pāṇụ is derived from paṇ meaning white, and this signifies purity (Yogānanda 21). Kunti represents the power of dispassion and her children are Yudhisthira (divine calmness), Bhima (control of the life force or prana), and Arjuna (self-control). Madri, the mother of the two youngest Pạṇava twins represents the power of attachment to dispassion. The five Pāṇdavas together represent the five cakras, or spinal centres. Their wife Draupadi represents the Kundalini power. The fact that both sides are cousins represents the fact that both the positive and negative diametrically opposed interests are offspring of the same human consciousness. The blind king Dhṛtarāșțra and father of the Kauravas has Ambika (negative doubt) for his mother, since his blindness represents spiritual blindness. However, Pāṇḍu, has Ambalika, co-wife with Ambika, as his mother, and this represents the positive, discriminating faculty, thus Pāṇdu represents the application of that positive faculty. Dhṛtarāșțra's first wife Gandari (who begets the one hundred Kauravas) symbolises the power of desire, while his second

\footnotetext{
${ }^{89}$ These people are described in a way similar to Augustine describing the heart or will being divided into following both the law of the Spirit and the law of the flesh (Confessions 8.9.21-8.10.24).
} 
wife Sauvali, a woman from Vaishya Varna, who begets Yuyutsu ${ }^{90}$ represents the attachments that are formed in consequence of desire. Duryodhana represents egoinspired desires (Yogānanda 21-29). Finally, out of the one hundred Kauravas (and the one sister Dusshala), fourteen have names beginning with "Du", which signifies evil.

How does one approach war from a perspective that takes into account this allegorical explanation of the Gîtā? I will look at the views expressed by a few prominent thinkers.

\section{Gandhi and Ahims $\bar{a}$}

Many of Gandhi's ideas can be characterised as forming part of the modern Hindu philosophic view on God. Gandhi described himself as a sanātan̄̄ Hindu - one who follows the sanātana dharma embodied in the King of Dharma, Yudhișthira. He questioned what and where this dharma was: was it to be found in the teachings of the Brahmins or in one's own heart? He questioned and vehemently renounced what he saw as one of the greatest abuses of dharma and the Laws of Manu - untouchability. He was greatly influenced by the reform movement that preceded him and said of the scriptures:

My belief in the Hindu Scriptures does not require me to accept every word and every verse as divinely inspired. Nor do I claim to have any first-hand knowledge of these wonderful books. But I do claim to know and feel the truths of the essential teaching of the Scriptures. I decline to be bound by any interpretation, however learned it may be, if it is repugnant to reason and moral sense. (qtd. in Zaehner 171)

\footnotetext{
${ }^{90}$ Other names for Yuyutsu include Dhartarstra, Dhrtarastraja, Dhrtarastraputra, Karana, Kauravya, and Vaisyaputra. He is the only Kaurava who survived the war because he switched sides before the fighting began. He assisted the Pāṇavas by providing critical information about Kauravas' preparation and planning. He also saved the life of Bhīma by informing the Pāṇdavas about Duryodhana's cunning schemes, which included poisoning water.
} 
It is worth noting that although he regarded himself as an orthodox Hindu, Gandhi was no expert on the Hindu scriptures; he knew the Rāmāyana as translated by Tulsī Dās, and he first read the Bhagavad Gītā in its English translation by Sir Edwin Arnold when he was a young law student in London where he had contact with the Theosophical Society (Klostermaier 449). ${ }^{91}$ He did not have deep knowledge of the law-books on which the caste system relied (Zaehner 173). He read the Qu'ran, and also had much contact with Christianity. His roommate and friend in the late 1880s, Dr. Josiah Oldfield, a fellow vegetarian, took him to church on Sunday, and he was also supplied by Christian literature by his acquaintance Dr. Baker. However, his interpretation of Hindu scriptures was influenced mainly by his reading of Tolstoy's The Kingdom of God is Within You. He was also influenced by Ruskin's Unto This Last from which he drew three conclusions: first, that the well-being of the individual was contained in the well-being of all; second, that the work of a lawyer had the same worth as that of a barber, and that everyone has the right to earn their living through their work; and, third, that the life of manual labour (the life of peasants and artisans) was the most desirable life (Klostermaier 449-50). It was in his South African years, particularly when imprisoned that Gandhi was able to dedicate his time to the Gītā and works from other traditions (B.S. Clough 60). While he did read commentaries on the text, he found the Gitan itself quite accessible and penned his own commentaries on the Gītā in Gujarati in the light of his own experience, which he saw as being the practice of commentators before him (B.S. Clough

\footnotetext{
${ }^{91}$ As I described earlier, the Vedas and the Upanișads were considered secret knowledge and only for a select group of people and were not even translated into Indian vernacular languages until they had first been translated by Western scholars into European languages. It is for this reason that it is the more popular epics, especially the Gita, that are more influential in Hindu thought than other scriptural texts.
} 
63, 70, Doniger 626-27). He read Kṛ̣nạ's commands to Arjuna to kill his enemies as metaphoric saying:

[the Gìtā] is not an historical work, it is a great religious book, summing up the teachings of all religious. The poet has seized the occasion of the war between the Pāṇavas and the Kauravas... for drawing attention to the war going on in our bodies between the forces of good and the forces of evil. (qtd. in B.S. Clough 61)

To Gandhi, God is conscience (Zaehner 171). God is what his heart feels it to be. Gandhi was a vaiśya (from the merchant Baniya caste), and hence under no obligation to fight or soldier, but the circumstances of British rule compelled him to declare war, albeit a non-violent war of civil disobedience (satyägraha), against the ksatriyas of the time, the British government. Satyāgraha was more than passive resistance: it was action in the awareness of having truth on one's side and the firm belief that, ultimately, truth (satya) would triumph. It was "a religious movement, a process of progressive purification and penance" (Klostermaier 451). The satyāgrahis were truth defenders not law breakers (Klostermaier 460). However, despite his non-violent efforts, a bloody and violent war did erupt, and Gandhi could not rid himself of the guilt and responsibility for this violence (Zaehner 172). He often used fasting both as a weapon to reform or coerce others, but also to deal with his own errors and shortcomings (Doniger 625). Through his conscientious reading of the Gìtâ, Gandhi tried to rid the caste system of untouchability, (perhaps patronisingly) renaming the untouchables (asprha) "Harijans" or people of God, in order to bring them out of the shadows of untouchability (Zaehner 174). He did not attempt to abolish the caste system, but for him, the division in society was not to be a personal, but an occupational division, and he saw this kind of division as being 
beneficial to society. However, he rejected untouchability as being against ahimsa (Klostermaier 457).

Gandhi viewied Hinduism as a religion of peace because of his strong belief in the principle of ahims $\bar{a}$ which he translated as 'non-violence', the refusal to hurt any living thing, perhaps derived from his encounter with Jainism (see Basham 59, 63). Ahims $\bar{a}$ was a complement to truth. It is not just non-killing but it is an act of active love that extends to all living creatures from the smallest to the largest. It is God's activity in a human (Klostermaier 454). He recognised that life cannot be lived without the taking of life (Zaehner 176). He once remarked "Indeed the very word, nonviolence, a negative word, means that it is an effort to abandon the violence that is inevitable in life" (qtd. in Doniger 625). But recognising that violence needs to exist, for Gandhi, does not equate automatically to the fact that war must exist; he truly believed that a world without war was possible.

He drew upon the tradition of the Gìtā to make something of his own - the use of nonviolence as a political strategy against the British. Regarding the Gittā, Gandhi (perhaps erroneously) remarked:

It may be freely admitted that the Gîtā was not written to establish ahimssā... But if the Gîtā believed in ahims $\bar{a}$ or it was included in desirelessness, why did the author adopt a warlike illustration? When the Gītā was written, although people believed in ahims $\bar{a}$, wars were not only taboo, but no one observed the contradiction between them and ahims $\bar{a}$. (qtd. in Doniger 626)

Maybe he did recognise that his interpretations may be slanted more towards a nonviolent interpretation than the interpretation of others: "I have admitted in my introduction to the Gītā known as Anasakti [selfless action] Yoga that it is not a treatise on non-violence nor was it written to condemn war. Hinduism... has certainly not 
condemned war as I do" (qtd. in B.S. Clough 71). But, he also justified his interpretation by saying that the Gītā did not have to be a treatise on non-violence because the principle of ahims $\bar{a}$ has already been established before the Gītā (B.S. Clough 72). Furthermore, his is not the only non-violent interpretation, and this non-violent interpretation continues to have an impact on how the Gītã is interpreted by Hindus today.

Gandhi never advocated war; for him the struggle for independence was a dharmayuddha and in a dharmayuddha, no physical force could be applied (Roy, Ethics of Warfare 230). In 1938, he wrote "Not to believe in the possibility of permanent peace is to disbelieve in godliness of human nature" (qtd. in Appadorai 217). He claimed that world peace was being prevented by a lack of sincerity to wholly commit to peace. Peace was thwarted by imperialism, competition, greed, wants, glory and monetary gain. He viewed the race for armaments that he saw occurring in his time as a sign for impending catastrophe saying, "There is no escape from the impending doom save through a bold and unconditional acceptance of the non-violent method $^{92}$ with all its glorious implications" (qtd. in Appadorai 217). At the same time, he wrote that it is sometimes wise to see nonviolence in activities which appear to be externally violent: "I have come to see that... there is sometimes nonviolence in violence. I had not fully realized the duty of restraining a drunkard from doing evil, or killing a dog in agony or one infected with rabies. In all such instances, violence is in fact nonviolence" (qtd. in Trivedi 10). Therefore, perhaps a better translation of ahims $\bar{a}$ is non-aggression rather than non-

\footnotetext{
${ }^{92}$ Gandhi advocated only non-violent methods including civil disobedience and satyāgraha. One of his articles recommends the use of arbitration rather than the sword to resolve the conflict between Hindu and Muslim communities and, more generally, between India and Pakistan (see Appadorai 215).
} 
violence. ${ }^{93}$ However, despite his comment, it is doubtful whether Gandhi would have endorsed a war of humanitarian intervention. ${ }^{94}$

\section{Ahims $\bar{a}$ and Vegetarianism}

If killing animals for meat is supposed to subconsciously influence attitudes towards killing humans in warfare, as Drewermann believes, another important component of ahims $\bar{a}$ is the vegetarianism that is extolled in the Mahābhārata. In the Anuśasanaparvan (the thirteenth book), the vegetarian is described as the friend of all living beings, and vegetarianism makes warriors more desirable to beautiful women as well as sparing one from rebirth as an animal. Eating of flesh is supposed to make one fall into ruin. Yudhișthira proclaims nonviolence as the highest dharma, highest austerity and highest truth, and Bhīsma states that the eating of meat is against dharma (Chapple 149-54). Many Hindus are vegetarian, and Gandhi vowed to his mother (who was highly influenced by Jainism) before he left for England that he would never eat meat perhaps recalling these words in the Mahābhārata:

\footnotetext{
${ }^{93}$ Rosen compares Arjuna's battle as an extreme situation in which violence was necessary, and he then gives some modern examples which he characterises as similar extreme situations where mere non-cooperation would have been futile: ending the Holocaust or the Nazi regime, rectifying the situation in Tibet, stopping Saddam Hussein or Osama bin Laden (Rosen 26).

${ }^{94}$ See for example the letter written by Gandhi to Hitler on December 24, 1940 in which he explains to Hitler that the Indians have also been trying to rid themselves of British Imperialism. He addresses Hitler as his friend because he sees his own goal as befriending all people. Then he says that the Indians would not sink to the level of the British by using violence instead they sought "to convert them, not to defeat them on the battle-field" through an unarmed revolt. The tone of the letter implies that if she could, India would not even use violence against a regime like Hitler's to bring peace because "we have found in nonviolence a force which, if organized, can without doubt match itself against a combination of all the most violent forces in the world" (Gandhi, Selected Letters).
} 
If there were no meateaters, there would be not killers.

A meat eating man is a killer indeed, causing death for the purpose of food.

If meat were considered not to be food, there would be no violence.

Violence is done to animals for the sake of the meat eater only.

Because the life of violent ones is shortened as well (due to their deeds), the one who wishes long life for himself should refuse meat, $\mathrm{O}$ splendid one. (MB 7.115.29-31)

The practice of vegetarianism as described by Bhīṣma was a longstanding component of Vedic religion, and even short periods of vegetarianism are said to produce great merit. Christopher Chapple does explain that the non-violence advocated in the Mahābhārata speaks of ritual purity rather than some kind of state of pacifism or social activism. However, Gandhi, Tolstoy and Dr. King also interpreted these non-violent attitudes as part of a process of social uplift. Chapple, while stating that he is unaware of the actual statistics still opines that "it might be the case that a land of observant vegetarians would be quite peaceful, as such persons would not be likely to promote violent behaviour" (160). This, again, seems to support Drewermann's contention that the meat eating that some see Christianity (and other worldviews) as promoting (through ideas of man having dominion over all the creatures of the earth) increases belligerent attitudes.

\section{Swami Vivekānanda and War}

Swami Vivekānanda (whose religious education comes from an Advaita tradition) explains the idea of motiveless action as described in the Gītā. All actions bear within them an impulse of the tendency towards achieving mokșa. If the action is improper, it is called evil; if it is proper, it is called good. The basis of all ethical systems is absolute unselfishness because it leads to infinite expansion. For a Hindu, when a man reaches absolute unselfishness, he acquires infinite expansion. This infinite expansion is 
ultimately the realisation that man's individual personality is insignificant since he is the part of an infinite larger personality that includes all creatures - it is becoming one with the universe. Karma-Yoga is the unselfish action that enables reaching the goal of ultimate expansion. However, belief in religion, in dogma, in doctrine, in the supernatural, or God is not a pre-requisite for moksa - only working unselfishly is.

Swami Vivekananda then asks the question: Can we do good to the world? He answers, in an absolute sense, no; in a relative sense, yes.

No permanent or everlasting good can be done to the world; if it could be done, the world would not be this world. We may satisfy the hunger of a man for five minutes, but he will be hungry again. Every pleasure with which we supply a man may be seen to be momentary. No one can permanently cure this ever-recurring fever of pleasure and pain.

Therefore, in this world, the idea of permanent happiness seems impossible, but unlike in Augustine's estimation, this does not mean that there must be warfare. There is unhappiness in the world in many ways: poverty, illness, inequalities and natural disasters. So what kind of action must we engage in to live in this world if war is not a kind of remedy for evil? He says that there are two options. First, one can give up all concern with the workings of the world, to let it go and give up our desires, but he notes that this is almost impossible to do. The other option is that of Karma-Yoga - standing inside the world and learning the secret of work - that is, to work properly in the world. According to Karma-Yoga, work is the way one can reach the goal of liberation. The motivation for action has to be beyond common worldly motives or any expectation of return; the only motive must be the "inborn love of freedom". One must do good, because the idea of doing good is part of one's very being. Even doing good in order to 
seek eternal reward (such as heaven) cannot form part of disinterested and uninterested action.

Action in accordance with Karma-Yoga as described by Vivekānanda would suggest that war is not an action through which one can know the divine, therefore, war is not justifiable. He says that we cannot increase the amount of good in the world, but we can decrease the evil of warfare. The ultimate message behind Kṛ̣na's sermon to Arjuna is that liberation can only be in finding the truth about one's soul. The way to do this is to stop prioritising the physical and to stop our egotism. Acting with complete disregard of the ego will ultimately end wars because as Aldous Huxley remarked, wars, nationalism, tyranny, and revolution, inter alia, are a despair that are the result of egotism (35).

\section{Swami Parhamhansa Yogānanda and Humanitarian Intervention}

Swami Yogānanda states that the idea of upholding righteousness and doing good to others does seem to be a recurring theme in the Gītā. This has already been discussed when describing the kșatriya dharma and the role of the king to protect his people. Although Gandhi recognised that life cannot be lived without the taking of life, however, the "taking of life" he applied more to non-human entities, believing that towards humans, violence could never be the solution for conflict. However, Yogānanda goes a step further than Gandhi, explaining how at times, it may be necessary to take a human life. The Swami explains that the Gītā's proscription against doing harm refers to one's attitude. One should not wish harm to anything, but one may be obliged to kill harmful creatures. As the Swami says: 
Indeed, to protect them [harmful insects, bacteria, etc.], at the expense of human life would be a sin, for a man's body is more highly evolved spiritually than that of any lower animal.

If a lunatic were to enter your neighbourhood and start shooting at people, assuming there was no other way of restraining him, it might be karmically right, as well as necessary, to kill him. Better one deserved death than many that are undeserved.

There are times, as I said, when war is right, because necessary. Krishna, representing the voice of God, had declared at Kurukshetra that the side of the Pandavas was right and just. For Arjuna to refuse his duty as a warrior in that war would have been, not a virtue, but a sin. (54)

Yogānanda points out that every great scripture is multi-levelled, and he concludes that despite addressing spiritual needs, one can apply the Gìtā not only spiritually, mentally and emotionally but materially as well. He states, “Thus, Krishna's teaching is also true in a literal sense, for it urges the need for courage in righteous warfare. For righteous causes do of course exist" (11). This interpretation, therefore, allows for the possibility of humanitarian intervention as a means of upholding justice, however, it seems to rely on a literal approach in understanding of the war in the Gîtā. However, as has been discussed, the complexities and the nature of the Gìtā make purely literal approaches only provisional understandings.

\section{Swami Prabhavānanda: A Vedantic Understanding of the Sermon on the Mount}

Swami Prabhavanānanda ${ }^{95}$ explains his interpretations of the Gītā by trying to make some comparisons between Kṛṣna and Jesus. This kind of interpretation seems to further confirm allegoric, non-violent interpretations of the Gītā. Regarding "Blessed are the meek, for they shall inherit the earth", the Swami says that meekness involves

\footnotetext{
95 Swami Prabhavanānanda was born in India, and after his studies at Calcutta University in 1914 and his initiation by Swami Brahmananda, in 1923, he went to the United States and worked as an assistant minister of the Vedanta Society of San Francisco. After two years, he established the Vedanta Society of Portland, and in 1930 he founded the Vedanta Society of Southern California in Los Angeles, which became the largest Vedanta Society in the West.
} 
conquering our sense of ego, which is a constant theme in Hindu thought and a requisite for eventual liberation. Again, like Vivekānanda, he believes that conquering the ego will lead to ending war and peace on earth as he interprets "they shall inherit the earth" to indicate that meekness is not only for spiritual reward. Regarding "Blessed are the peacemakers, for they shall be called the children of God," which is perhaps the most prima facie example of pacifism attributed to Jesus, the Swami says that it is in knowing God that one can become a child of God and a peacemaker. He cites a related quote from the Bhagavatam which says: "He in whose heart God has become manifested brings peace, and cheer, and delight everywhere he goes" (qtd. in Isherwood 322). There is a realisation by the Swami that humans are not perfect souls, and that there may be occasions when violence and fighting occurs between people. However, he says that we have the potential to transform ourselves. Through the love of God, the Swami teaches that ultimately, fighting will be forgotten because everyone is engaged in the love of God (Isherwood 323).

"Blessed are they which are persecuted for righteousness' sake, for theirs is the kingdom of Heaven" appears to be the most prima facie aphorism of Jesus which would condemn violence in the name of religion or ideology. The Swami notes that many people may mock the religious aspirant, but that the aspirant should not choose to please the people of the world (Isherwood 323). Our actions, if they are to be truly spiritual cannot be about making a good impression upon others or about creating prestige. Sometimes, these actions may have to be contrary to what the whole world thinks, but they have to be done for the sake of truth, and this might involve acting alone, but 
ultimately, the only person a spiritual person has to please is God (Isherwood 324). ${ }^{96}$ This interpretation would, therefore, condemn any kind of war based on religious differences. The Swami cites Jesus in Matthew and he sees this as a clear injunction against war:

Ye have heard that it hath been said, 'An eye for any eye, and a tooth for a tooth.' But I say unto you, 'Resist not evil: but whosoever shall smite thee on thy right cheek, turn to him the other also...' Ye have heard that it hath been said, 'Thou shalt love thy neighbour, and hate thine enemy.' But I say unto you, 'Love your enemies, bless them that curse you, despitefully use you, and persecute you'. (Matthew 5:38-42)

The Swami says that loving one's enemies and not resisting evil is the highest truth which has been taught by all religions. Like Gandhi's interpretation, he believes that in the face of unrighteousness, one should not merely allow the unrighteousness to continue, but that the unrighteousness should only be addressed by non-violent means. Prabhavanānanda notes that in the Gītā, Kṛ̣na is also telling Arjuna to resist not evil, but not by indifference but by action: "He who is aware of both the grief and the happiness within every being to the same degree as he feels them within himself - him, O Arjuna, I hold to be the highest yogi" (see BG 2.55-71). This is an instruction that we must act in the world, but we must act in a particular way. We cannot be indifferent to human sufferings, but we must be sensitive to them, so that we can be aware of this suffering and consequently care for others because "[w]e begin to know that our own Self is the same Self in everyone else" (Isherwood 346).

\footnotetext{
${ }^{96}$ While an interpretation of this Beatitude may also be used as a justification by the religious aspirant to perform acts of violence in the name of religion, it is clear that Hinduism (not withstanding a small minority of nationalist radicals) would abhor the idea of a zealot using violence to promote a religious agenda.
} 


\section{Militant Hinduism: A Violent Interpretation of the Bhagavad Gītā}

As previously mentioned, there have been militaristic interpretations of the Gittā, and these have given rise to militant Hindu nationalist movements in India. When Tilak wrote his commentary on the Gìtā (Gìtārahasya), he went against many of the existing understandings that had privileged knowledge (jñanna) or devotion (bhakti) as paths to self-realisation and freedom, elevating instead the role of karmayoga (duty/action), even after knowledge of the Divine through jũanna and bhakti has been achieved (Kuruvachira 4). "The paths of renunciation and devotion advocate indifference to the world which in effect emasculates the devotees of the Gita and fill them with apathy. Thus, he was convinced that the original Gita did not preach the philosophy of renunciation but Energism (Karma Yoga). Hence he presents karma yoga as superior to renunciation and devotion" (Kuruvachira 4). He "took issue with every given doctrinal interpretation and philosophical argument, from monists to qualified monists, dualists, Vedantists and Mimansa philosophers on the Gita" (Kapila 446). Also rather than the universalist approach of Hinduism, as discussed earlier, Tilak took an elitist view arguing that Hinduism was superior over all other religions, and that all other religions are only partial truths, although he agreed that there should be no compulsion in religion (Kuruvachira 19).

Tilak viewed the interpretation of the Gìtā that ultimate freedom (in the form of detachment from the material aspects of the world) can only be achieved through desireless action as unrealistic; he described it as "treating the owner [self] of the house as a guest" (qtd. in Kapila 446). Bhakti and yoga are all worthwhile, but by focusing on the events of the battle as an historical event, again, breaking with traditions that view the 
battle as an allegory, Tilak saw in the Gìtā the right to a call to arms. As Kuruvachira states:

Tilak argues that, it is enshrined in the Gita that it is morally right to give measure for measure to immoral persons. Thus Tilak promotes a warriormorality and a warrior-religion. In the Gitarahasya we read "there [in the Gita] the warrior-religion has been pronounced [by Sri Krshna] to be superior to the law of fraternity". [...] He cites Krishna who declares that if everyone becomes harmless, warriorship cannot be continued and when once warriorship comes to an end, subjects will have no protectors and anybody will be in a position to destroy anybody else (5).

Therefore, killing or sacrifice, according to Tilak, if done for the protection of life was in keeping with the restoration of dharma (moral order) (Kapila 451). Since Arjuna was born a member of the warrior caste, it was his duty by birth to engage in violence. He argued: "If the Gita was preached to desponding Arjuna to make him ready for the fight - for the action - how can it be said that the ultimate lesson of the great book is Bhakti or Ghana [sic] alone?" (qtd. in Kuruvachira 7). This idea of sacrifice and duty were central to his thinking. He saw Western political theory hinging on the idea that happiness was the best way to sustain life in a collectivity, whereas Hindu thought favoured duty and desirelessness and thus sacrifice over self-interest. Tilak recognised that sacrifice was also central to Western political thought, however this sacrifice was conceptualised according to a calculus of interest, and is premised on the notion of historical time. Tilak instead chose to dissociate action from the fruits of action detached action (nishphal-karma) (Kapila 452). Tilak thought of the times we live in as being immoral (kaliyuga), and saw non-violence being suspended (Kapila 454). In the Gìtâ, Tilak saw that kinsmen were transformed into enemies, and he made the same correlations to non-Hindus. He did seem obsessed by the idea of racial purity, and his 
book Arctic Home of the Vedas written in 1903 added racial arguments to his political thoughts.

Tilak considered Gandhi's satyagraha as a weapon of the weak, and called for military force to defend Indian dignity (Kuruvachira 6). Ultimately though, Tilak's interpretation of the Gîtā was disastrous for Indian society. Communal violence against Muslims increased, and many revolutionaries who committed crimes of assassination, train derailments and other violence went to their deaths with the Gītā in their hands (Kuruvachira 7). Militant Hinduism and political extremism increased under the influence of Tilak's Gītārahasya and it "awakened Hindu consciousness among many Hindus, which resulted in increased anti-minority feelings and acts of violence and extremism in many parts of India" (Kuruvachira 8). It gave divine sanction to violence and Kuruvachira states that much of the communal violence in India today is justified religiously by using Tilak's interpretation of the Gîtā (Kuruvachira 24). Kuruvachira states that before Tilak, the interpretations of the Gìtā never really advocated violence ad he describes Tilak's interpretation as "subjective, distorted, far-fetched, deviant, perverse and dangerous" (22). ${ }^{97}$ The non-violent interpretations based on a different understanding of karmayoga of Hindu reformers like Vivekananda, Prabhavanānanda, Radhakrishnan or Gandhi appear overwhelmingly more prevalent. These commentators read the Gītā as a spiritual or moral allegory (Kuruvachira 35).

After examining the core doctrines of Hinduism, as well as interpretations of the Bhagavad Gītā, it is clear that the majority of interpretations lean towards non-violence

\footnotetext{
${ }^{97}$ Nicholas Gier says that religiously motivated violence was rare before the arrival of Muslim armies and European colonialists. He views militant Hindu fundamentalism as "the result of 'reverse' Orientalism by which some Hindu and Buddhist thinkers proposed theories of religious and cultural superiority by giving a racial interpretation to the Aryan hypothesis of European linguists".
} 
and a non-acceptance of war as a legitimate means of statecraft. I will now examine how a Girardan analysis of Hinduism tries to explain how the problems of mimetic desire are tackled without recourse to warfare.

\section{Violence, Sacrifice and Ritual Sacrifice: Applying Girardian Insight to Hindu Beliefs}

Julia Chinnick notes that the idea of sacrifice in the Vedas, as in the Bible, is ever present. Before $1200 \mathrm{BCE}$, this took the form of animal sacrifices. However, perhaps unlike the sacrifice of Abel or the goat on the Day of Atonement described in the Jewish Bible, or even the Eucharist in the Catholic Mass, in the Vedas, it was seen as a secondary part of the ritual. This is exemplified by a downplaying of the importance of the killing itself, for example, the words "to kill" or "to die" are not used, rather worded as "he makes consent", and the slaughterer is referred to as an "appeaser" (shamitr) . When killing and dying are referred to in Hinduism, it is done to nullify the acts of killing or dying with the idea that the animal does not die but goes to the gods. In addition, there is an avoidance of using words to describe that what is occurring is real (Chinnick 140). This is in great contrast to the idea of Jesus dying which emphasises the killing aspect of the sacrifice as a necessary part of salvation history. The acknowledgement of Christ's humanity makes his suffering all the more palpable. In Hinduism, sacrifice is secondary in nature, which accounts for the fact Hinduism developed from the early practice of killing animals (the ancient Hindus were meat-eaters), to the limited killing of animals in religious rituals, to a complete cessation of killing animals entirely (many Hindus today are traditionally vegetarian) and the substitute of vegetal sacrifices. According to Jesuit 
priest and scholar Francis X. Clooney, this leads "to a transformation of the performer into a "non-sacrificing person", and thus to a wider "discovery" of nonviolence. This transformation is also manifest, socially, in the shift to very largely nonviolent temple rituals (Clooney 112). ${ }^{98}$

The Upanișadic texts encourage an emphasis on ritual rather than sacrifice. Man the sacrificer becomes man the sacrifice as the act of renunciation, of alienating part of one's possessions or part of one's self replaces the sacrifice of animals. The puja ritual in the temple becomes a substitute for ritual violence. Clooney continues:

As the Upanișadic discourse gains prominence, the possibilities of serious conflict are discounted, and the real battles are narrowed to an internal field within the self. To generalize, we might say that in much of the Hindu tradition the real place for the struggle against violence, where nonviolence will triumph if it is to triumph at all, is within the individual person. External arenas in which combatants clash have already been judged as irrelevant or merely symptomatic of interior struggles. We must read the famous Bhagavad Gita in this light. Although the dialogue between Lord Krishna and the warrior Arjuna occurs literally on a battlefield as a bloody war is about to begin, and although the direct result of the Gita's teaching is the beginning of fighting, the tradition has generally seen the Gita as a teaching about the internal transformation of the warrior, in whom the discovery of self-identity is accompanied by the rooting out of anger, fear, greed, and hatred, and the cessation of the practice of dividing the world into enemies and friends [...] Vedanta can be understood to be linked to an understanding of the world in which conflict no longer makes sense because the very idea of opposition is increasingly reduced in influence and relevance. (116)

Even in the idea of vegetarianism, one can see a rejection of the killing-andeating society and an emphasis instead on the eternal self, "which neither kills nor is killed, and which, in its pure and uncompromised form, stands apart from all the ordinary

\footnotetext{
${ }^{98}$ Note that Chinnick is not entirely accurate when she says that there was a complete cessation of animal sacrifice in Hinduism. In some temples in Tamil Nadu, as well as in some eastern Indian states and in Nepal and Bali, animal sacrifices (e.g. goats, roosters) known as bali still occur today. This is especially seen in the sects which practise Shaktism (Śăktam ) focussing on the worship of the Hindu divine mother Sākti or Devī. However, at least from an Advaita standpoint, Chinnick is correct.
} 
negotiations of life" (Clooney 117-18). The austerity of vegetarianism and non-violence is seen as removing sin and is connected with an awareness that self/atman is present in all beings. In the Hindu temple offering, a vegetarian, usually sweet offering is made to the gods (naivedya), the deity receives the offering (bhogya) and then it is redistributed rather informally to participants (prasād) (regardless of faith) as a token of hospitality. There is an idea of giving to the gods, and receiving blessing to the gods. The Christian Eucharist shares the idea of offering to God (bread and wine), and receiving from God (his sacrament). But in the Christian communion (shared by only the faithful), the terms "body", "blood" and "flesh" exemplify the gory nature of what is viewed as an historic event in the salvation history of the world. What is received is the result of death, sacrifice and should be received only with strict reverence.

\section{Violence as an Instrument of the State}

A.L. Basham notes that when warfare did occur (prior to the Moghul conquests) it was "warfare of the inconclusive type traditional to Hinduism, which never pushed a victory home and thus inhibited both the building up of stable empires and the establishment of firm alliances" (56). Basham explains the reason the Indian princely states succumbed to foreign invasions with reference to the Hindu political system itself. He explains that the rulers of India were intensely conservative, especially in military matters. Therefore, when wars did occur internally in the subcontinent, states were generally equally matched. Hindu foreign policy did not advocate conquest and annexation of external kingdoms. Therefore, when large marauding hoards appeared 
from the North, the lack of strong alliances between stratified, small Indian kingdoms, ${ }^{99}$ combined with outdated military equipment and methods, quickly led to conquest by the Moghuls. After the Moghul invasion, further non-violent ideas came to the forefront. Clooney says that one reason for this is that when traditional kingship broke down in a Hindu kingdom, either following the Muslim and later, European invasions of the subcontinent, Hindus no longer held positions of power, and so there was no proper allocation of force to any Hindu groups. "The principles remained the same, but the exercise of force temporarily 'disappeared' in Hindu society, being alienated and assigned to non-Hindu rulers whose specific concern, however useful they might turn out to be in practice, could not be the defence of dharma in the expected Hindu sense" (Clooney 125). Therefore, the lack of power of Hindu groups after foreign invasions further developed ideas of non-violence culminating in the ideas of Mohandas Gandhi.

Gandhi's perspective on the use of violence, Clooney explains, represents the historic reality of the lack of a Hindu king (during the time of the Raj) as well as the fact that he was not a kṣatriya and he had strong Jain influences. But, this kind of nonviolence is almost Gandhi's own contribution to Hindu political thought, although he did base it on traditional Indian ideas of non-violence. Responding to violence with nonviolence as Gandhi did was a conscious non-mimetic response to violence. This helps to bring awareness to the mimetic nature of violence while simultaneously ending the circle of reciprocal violence (Shinnick 142).

\footnotetext{
99 To put things into perspective, the Indian subcontinent has a landmass approximately one-third the size of the United States, but at one time had over 600 princely states.
} 
It is only in the last fifty years with the emergence of the modern Indian state that Hindus are again manifesting differing attitudes towards violence and non-violence. Of course, perhaps the legitimacy of the modern state to use violence is countered by the fact that, as Subedi has pointed out, the modern Indian state does not in any way represent the ancient Hindu idea of a country-state. Immediately after independence, India seemed to immediately reject the absolute non-violence of Gandhi by engaging in wars with Pakistan and China, and by testing of nuclear weapons. In some ways, I think this represents a large step backwards when the trajectory of Indian thought seemed to be moving further and further away from violence.

\section{Hinduism and the victim: karma as an expression of violence}

It appears that from a Girardian standpoint, the violence of warfare (as occurring between states) is deflected or replaced by the impartial violence of the law of karma. Therefore, rather than seeking catharsis from mimetic tensions through violence towards the Other, the violence is directed inwardly towards individuals within the society. Through the ideas of reincarnation, the caste system and karma, Hinduism tries to silence the voice of the victim and to conceal the scapegoat mechanism which is marginalising certain groups of people from society. Karma is portrayed as the agent of the violence and agent of retribution for those who were evil in a previous life (Shinnick 143). The idea of karma might lead a Hindu to "avoid direct violence out of a conscious idealization of non-violence and also out of a perhaps conscious, perhaps not conscious, wish to advance my own soul on its journey to 'attain the world of Brahman' and 'not return again"' (Shinnick 144). Furthermore, Julia Shinnick explains that "the Hindu idea 
of karmic justice provides an unconscious retributive and substitutive (mimetic) violence against those who commit violence" (144). Therefore, if I am harmed by an assailant, I am less likely to respond mimetically by violence, but am comforted by the idea that the assailant will receive their just desserts. Finally, when one sees impoverished or other unlucky strangers, the Hindu might assume that this person deserves his current status for harm they might have committed in a past life. Therefore, karma acts as an impersonal mimetic substitution for violence, therefore having no need for a scapegoat mechanism (Shinnick 144) which might help to reduce warfare. It may even serve to reduce the likelihood of humanitarian intervention because people suffering under an oppressive government might be viewed as deserving of this suffering because of their karma.

One of the important comparisons to be made is how the victim is viewed. In Christianity, we see the victimhood of Christ, the victimhood of an innocent. In Hinduism, very early on, animal victims are displaced from ritual sacrifices. Clooney states:

Hindu thinkers did not development [sic] a theology of the victim, and did not interpret violence and nonviolence in terms of victims. The victim was first moved off-stage, and then rendered symbolic through substitution with simpler, lower life forms. Finally - if one wants to identify a trajectory - the notions of victimizer and victimized are interiorized, as one's own self becomes both the agent and recipient of violence. Consequently, the Hindu emphasis seems to have been focussed less on victims and more on human person as agent - as confronted with the opportunity to be violent or nonviolent, having to decide how to react in the face of others' choices. It is ultimately the agent of violence who suffers most, after all. (137)

Hindus do not nurture a sense of the victim as do Christians, and by extension, the idea of sacrificial love even dying for others, is missing. The reasons for this lack of vocabulary of victims are "probably because $[\ldots]$ there is a different sense of human experience and 
agency in the face of the possibility of violence" (137). In terms of Bailie's examination of Christianity, increasing the empathy for victims actually increases victimisation and violence; perhaps the opposite is also true. Clooney ends his discussion questioning whether Christianity could find room for a reflection on violence and non-violence that is based not on the image and vocabulary of oppression, victims and suffering for others. Perhaps, this could be an important contribution of Hindu thought, which may alter the current stance on the use of violence in statecraft (137).

\section{Conclusion}

This chapter has examined how despite the presence of rules of warfare within Hindu political thought, unlike the Christian just war doctrine, which seemingly expanded justifications for warfare, Hindu thinking seems to continually attempt at reducing justifications for war, culminating in the ideas of Gandhi which called for total non-violence. This move towards non-violence seems to be the majoritarian viewpoint, and it is supported by many of the metaphysical assumptions of Hinduism and by an allegorical reading of the Gītā. The Gìtā is a guide to spiritual liberation, not a manual for warcraft, and therefore, good actions are what bring us closer to God and to realisation of our own divine nature.

As a result, I think the idea of a just war in Hinduism is not possible since war places a greater emphasis on the material consequences of this world, and although Hindu philosophy is interested in this world, it is more interested in spiritual consequences in which war plays no part. Even Yogānanda, whose interpretation of the Gītā might allow for a just war doctrine states that the first and central message of the Bhagavad Gītā 
concerns the "courageous inner struggle toward the victory of soul principles over spiritual sloth and material ease" and not "mortal, physical combat" (12). The over-all theme of this epic is to present a guideline for the return of the soul from a journey of disillusionment to God. As in Socratic dialogues, the significance of the names and miraculous birth accounts of the characters in the Gìtā seem to favour an allegorical interpretation above any literal interpretation. Interpretations of Christian texts in a decidedly and uncompromisingly pacifist manner by adherents of Vedānta further support an overall emphasis on peace rather than an allowance of war.

If one were to compare Hindu with Christian metaphysical assumptions and psychological dispositions that contribute to warfare, the following list can be constructed. Many of these points may help to explain how Hinduism could have developed a political theory which eschews war in favour of total non-aggression:

(a) There is no subservience of science to scripture in the interpretation of ancient texts and scripture;

(b) A long history of interpretation of scriptures as allegory, therefore, historical truth is neither sought nor viewed as important for believers; non-Hindu truths are also never vilified nor brushed aside as mythological;

(c) A belief in man being born in a veil of ignorance, but this can be overcome through certain practices chiefly renunciation (no practices are obligatory); ignorance of one's true nature is the cause of suffering not Original Sin;

(d) No undue emphasis on victimhood nor arousal of empathy for victims because of the doctrine of karma. Therefore, the scapegoating mechanism found in archaic religion is not destroyed and the society is allowed to experience catharsis, thus ending cycles of violence;

(e) Absence of a violence-of-God tradition found within Scriptures compared especially to the Old Testament - unlike in the Old Testament, God never induces wars between humans;

(f) There is no psychological fear of God as God is not anthropomorphised; rather Brahman is seen as the limitless state to which all souls eventually go; 
(g) While suppression occurred at times (e.g. Laws of Manu), Hinduism generally shows remarkable gender equality; sex is less vilified and is considered an important part of life (compared to, for example, the misogynistic statements found in the Pauline epistles) for representations of union with God (e.g. erotic temple sculpture, Kāmasūtra).

All of these points appear to be in stark contrast with many of the key Christian assumptions about reality as well as ideas of fear that are part of Christian psychology according to Drewermann. The differences between Christian and Hindu worldviews will be further discussed and contrasted in the next chapter. 


\section{Chapter 5 - Final Comparisons: Christian and Hindu Worldviews and Ideas of}

\section{Warfare}

We Hindus have now been placed, under God's providence, in a very critical and responsible position. The nations of the West are coming to us for spiritual help. A great moral obligation rests on the sons of India to fully equip themselves for the work of enlightening the world on the problems of human existence.

(Swāmi Vivekānanda qtd. in Klostermaier 438)

Originally, the just war theory arose as a concept to minimise the use of force by trying to limit the situations in which it is used, and trying to ensure that the result would be the greatest good with the least harm inflicted. However, what the last few decades especially has taught us is that in the aftermath of war, it is civilians who lose the most. Despite initiatives like R2P, some regimes still get away with murdering their civilian populations with little interference from other countries; in addition, when intervention does happen, there are always external factors at play that suggest that the motivations for intervention are never completely selfless.

As I have shown, both Christianity (Chapters 1 and 2) and Hinduism (Chapters 3 and 4) ground questions of ethics and warfare in metaphysical assumptions. We can now compare and contrast these roots and generate empirically testable questions. What the research does indicate is that many of the factors that seem to influence the acceptance of a just war theory in Christianity are not present in Hinduism. What it also indicates is that these factors, which historically gave rise to the modern just war doctrine as described in R2P, are unique to a particular historic kind of Christianity, and that many of 
these factors cannot be found either within several Christian denominations (Orthodox, Mennonite, Amish, Hutterite) nor are they at play in the worldviews of other belief systems (Hinduism, Buddhism and Jainism). Not that these factors are extinct in living Christian congregations - far from it; these beliefs are alive in the majority of Christian churches. Roman Catholic, ${ }^{100}$ Lutheran, ${ }^{101}$ Presbyterian, ${ }^{102}$ Anglican, ${ }^{103}$ Methodist,${ }^{104}$ Mormon $^{105}$ and Southern Baptist ${ }^{106}$ congregations, inter alia, are all inheritors of Augustinian metaphysical assumptions and the Catholic just war doctrine it gave birth to. Each of these faiths endorses the idea of a just war. When looking at militant Hinduism however, what can be shown is that some of the factors which influence just war in Christianity (such as historicity and literal interpretations of scripture) creep into the worldview of these radical Hindu activists who interpret the Gītā as a call to arms. Related to this, when one looks at pacifist Christian thinkers, they seem to deny some of the assumptions associated with Augustinian Christianity (such as historicity, or literal

\footnotetext{
${ }^{100}$ National Conference of Catholic Bishops, The Challenge of Peace (Washington, DC: United States Catholic Conference, 1983), para. 87.

${ }^{101}$ James M. Childs, Jr., "Nuclear Policy and the Ethics of Anticipation," in Peace and the Just War Tradition, ed. Michael J. Stelmachowicz (New York: Lutheran Council in the USA, 1986), 66. Also John F. Johnson, “Can War Be Just?” Lutheran Witness 122, no. 1 (January 2003), 6.

${ }^{102}$ For further information on how this church views the idea of war, see 181st General Assembly (1969), 694, in Presbyterian Church (U.S.A.), A Composite Review of General Assembly Statements on

Peacemaking and the Arms Race (New York: Office of the General Assembly [PCUSA], 1984), 6. Also Presbyterian Church in America, "Christian Responsibility in a Nuclear Age," www.pcahistory.org/pca/1439.html (accessed July 1, 2013) (citing Westminster Confession).

${ }^{103}$ For further information on how this church views the idea of war, see Episcopal Diocese of Washington, The Nuclear Dilemma (Cincinnati: Forward Movement Publications, 1987), 107. See also 74th General Convention, Cross Before Flag (Chicago: Episcopal Peace Fellowship, 2005), 39.

${ }^{104}$ For further information on how this church views the idea of war, see United Methodist Council of Bishops, In Defense of Creation (Nashville: Graded Press, 1986), 33.

${ }^{105}$ For further information on how this church views the idea of war, see Edwin Brown Firmage, "Violence and the Gospel: The Teachings of the Old Testament, the New Testament, and the Book of Mormon," BYU Studies 25 (1985): 48. I believe a valid argument can be made, however, that Mormonism is removed from Christianity in many ways because it appears to have considerably different beliefs on the nature of Christ than does mainstream Christianity. Nonetheless, perhaps it has held onto enough metaphysical assumptions of Augustinian Christianity to make possible a Mormon just war doctrine.

${ }^{106}$ For further information on how this church views the idea of war, see Richard D. Land, "The Crisis in the Persian Gulf and 'Just Wars,"' Light (April-June 1991): 2.
} 
understandings of scripture) which influence attitudes towards war, and for some aspects (e.g. tolerance for other faiths) their worldview appears closer to an Advaitan one than an Augustinian one.

I will first summarise what the distinct polar differences between Christianity and Hinduism are regarding each of the questions posed by Apostel that were described in the Introduction. After discussing how the assumption has the potential to affect thinking about warfare, I will propose some questions for further empirical testing which could be conducted to evaluate the influence of worldview to theories of war. Ultimately, this framework could be applied to other worldviews and this could allow for the generation of empirically testable questions on attitudes towards warfare. If a state's worldview could be constructed, it might allow for predictions on which wars states are likely to support or reject. Understanding personal worldviews of combatants may allow one to predict how and why these combatants choose to accept and internalise certain rules of engagement while rejecting other. It could also help clarify the rules for when certain acts are to be deemed as war crimes rather than legitimate combat strategies.

\section{What is? (Ontology - what is the model of reality)}

Christianity's view of the problem of the human condition is that of $\sin -\mathrm{a}$ condition of all humanity since the Fall of Adam and Eve in the garden. Sin consists of action that is contrary to the will of God, or in directing one's love away from the love of God. Resolution of the problem comes from orthodoxy (the acceptance of a certain creed which the Church has decided on) and a belief in the saving sacrifice of Jesus. The solution, therefore, is dependent on instruction from others and results in the formation of 
communities of believers, validating both group and individual efforts. In contrast, Advaita Vedānta sees the problem of the human condition as ignorance of our true nature that our soul and the essential part of all things are connected to the Infinite. The solution to the problem is knowledge, which can be gained through study or meditative practice, but it is an individual's own quest to renounce the attachments of this world, based not on following of a declared orthodoxy but by emphasising orthopraxy and following dharma (although a saimnyāsin is exempt even from ritual orthopraxy).

\section{Comparative analysis}

Christianity is premised on the existence of a two-tiered world - heaven and earth. There is a metaphysical idea of the world as a place of constant struggle between the forces of good and the forces of evil. Therefore, there is a view of the world as a place of conflict. People who commit acts which are disagreed with by others (be they political, medical, sexual, social, gastronomical - almost any action is capable of being disputed) are seen as being evil, and somehow the workings of the devil. Infant babies in the rite of baptism are first exorcised to cleanse them of evil which they are said to innately possess by mere virtue of being human and therefore, inheritors of Original Sin. Jewish ideas of a tempter or accuser are replaced by ideas of Satan as the embodiment of a malicious force in the universe, and he is seen as the reason for evil. ${ }^{107}$ Wars are often an expression of righting some wrong and fighting some evil, and a necessary part of living in an imperfect world.

\footnotetext{
${ }^{107}$ Cf. Jeffrey Burton Russell, Satan: The Early Christian Tradition, Ithaca, NY: Cornell University Press, 1981.
} 
Hinduism has various propositions concerning the nature of reality. One is that the universe which we perceive by our senses is only an appearance, and this includes evil, which itself maybe an illusion. Behind this appearance is Brahman - which is the unchanging reality. The idea of $m \bar{a} y \bar{a}$ has two results in terms of socio-psychological analysis. The first is a trend towards other-worldliness and a withdrawal from the world because what one can perceive with the senses and intellect is understood as only an external superficial experience of reality which masks a deeper, hidden "real" reality. The second is the opposite - a trend to engage in the world, by for example, fighting injustice (e.g. Gandhi against the British government). There is a sacramental perception and understanding of reality in which everything is an expression of the divine oneness. Nothing in this world is to be devalued but, everything should be experienced and engaged with in all possible ways. It is the tension between other-worldliness or asceticism and the perception of the whole of reality as divine that defines Hinduism (von Brück 13). In other words, dualism in Christianity relies on poles of Good and Evil, while in Hinduism, it relies on poles of Illusion and Eternal Being.

\section{Understanding the Human Condition}

In Christianity, the human problem is sin, which not only causes suffering in this life but also could lead to eternal suffering in the next life. The solution, then, is salvation from sin, temporal suffering, and eternal suffering. According to Christian 
belief, salvation is made possible by the life, death, and resurrection of Christ, which in the context of salvation is referred to as the "atonement". 108

Christianity views everything that God created as good, however our free will allowed us to have choices between good and evil. Human existence itself is characterised as a struggle between good and evil. Because Adam and Eve sinned, we are also prone to making bad choices. Original sin makes humans agents in the origin of evil owing to their deficient moral wills (Gier). But human nature can be restored by grace. In the Middle Ages this kind of "grace" was said to be given out by indulgences which were supposed to reduce their time in Purgatory. Many joined Crusades in order to save their souls as risking one's life for the holy lands was seen as a virtuous task.

In addition to its conflictual view of the world, the importance of the sacrifice of Jesus in which God Himself becomes the victim creates in Christians an emphasis on victimhood in Christianity. God is seen as the champion of the weak, the outcast and the victim, which forces Christians to (over) empathise with the victim. This encourages the idea of sacrificial love and it creates a positive view of giving one's life as a sacrifice for a just cause (in order to save victims, to save holy sites, etc.). Arousing empathy for victims destroys the scapegoating mechanism (as explained by René Girard) resulting in a failure of a society to experience catharsis in warfare, thus perpetuating a cycle of violence which causes an increase in victimisation and violence. Victimisation offers absolution and no accountability and creates entitlements to sympathy, support and reparations (e.g. Nazis said that Germans were victimised by Jews). Empathy for

\footnotetext{
${ }^{108}$ I have even heard some theologians purposely mispronounce this word as "at-one-ment" signifying that the unity with God that Adam and Eve enjoyed in Eden had to be restored - God and mankind had to be made one again - and this was only possible through the sacrifice of God sending his Son to die. In Jesus, God is seen as uniting himself in solidarity with the human condition in order that humanity can be saved from the human condition.
} 
victims $^{109}$ is the source of moral uneasiness and social restlessness in the West (Bailie 19). Historically, this encouraged Christian martyrdom including Crusades - fighting for a Christian cause where the victim is the faithful Christian soldier or the captive city of Jerusalem. Today, it encourages violence as punishment for sin, and some Christians practise(d) corporal mortification as a form of sacrifice, in solidarity with their crucified God. Christians are forced to look elsewhere in attempting a "sacred" justification. Thus, race, ethnicity, nationality and ideology are endowed with religious significance and these terms provide those in a secularised or Christianised world with a facsimile of the sacred.

Christianity also lacks the sacrificial mechanisms of archaic religions, and Biblical texts have been stripped of the sacredness from sacrifice as events come to be viewed historically rather than allegorically or mythologically. There is also a belief by many denominations that only faith in Christ as the sacrifice that saved sinners is a requisite for eternal salvation. This leads to intolerance for those who do not believe in Christ as the ultimate sacrifice that saves. Mimetic passion cannot be converted into social unanimity, psychological stability, and a renewed sense of moral rectitude, and so, mimetic desires linger on. With no scapegoat on whom these desires can be focussed and driven out, (because the only possible sacrifice which will make any difference, i.e. killing the Son of God, has already been made), violence continues. Drewermann says that a typical Christian attitude consists of subjectively wanting peace but objectively

\footnotetext{
${ }^{109}$ Note that there are some positive aspects of empathising with the victim because it encourages help for those in famines, in disasters, the poor and the marginalised in general. However, as already discussed in the Introduction, the kind of empathy which manifests itself as war (in the precepts of R2P) has been seen even by Christians today (even amongst those denominations that support the just war doctrine) as overstepping ethical boundaries.
} 
making war, and this is now what dominates the once Christianised world in secularised form.

In Hinduism, the human problem is that of human suffering and sorrow (duhkha). Encounters between teachers and students in the Upanișads illustrate that both secular knowledge (apara vidhy $\bar{a})$ and scriptural learning (i.e. a superficial mastery of texts and memorisation of the words) do not address or resolve the problem of sorrow. It is only with the deeper liberating knowledge that one receives when one approaches the texts with the help of a guru that one can attain true higher knowledge (para vidhyā) about eternal things and not perishable things of this life. It is not that secular knowledge is not important, but this knowledge does not liberate one from the fear of mortality or satisfy the human urge for completeness of being. Hinduism recognises that the pursuit of wealth (artha), pleasure ( $k \bar{a} m a)$ must be tempered by dharma (ethics and moral values), but ultimately, materialism is only a false contentment because of the transient nature of the pleasures of the world. It does not lead to lasting happiness but only fleeting moments of happiness. It is only in living the reflective life, with detachment (nirvedam) that one is fulfilled and one becomes awakened to the necessity of liberation (moks $a)$ - an attainment that is free from the constraints of the finite. What everyone truly desires is the uncreated (akrtah) - the absolute and limitless Brahman (Rambachan 9-17).

Hinduism teaches that human beings are living in a condition of self-ignorance not a complete ignorance, but a misunderstanding about the nature of the self. Knowledge of the infinite is said to be the only way that the human problem can be resolved, and according to the Upanișads, one must first know the infinite to know one's 
true self (see Rambachan 52). ${ }^{110}$ If one is not different from the limitless, then the problem is one of self-ignorance (avidya $)$. Because of this ignorance, one feels separated from one's true nature. The Advaita tradition stresses that the Self is not two. The body is an object of one's awareness. The one Self is the Self of us all. The identity of Self in everything implies that the self transcends space and time, but it is ignorance that prevents this realisation of knowledge of Self. Misconceptions about the nature of the Self is the primary cause of human sorrow (Rambachan 44-45). It is not in accepting a particular creed, but an individual's own journey to renunciation of the material that can alleviate the human condition. Through this kind of thinking, there is much less animosity towards the Other, and possibly a reduced possibility of demonising the Other if one believes that we are all interconnected in this way.

Hinduism, and perhaps most other religions (though not all, e.g. some Shia sects in Islam) do not create any emphasis on victimhood. Hinduism focuses more on the human person as agent. Victimiser and victimised are interiorised, as one's own self becomes both the agent and recipient of violence (cf. Clooney). This may influence a reduction in victimisation and violence in Hindu states. There was a gradual shift in thinking away from animal sacrifice to the idea of self-sacrifice to achieve liberation. This eliminated the need for sacrifice, but instead, there is the idea of offering to the gods. Hinduism solves some of the tension created by the mimetic passions through the doctrine of karma, where the violence perpetrated is that by the universe itself and by the

\footnotetext{
${ }^{110}$ The lesson that the Upanișads teach is that the self(I) (atman) is the infinite (Brahman). This is summarised in the four great Upanișadic sentences (mahāvākyas): "That Thou Art (tat tvam asi)" from the Chāndogya Upaniṣad (6.8.7) of the Sāma Veda; "This ātman is Brahman (ayam àtma brahma)" is taken from the Mānḍukya Upanișad (2) of the Atharva Veda; "Consciousness is brahman (prajñanam brahma)" is taken from Aitareya Upanișad (5.3) of the Rg Veda; and "I am brahman) (aham brahmāsmi)" is taken from Bṛhadāraṇyaka Upaniṣad (1.4.10) of the Yajur Veda (Rambachan 52).
} 
soul of the individual himself/herself as the violence of being born of lesser birth. This in itself creates more interconnectedness between all creatures, and many Hindus are vegetarians and refuse to kill any sentient being for food. Vegetarianism itself may promote less violent behaviour and the Mahābhārata extols the virtues of vegetarianism as a way of reducing violence. A belief in karma, therefore, may inhibit violence because a Hindu would view justice as eventually being meted out on rogue individuals through rebirth. Of course, this is not to ignore the fact that especially in rural India, even today, violence can be seen between those of upper castes and lower castes in the way that the lower castes are treated and perhaps the indifference to reform the system. But, this, according to Shinnick, is what leads to a reduction in war and serves as a vent for mimetic passions.

\section{Potential questions for empirical testing}

Some potential questions which could arise from studying the connection between warfare and ontology are: Are worldviews which prioritise orthodoxy over other aspects of religion more belligerent? Does a belief in the fallen nature of man create an excuse for warfare? Do high levels of empathy for victims cause one to support warfare more if it can be shown that innocent victims (civilians) will be saved? Does belief in the existence of Satan (djinns, demons, etc.) or any other malevolent force with independent agency in the world influence one's ideas of warfare and one's perception of the enemy? 


\section{Where does it all come from? (Explanation - a model of the past)}

Christianity believes in one God, who created everything from nothing. The Earth and human beings are also objects of creation, happening at a particular time in the history of the universe. God is often portrayed anthropomorphically, and this is further heightened through the doctrine of the incarnation. Hinduism, by contrast believes in a supreme universal spirit or sacred power (Brahman) but creation itself is an act that happens again and again, followed by destruction and recreation, and God is not necessarily causal to creation. Various personalities of God in the various deities do anthropomorphise God, but to a much lower degree than does Christianity, especially through the doctrine of the Incarnation.

\section{Comparative analysis}

\section{Creation myths}

Christianity proposes that God created everything in existence from nothing and that at the moment of creation, space, time and matter came into being. Therefore, there is a belief in a linear temporal order: God created the earth and all it contains in six days ${ }^{111}$ and that at some point, the world will end and Jesus Christ will come again to judge the living and the dead. Tied with this cosmology is a sense of historical consciousness that is bound to the historicity of religion. Because of its links with Judaism, it is tied to a belief in apocalypticism - a belief that the world will eventually end, and this end will be accompanied by a major confrontation between the forces of

\footnotetext{
111 This kind of worldview is not extinct even in our times. In Kentucky, there is a museum built at the cost of $\$ 27$ million dedicated to the belief in a literal interpretation of creation as described in Genesis. The museum presents the view that the earth is approximately 6,000 years old. A considerably more modest attempt at such a museum also exists in Big Valley, Alberta.
} 
good and evil in which evil will be conquered. ${ }^{112}$ In Christianity, historicity becomes the criterion of religious truth. By historicising its own mythology, Christianity is very hostile towards mythology, which is how it tends to characterise and also discredit and demonise other religions, thus increasing justifications for conflict with unbelievers or dissenters.

In the two accounts of creation in Genesis, the meta-narrative is that God created man from clay, and woman is seen as being created as a helpmate for man from the rib of man. This account, known as the "subordinating of women account" is most dominant in Christian thinking as it seems that these views were built up by Paul ${ }^{113}$ (Stagg and Stagg 16-20). Perhaps women are even blamed for misfortune since the Bible says that it was Eve who succumbed to temptation and she tempted Adam to sin. This has been the source of much inequality for women in a society which tends to be dominated by men. Some feminist IR theories argue that there would be less conflict in the world if women occupied more power roles (Weber). Drewermann notes how patriarchal attitudes favour characteristics associated with hunting, and war is merely the hunting of humans.

The Book of Genesis describes that when Adam and Eve sinned by disobeying God, the first couple were cast out of the garden as punishment. Known as the Fall, this is seen as the mode through which sin entered humanity. This account identifies sin as inheritable and located within linear time. Because of this, we are all fallen, sinful people who are constantly tempted by the material trappings of the world. And it is because of

\footnotetext{
${ }^{112}$ The influence, in Christianity at least, comes more from Manichean dualism and, to a lesser degree, from the Zurvanites.

${ }^{113}$ Modern Biblical scholarship has shown that many of the misogynistic statements attributed to Paul (e.g. 1 Corinthians 14:33-36) may not have been part of the original Pauline epistle but were scribal additions to the text (see Ehrman 183-84). Therefore, modern interpretations of the Bible that take into account recent scholarship would be far more accepting of women than older interpretations.
} 
this sin that the ultimate sacrifice - God had to come down in human form and die - had to be performed. The implication of the Fall is that human nature is seen as being originally pure, but the sinful act of the Fall causes a fall from consciousness of the divine. Original sin can be viewed as an inherited refusal to be conscious of God, something that can be seen in the accretion of sins as children grow from "innocent" to "jaded". However, this fall from consciousness is not permanent, because by conquering sin, this perfection can be reached again, but in the afterlife. The Fall is perhaps the starting point of the just war theory. Because of the Fall, thinkers like Augustine described the earth as being made up of good and evil people, where the good are those who have subjected themselves to the will of God. The evil are those who turn away from God's will. In Christianity, the will of God is that which can be gleaned from the Bible and from the interpretation of Church teachers and thinkers. For Augustine, war is seen as necessary to punish evil, an unavoidable consequence of human sin, and it is viewed as impossible that a human being could never sin. Augustine allows wars to avenge injuries, to punish a wrong done by the citizens of another state, for the return of property, and for moral compensation. Peace is an impossibility for Augustine, until the Second Coming of Christ at the end of human history. Therefore, the state is necessary to maintain peace. War is even glorified as a manifestation of God's love for mankind as it is for the good of humanity. Soldiering and obedience to political authorities are seen as necessary for Christians, thus support for wars is perhaps more likely in Christian states where strict followers feel compelled to offer their support to the government's political strategies, including war, because of their faith. 
In Advaita Vedānta, there is much less emphasis on cosmology than in the JudeoChristian tradition. Ontology is more important than cosmology because Advaita is concerned more with explaining the ultimate reality logically presupposed by the world than asking why or how the world originates. Śankara even advises that creation stories not be taken literally. Rather than causing the universe to occur from nothing, Advaita sees creation as matter pre-existing within the creator. This is because Advaita asserts no "beginning" to creation in contrast to the linear time conception in Christianity. From a standpoint of reality, there is no creation and there is no creator God (Sharma, The Philosophy of Religion 5-6). However, Brahman, the ultimate reality (also called Íśvara) is seen as the cause of the universe. There is no subordinating of women in the account of creation, and as R.K. Chatterjee explains, in Vedic times, the position of women was high and they were generally treated as equals with men. Especially in South India, societies tended and still tend to be matriarchal in contrast to the strict patriarchy of the Abrahamic faiths. The Rg-Veda, unlike the Bible, contains hymns by as many as twentyseven ascetic women seers called Brahmavädinis. Both girls and boys had upanayanathey wore the sacred thread. Girls had the freedom to marry, or to remain unmarried. It was only with the smrti texts such as the Laws of Manu that the position of women deteriorated (Chatterjee 64-65).

For Hindus, the imperfection of man is not caused by a Fall, but by ignorance. This ignorance is seen as the root cause of suffering and pain, and all other evils are said to flow from it. Advaita Vedanta, however, argues that a loving and good God could not have created the universe because the universe contains evil and God is not an agent of evil - God is beyond good and evil. Two standpoints exist in Vedānta. The absolutist 
argues that evil does not exist, and neither does good. Evil is an illusion, and so there is no need to see the evil occurring thought history as a dark, menacing and crushing force. The relativist argues that it is the karmas of the jivas and not God that causes evil, and this evil is real. However, this was no beginning to the cycle of birth and rebirth (saìs $\bar{a} r a$ is anādi). This prevents any ideas of the first created souls experiencing happiness or misery owing to non-existent causes such as Original Sin (since they were never born). Evil therefore is a result of karma (Sharma, The Philosophy of Religion 2527). Evil exists because of the constructions the human mind puts on the objects of creation. People create value judgments for certain objects or certain people, and this is the cause of misery in the world. As Sri Ramana Maharshi says: "It is the human mind that creates its own difficulties and then cries for help. Is God so partial as to give peace to one person and sorrow to another? In creation there is room for everything but man refuses to see the good, the healthy and the beautiful" (qtd. in Godman 210). Because of this perception, the problem of evil is never directly confronted in Hinduism. Evil is seen as primarily a metaphysical issue rather than a moral one. As a moral issue, it is tied to karma, and cosmologically, karma has no beginning (Sharma, The Philosophy of Religion 30-31), ${ }^{114}$ and therefore, at least implicitly, there is no "problem of evil".

The idea of reincarnation does situate the realm of the soul outside of space and time because of the notion of immortality of the soul. From a Biblical perspective, the soul is seen as being created along with the physical body by the parents (traducianism) which supports the idea of the transmission of original sin. Alternatively, the creationism

\footnotetext{
${ }^{114}$ Hinduism does not really try to offer solutions to where karma began, "for it takes for granted that there was a time when the self was without any disposition $[$ karma $]$ whatsoever. Such a view of the self is an abstraction as meaningless as that of mere disposition which characterizes no one. The self, as ordinarily known to us, always means a self with a certain stock of disposition; and this fact is indicated in Indian expositions by describing karma as beginningless (anāndi)" (Hiriyanna 27-28).
} 
view is that God creates a new soul when a human being is conceived. With either definition however, there appears to be a finite beginning to our existence with begins at birth or conception. In Hinduism, a soul would have to exist prior to conception. ${ }^{115}$ The Indian conception of time employs much larger units and the universe is said to dissolve and reappear. For this reason, Indian philosophy does not accord to time a central place in its ontology, although it does not ignore historicity completely. In Advaita Vedānta time, space and even causality is unreal in a deep metaphysical sense. The result of this is Indian philosophers did not confine their thinking to a particular society nor did they want to confine their thinking to a specific period or race. If philosophy is concerned with ageless, eternal truths and values, the need for a concern with history and historicity also disappears. There is less of a tendency to view all the wars in history as having some kind of purpose and leading to the final end of history, thus wars are not seen as merely inevitable, either for teleological reasons or because of a sinful human nature.

\section{Conception of God}

Christianity holds a belief in one God, who is supremely good, omniscient, omnipotent, incorruptible, inviolable and immutable. Monotheism itself may incite violence because it creates a division of Us (who believe) and Them (who do not, or who believe falsely). ${ }^{116}$ Regina Schwartz locates the origin of violence in this identityforming aspect of monotheism that creates imaginary boundaries between peoples

\footnotetext{
115 Some state that a soul has to go through 8,400,000 previous incarnations before it can be granted a human body $-2,000,000$ as a plant, 900,000 as an aquatic creature, 1,100,000 as an insect, 1,000,000 as a bird, 3,000,000 as a cow, and 400,000 as a monkey (Organ 121, note 27).

${ }^{116}$ I do not imply that this view is the only view, merely $a$ point of view. Hans Kung for example claims that the world was full of violence associated with religion long before the emergence of monotheism and that there is no evidence that violence associated with religion has increased since the arrival of monotheistic faiths (Kung 255).
} 
(Schwartz 5). Also, victories in battle are equated with having the true faith as the only God around is supporting one's own side and allowing the enemy to fail. Old Testament texts, which Christianity inherits from Judaism, paint a picture of God siding with the righteous nation of Israel and destroying Israel's enemies, and also of destroying Israel when it becomes unrighteous (e.g. the cases of Joshua and Gideon). God freeing the Israelites from Egyptian bondage may incite other oppressed people to fight believing that God sides with those who are oppressed. As Radhakrishnan observes:

The intolerance of narrow monotheism is written in letters of blood across the history of man from the time when first the tribes of Israel burst into the land of Canaan. The worshippers of the one jealous God are egged on to aggressive wars against people of alien cults. They invoke divine sanction for the cruelties inflicted on the conquered. The spirit of old Israel is inherited by Christianity and Islam, and it might not be unreasonable to suggest that it would have been better for Western civilization if Greece had moulded it on this question rather than Palestine. Wars of religion which are the outcome of fanaticism that prompts and justifies the extermination of aliens of different creeds were practically unknown in Hindu India. (The Hindu View of Life 36)

Radhakrishnan points out that Hindu and Buddhist rulers of India took in those who were religiously persecuted - Jews, Christians and Zoroastrians - and these were given absolute freedom. In contrast, Christian rulers expelled Jews and Muslims from Spain in 1492, Russia had anti-Jewish pogroms in the nineteenth century, and Hitler tried to execute his "final solution" on Jews during World War II.

The New Testament presents a God who takes human form and dies for the sins of humanity in order to save them. The coming down of God in human history to directly intervene in the lives of humans is seen as a unique quality of Christianity by believers. At the beginning of the Christian movement, recent converts blamed Jews for the murder of Jesus, and this eventually fuelled anti-Semitic predilections amongst Christians for 
centuries causing wars and violence against Jews. Perhaps the New Testament attempted to end conflicts based on ethnicity (see Galatians 3:28 - "There is neither Jew nor Greek") but instead, it exchanged ethnicity for faith as a marker of difference. The ingroup are fellow Christians, who also are saved and are granted eternal life (see John 14:6 - "No one comes to the Father except through me"). Those who do not believe are destroyed (see Matthew 25:41 - "Then he will say to those at his left hand, 'You that are accursed, depart from me into the eternal fire prepared for the devil and his angels"') (Avalos 133).

God is the sovereign over all beings because He created the world from nothing. In the Abrahamic faiths, there is a hierarchy of creation wherein man is placed as master of all of creation by God. God is depicted as anthropomorphic, and man is said to be made "in God's own image", which not only increases ideas of an anthropomorphic God, but also creates a radical anthropocentrism. ${ }^{117}$ Drewermann locates the belligerent effects of Christianity's attitude in the Biblical portrayal of God as physically and psychologically anthropomorphic. Anthropocentric ideas increase with the Christocentrism of the New Testament as the notion that God became incarnate for the sake of humans sets humans theologically even more firmly in the centre of the world. The individual becomes increasingly important, and unlike with the Hebrews and the Romans where God was expected to be concerned about the welfare of a nation, Christianity portrays God as being concerted with the fate of every individual. This metaphysical centralising of man in creation led Christianity to reject reason and the insights of natural

\footnotetext{
${ }^{117}$ Of course, many esoteric beliefs exist within Christianity in which formless conceptions of God exist alongside with exoteric view. However, Smith implies that in Christianity, exoterics far outnumber esoterics, which would support my view that Christianity's anthropomorphism is more radical (Smith 28$31)$.
} 
science in preference to its own worldview from divine revelation. All of nature itself is seen as being subordinate to human beings. This anthropocentric worldview has devastating effects on both the treatment of non-humans and humans. It fosters an attitude of fear, violence, and exploitation toward external nature, as evidenced, for example by the inhumane treatment of animals in the Western world. ${ }^{118}$

Drewermann characterises Christian psychology as one of fear towards God, to whom we have to humbly bring petitions. In the Old Testament, God is portrayed as an angry God who metes out terrible punishment swiftly, and who therefore must be feared. The ultimate punishment that Christianity promises those who are evil in this life is to be cast into Hell, which is a permanent state of being outside of a relationship with the creator. It is a fear of the afterlife, the fear that ultimately one's existence will be insignificant, and a theological fear of losing God that is always a motivating factor for Christians. These fears find expression in war when one questions one's own significance or the survival of one's cherished notions whether they be ideological, nationalistic or about the preservation and claim of perceived rights. When one is threatened, the only desire is to see the rival dead.

Hinduism believes in the reality of one supreme universal spirit, existence, consciousness or sacred power (Brahman). However, descriptions of God tend to be more mysterious than in Christianity. The individual soul (atman) is synthesised with Brahman - the atman is the God immanent, and Brahman is the God transcendental. Brahman is therefore not only the "Great Self" present in a timeless reality, but it is also the individual self once it is liberated from its mortal bonds. Unlike the Judeo-Christian

\footnotetext{
${ }^{118}$ By contrast, the Aśoka's public welfare measure are said to have extended even to animals on the roads, and he constructed veterinary establishments. He even ended hunting expeditions (which were often used as group-building training exercises for an army) (Roy, Ethics of Warfare 56).
} 
God, Brahman does not interfere in the affairs of the world. Brahman does not punish, reward, cause good or evil, does not love or hate, nor is the source of morality. Advaita Vedānta recognises that knowledge of Brahman can only be partial. The existence of the Self (ätman) itself is offered as proof for the existence of Brahman (Rambachan 52). Therefore, in order to know God, one must know the Self. The essential knowledge (viśeșa jñana) is to understand that the Self is identical with the limitless Brahman.

Hindu devotees use expressions such as 'Divine Darkness' or 'That of which nothing can be said' when describing God (Radhakrishnan, The Hindu View of Life 12). ${ }^{119}$ Yājñavalkya uses the term neti neti ("neither this nor that") as a way to help understand the nature of God by first understanding what is not God. The human being is a person (purușa), but God is the perfect personality (uttama purușa) - the supreme knower, great lover and perfect will - often depicted in the trimürti (the three forms which some correlate to the Christian Trinity) of Brahmā (creator), Viṣnu (preserver) and Śiva (destroyer). ${ }^{120}$ Unlike the Trinity, in which believers conceive of the distinct personhood (derived from the Latin persona meaning mask/character in a play) of Father, Son and Holy Spirit yet all are one substance, the Hindu views the three forms as three sides of one personality (Radhakrishnan, The Hindu View of Life 13). However, far more descriptions of God occur, and they take on multiple names and multiple personalities in order to depict the multifaceted nature of God - they are just concrete representations of the abstract. When the sage Yājñavalkya was asked to state the number of gods, he

\footnotetext{
${ }^{119}$ The Kena Upaniṣad 1:3-9 describes Brahman as "that which cannot be expressed by speech, but by which speech is expressed; that which cannot be apprehended by the mind, but by which, they say, the mind is apprehended; that which cannot be perceived by the eye, but by which the eye is perceived; that which cannot he heard by the ear, but by which the hearing is perceived; that which cannot be smelt by the breath, but by which the breath smells an object."

${ }^{120}$ As an easy mnemonic for God, Hindus sometimes learn of the trinity as being Generator, Operator/Organiser and Destroyer.
} 
started at 3306 , but eventually said, "This indestructible enduring reality is to be looked upon as one only" (Bṛhadāraṇyaka Upanișad, iv.4.30). Though anthropomorphic conceptions of the divine exist, ${ }^{121}$ one must note that Hindu gods appear to be far more fantastical than the Christian idea - they have multiple limbs, various skin colours, have animal parts fused with them, have various animal vehicles and companions, etc. - which serves to reduce anthropomorphism, and perhaps to reduce postulations of personality of the divine (see Radhakrishnan, The Hindu View of Life 16). Unlike the Christian incarnation, Hindu avatars do not contribute to anthropomorphic or anthropocentric views of God because the nature of the avatar is never fully human as Jesus was said to be (see Tripurari 204). Moreover, avatars are not sacrificial victims, which consequently does not generate undue empathy for victims.

\section{Potential questions for empirical testing}

Some potential questions which could arise from studying the connection between warfare and models of the past are: Do anthropomorphic conceptions of the divine influence one's thinking about what is the will of God regarding enemy soldiers? Does monotheism increase the conceptual differences between Self and Other by creating ingroups of co-religionists and labelling of non-believers as outsiders? Does belief in a personal God who intervenes in the affairs of the world affect how one explains world events, and are these explanations different from atheist beliefs or beliefs in impersonal,

\footnotetext{
${ }^{121}$ For example, the Hindu "gods interact with humans, give them weapons, influence the outcome of battles, make love with the queens, and so on" (qtd. in Roy, Ethics of Warfare 15).
} 
non-interactive divinities? Does belief in a linear Christian conception of time affect impetus to effect change in the world? ${ }^{122}$

\section{Where are we going? (Prediction - a model for the future)}

Christians believe that each soul is a unique creation that forms part of the human being at the time of their conception/birth. At the end of a human's life, four possibilities have been proposed for the journey of the soul: heaven (if a good life has been led), hell (if one has led a life of sin), purgatory (a place of purification before entering heaven) and limbo (for unbaptised babies). (The latter two options have been more controversial and even denied by some Christian denominations). The end state for the soul is based on judgment for the actions and beliefs held in one's life. In Hinduism, similarly, four options exist: the soul could go to a temporary state of bliss, or a temporary state of punishment, it could return to earth and be reincarnated, or it could achieve liberation and become one with Brahman. If reincarnated, the soul is subject to the law of karma. Beliefs held in one's lifetime are not a factor which determines where the soul goes after death, although one's actions and adherence to one's dharma will determine the state of one's soul after death.

\footnotetext{
${ }^{122}$ This last question has often been phrased as a statement to offer an explanation particularly for American support for the state of Israel. From a Biblical perspective, one of the signs of the end times is thought to be the return of the Jews to Israel (along with the reconstruction of the Temple). American Evangelicals especially tend to be pro-Zionist in an attempt to help usher in the second coming of Christ. Pro-Zionist tendacies include supplying weapons to Israel or supporting Israel in its wars with its Arab neighbours.
} 


\section{Comparative analysis}

Both Christian and Hindu religions recognise the existence of some dimension of the human which survives bodily death ${ }^{123}$ and is beyond space and time - that is, belief in a soul. But both differ in their ideas of what happens to the soul after death. In Christianity, the afterlife and the fate of the world as a whole is structured around the idea of being saved, which in turn is centred around belief in the death and resurrection of Jesus. Many Christian denominations, because of their interpretation of Paul (see Ephesians 2:8-9), believe that salvation is by grace alone, through faith alone, in Jesus Christ alone. If we were responsible to save ourselves and keep ourselves saved, we would fail. Perhaps the one item of Christian faith which is non-negotiable is the belief that Jesus Christ provided eternal freedom for mankind through his death and resurrection.

There are some different paradigms of salvation in Christianity, but the one that is most influential in Augustinian Christianity is the Roman Catholic understanding of salvation that after the Fall, humanity did not become totally corrupt but was "wounded by sin" (rather than destroyed). The only thing that can save humanity is an act of God, so Jesus had to die to save us from the bondage of sin. But, one must believe in this saving act of grace in order to be saved. One consequence of this soteriology is that

\footnotetext{
${ }^{123}$ In addition to the belief in the immortality of the soul, Christians also profess a resurrection of the body. This does not mean the resuscitation of a corpse, but rather the re-creation or reconstitution of the psychophysical individual that will inhabit a spiritual world as the physical body inhabits the material world. Therefore, there is an idea of survival of personality to enjoy either eternal rewards or eternal suffering. This reinforces the idea of the importance of the individual by projecting individual personality into the afterlife. The basis for this is the fact that the Second Coming of Christ did not occur immediately after Christ's death, therefore, a postponed eschatology evolved emphasising ideas of Heaven and Hell (Hick 125-26). Perhaps, the importance of correct action and correct belief become further emphasised if one believes that the afterlife will reflect a society like the present; present virtue (like joining a Crusade) may result in greater states of reward in the next life. From an Advaitan perspective, seeking mokșa involves extinguishing one's personality.
} 
unbelievers, non-Christians and those in opposition with Church views were thought of as being doomed to hell. Demonising one's enemies in this way would make fighting them easier to justify. Baptism was elevated to a powerful sacrament which removed the stain of original sin, and therefore, at least opened the doors of salvation to baptised Christians. ${ }^{124}$ In modern times the Catholic Church especially has taken great strides in its theology by officially declaring that it did not teach that people who do not believe in Jesus will not be saved. Especially after Vatican II, the idea put forward is that the salvation that Christ won was universal, and even ideas of freedom of religion exist. However, this was certainly not the case of the Church in the time of Augustine or Aquinas. Holy wars, crusades and inquisitions were started to convert non-Christian, to punish church dissenters or to free Christian lands from the control of non-Christians. ${ }^{125}$

Hinduism does not profess any specific creed and is not as concerned with orthodoxy as Christianity, especially in its idea of what it is meant to be saved. As Radhakrishnan says:

\footnotetext{
${ }^{124}$ It was Augustine who elevated baptism to this sacrament of removing original sin taking his lead from the words of Jesus: "I solemnly assure you, no one can enter into God's kingdom without being begotten of water and Spirit" (John 3:5). It is worth noting that for Augustine, even babies who were unbaptised were subject to eternal punishment, although he conceded that their punishment would be the mildest of all (see Augustine, De peccatorum meritis, I, Chapter 21, XVI). This was later altered to the idea of "limbo"some other place of ignorant bliss that is neither heaven nor hell. Fortunately, these Augustinianinfluenced ideas were eradicated when on April 22, 2007, the Vatican's theological commission published a report entitled "The Hope of Salvation for Infants who Die without being Baptised" in which unbaptised children were no longer doomed to limbo. What this did, by extension, was to no longer condemn all unbaptised people, instead proclaiming a message of universal salvation. What is also interesting is the following statement in this document: "72.a) The warfare and turmoil of the 20th century, and the yearning of humanity for peace and unity, shown by the founding of, e.g., the United Nations Organization, the European Union, the African Union, have helped the Church to understand more deeply the importance of the theme of communion in the Gospel message and so to develop an ecclesiology of communion" perhaps an indication of politics influencing religion for a change?

( $<$ http://www.vatican.va/roman_curia/congregations/cfaith/cti_documents/rc_con_cfaith_doc_20070419_u n-baptised-infants_en.html $>$ ).

${ }^{125}$ Note, for example that the Roman Missal pre-1962 included in its Good Friday Intercession a prayer for the conversion of the "perfidious" Jews. In recent times, thankfully, references to the "the murderers of God", "the lawless nation of the Jews" and "immersion in darkness" have been removed, but, nonetheless, the Good Friday Intercessions include a prayer that Jews will acknowledge Jesus, and that those who do not acknowledge Christ will similarly be led by the Holy Spirit to acknowledge Him (Marshall).
} 
Hinduism is wholly free from the strange obsession of some faiths that the acceptance of a particular religious metaphysic is necessary for salvation, and non-acceptance thereof is a heinous sin meriting eternal punishment in hell. [...] It is not fair to God or man to assume that one people are the chosen of God, that their religion occupies a central place in the religious development of mankind, and that all others should borrow from them or suffer spiritual destruction. (The Hindu View of Life 21,32)

In Hinduism, instead of the idea of salvation is the concept of mukti or mokșa which may be translated respectively as release or liberation. In Advaita Vedānta, mokșa can be obtained through either of four paths or methods (yoga): karma yoga (acting rightly through selfless service), bhakti yoga (devoting one's self and love to a deity), rāja yoga (cultivating the mind through meditation) and jñana yoga (obtaining knowledge of the absolute) ("The Four Margas"). At liberation the illusions and delusions (based on a false identification with matter) which have driven the process of successive reincarnations are seen for what they are, as $m \bar{a} y \bar{a}$ (illusion). Beings which are subject to eternal transmutation (the endless process of birth, aging and death) cannot be said to truly exist - their apparent reality is only an illusion based on a relative understanding of the bigger picture. This ultimate release from matter gives rise to a feeling of infinite freedom and bliss (ānanda). Immutable existence (sat), pure consciousness (cit) and bliss (annanda) are considered characteristics of ultimate reality (Brahman) as experienced by the saint. The Advaitic position also has ideas of heaven and hell, but they are temporary states, and therefore, heaven is never man's final goal, but only a prelude to a better incarnation which will bring a person closer to mokșa (Zaehner 23-24).

One of the key elements of Hindu belief is the law of causation known as karma. Karma is a way of explaining inequalities in the world, that our actions in this life will 
condition the circumstances of existence in the next. This makes inequalities the responsibility of the individual not the Creator. Unlike Christianity in which a soul enjoys two lives, one in this world, and one in the afterlife, in Hinduism, there is the potential for thousands of lives, both on earth and elsewhere. ${ }^{126}$ It is not God who binds one man and frees the other, but it is man himself because of his past actions in previous lives. Breaking this cycle of death and rebirth only comes when the individual ego ceases to exist and with it, attachment to the fleeting desires of a temporary material world. Because escaping the cycle is an exercise in individual development, Hinduism, from an Advaitan viewpoint tends to be very anti-ritualistic and non-dogmatic, and all varieties of ritual practice are tolerated, thus avoiding holy wars, and reducing the potential for demonising the enemy in warfare.

Karma is one way that violence is meted out to individuals where the agent of the violence is the individual's own past life. Perhaps in doing so, from a Girardian standpoint, Hinduism silences the voice of the victim and conceals the scapegoat mechanism by marginalising certain groups of people from society. ${ }^{127}$ The idea of karma

\footnotetext{
${ }^{126}$ See Tony Walter, Helen Waterhouse, "A Very Private Belief: Reincarnation in Contemporary England", Sociology of Religion (1999) 60 (2): 187-197. The authors concluded that belief in reincarnation was shown to have no impact on a person's behaviour and choices and that like modern Catholics and Protestants who no longer believe in an eternal Hell, those who believe in reincarnation also have a benignly pleasant anticipation of what awaits them in their future life. This would be an interesting idea to test in other countries, such as the United States, but first one would have to verify how many Christians no longer believe in the idea of an eternal Hell.

${ }^{127}$ Although, as has already been discussed, the kind of marginalisation that people like Gandhi would have seen it is not the social marginalisation of untouchability. The varna class system was originally one that delineated social functions, each function being seen as equally important for the whole of society. After all, even a Brahmin needs someone to construct his funeral pyre and dispose of the remains of his cremation - a task generally done by the lowest Domar caste. The caste system and the political domination that it brings with it are seen by many modern researchers as the result of Western influence on the varna system (cf. Nicholas B. Dirks, Castes of Mind: Colonialism and the Making of Modern India, Princeton, NJ: Princeton University Press, 2001). One should bear in mind that inter-caste violence and discrimination often occurs in India, Pakistan and Bangladesh even amongst Christian and Muslim communities. This perhaps indicates that caste has become a cultural institution rather than a true interpretation of any Hindu doctrine.
} 
might lead a Hindu to avoid direct violence in order to advance the journey of their own soul to liberation. Karma acts as an impersonal mimetic substitution for violence, therefore having no need for a scapegoat mechanism. Neither God, nor one's neighbour is blamed as karma is seen as ethical because one only has oneself to blame. This even contributes to an absence of any feeling of bitterness on the part of the misfortunate in India (see Hiriyanna 381), which might reduce levels of violence including the incidence of revolution against the ruling classes.

\section{Potential questions for empirical testing}

Some potential questions which could arise from studying the connection between warfare and the afterlife are: Does the idea of eternal bliss or eternal suffering affect a combatant's action on earth? Does the promise of eternal reward caused by martyrdom affect a combatant's potential for risk-taking in warfare? What are the effects on risktaking if one believes that the final destination for one's soul is not determined by actions in this (one) lifetime? Does belief in reincarnation affect ideas of empathy towards enemy militia?

\section{What is good and what is evil? (Axiology - theory of values)}

Since warfare is the question that is being looked at, what must be examined is how warfare is viewed by each worldview. In Augustinian Christianity, warfare is seen an inevitable consequence of the human condition and the fallen nature of mankind. War is a remedy, and political leaders are encouraged to be obeyed, being seen as proxies for the divine. The Bible presents many images of warfare as a triumph over evil, and God 
himself is an active participant in the destruction and bloodshed. In Hinduism, while war is often mentioned, recourse to war as a political strategy seems to have been restricted in a far more stringent manner than Christian jus in bello rules, and wars tended to be less decisive. ${ }^{128}$ The most influential scripture, the Bhagavad Gītā seems to use an allegory of war to deliver a spiritual message to humanity. War itself, although not outlawed, is neither remedial nor necessarily inevitable. Gandhi's non-violent solution to the problem of British colonialism has been greatly influential in increasing and promoting nonviolent interpretations of the Hindu worldview.

\section{Comparative analysis}

Most religions, including Christianity and Hinduism answer questions of good and evil by consulting their sacred books. The implication of sacred texts will be discussed further in Section 6, which deals with knowledge. This section will instead look at how each religion has justified the need for the state (in maintaining order and fighting evil), and how each religion has justified when the state could use violence, including going to war. Each philosophy has striven to create rules for the declaration of war and to structure fighting in a way that seemed most equitable to them.

Christianity has an ambivalence to earthly monarchs, as Jesus presents the image of a king as one who is humble and who washes his disciples' feet. Yet, Christianity does seem to encourage that its believers subject themselves to governing authorities

\footnotetext{
${ }^{128}$ For example, as already discussed in Chapter 3, Hindu conquerors were supposed to adopt the way of life, dress and customs of the lands they were conquering. No such idea would have ever occurred to Augustine. If pagans were conquered, converting them to Christianity and bringing them under the rule of Mother Church had to be part of the long-term solution. US wars to bring democracy (part of the American way of life) to other countries would be regarded as an infringement of the Hindu rules of engagement, and possibly of International Law as well, but for the Americans, bringing democracy and Western-style human rights is seen as a just cause and therefore a just war.
} 
because God established them. This stretches the previous idea of Jewish just wars as those being specifically ordered by God to Christian just wars as those being ordered by earthly rulers as a proxy for God. Christianity encourages praying for political leaders. The state is seen as necessary to keep evil in check, to minimise disorder and to allow citizens to reach God. It is responsible for a judiciary and for correcting wrongs and punishment. Wars are part of a divine plan because the earth is not enduring; only the Eternal City endures forever and is peaceful forever. In Augustinian Christianity, war is even viewed as an act of love by God and an act of chastisement for the wicked.

The idea of legitimate authority, important in the Christian just war theory, can perhaps be traced to early ideas of holy war as they are presented in the Bible. The holy war myth envisions a prophet/leader with divine knowledge which authorises him to wage war with religious justification. Those who follow the prophet-king into battle are promised reward and blessings. The just war has incorporated this idea replacing the prophet-king with secular kings, presidents or generals who have special knowledge to know when their war is just (- recall George H.W. Bush appealing to his heavenly father for advice). In these wars, soldiers who die for their countries do not die in vain but in the name of freedom. Perhaps this results in a self-replicating meme - "God and country" - a notion which reassures people ${ }^{129}$ that there is a divine purpose to political life (Fiala 17-18).

\footnotetext{
${ }^{129}$ Fiala is referring here to Americans, but this argument can be made for all Christian-influenced nations. Tied to this faith in authority is the idea of American exceptionalism - the idea that God has a special providential plan for Americans. This plan may include spreading democratic values. Thus American victories become mythologised as democratising wars of freedom, and such mythologies continue to inspire new generations of Americans to join the US military - a military with an overwhelmingly Christian ethos. Thinking about America as a nation "under God" or presidential speeches ending with "God Bless America" bring home to Americans the idea of war as a necessary sacrifice for American values (Fiala 19). Therefore, the connection of ideas of a "just war" to Christianity should not be underestimated in a world where American military influence continues to dominate (cf. Brett Wilkins,
} 
Much as in the West, the State was regarded by Hindus as an essential instrument to secure the existence of the people. Social order involved both the horizontal division into stages of life (äśramas) and the vertical division of classes (varnas). In this division, the kșatriya householder, under control by the king, was expected to protect all other classes. The King has a duty (dharma) to create a kingdom of peace and prosperity, and his most important task was the administration of justice (dand $\bar{a})$. Unlike the Christian context of the divine right of kings, in Hinduism the king is divine not because he is a god in human form but is divine through the act of protecting the lives and properties of his subjects along with the varna of society. Only if the king observes dharma and is righteous he is a divine monarch. He ceases to be divine if he fails in his duties (Roy, Ethics of Warfare 76).

Unlike in Western philosophy, there is no distinction between jus in bello and jus ad bellum, nor are Hindu writers interested in matters of right authority, which is so important in Western just war discourse because Hindu thinkers made no distinction between private duels and public violence or between internal and external enemies. One reason for this lack of distinction is because the polities themselves were amorphous structures with fuzzy territorial borders. The power of various kings overlapped and interpenetrated making it difficult to neatly differentiate internal affairs with external ones (see Brekke 59, 61, 80,113, 115, 119). Perhaps jus ad bellum considerations do not play such a primal role in Hindu thinking about war because although the brahmanical social order seems to have a dualism of Church and State (by its differentiation of the ruling/fighting kșatriya and the teaching/sacrificing Brahmins like the kingdoms of

\footnotetext{
"The Christianization of the US Military in the War on Terror", Moral Low Ground, January 9, 2011, $<$ http://morallowground.com/2011/01/09/the-christianization-of-the-us-military-in-the-war-on-terror/>).
} 
medieval Europe), no distinction is ever made between secular and religious concerns. Both are linked and both are seen as necessary for the fulfilment of the individual. As a result, just war thinking did not develop because the general ethics of religion were always expected to be adhered to as the political was not separated from the religious.

Hindu war theories do have distinctions between dharmayuddha and kutayuddha, but often these terms are interchangeable and Indian political history seems to reflect a constant struggle between what kinds of warfare are acceptable. Certainly, what was not acceptable were religiously motivated or religiously justified wars against foreigners or against people of other faiths like the Christian concept of "crusade" or the Islamic concept of "jihad" (the lesser outer al-jihad al-asghar). In other words, there is no idea of a "holy war". The kingdoms of India were not defined in terms of a loyalty to a single religion, culture or ideology, nor were they monolithic empires. Rather they were extension of hegemonic control - a structure for the maintenance of power and to maintain security against internal and external threats.

Some state that it is because of the many jus in bello laws that Hinduism has a theory of just war that is comparable with the West. They cite the Laws of Manu as well as texts like the Arthaśastra (see Subedi). However these texts are relatively more recent than the śruti texts, and the Laws of Manu were not followed by the majority of Hindus in their history. I do not think that an examination of smrti texts alone is conducive to an understanding of the Hindu philosophy regarding war, since the basis of Hindu philosophy lies in the teachings found in the Bhagavad Gìtā which dominates Hindu thinking and forms the basis for Hindu ethical positions. An allegorical reading of the Bhagavad Gītā, which is supported by many commentaries and Hindu thinkers, indicates 
that it is not a manual for warfare, but that its main purpose is to convey mystical knowledge. If this allegorical approach is used, war in the Bible (especialy in the Old Testament) is considerably more visible than in the Gìtā.

Potential questions for empirical testing

Some potential questions which could arise from studying the connection between warfare and models of axiology include: Are religions with a clerical hierarchy more prone to being swayed by dictators and the charisma of a single figure-head/leader? Do individuals with worldviews which include war-filled foundational texts (such as scriptures) condone warfare more than people whose foundational texts do not contain as much warfare? Are societies with polytheistic worldviews more peaceful, more accepting of the Other, more tolerant of oppositional or different viewpoints than societies with monotheistic views? Do worldviews which do not claim any monopoly on metaphysical truth produce less belligerent devotees?

\section{Theory of action, or praxeology (How should we act?)}

Christian action is centred around the idea of love. Christ charged everyone with loving his neighbour, which is interpreted as loving everyone. Augustine saw war as an act of love, by God, for the greater good, or an act of love by man to compel others to be good. Religious leaders and political leaders are looked up to as authority figures, as quasi proxies to the ultimate authority of God himself. Mother Church is viewed as the most important moral compass. In Hinduism, correct action lies in conforming to one's dharma. Ideas from religious leaders for the everyday layperson are less important 
because it is the individual's own renouncement which results in mokșa and not the priests'. ${ }^{130}$ Ideas from political leaders are even less important; the whole idea of legitimate authority is much less of a concern in Hinduism.

\section{Comparative analysis}

The most important theory of action in Christianity is the Golden Rule given by Christ: "In everything do to others as you would have them do to you; for this is the law and the prophets" (Matthew 7:12; also Luke 6:31, 10:27; Galatians 5:14). In Christian just war thinking, actions of just warriors are characterised as actions of love. Every man is charged to love his neighbour, and a neighbour is seen as all of mankind. This is why Christians actively seek converts. For Augustine, war which was an act of God, was a manifestation of God's love for mankind for the good of humanity. It is a means of chastisement and correction, and to train people to lead a more righteous life. War is a way of compelling someone to good, through the act of sacrifice that being a warrior entails. By killing unjust warriors, the just warrior is preventing further sin, and sin is a great injury to the soul - death injures only the body. By engaging in war, you are forcing the non-believer, or the errant Christian to submit his will to the will of God. The command to love one's neighbour is not so much for the sake of the neighbour, but for the sake of God - for the sake of the soul of the neighbour not his body. In addition, caring for the soul involves orthodoxy about Jesus Christ. As Andrew Bernstein states, in

\footnotetext{
${ }^{130}$ For those individuals seeking religious instruction from a guru however, Hinduism does have a respect for authorities of religion in its ancient and long-standing guru-śisya paramparā tradition which respects the lineage of teachers. Note that knowledge is of greater importance in Hinduism than Christianity which places a greater emphasis on obedience (Gier). However, knowledge is only one way to liberation.
} 
Christianity, faith-based orthodoxy is more important than human life. Bernstein explains:

There's [sic] only 2 ways to deal with human beings: you deal with them by reason or you deal with them by force. There's no other possibility. And with reason subordinated to faith [as it was in pre-Enlightenment Christianity], rational persuasion is subordinated to force. With rational proof abrogated, physical violence is necessitated. This is why the history of Christianity is the bloody spectacle that it is.

If faith-based orthodoxy is so important, people are more likely to support leaders even if it means spending treasure and blood to fight an extended war, because people believe that their leaders were selected for a divine purpose. Also, Christian soldiers, using Augustine, can rationalise war as being motivated by love for neighbour and because the consequences of sin give them no other choice. ${ }^{131}$ Hinduism places little importance on faith-based orthodoxy, there is less impetus to see leaders as being part of some divine plan, and perhaps less likelihood for the people to support the government's efforts in wars (at least, for wars that are not of an immediate, urgent and defensive nature).

In Hinduism, all action is undertaken bearing in mind the principle of dharma. Dharma implies a distinction between the acceptance of worldly life and social values, and renunciation (samnyāsa) (the rejection of worldly life) in order to achieve salvation or liberation $(m o k s ̦ a)$. It is a way for people of all castes and all backgrounds to feel dignity in whatever action they are doing (see Sharma, Modern Hindu Thought 89). ${ }^{132}$ One has to do what one's dharma dictates, however, unlike in Christianity, where just warriors are rewarded with heaven for their fighting, in Hinduism, all warriors, just or

\footnotetext{
${ }^{131}$ I think that it is important to note that this is a rationalising interpretive schema that few believe intellectually, but react to emotionally, even in our times.

${ }^{132}$ Unlike Christianity in which debates on action centre around what God commanded mankind to do, dharma is rarely ever connected to divine will or command (Gier).
} 
unjust are rewarded with heaven for their fighting because it is their duty to fight (Buck 367). Thus, even the enemy and the enemy king are not vilified as a personification of evil, thus making it seem that earthly battles reflect some great cosmic struggle between good and evil. Although historically revelation was prioritised, in Hinduism as practised from the nineteenth century onward (especially by the educated and cosmopolitan elites), it is conscience and common sense that are given the most priority. ${ }^{133}$ This is best exemplified by Gandhi who, building on an earlier tradition in Hinduism, accepted the Vedas, but rejected that they were infallible. It is the spirit of the law that is more important than the letter of the law (Sharma, Modern Hindu Thought 91). Faith is not connected to adherence to authority in the same way as in Christianity, since Hinduism is seen as a personal path of the individual and not a collective sharing of identical dogmas as in Christianity. As. S. Radhakrishnan states, "Blind belief in dogma is not the faith which saves. It is an unfortunate legacy of the course which Christian theology has followed in Europe that faith has come to connote a mechanical adherence to authority" (The Hindu View of Life 4). Perhaps allowing for conscious-based interpretations of revealed texts (as Gandhi claimed to do) would contribute to reducing collective violence. As has already been discussed, it is the literal interpretation of scripture that plays a dangerous part in influencing both Christians and Hindus to justify warfare. Unfortunately, even amongst educated, cosmopolitan elites in the Christian world, literal interpretations of scripture based not on Biblical scholarship but on blind faith continue to be influential.

\footnotetext{
${ }^{133}$ This is also true of modern Christianity, although there are many Christian denominations which cling to an idea which was probably more common in the Middle Ages - that the Bible is the inerrant word of God. They rely on passages such as 2 Timothy 3:16-17 which says "All Scripture is breathed out by God and profitable for teaching, for reproof, for correction, and for training in righteousness, that the man of God may be competent, equipped for every good work".
} 
In contrast to the radical opposition of heterodoxy by Christianity, Hinduism has a radical inclusivity. Indian culture in general has absorbed from all who have come into contact with it. The Hindu idea of tolerance is one of the main ideas that contributes to peace. Tolerance for Hindus is not merely allowing but, in many cases, incorporating ideas from outside into their own tradition. Western religion is marred by its brutal intolerance because of the primacy accorded to orthodoxy, or right belief, because belief is so tied to ideas of salvation (Heard 54). Tolerating the ideas and insights of other religious traditions allows a man to change his character, not by coercion, perhaps supporting Andrew Bernstein's observation quoted earlier. The tolerance of Hinduism crosses boundaries of faith and culture, whereas the intolerance of Christianity to other beliefs undermines the message of universal brotherhood that Jesus appears to be teaching in the Gospels.

Radhakrishnan describes Hinduism as a missionary religion, but not in the spirit of proselytising, as in Christianity, with its mission to convert humanity to Christianity. There is a recognition that it is not belief, but conduct which counts. As a result, much like with ancient Roman religion, new deities and cults were absorbed into Hinduism (Radhakrishnan, The Hindu View of Life 22). All of humanity, with its diversity of communities, is said to be included in God's plan, and therefore all communities' beliefs are supposed to be respected. "To despise other people's gods is to despise them, for they and their gods are adapted to each other" (Radhakrishnan, The Hindu View of Life 26). Tolerance of other beliefs, however, is not to be confused with indifference. While recognising the capability of all revelations to explain reality, Hinduism still places those who believe in the highest revelation (of the Absolute) in a position of higher 
understanding (Radhakrishnan, The Hindu View of Life 30-31), however, it is less likely to lapse into exceptionalism as amongst some Christian (read: Western) politicians.

The mode of action for a Hindu should be one of detachment. Detachment reveals the nature of the world and the necessity of witnessing it rather than wallowing in it. In Christianity, it is the groups who have detached themselves the most from society (the Mennonites, Amish and Hutterites) who lack a theory of just war. Genuine detachment arising from mystical insight makes one aloof from the influence of material nature and it is thereby the basis of nonviolent life within God's play (BG 2.70-71). According to the Gītā, material attachments must be transcended because attachment to the fruit of one's work is the basis of exploitation and violence (BG 3.37). In order to guarantee the soul's life (real self), Hinduism asks that our identification with the material ego must die. If material ego died before every proclamation of war, think of the countless wars in history that would have been avoided. Unfortunately, Hinduism may be just as good as Christianity for hijacking the use of violence, as has been evidenced by the rise of Hindu nationalist militant movements in India. Some leaders like Tilak even found a way to use the Gītā to incite violence (although Tilak's approach to scripture is considered more of a fringe interpretation). However, for the most part, it is clear that these recent political developments are less about matters of religion (belief or practice) and more about concerns about identity, ideological historiography, political power, and economic share (see Ram-Prasad 526). 


\section{Potential questions for empirical testing}

Some potential questions which could arise from studying the connection between warfare and models of praxeology are: How do people's perceptions of their religion's stance on war affect their willingness to participate in, support or demonstrate against particular wars? What are the limits of violence for terrorists who specifically cite religion as the source of the inspiration for their violence? Note that both these questions rely on subjective ideas and may not reflect what scholars of those religions claim as the official viewpoint. ${ }^{134}$ Perhaps by better understanding the limits of violence, and also by understanding the divide between what religious scholars believe and what laypeople believe, better intrafaith as well as interfaith dialogue could be encouraged in order to arrive at more peaceful solutions.

\section{What is true and what is false? (Epistemology - theory of knowledge)}

For Christians, knowledge of God comes from the Bible - a small collection of texts which have been compiled into a canonical work - and (especially in the Catholic Church) also from tradition, through the on-going revelation of the Holy Spirit. It is mainly based on the exegetical powers of Church Fathers, bishops and popes. In the last few centuries, popes have even been declared infallible when preaching on matters of dogma and speaking ex cathedra. Biblical history is often conflated or combined with world history, and sometimes faith takes priority over reason, thus inculcating devotees with a sure certainty that what has been revealed by Christianity is the only possible fullness of Truth, all other truths being deficient. Reading the Bible as a historic treatise

\footnotetext{
${ }^{134}$ For example, Bishop Spong in his lecture "The Judeo-Christian Faith Story: How Much is History?" notes that even amongst educated Christians, who are doctors, lawyers and university professors, their knowledge of the Bible is at best at a Grade 4 Sunday school level.
} 
can often lead to literal readings of the Bible, which in turn lead to justification of warfare and violence. For Hindus, knowledge of the divine not only comes from a vast library of written sources, and through interpretation of gurus and rishis, but there is also the idea of doubt and uncertainty because the very nature of God is so incomprehensible by human perception. Hinduism allows for uncertainty, and also the use of reason. Many interpretations are allowed, and each is seen as valid rather than deficient. Again, this encourages tolerance of other beliefs by practitioners. Most interpretations of the Gītà tend to be allegoric ones.

\section{Comparative analysis}

For Christians, the primary source of knowledge about God is from the Bible because Christians believe that God shows himself to us through revelation. Christianity views its revelation, the Bible, to be the only correct source of revelation. There is a claim to superiority, which perhaps appears in all religions, but St. Peter is emphatic when he says "there is salvation in no one else [save Jesus], for there is no other name under heaven given among men whereby we must be saved" (Acts 4:12). This not only creates a "chosen people" mentality but it causes proselytising because converting people is seen as doing something good for their soul. However, history has demonstrated through Inquisitions and Crusades that radical proselytising and eradication of nonbelievers were interpreted as going hand in hand with the belief that there is no salvation outside the Church. ${ }^{135}$ Another bi-product of this worldview was colonisation and the forced conversion of foreign cultures as well as attempts made by Europeans to eradicate

\footnotetext{
${ }^{135}$ Smith says that this also exists today but only for a minority of Christians, whom he identifies as "evangelical Protestants of a fundamentalistic bent, conservative Catholics, and Orthodox" (Smith 14). How much of a minority this is is certainly questionable.
} 
non-Christian culture - what many would call a cultural genocide. This emphasis on right belief and an imperative to preach the News of Christ throughout the world (an especially Pauline influence) made Christianity a universal religion, representing a break with Judaism, similar to the way Buddhism split from Hinduism. Judaism and Hinduism are ethnic religions, which are grounded in lineage, language and history. They are not for other people. Both may accept converts, but they do not seek them (Smith 35). Christianity, though, not only actively seeks out converts, but historically, even resorted to baptising people and proselytising by force. Those who do not join are seen as evil and doomed to hell. As Guy Stroumsa states: "By right, the Christian community must include all mankind. A refusal to join the community of believers reflects a perverse and rather shocking vice" (emphasis added) (25). People who are labelled as evil make easier enemies to kill in battle. And this was not limited to non-Christians. This insistence on right belief was the cause of much religious conflict amongst the various sects of Christianity as well (Grant 155-71).

Divine knowledge comes from the Bible, which is seen as the word of God, therefore stories about war are conveying knowledge from God. Old Testament stories about war and violence abound in the history of God and His covenant with His chosen people. Augustine citing the Old Testament provided "the background to the idea that violence can be justified by God's direct command. And the risk is that when we believe that some human sovereign has divine authority for violence, it can make any atrocity appear to be the will of God" (Fiala 35). New Testament sayings are less explicit, with some sayings of Jesus or Paul that seem to condone war, and others that seem to condemn it. 
Old Testament stories over land disputes abound and God is seen committing genocide and ethnic cleansing to make room for his chosen people, and there is little attempt by Christian interpreters to say that these battles never occurred or were purely allegorical. Even pacifist Christian groups do not deny or allegorise biblical violence, "rather they might say that the Hebrews were acting under a different covenant that no longer applies to Christians" (Rosen 132). In the New Testament, Hector Avalos singles out the Book of Revelation in particular as a "revenge novel" for the violence it portrays against those who are not following Christianity in the manner approved of by the author (134). Revelation presents an imaginative array of modes of torture that await the enemies of Christianity. For this reason, he says that

[F]rom a secular critical perspective, the New Testament is even more violent than the Old Testament. In the Old Testament violence upon an individual lasts a finite amount of time - basically the lifetime of an individual. [...] Christianity, however, extends violence into the afterlife. Non-Christians will be tortured in hell forever (Revelation 20:15). Although many Christians believe in hell as symbolic, most traditional Christians have no problem in believing in the eternal torture of nonChristians in some literal fiery lake. (135)

Christians may be asked to pray for those who persecute them (see Matthew 5:44) but there is also the notion that God will exact vengeance on evil doers. St. Paul writes: "Beloved, never avenge yourselves, but leave room for the wrath of God; for it is written, 'Vengeance is mine, I will repay, says the Lord"” (Romans 12:19). "[T]he broader view of both the Hebrew Bible and the New Testament indicates that human beings or God can commit justifiable violence at some point on all of those that do not being to the respective in-groups" (Avalos 135). 
If interpreted literally, the Bible seems to advocate the use of violence in solving conflicts, and this can be sanctioned by God, or by human authorities. The Gītā also seems to support violence if one examines the text literally, although when one looks at the facts, literal interpretations seem historically untenable as it is said, for instance, that on the 80 mile circumference field of Kurukșetra, after 18 days and one night, $1,660,020,000$ men were said to have been killed and 240,165 men are said to have survived (see MB 11.26:9-19). ${ }^{136}$ Although the battlefield is memorialised in India today, the lack of burial grounds, memorials or other objects to document the war may indicate that it did not occur historically, nor could it occur within the realm of human possibility; however, (according to allegorical interpretations), the reality of the battle is the command by God that humans are to undertake a yogic battle in the homeland of the soul (Tripurari 208-11). However, the sheer number of violent incidents in the Bible is staggering, compared to the entire Mahābhārata, which is three times longer and mainly centres around one war. But, as Avalos states, "there is scarcely a book in the Bible in which violence is not either sanctioned, condoned, or just reported without value judgment" (140). And this violence is almost always justified rather than allegorised in the Bible compared to the Gîtā, where allegoric interpretations (especially from a Vedāntic point of view) are preferred over literal ones, although literal interpretations do exist. Of course, the reasons why the Judeo-Christian tradition has not allegorised

\footnotetext{
${ }^{136}$ Interestingly, the weapons used during the battle are said to have been bows and arrows empowered by mantras which produced a nuclear like weapon of mass destruction ( brahmāstra) - see Bhaktivedanta Swami Prabhupāda's commentary on the Śrīmad-Bhāgvatam 1.7.19<http://vedabase.net/sb/1/7/en>. Such weapons are said to be outlawed in the Laws of Manu. The number of people that died, if the numbers are taken literally, are said to be eight times more than the number of civilians and soldiers killed in all of the wars of the modern world combined including the American Civil War, Boer War, Mozambican War, Russian Revolution, Korean War, World Wars I and II and the Vietnam War (Tripurari 210 and endnote 27).
} 
passages that seem to encourage, condone or command violence lies in the way that salvation history is historicised as events in the Bible are also historicised. Christians see the wars and violence in the Bible as part of God's plan for man and they locate the actions of God in history in a way that Hindus do not. And Yahweh does not like Pyrrhic victories as at Kurukṣetra.

Christianity grounds its scriptures in history. The whole basis for the Christian faith is the resurrection was a historical fact, not just a metaphysical experience although this could be seen as being counter to reason. Drewermann notes that symbolism in Christianity became historicised, and because Christianity historicised its own mythology, is has always been hostile towards other religions which it views as mythology. Any resemblances of other faiths to Christianity were once viewed, in the best light as praeparatio evangelica, but in the worst as the work of the devil who wanted to mislead humans. Christians declared other religions to be based simply on mythology while its own version of the common motifs was defended as historically real (Beier 159). This redemption by Christ and the radical anthropocentrism it created ultimately led Christianity to reject the reason and progressive insights of the natural sciences or to interpret them within its old worldview.

In comparison with Christianity, Radhakrishnan explains how Hindu thought has no mistrust of reason, implying that reason does not have to be subservient to faith. Scriptures are said to register the intuitions of perfected souls - they describe general principles of religious knowledge and growth. This view does not ground Hindu texts in history therefore allowing for more plasticity in allegoric interpretations. Because of the range of experience, scripture records are many-sided (viśvatomukham) or suggestive of 
many interpretations (anekārthatām) (Radhakrishnan, The Hindu View of Life 5-6). The Hindu attitude towards the Vedas is also described as being one of trust tempered by criticism, and that theology should develop as science develops (Radhakrishnan, The Hindu View of Life 6-7). This is in stark contrast to the Dark Ages where even science, if it did not conform to scripture, was rejected causing violence over scientific discovery (e.g. Copernicus and later, Galileo) which would never occur in a Hindu worldview. Because Indian philosophers imagined the cosmos in terms of billions of years, unlike in the West in the age of Galileo, Hindus were not traumatised by the revelation that the universe was infinite and the human place in it is tiny (see BBC's The Story of India, Episode 4 - Ages of Gold). Once again, this kind of flexibility is part of the tolerance of the Hindu thinker to be able to readily admit other worldviews, and to consider them just as relevant as his own because of the recognition that the whole race of man is the offspring of God

"Hinduism does not distinguish ideas of God as true and false, adopting one particular idea as the standard for the whole human race. [...] Hinduism accepts all religious notions as facts and arranges them in the order of their more or less intrinsic significance" (Radhakrishnan, The Hindu View of Life 16). Ultimately, it is within the self where one sees God - the Absolute, however, Hinduism allows that multiple other conceptions are possible. ${ }^{137}$ This acceptance of various creeds would make any kind of

\footnotetext{
${ }^{137}$ Radhakrishnan, speaking for the Advaita Vedāntists, points out that those who worship the Absolute are ranked higher, followed by worshipers of a personal God, followed by worshipers of incarnations, then those who worship ancestors, deities and sages and finally those who worship petty forces (sun, wind) and spirits (water, wood, stone). This seems to be some kind of ranking of fullness of spiritual knowledge with the most satisfactory conception being that of the Absolute. He then points out that "It is, however, unfortunately the case that the majority of Hindus do not insist on this graduated scale but acquiesce in admittedly unsatisfactory conceptions of God." He sees this as the source of superstitious rites and customs, which I infer as having the ability to foment intercaste and interfaith violence. I am reminded of the example of untouchability which still exists in the subcontinent, or of Hindus who "purify" cigarettes
} 
crusade, inquisition or war for religious conversion completely alien to the Hindu. The toleration of Hinduism prevented conflict between the various sects (Roy, Ethics of Warfare 49). As Radhakrishnan says:

Hinduism developed an attitude of comprehensive charity instead of a fanatic faith in an inflexible creed. It accepted the multiplicity of aboriginal gods and others which originated, most of them, outside the Aryan tradition, and justified them all. It brought together into one whole all believers in God. Many sects professing many different beliefs live within the Hindu fold. Heresy-hunting, the favourite game of many religions, is singularly absent from Hinduism. (Indian Philosophy 21)

The universalism of Hinduism also brings with it a respect for the knowledge that other religions impart to their believers. Rather than merely inclusivist (holding that many diverse religions practices contain elements which can lead to the knowledge of the ultimate, and that religious practitioners will ultimately learn the truth through their religious convictions), Hinduism is universalist. It views no religion as incorrect for all are equally human efforts to obtain knowledge of the divine, which is transcendental and impersonal. Therefore, all religions are viewed as different paths to God. This promotes tolerance for the other, especially between people of different religious points of view.

The Gītā narrative is about a war, and if read literally, there might be an indication that violence may be necessary in some circumstances. However, in the Gītā, in only eight out of the seven hundred verses does Kṛ̣na directly encourage Arjuna to fight because it is his religious duty as a kșatriya. What Kṛṣna is really advocating is yoga. The final understanding that Arjuna gains is that he has to surrender to Kṛ̣na's will because his soul is a mere witness to the human drama, and what appears to be violence

given to them by Muslims by touching them on cow dung before smoking them. Those who conceive of the divine as the Absolute within them and in everyone else would most likely eliminate some of this intolerance which is sometimes, especially when exploited by political leader, can be expressed violently. 
is in fact nonviolence. ${ }^{138}$ As Roy says, "We must remember that the two epics [the Ramayana and the Mahābhārata] are not historical texts. They are a mixture of ballads, legends and myths along with some elements of historical memory" (Roy, Ethics of Warfare 18). The entire war of Kurukșetra really occurs in the field of dharma (dharmakșetre kurukșetre) (BG 1.1) and not in a physical place. The war imagery, however, is useful because it reflects that life itself is a constant struggle, and the warrior spirit is what we are supposed to be using to tackle the daily struggles of life.

Through the Gītā, Hinduism reflects a marked change from the Christian idea of a just cause in warfare. A "just interest" must form part of Western just war theory. A Hindu theory of war would be one without interest - one in which interest itself is destroyed. So Country A would not be able to invade Country B by claiming that it is because Country B is compromising Country A's interests. In many places, the Gìtā describes the ideal karma yogi as one who delights in the welfare of all beings or acting with the attitude of rejoicing in the welfare of all beings (BG 5.25, 6.4). A karma yogi is supposed to be free from all enmity. This kind of call to action, unlike the Christian just war theory, does not lend itself to the violence caused by the belief that under the gospel dispensation of grace, moral law is of no use because faith alone is necessary for salvation (Jackson 175). Only after negotiations proved fruitless did Arjuna fight, because of duty not for the expansion of territory, or to others, or for revenge or plunder, but with detachment in regard to personal loss or gain. This is why the Gītā has been used by so many as an instruction manual which challenges humans to act non-violently.

\footnotetext{
${ }^{138}$ At face value, this appears to be like the Christian just warrior's idea of fighting as an expression of love. However, the difference is that from a Vedāntic perspective, freeing an enemy soldier from his body (i.e. killing him) is improving his karma for the next life, and the enemy soldier too is never denied the ability to reach moksa; in Christianity, killing the enemy is seen as sending deserving souls to Hell and meting out the punishment of God.
} 


\section{Potential questions for empirical testing}

Some potential questions which could arise from studying the connection between warfare and models of epistemology are: Are religions with a hierarchical clergy more likely to yield fundamentalist intolerance of the other, and therefore, potentially cause more harm to non-coreligionists? Are religions which prioritise knowledge only as it agrees with faith more likely to be belligerent than worldviews which prioritise reason over blind faith?

\section{Conclusion}

The research indicates that some of the most important components of particular worldviews which may impact the way a particular group might think about warfare are its ontology, and its creation mythology, both of which are revealed through foundational (read: sacred) texts. Christian dogma creates ideas of anthropomorphism of God, a radical anthropocentric idea of the world, and a historicisation of mythology. The Bible may serve to glorify war in the stories of war in the Old Testament and may serve to perpetuate war by destroying the effectiveness of the scapegoat mechanism as well as by creating a violent image of God which causes fear amongst humans, and fear is one motivation for war. Monotheism and ideas of being a "chosen people" may contribute to the increase of artificial (or indeed, real) walls between various groups. A hatred of the Other is encouraged when a monopoly on the Truth is claimed by any religion. Hinduism seems to counteract many of these factors that contribute to the bellicose nature of 
Christianity. In Hinduism, anthropomorphising of God is reduced, and anthropocentrism is greatly diminished in the light of the theory of karma and reincarnation. Violence by external agents, including warfare, may be reduced through the impartial violence that is said to be meted out by karma, and karma also reduces empathy for victims. Finally, Hinduism's tolerance for a plurality of beliefs avoids demonising the Other perhaps increasing concord amongst various groups. However, when violence does occur, as with the nationalist movements and the rise of militant Hinduism after the nineteenth century, it is viewed as an anomaly, based, for eample, on interpretations of the Gītā that are literal and historic. As with Christianity, literal readings of scripture and historicisation of mythology seem to result in violence. And as with Christianity, when religious identities begin to blend and fuse into national identities, religiously motivated violence occurs.

Perhaps fortunately for those who consider themselves Christian, many of these criteria which form part of the Augustinian worldview do not exist today. Christians no longer claim that salvation is only for Christians. Forced conversions and Crusades are now condemned as ugly blemishes in the historic record of Christianity. Ideas of God tend to be less anthropomorphised, and even feminine conceptions of God are rising to the surface in some denominations. Anthropocentrism too is declining as Christians realise that the welfare of humanity is connected to the welfare of the earth and all the creatures and resources that it offers. One cannot deny that perhaps many of these changes were the result of Christianity essentially being defanged after the Enlightenment. Therefore, the loss of power in the Church provided an impetus for nonviolent solutions. Some would argue that Gandhi's fixation with non-violence (instead of 
dharmayuddha) was also the result of the loss of power of the Hindus in India, first to the Moghuls, and then to the British.

However, regardless of changes in religious viewpoints, politically, the myth of the just war continues to be a part of international discourse. The basic framework of Augustine's just war doctrine continues to permeate our post-Enlightenment world in international initiatives like $R 2 P$. The impact of this is wide reaching. How countries adhere to just war criteria form the basis of military alliances; those who are seen as violating the principles are cast as the axis of evil. Just war can even impact a country's immigration and refugee policy if rights of conscientious objection are not recognised. Perhaps more research in the area of International Political Theology will expose how many elements of our current thinking about war are based on Christian metaphysical assumptions that are no longer relevant. In changing our ideas about war through discourse with people who have different assumptions, it may be feasible to change our current rules of war so that they will truly be universal aspirations.

Metaphysical assumptions, whether derived from religion or not, do impact our lives and how we make decisions: they influence how we think of ourselves and our relationship with God (if we are theists); they affect our relationship with other humans, non-humans and our planet in general; they control what we think of as good or bad and how we characterise crimes; they influence how we vote, whom we allow to vote; whom we marry, whom we allow others to marry; what we eat and how we eat, what we wear and what we allow others to wear; how we raise our children; and of course, how and why we support wars. I believe that this research shows a promising way in which International Political Theology can move forward. It serves as a framework for 
understanding religiously motivated violence. Perhaps part of the solution to the problem of violence is to understand all the factors that motivate it, not just those which readily appear on the surface. Only with that kind of understanding does the true justice or injustice of war reveal itself more clearly. 


\section{Works Cited}

(Note: All websites were last accessed on July 1, 2013)

74th General Convention. Cross Before Flag. Chicago: Episcopal Peace Fellowship, 2005.

181st General Assembly (1969), 694, in Presbyterian Church (U.S.A.). A Composite Review of General Assembly Statements on Peacemaking and the Arms Race. New York: Office of the General Assembly [PCUSA], 1984.

Apostel, Leo. "What is a Worldview?" Eds. Van Belle, H. \& Van der Veken, J., Nieuwheid denken. De wetenschappen en het creatieve aspect van de werkelijkheid $<\mathrm{http}$ ///cogprints.org/6094/2/Vidal_2008-what-is-aworldview.pdf $>$.

Appadorai, A. Indian Political Thinking Through the Ages. New Delhi: Khama Publishers, 1992.

Aquinas, Thomas. Summa Theologice, Beniger Bros. edition, 1947 $<$ http://ethics.sandiego.edu/Books/Texts/Aquinas/JustWar.html $>$.

Armstrong, Karen. Holy War. New York: Anchor Books, 2001.

Augustine. City of God. Trans. Henry Bettenson. 1972. London: Penguin Books Ltd., 1984

--- De peccatorum meritis.

$<\mathrm{http}: / /$ www.documentacatholicaomnia.eu/03d/0354-

0430,_Augustinus,_De_Peccatorum_Meritis_Et_Remissione_Et_De_Baptis mo_Parvulorum_\%5BSchaff\%5D,_EN.pdf $>$.

--- "The Literal Meaning of Genesis." Ancient Christian Writers. vol. 41. Trans. and ed. John Hammond Taylor, S.J. New York: Paulist Press, 1982.

Avalos, Hector. "Violence in the Bible and the Bhagavad-gittă." Holy War: Violence and the Bhagavad Gita. Ed. Steven J. Rosen. Hampton, VA: Deepak Heritage Books, 2002.

Avari, Burjor. India, The Ancient Past: A History of the Indian Subcontinent from $c$. 7000 BC to AD 1200. New York: Routledge, 2007.

Bachrach, David Steward. Religion and the Conduct of War: C.300-1215. Woodbridge: Boydell Press, 2003. 
Bailie, Gil. Violence Unveiled - Humanity at the Crossroads. New York: The Crossroad Publishing Company, 1995.

Balling, Jakob. The Story of Christianity: From Birth to Global Presence.

Michigan/Cambridge: William B. Eerdmans Publishing Company, 2003.

Barua, Pradeep B. State at War in South Asia. Lincoln and London, NE: University of Nebraska Press, 2005.

Basham, A.L. Ed. A Cultural History of India, Oxford: Oxford University Press, 1975.

Bass, Gary J. "Jus Post Bellum.” Philosophy and Public Affairs 32, no. 3 (October 2004): $384-412$.

Bauerschmidt, Frederick Christian. “Aquinas.” The Blackwell Companion to Political Theology, Eds. Peter Scott and William T. Cavanaugh, Malden, MA: Blackwell Publishing Ltd., 2007. 48-61.

Beier, Matthias. A Violent God-Image: An Introduction to the Work of Eugen Drewermann. New York \& London: The Continuum International Publishing Group Inc., 2004.

Bernstein, Andrew. Debate: Christianity: Good or Bad for Mankind? (Dinesh D’Souza v. Andrew Bernstein) University of Texas, Austin, February 8, 2013

$<$ http://www.youtube.com/watch?v=Gy5OajO7nrc $>$.

The Blackwell Companion to the Bible and Culture. Ed. John F.A. Sawyer, West Sussex, UK: Blackwell Publishing Ltd., 2012.

The Bhagavadgita. Trans. S. Radhakrishnan. Delhi: HarperCollins Publishers India, 1994.

The Bhagavad Gita, Trans. Winthrop Sargeant. Albany, NY: State University of New York Press, 1984.

Bhagavad-Gītā As It Is. Trans. Swami A. C. Bhaktivedanta Prabhupāda. Los Angeles, CA: The Bhaktivedanta Book Trust, 1968.

The Blackwell Companion to Political Theology. Eds. Peter Scott and William T.

Cavanaugh. Oxford: Blackwell Publishing Ltd., 2004.

"Brahmastra" <http://en.wikipedia.org/wiki/Brahmastra>

Brekke, Torkel. "The Ethics of War and the Concept of War in India and Europe." NUMEN, vol. 52 (2005). 
Carter, Stephen L. God's Name in Vain: The Wrongs and Rights of Religion in Politics. New York: Basic Books, 2000.

Catechism of the Catholic Church.

$<$ http://www.scborromeo.org/ccc/p3s2c2a5.htm\#2309>.

Cavanaugh, William T. Migrations of the Holy: God, State, and the Political Meaning of the Church. Grand Rapids, MI: Wm. B. Eerdmans Publishing Company, 2011.

"The Challenge of Peace." The US Catholic Bishops Peace Pastoral. Washington, D.C., May, 1983.

Chapple, Christopher K. "Ahimsā in the Mahābhārata." Holy War: Violence and the Bhagavad Gita, Ed. Steven J. Rosen. Hampton, VA: Deepak Heritage Books, 2002. 145-162.

Charles, J. Daryl. Between Pacifism and Jihad: Just War and Christian Tradition. Downers Grove, IL: Inter VarsityPress, 2005.

Chatterjee, R.K. The Gita and its Culture. New Delhi: Sterling Publishers Private Limited, 1987.

Childs, James M. Jr. "Nuclear Policy and the Ethics of Anticipation." Peace and the Just War Tradition, Ed. Michael J. Stelmachowicz. New York: Lutheran Council in the USA, 1986.

Chinnick, Julia. "Hinduism and Mimetic Theory: A Response." Contagion, Volume 9, Spring 2002. 140-150.

“Christian Conscience and Modern Warfare," La Civiltà Cattolica, Rome, Italy, July 6, 1991.

"Christianity and the ethics of war"

$<$ http://www.bbc.co.uk/religion/religions/christianity/christianethics/war.sht $\mathrm{ml}>$.

Claude, Inis L. Jr. “Just Wars: Doctrines and Institutions.” Political Science Quarterly, Vol. 95, No. 1. (Spring, 1980). 83-96.

Clooney, Francis X. (SJ). "Violence and Nonviolence in Hindu Religious Traditions." Contagion, Volume 9, Spring 2002. 109-139.

Clough, Bradley S. "Gandhi, Non-violence and the Bhagavad-gita." Holy War: Violence and the Bhagavad Gita, Ed. Steven J. Rosen. Hampton, VA: Deepak Heritage Books, 2002. 59-80. 
Clough, David L. and Brian Stiltner. Faith and Force: A Christian Debate About War. Washington D.C.: Georgetown University Press, 2007.

Cohen, Stephen P. India: Emerging Power. 2001, New Delhi: Oxford University Press, 2003.

Cohn-Sherbok, Dan. "War and Peace in Judaism." War and Peace in World Religions. Ed. Perry Schmidt-Leukel, London: SCM Press, London, 2004. 81-98.

Dharmānanda, Swami. Advance [sic] Yoga Study: The Science of Yoga, Ayurveda, Tantra, Vedanta Indian Spirituality, Phylosophy [sic], Religious and Social Traditions. $<\mathrm{http} / /$ www.healthandyoga.com/html/readingroom/ays/ays177.asp $>$.

Dirks, Nicholas B. Castes of Mind: Colonialism and the Making of Modern India, Princeton, NJ: Princeton University Press, 2001.

Dodd, Vikram, Shiv Malik and Ben Quinn. "Woolwich killing: meat cleaver, knife and jihadist claims filmed on mobile," The Guardian, Wednesday 22 May 2013. $<$ http://www.theguardian.com/uk/2013/may/22/woolwich-attack-cleaverknife-jihadist>.

Doniger, Wendy. The Hindus. New York: Penguin Press, 2009.

Dougherty, James E. The Bishops and Nuclear Weapons. Hamden: Archon Book, 1984.

Ehrman, Bart D. Misquoting Jesus: The Story Behind Who Changed the Bible and Why. New York, NY: HarperCollins Publishers, 2005.

Eliade, Mircea. Yoga: Immortality and Freedom. Trans. Willard R. Trask. Pantheon Books: New York, 1958.

Elshtain, Jean Bethke. "Augustine." The Blackwell Companion to Political Theology, Eds. Peter Scott and William T. Cavanaugh, Malden, MA: Blackwell Publishing Ltd., 2007. 35-47.

Ember, C. R. and M. Ember. "Resource unpredictability, mistrust, and war: A cross cultural study." Journal of Conflict Resolution 36 (1982), 242-262.

Episcopal Diocese of Washington. The Nuclear Dilemma, Cincinnati: Forward Movement Publications, 1987.

Fiala, Andrew. The Just War Myth. Plymouth, UK: Rowman \& Littlefield Publishers Inc., 2008. 
Firmage, Edwin Brown. "Violence and the Gospel: The Teachings of the Old Testament, the New Testament, and the Book of Mormon," BYU Studies 25 (1985): 48.

"Five Principles." Encyclopcedia Britannica (2013)

$<$ http://www.britannica.com/EBchecked/topic/1420835/Five-Principles>.

Flood, Gavin. An Introduction to Hinduism. Cambridge: Cambridge University Press, 1996.

Freeman, Charles. The Closing of the Western Mind: The Rise of Faith and the Fall of Reason. New York, NY: Vintage Books, 2002.

Forster, E.M. Passage to India. Harvest Books, 1965.

"The Four Margas or Paths of Yoga," Advaita Yoga Ashrama. $<$ http://yoga108.org/pages/show/7>.

Gandhi, M. K. Selected Letters, "Letter to Adolf Hitler, July 23, 1939 $<$ http://www.mkgandhi.org/letters/hitler_ltr1.htm>.

Geertz, Clifford. The Interpretation of Cultures. New York, NY: Basic Books, 1973.

Geneva Conventions.

$<$ http://usmilitary.about.com/od/deploymentsconflicts/l/blgenevaconv.htm>.

Ghoshal, U. A History of Hindu Political Theories, London: Oxford University Press, 1923.

Gier, Nicholas F. Religiously Motivated Violence in Asia: India, Sri Lanka, Tibet, China and Japan, (A book prospectus).

$<$ http://www.webpages.uidaho.edu/ngier/orvproposal.htm>.

Girard, René. Deceit, Desire, and the Novel. Baltimore: Johns Hopkins University Press, 1965.

--- The Girard Reader. New York: Crossroad Pub Co, 1996.

--- "Mimesis and Violence: Perspectives in Cultural Criticism." Berkshire Review 14 (1979): 9-19.

--- The Scapegoat. Baltimore: Johns Hopkins University Press, 1986.

--- "Violence, Difference, Sacrifice: A Conversation with Rene Girard," Religion and Literature 25 (1993): 9-33.

Glanville, Luke. "Christianity and the Responsibility to Protect." Studies in Christian Ethics 25(3) 312-326, 2012. 
Godman, David, Ed. The Teachings of Sri Ramana Maharshi. London: Arkana, 1985.

Gomes, Keith J. "An Intellectual Genealogy of the Just War: A Survey of Christian Political Thought on the Justification of Warfare." Small Wars Journal, August 3, $2008<\mathrm{http}: / /$ smallwarsjournal.com/mag/2008/08/an-intellectualgenealogy-of-t.php $>$.

Gopal S. and U. Iyengar, Eds. The Essential Writings of Jawaharlal Nehru. 2 vols. New Delhi: Oxford University Press, 2003.

Grant, Michael. The Fall of the Roman Empire.1976. London: Phoenix, 2005.

Halsell, Grace. Prophecy and Politics: The Secret Alliance between Israel and the U.S. Christian Right. Chicago: Lawrence Hill and Co., 1989.

Hazlett, Ian. "War and Peace in Christianity." War and Peace in World Religions. Ed. Perry Schmidt-Leukel, London: SCM Press, 2004. 99-147.

Heathcote, T.A. The Military in British India: The Development of British Land Forces in South Asia, 1600-1947. Manchester: Manchester University Press, 1995.

Henry, Matthew. Commentary on the Whole Bible, 1706

$<\mathrm{http}: / /$ www.biblestudytools.com/commentaries/matthew-henry-complete>.

Hick, John H. The Philosophy of Religion. 3d ed. Englewood Cliffs, N.J.: Prentice Hall, 1983.

Hiriyanna, M. Outlines of Indian Philosophy. London: George Allen \& Unwin, 1964.

Holmes, Arthur F., Ed. War and Christian Ethics: Classical and Contemporary Readings on the Morality of War. $2^{\text {nd }}$ ed. Grand Rapids, MI: Baker Academic, 2005.

Holmes, Robert L. "Can War Be Morally Justified? Just War Theory. Ed. Jean Bethke Elshtain. New York, NY: New York University Press, 1992. 197-233.

Hooper, Walter, Ed. The Weight of Glory and Other Addresses, rev. ed. New York: Macmillan, 1965.

Hume, Robert E. "Hinduism and War", The American Journal of Theology, Vol. 20, No. 1, (Jan., 1916), 31-44.

Husserl, E. The Crisis of European Sciences and Transcendental Phenomenology, Ed. and trans. David Carr, Evanston: Northwestern University Press, 1970. 
Huxley, Aldous. "The Minimum Working Hypothesis." Vedanta for the Western World. Ed. Christopher Isherwood. London: Compton Printing Works, 1948. 3335.

Isherwood, Christopher. Ed. Vedanta for the Western World. London: Compton Printing Works, 1948.

--- "The Gita and War," Vedanta for the Western World. Ed. Christopher Isherwood. London: Compton Printing Works, 1948. 354-357.

Iyer, Raghavan, Ed. The Essential Writings of Mahatma Gandhi. 1993. New Delhi: Oxford University Press, 2007.

Jackson, William. "The Use and Abuse of Holy War Imagery." Holy War: Violence and the Bhagavad Gita. Ed. Steven J. Rosen. Hampton, VA: Deepak Heritage Books, 2002. 163-202.

John Paul II (Pope). General Audience 31 May 1995.

$<$ http://www.vatican.va/holy_father/john_paul_ii/audiences/alpha/data/aud19 950531en.html>.

Johnson, James Turner. Just War Tradition and the Restraint of War: A Moral and Historical Inquiry. Princeton, NJ: Princeton University Press, 1981.

Johnson, John F. “Can War Be Just?” Lutheran Witness 122, no. 1 (January 2003).

Jones, Constance A. and James D. Ryan. Hinduism. New York, NY: Infobase Publishing, 2007.

"Just War Doctrine" < http://www.catholic.com/documents/just-war-doctrine>.

Kapila, Shruti. “A History of Violence,” Modern Intellectual History, 7,2 (2010), 437457.

Kautilya. The Arthashastra. Ed. and trans. L.M. Rangarajan. 1987. New Delhi: Penguin Books, 1992.

Kelsay, John and Johnson, James Turner, Eds., Just War and Jihad. Westport, CT: Greenwood Press, 1991.

Kena Upanișad $<$ http://www.bharatadesam.com/spiritual/upanishads/kena_upanishad.php>.

Klostermaier, Klaus K. A Survey of Hinduism. $2^{\text {nd }}$ ed. New York, NY: State University of New York Press, 1994. 
Kubálková, Vendulka. "Religion in the International Relations Classroom.” Presented at a panel Religions Facing Globalization (Theme RC43) Religion and Politics, Tuesday, July 11, $2006<$ http://paperroom.ipsa.org/papers/paper_5432.pdf>.

Kumar, Frederick L. The Philosophies of India - A New Approach. Studies in Asian Thought and Religion Volume 14. New York: The Edwin Mellen Press, 1991.

Kung, Hans. "Religion, Violence and "Holy Wars"." International Review of the Red Cross, vol. 87, no. 858 (2005).

Kuruvachira, J. "Bal Gangadhar Tilak's Rationalisation of Violence through the Interpretation of the Gita" $<$ http://www.google.ca/url?sa=t\&rct=j\&q=\&esrc $=$ s\&source=web\&cd $=1 \& v e$ $\mathrm{d}=0 \mathrm{CCkQFjAA} \& u r l=\mathrm{http} \% 3 \mathrm{~A} \% 2 \mathrm{~F} \% 2 \mathrm{Fdonboscoindia} . \operatorname{com} \% 2 \mathrm{Fenglish} \% 2 \mathrm{Fr}$ esourcedownload.php\%3Fpno\%3D1\%26secid\%3D246\&ei=dxeJUsX1OcHK 2gXDpID4AQ\&usg=AFQjCNGIH5kHDyIvIeC1ZCpVebn9TUqig\&cad=rja $>$.

Lal, Vinay. "Hinduism." Encylcopedia of the Modern World. Ed. Peter N. Stearns, New York \& Oxford: Oxford University Press, 2008. Vol IV, 10-16.

Land, Richard D. "The Crisis in the Persian Gulf and 'Just Wars'." Light (April-June 1991): 2 .

Lewis, C.S. "Why I Am Not a Pacifist." The Weight of Glory and Other Addresses. Ed. Walter Hooper. rev. ed., New York, NY: Macmillan, 1965.

Lindberg, Tod. The Political Teachings of Jesus. New York, NY: HarperCollins Publishers, 2007.

Luther, Martin. "Secular Authority: To What Extent It Should be Obeyed." $<$ http://www.isom.vnsalvation.com/Resources\%20English/Christian\%20Ebo oks/Martin\%20Luther\%20On\%20Secular\%20Authority.pdf>.

Mahābhārata. Trans. William Buck. New Delhi: Motilal Banarsidass, 2000.

Mann, William E. "Augustine on evil and original sin." The Cambridge Companion to Augustine, Eds. Eleonore Stump and Norman Kretzmann, Cambridge UK: Cambridge University Press, 2001. 40-48.

Marshall, Taylor. "Good Friday Prayer for the Jews - A Controversial History and Theology." April 6, 2012. <http:/www.taylormarshall.com/2012/04/goodfriday-prayer-for-jews.html>. 
Martin, Reginald (O.P.). "Theology of the Laity: Gifts of the Holy Spirit, Part II - The Fear of the Lord." The Rosary Light \& Life, Vol. 64, No 6, Nov-Dec 2011. $<$ http://www.rosary-center.org/1164n6.htm>.

Mattox, John Mark. Saint Augustine and the Theory of Just War. London: Continuum, 2005.

McGrath, Alister E. Christian Theology. $2^{\text {nd }}$ ed. Malden, MA: Blackwell Publishers Inc., 1997.

Miller, Richard B. Interpretations of Conflict: Ethics, Pacifism, and the Just-War Tradition. Chicago: University of Chicago Press, 1991.

Mohanraj, V.M. The Warrior and the Charioteer: A Materialist Interpretation of the Bhagavad Gita. New Delhi: Left Word, 2005.

Mohanty, Jitendra Nath. Reason and Tradition in Indian Thought: An Essay on the Nature of Indian Philosophical Thinking. Oxford: Clarendon Press, 1992.

National Conference of Catholic Bishops. The Challenge of Peace. Washington, DC: United States Catholic Conference, 1983.

Nelson-Pallmeyer, Jack. Is Religion Killing Us? Violence in the Bible and the Quran. Harrisburg, PA: Trinity Press International, 2003.

Onuf, Nicholas. World of Our Making. Columbia, SC: University of South Carolina Press, 1989.

Orend, Brian. “Jus Post Bellum.” Journal of Social Philosophy 31, no. 1 (Spring 2000): 117-37.

Organ, Troy Wilson. The Hindu Quest for the Perfection of Man. Athens: Ohio University, 1970.

"Pāśupatāstra." < http://en.wikipedia.org/wiki/Pashupatastra>.

Pervez, Muhammad Shoaib. Security Community in South Asia: India-Pakistan. Oxon: Routledge, 2013.

Petito, Fabio and Pavlos Hatzopoulos, Eds. Religion in International Relations: The Return from Exile. New York, NY: Palgrave Macmillan, 2003.

Picard, Max. The World of Silence. Washington, D.C.: Regnery Gateway, 1988.

Power, Samantha. "Humanitarian Intervention: A Forum.” Nation, July 14, 2003 $<$ www.globalpolicy.org/empire/humanint/2003/0714nation.htm>. 
Prabhavananda, Swami. "What Yoga Is." Vedanta for the Western World. Ed. Christopher Isherwood. London: Compton Printing Works, 1948. 41-46.

Presbyterian Church in America. "Christian Responsibility in a Nuclear Age." $<$ www.pcahistory.org/pca/1-439.html>.

Radhakrishnan, S. Indian Philisophy, Volume 2, Delhi: Oxford University Press, 1923. ---The Hindu View of Life. 1927. Noida, India: HarperCollins Publishers, 2012.

Rambachan, Anantanand. The Advaita Worldview: God, World, and Humanity. Albany, NY: State University of New York Press, 2006.

Ram-Prasad, C. "Contemporary Political Hinduism." The Blackwell Companion to Hinduism, Ed. Gavin Flood, New Delhi: Wiley India Pvt. Ltd., 2003. 526550.

Ramsey, Paul. Basic Christian Ethics. 1950. Louisville, KY: Westminster/John Knox Press, 1993.

Ranganathan, Shyam. "Hindu Philosophy." The Internet Encyclopedia of Philosophy. $<$ http://www.iep.utm.edu/h/hindu-ph.htm\#SH3f $>$.

Ravitzky, Aviezer. "Prohibited Wars in the Jewish Tradition." The Ethics of War and Peace: Religious and Secular Perspectives, Ed. Terry Nardin. Princeton, NJ: Princeton University Press, 1996. 115-127.

The Responsibility to Protect. Report of the International Commission on Intervention and State Sovereignty. Ottawa: International Development Research Centre, 2001.

The Responsibility to Protect. Research, Bibliography, Background, Supplementary Volume to the Report of the International Commission on Intervention and State Sovereignty. Ottawa: International Development Research Centre, 2001.

Ridley, Ronald T. "The Hoplite as Citizen: Athenian Military Institutions in their Social Context.” Antiquité Classique, 48, 1979, 508-48.

Robert, Paul W. "Mahābharata - Myth or Truth: A Critical Analysis." $<$ http://www.youtube.com/watch?v=nPDiVVdtdv8 $>$.

Roosevelt. Franklin D. Fireside Chat. December 9, 1941. $<$ http://www.presidency.ucsb.edu/ws/?pid=16056\#axzz2hp40yotX $>$. 
Rosemont, Henry Jr. and Huston Smith. Is there a Universal Grammar of Religion? Peru, Illinois: Carus Publishing Company, 2008.

Rosen, Steven J., Ed. Holy War: Violence and the Bhagavad Gita. Hampton, VA: Deepak Heritage Books, 2002.

Ross, Marc H. "Internal and external conflict and violence: Cross cultural evidence and a new analysis." Journal of Conflict Resolution 29 (1985), 547-579.

Rowland, Christopher. "Scripture: New Testament." The Blackwell Companion to Political Theology, Eds. Peter Scott and William T. Cavanaugh. Oxford: Blackwell Publishing Ltd., 2004. 21-34.

Roy, Kaushik. Ethics of Warfare in South Asia: From Antiquity to the Present. New Delhi: Cambridge University Press, 2012.

--- "Just and Unjust War in Hindu Philosophy." Journal of Military Ethics, 6:3, 232-245 (2007).

Russell, Frederick H. The Just War in the Middle Ages, Cambridge University Press, 1975.

--- "Only Something Good Can Be Evil: The Genesis of Augustine's Secular Ambivalence.” Theological Studies 51 (1990): 698-716.

Russell, Jeffrey Burton. Satan: The Early Christian Tradition. Ithaca, NY: Cornell University Press, 1981.

Sastri Yagnapurushadji and Others v. Muldas Brudardas Vaishya and Another. 1966 SCR (3) 242. <http://judis.nic.in>.

Scheer, Robert. "With God on His Side... By Invoking a Higher Power, Bush Sidesteps Pesky Constitutional Issues." Los Angeles Times, Tuesday, April 20, 2004 $<$ www.commondreams.org/views04/0420-01.htm>.

Schwartz, Regina M. The Curse of Cain: The Violent Legacy of Monotheism. Chicago: University Press, 1997.

Sharma, Arvind. Modern Hindu Thought: An Introduction. New Delhi: Oxford University Press, 2005.

--- The Philosophy of Religion and Advaita Vedānta: A Comparative Study in Religion and Reason. University Park, PA: The Pennsylvania State University Press, 1995.

Shinnick, Julia W. "Hinduism and Mimetic Theory: A Response." Contagion, Volume 9, Spring 2002. 140-150. 
Singh, R.C.P. Kingship in Northern India. Delhi: Shree Jainendra Press, 1968.

Smith, Huston. The Soul of Christianity: Restoring the Great Tradition. New York, NY: Harper Collins, 2005.

Spellman, John W. Political Theory of Ancient India: A Study of Kingship from the Earliest Times to circa A.D. 300. Oxford: Clarendon Press, 1964.

Spong, John Shelby "The Judeo-Christian Faith Story: How Much is History?" Lecture at Chautauqua Institution, June 2012.

$<$ http://www.youtube.com/watch?v=JrNJR2bZNdA $>$.

--- Living in Sin? A Bishop Rethinks Human Sexuality. New York, NY: HarperCollins, 1990.

--- "Re-Casting the Christ Story: Not a Rescue Operation, but the Birth of a New Consciousness." Lecture at Chautauqua Institution, 29 June 2012. $<\mathrm{http}: / /$ www.youtube.com/watch?v=WDNz2Ifn9k4>.

--- The Sins of Scripture: Exposing the Bible's Tests of Hate to Reveal the God of Love. New York, NY: HarperCollins, 2005.

Stagg, Evelyn and Frank Stagg. Woman in the World of Jesus. Philadelphia: Westminster Press, 1978.

Stead, Christopher. Philosophy in Christian Antiquity. Cambridge: Cambridge University Press, 1994.

The Story of India, Episode 4 - Ages of Gold - BBC Documentary. $<$ http://www.youtube.com/watch?v=Emp_lxFuGG8>.

Strousma, Guy. Barbarian Philosophy: The Religious Revolution of Early Christianity. Tubingen, 1999.

Stump, Eleonore and Norman Kretzmann, Eds. The Cambridge Companion to Augustine. Cambridge UK: Cambridge University Press, 2001.

Subedi, Surya P. "The Concept in Hinduism of 'Just War'." Journal of Conflict and Security Law (2003), Vol. 8 No. 2, 339-361.

Thapar, Romila. The Mauryas Revisited. 1987. Calcutta: K.P. Bagchi \& Company, 1993.

Thomas, Scott M. The Global Resurgence of Religion and the Transformation of International Relations - The Struggle for the Soul of the Twenty-First Century. New York, NY: Palgrave Macmillan, 2005. 
Thornton, Rod. "The British Army and the Origins of Its Minimum Force Philosophy." Small Wars \& Insurgencies, vol. 15, no. 1 (2004), 83-106.

Tripurari, Swami B.V. "Bhagavad-gìtā: Seeing Nonviolence in the Violent Play of God.” Holy War: Violence and the Bhagavad Gita. Ed. Steven J. Rosen. Hampton,VA: Deepak Heritage Books, 2002.

Trivedi, Mark. Mohandas Gandhi: The Man and His Vision, Calcutta, India: Time Publications, 1968.

United Methodist Council of Bishops. In Defense of Creation. Nashville: Graded Press, 1986.

United Press International. "World terrorism will rise, expert says.” March. 23, 2011. $<$ http://www.upi.com/Top_News/World-News/2011/03/23/World-terrorismwill-rise-expert-says/UPI-33051300891489/>.

Van Geest, Paul. "Augustine's Evaluation of Fear."

$<$ http://www.tilburguniversity.edu/research/theology/programmes/identity/in dividual/geest/\#top>.

Vitoria, Franciso de. "On the Morality of War." The Morality of War: Classical and Contemporary Readings. Eds. Larry May, Eric Rovie and Steve Viner, Toronto: Pearson, 2005.

Vivekānanda, Swami. "The Ideal of Karma-Yoga." $<$ http://www.jnanajyoti.com/article/article.php?id=65>.

Von Brück, Michael. "War and Peace in Hinduism." War and Peace in World Religions. Ed. Perry Schmidt-Leukel. London: SCM Press, 2004.

Wallace, Mark I. and Theophus H. Smith, Eds. Curing Violence. Sonoma: Polebridge Press, 1994.

Walter, Tony and Helen Waterhouse. "A Very Private Belief: Reincarnation in Contemporary England.” Sociology of Religion (1999) 60 (2): 187-197.

Walzer, Michael. Just and Unjust Wars. New York: Basic Books, 1977.

--- "War and Peace in the Jewish Tradition." The Ethics of War and Peace: Religious and Secular Perspectives, Ed. Terry Nardin. Princeton, NJ: Princeton University Press, 1996. 95-114. 
Weber, A. "Feminist Peace and Conflict Theory." Routledge Encyclopedia on Peace and Conflict Theory, 2006, 2-13.

$<$ http://www.uibk.ac.at/peacestudies/downloads/peacelibrary/feministpeace.p df $>$.

Webster, Alexander F.C. and Darrell Cole. The Virtue of War: Reclaiming the Classic Christian Traditions East and West. Salisbury MA: Regina Orthodox Press Inc., 2004.

Wells, Donald A. The War Myth. New York: Pegasus. 1967.

Wilkins, Brett. "The Christianization of the US Military in the War on Terror." Moral Low Ground, January 9, 2011. <http://morallowground.com/2011/01/09/thechristianization-of-the-us-military-in-the-war-on-terror/>.

Winright, Tobias. "Never Again: The Responsibility to Protect as an Emerging Ethical Norm." The Cresset, Trinity 2012, Vol. LXXV, No. 5, 30-34.

$<$ http://thecresset.org/2012/Trinity/Winright_T2012.html>.

Wright, Robert. The Evolution of God, Little, New York: Brown and Company, 2009.

Yagnapurushadji and Others v. Vaishya and Another, 1966 SCR (3) 242 $<\mathrm{http}: / /$ judis.nic.in>.

Yogānanda, Paramhansa. The Essence of the Bhagavad Gìta explained by Paramhansa Yogananda as remembered by his disciple, Swami Kriyananda. Nevada City, CA: Crystal Clarity Publisher, 2006.

Younger, Paul. Introduction to Indian Religious Thought. Darton, Longman \& Todd Ltd, 1972.

Zaehner, R.C. Hinduism. Oxford: Oxford University Press, 1962.

Zampaglione, Geraldo. The Idea of Peace in Antiquity. Trans. Richard Dunn. Notre Dame, IN: University of Notre Dame Press, 1973. 


\section{APPENDIX}

Synoptic table comparing just war frameworks found in Aquinas' Summa Theologiæ, the Catechism of the Catholic Church and Responsibility to Protect (R2P)

\begin{tabular}{|c|c|c|c|}
\hline $\begin{array}{c}\text { Augustine's } \\
\text { jus ad } \\
\text { bellum } \\
\text { Criteria }\end{array}$ & Aquinas & Catechism of the Catholic Church & Responsibility to Protect \\
\hline $\begin{array}{l}\text { Overall } \\
\text { justification } \\
\text { for war }\end{array}$ & $\begin{array}{l}\text { Justifications (religious): } \\
\text { And just as it is lawful for them to have } \\
\text { recourse to the sword in defending that } \\
\text { common weal against internal disturbances, } \\
\text { when they punish evil-doers, according to the } \\
\text { words of the Apostle (Rm. 13:4): "He } \\
\text { beareth not the sword in vain: for he is God's } \\
\text { minister, an avenger to execute wrath upon } \\
\text { him that doth evil"; so too, it is their business } \\
\text { to have recourse to the sword of war in } \\
\text { defending the common weal against external } \\
\text { enemies. Hence it is said to those who are in } \\
\text { authority (Ps. 81:4): "Rescue the poor: and } \\
\text { deliver the needy out of the hand of the } \\
\text { sinner"; and for this reason Augustine says } \\
\text { (Contra Faust. xxii, 75): "The natural order } \\
\text { conducive to peace among mortals demands } \\
\text { that the power to declare and counsel war } \\
\text { should be in the hands of those who hold the } \\
\text { supreme authority." }\end{array}$ & $\begin{array}{l}\text { Justifications (religious): } \\
\text { Insofar as men are sinners, the threat of war } \\
\text { hangs over them and will so continue until } \\
\text { Christ comes again; but insofar as they can } \\
\text { vanquish sin by coming together in charity, } \\
\text { violence itself will be vanquished and these } \\
\text { words will be fulfilled: "they shall beat their } \\
\text { swords into plowshares, and their spears into } \\
\text { pruning hooks; nation shall not lift up sword } \\
\text { against nation, neither shall they learn war } \\
\text { any more." }\end{array}$ & $\begin{array}{l}\text { Justification (historic): } \\
R 2 P \text { Research indicates that especially } \\
\text { amongst the trans-Atlantic community, } \\
\text { humanitarian intervention (even in the } \\
\text { absence of Security Council authorisation, in } \\
\text { some cases) has been recognised as } \\
\text { legitimate as a matter of practice. It cites a } \\
\text { precedent for humanitarian intervention that } \\
\text { goes back to the } 1827 \text { intervention in Greece } \\
\text { by England, France and Russia ( } 2 P \\
\text { Research } 23,16 \text { ). Connections to Christian- } \\
\text { influenced international law and R2P have } \\
\text { been made by many writers. Note that even } \\
R 2 P \text { Research indicates that amongst } \\
\text { developing countries (read: traditionally non- } \\
\text { Christian countries), the predominant view is } \\
\text { a scepticism towards humanitarian } \\
\text { intervention as merely another rationalisation } \\
\text { for unwanted interference by norm-enforcing } \\
\text { developed countries ( } R 2 P \text { Research } 23 \text { ). }\end{array}$ \\
\hline $\begin{array}{l}\text { Declaration } \\
\text { of War by a } \\
\text { Competent }\end{array}$ & $\begin{array}{l}\text { First, the authority of the sovereign by whose } \\
\text { command the war is to be waged. For it is } \\
\text { not the business of a private individual to } \\
\text { declare war, because he can seek for redress }\end{array}$ & $\begin{array}{l}\mathbf{2 3 0 8} \text { All citizens and all governments are } \\
\text { obliged to work for the avoidance of war. } \\
\text { However, "as long as the danger of war } \\
\text { persists and there is no international authority }\end{array}$ & $\begin{array}{l}\text { Right Authority } \\
\text { A. There is no better or more appropriate } \\
\text { body than the United Nations Security } \\
\text { Council to authorize military intervention for }\end{array}$ \\
\hline
\end{tabular}




\begin{tabular}{|c|c|c|c|}
\hline Authority & $\begin{array}{l}\text { of his rights from the tribunal of his superior. } \\
\text { Moreover it is not the business of a private } \\
\text { individual to summon together the people, } \\
\text { which has to be done in wartime. }\end{array}$ & $\begin{array}{l}\text { with the necessary competence and power, } \\
\text { governments cannot be denied the right of } \\
\text { lawful self-defence, once all peace efforts } \\
\text { have failed." } \\
\mathbf{2 3 1 0} \text { Public authorities, in this case, have the } \\
\text { right and duty to impose on citizens the } \\
\text { obligations necessary for national defence. } \\
\text { Those who are sworn to serve their country } \\
\text { in the armed forces are servants of the } \\
\text { security and freedom of nations. If they carry } \\
\text { out their duty honourably, they truly } \\
\text { contribute to the common good of the nation } \\
\text { and the maintenance of peace. } \\
\text { 2311 Public authorities should make } \\
\text { equitable provision for those who for reasons } \\
\text { of conscience refuse to bear arms; these are } \\
\text { nonetheless obliged to serve the human } \\
\text { community in some other way. }\end{array}$ & $\begin{array}{l}\text { human protection purposes. The task is not to } \\
\text { find alternatives to the Security Council as a } \\
\text { source of authority, but to make the Security } \\
\text { Council work better than it has. } \\
\text { B. Security Council authorization should in } \\
\text { all cases be sought prior to any military } \\
\text { intervention action being carried out. Those } \\
\text { calling for an intervention should formally } \\
\text { request such authorization, or have the } \\
\text { Council raise the matter on its own initiative, } \\
\text { or have the Secretary-General raise it under } \\
\text { Article } 99 \text { of the UN Charter. } \\
\text { C. The Security Council should deal } \\
\text { promptly with any request for authority to } \\
\text { intervene where there are allegations of large } \\
\text { scale loss of human life or ethnic } \\
\text { cleansing. It should in this context seek } \\
\text { adequate verification of facts or conditions } \\
\text { on the ground that might support a military } \\
\text { intervention. } \\
\text { D. The Permanent Five members of the } \\
\text { Security Council should agree not to apply } \\
\text { their veto power, in matters where their vital } \\
\text { state interests are not involved, to obstruct } \\
\text { the passage of resolutions authorizing } \\
\text { military intervention for human protection } \\
\text { purposes for which there is otherwise } \\
\text { majority support. } \\
\text { E. If the Security Council rejects a proposal } \\
\text { or fails to deal with it in a reasonable time, } \\
\text { alternative options are: } \\
\text { I. consideration of the matter by the General } \\
\text { Assembly in Emergency Special Session }\end{array}$ \\
\hline
\end{tabular}




\begin{tabular}{|c|c|c|c|}
\hline & & & $\begin{array}{l}\text { under the "Uniting for Peace" procedure; and } \\
\text { II. action within area of jurisdiction by } \\
\text { regional or sub-regional organizations under } \\
\text { Chapter VIII of the Charter, subject to their } \\
\text { seeking subsequent authorization from the } \\
\text { Security Council. } \\
\text { F. The Security Council should take into } \\
\text { account in all its deliberations that, if it fails } \\
\text { to discharge its responsibility to protect in } \\
\text { conscience-shocking situations crying out for } \\
\text { action, concerned states may not rule out } \\
\text { other means to meet the gravity and urgency } \\
\text { of that situation - and that the stature and } \\
\text { credibility of the United Nations may suffer } \\
\text { thereby. }\end{array}$ \\
\hline Just Cause & $\begin{array}{l}\text { Secondly, a just cause is required, namely } \\
\text { that those who are attacked, should be } \\
\text { attacked because they deserve it on account } \\
\text { of some fault. Wherefore Augustine says } \\
\text { (Questions. in Hept., qu. x, super Jos.): "A } \\
\text { just war is wont to be described as one that } \\
\text { avenges wrongs, when a nation or state has } \\
\text { to be punished, for refusing to make amends } \\
\text { for the wrongs inflicted by its subjects, or to } \\
\text { restore what it has seized unjustly." }\end{array}$ & $\begin{array}{l}2309 \text { At one and the same time: } \\
\text { - the damage inflicted by the aggressor on the } \\
\text { nation or community of nations must be } \\
\text { lasting, grave, and certain; } \\
\text { - all other means of putting an end to it must } \\
\text { have been shown to be impractical or } \\
\text { ineffective; } \\
\text { - there must be serious prospects of success; } \\
\text { - the use of arms must not produce evils and } \\
\text { disorders graver than the evil to be } \\
\text { eliminated. The power of modem means of } \\
\text { destruction weighs very heavily in evaluating } \\
\text { this condition. } \\
\text { These are the traditional elements } \\
\text { enumerated in what is called the "just war" } \\
\text { doctrine. }\end{array}$ & $\begin{array}{l}\text { (1) The Just Cause Threshold } \\
\text { Military intervention for human protection } \\
\text { purposes is an exceptional and extraordinary } \\
\text { measure. To be warranted, there must be } \\
\text { serious and irreparable harm occurring to } \\
\text { human beings, or imminently likely to occur, } \\
\text { of the following kind: } \\
\text { A. large scale loss of life, actual or } \\
\text { apprehended, with genocidal intent or not, } \\
\text { which is the product either of deliberate state } \\
\text { action, or state neglect or inability to act, or a } \\
\text { failed state situation; or } \\
\text { B. large scale 'ethnic cleansing', actual or } \\
\text { apprehended, whether carried out by killing, } \\
\text { forced expulsion, acts of terror or rape. }\end{array}$ \\
\hline
\end{tabular}




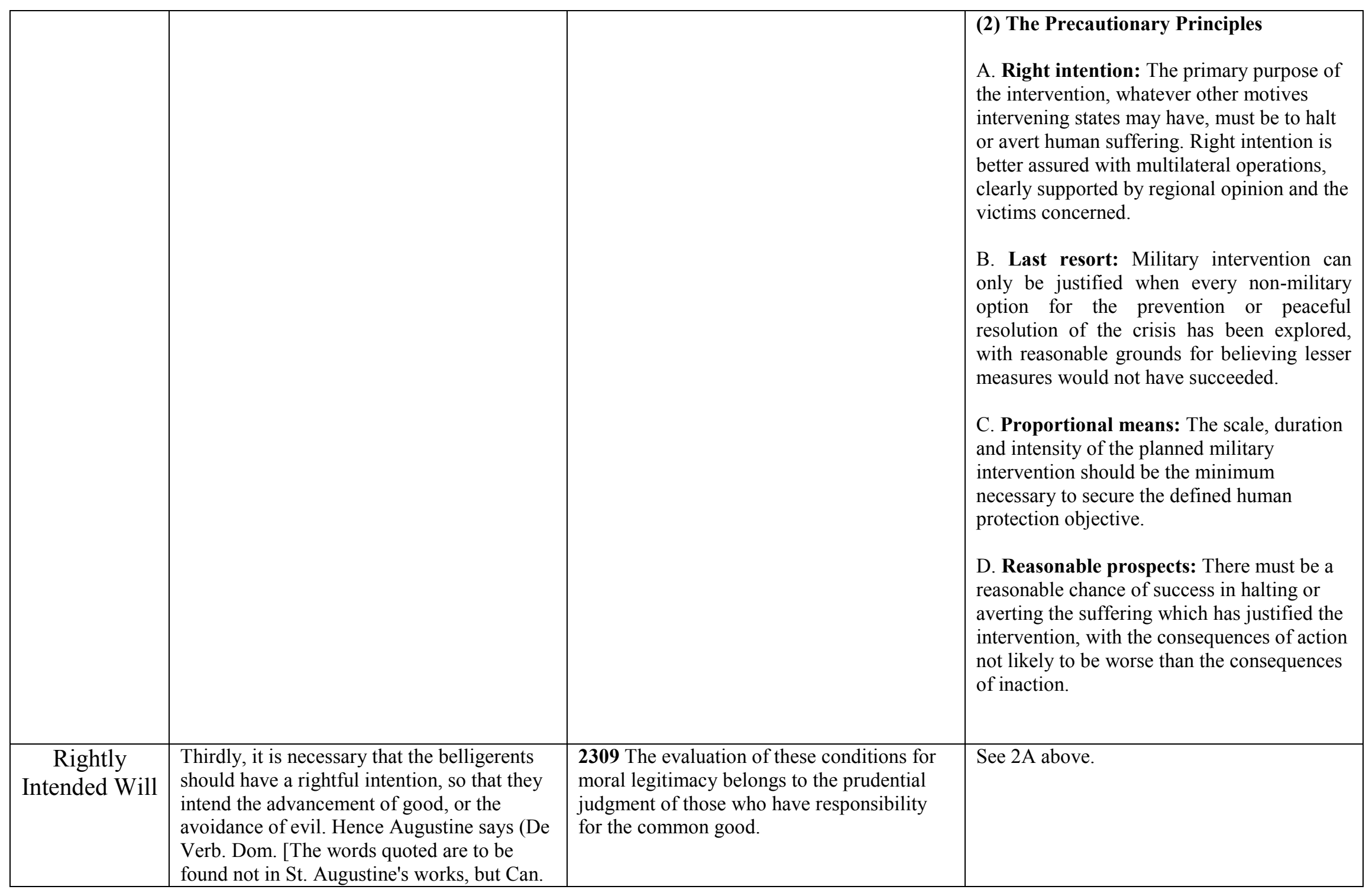




\begin{tabular}{|l|l|l|l|}
\hline & $\begin{array}{l}\text { Apud. Caus. xxiii, qu. 1]): "True religion } \\
\text { looks upon as peaceful those wars that are } \\
\text { waged not for motives of aggrandizement, or } \\
\text { cruelty, but with the object of securing peace, } \\
\text { of punishing evil-doers, and of uplifting the } \\
\text { good." For it may happen that the war is } \\
\text { declared by the legitimate authority, and for a } \\
\text { just cause, and yet be rendered unlawful } \\
\text { through a wicked intention. Hence } \\
\text { Augustine says (Contra Faust. xxii, 74): “The } \\
\text { passion for inflicting harm, the cruel thirst } \\
\text { for vengeance, an unpacific and relentless } \\
\text { spirit, the fever of revolt, the lust of power, } \\
\text { and such like things, all these are rightly } \\
\text { condemned in war." }\end{array}$ & \\
\hline
\end{tabular}

